\title{
Analysis of Industrial Markets for Low and Medium Btu Coal Gasification
}

July 30, 1979

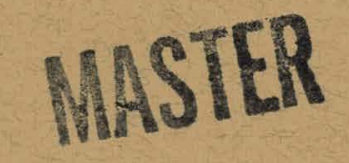

Prepared for:

U.S. Department of Energy

Assistant Secretary for Resource Applications

Contract No. ET-78-C-01-2625 


\section{DISCLAIMER}

This report was prepared as an account of work sponsored by an agency of the United States Government. Neither the United States Government nor any agency Thereof, nor any of their employees, makes any warranty, express or implied, or assumes any legal liability or responsibility for the accuracy, completeness, or usefulness of any information, apparatus, product, or process disclosed, or represents that its use would not infringe privately owned rights. Reference herein to any specific commercial product, process, or service by trade name, trademark, manufacturer, or otherwise does not necessarily constitute or imply its endorsement, recommendation, or favoring by the United States Government or any agency thereof. The views and opinions of authors expressed herein do not necessarily state or reflect those of the United States Government or any agency thereof. 


\section{DISCLAIMER}

Portions of this document may be illegible in electronic image products. Images are produced from the best available original document. 
Avallable from:

National Technical Infarmation Service (NTIS)

U.S. Department of Commerce

5285 Port Royal Road

Springfield, Virginia 22161

11.00

Price: Printed copy: $\$ 12.00$

Microfiche: $\$ 3.00$ 
1

\section{Analysis of Industrial Markets'for Low and Medium Btu Coal Gasification}

July 30,1979

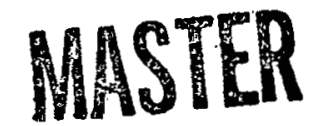

Prepared by:

Booz, Allen and Hamilton, Inc.

Bethesda, Md. 20014

Contract No. ET-78-C-01-2625

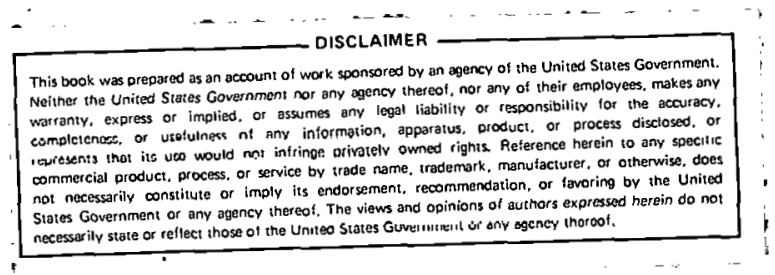

Prepared for:

U.S. Department of Energy

Assistant Secretary for Resource Applications

Washington, D.C. 20585

For sale by tho Supcrintendent of Domments, T.S. Govornmont Printing Ofieo 


\section{NOTICE}

This report was prepared as an account of work sponsored by the United States Government. Neither the United States nor the United States Department of Energy, nor any of their employees, makes any warranty, express or implied, or assumes any tegal liability or responsibility for the accuracy, completeness, or usefulness of any information, apparatus, product, or process disclosed, or represents that its use would not infringe privately owned rights. Reference herein to any specific commercial product, process, or service by trode name, mark, manufacturer, or otherwise, does not necessarily constitute or imply its endorsement, recommendation, or favoring by the United States Government or any agency thereof. The views and . opinions of authors expressed herein do not necessarily state or reflect those of the United States Government or any agency thereof. 
$\begin{array}{llllllllllllll}\text { T A B L E } & \text { O } & \text { F } & \text { C O } & \text { N T. } & \text { E N } & \text { T } & \text { S }\end{array}$

Page

Number

Executive Summary

I. Approach

$I-1$

II. Analysis of Industrial Energy Trends and

Previous Gasification Forecasts

$I I-1$

III. Assessment of Coal Gasification Technology and Economics

III-1

IV. Analysis of Present U.S. Industrial Applications of Low- and Medium-Btu Gasification

IV -1

V. Analysis of the Technically-Feasible Market for Low- and Medium-Btu Gasification

$\mathrm{V}-1$

VI. Identification of High Potential Regions for Coal Gasification

$\mathrm{VI}-1$

VII. Estimate of the Near-Term Market for Lowand Medium-Btu Gasification

VII-I

VIII. Government Role in Accelerating Industrial Markets for Low- and Medium-Btu Gasification

VIII-1

APPENDIX A - Participants in"Interviews $A-1$

APPENDIX B - The Gasifier Equipment Industry B-1

APPENDIX C - Fuel Supply Histories by state . C-l

APPENDIX D - Industrial Plant Energy Consumption Data

$D-1$

APPENDIX E - Summary Comments From Industry Interviews on Anticipated Gasifier Investments

E-1 
EXECUTIVE SUMMARY 
$>$

EXECUTIVE SUMMARY

Low- and medium-Btu gases (LBG and MBG) can be produced from coal with a variety of 13 existing and 25 emerging processes. Historical experience and previous studies indicate a large potential market for LBG and MBG coal gasification in the manufacturing industries for fuel and feedstocks. However, present use in the U.S. is limited, and industry has not been making substantial moves to invest in the technology.

Near-term (1979-1985) market activity for LBG and MBG is highly uncertain and is complicated by a myriad of pressures on industry for energy-related investments. To assist in planning its program to accelerate the commercialization Of LBG and MBG, the Department of Energy (DOE) contracted with BoOz, Allen \& Hamilton to characterize and forecast the 1985 industrial market for LBG and MBG coal gasification. (The study focuses on manufacturing markets and does not consider potential utility markets.) Based on information from interviews with current users, potential users and the gasifier equipment industry (Exhibit 1), the study draws five major conclusions:

There is a large technically feasible market potential in industry for commercially available equipment-exceeding 3 quadrillion Btu per year.

- Early adopters will be principally steel, chemical, and brick companies. Areas in and adjoining Pennsylvania, the Ohio and Tennessee River Valleys, East Texas, Wyoming, North Dakota, and California are attractive for early adoption. .

- With no additional Federal initiatives, industry commitments to LBG and MBG will moderately increase. The number of additional plants in or near operation by 1985 is estimated to be 10 to 20 LBG plants, 2 to 3 MBG single-user plants, and no MBG multiple-user plants.

- The major barriers to further market penetration are its lack of economic advantage, an absence of significant operating experience in the U.S., 
EXHIBIT 1

Summary List of Interview Participants

\begin{tabular}{|c|c|}
\hline urrent User Inter & \\
\hline $\begin{array}{l}\text { General Refractories } \\
\text { Glen-Gery Corporation } \\
\text { Hazleton Brick Company } \\
\text { National Lime \& Stone Company } \\
\text { Chemical Exchange Company } \\
\text { Dow Chemical Company } \\
\text { Gulf \& Western Titanium } \\
\text { Olin Chemical Corporation }\end{array}$ & $\begin{array}{l}\text { General Motors Corporation } \\
\text { Holston Defense Corporation } \\
\text { Howmet Aluminum } \\
\text { Land O'Lakes, Inc. } \\
\text { Pikeville Coal Gasification Project } \\
\text { U.S. Bureau of Mines } \\
\text { University of Minnesota }\end{array}$ \\
\hline $\begin{array}{l}\text { Potential User Interviews } \\
\text { Air Products \& Chemicals } \\
\text { Del Laboratories, Inc. } \\
\text { E. I. DuPont de Nemours } \\
\text { FMC Corporation } \\
\text { Mobay Chemical Corporation } \\
\text { Union Carbide } \\
\text { Armco, Inc. } \\
\text { Inland Steel Corporation } \\
\text { Kaiser Aluminum \& Chemical Co. } \\
\text { Kaiser Steel Company } \\
\text { Lukens Steel Company } \\
\text { U.S. Steel Corporation } \\
\text { Ashland Oil } \\
\text { Carter Oil Company } \\
\text { Shell Oil Company } \\
\text { Standard Oil Company of Indiana } \\
\text { Tennessee Gas Pipeline Company } \\
\text { Union: Oil Company } \\
\text { Jeannette Corporation } \\
\text { Midland Glass Co., Inc. } \\
\text { PPG Industries, Inc. } \\
\text { Johnson \& Johnson } \\
\text { St. Regis Paper Company }\end{array}$ & $\begin{array}{l}\text { American Can Company } \\
\text { American Seating Company } \\
\text { Cameron Iron Works } \\
\text { Haussy Metals } \\
\text { Ingalis Iron \& Steel } \\
\text { Mansfield Carbon Products } \\
\text { Midrex } \\
\text { Pascoe Steel } \\
\text { Ideal Basic } \\
\text { Martin-Marietta } \\
\text { Acme Brick Company } \\
\text { Brick Institute of Anerica } \\
\text { nthlone Industries } \\
\text { Ball Corporation } \\
\text { Brockway Glass Company } \\
\text { Chattanooga Glass Company } \\
\text { Ferro Corporation } \\
\text { Guardian Industries Corporation } \\
\text { Kerr Glass Manufacturing Company } \\
\text { Owens-Illinois, Inc. } \\
\text { Susquehanna Corporation. } \\
\text { Mead Paper Company } \\
\quad \text {. }\end{array}$ \\
\hline Equipment Industry Ir & \\
\hline $\begin{array}{l}\text { American Lurgi Corporation } \\
\text { Applied Technology Corporation } \\
\text { Combustion Engineering } \\
\text { Davy Powergas, Inc. } \\
\text { Gas Generation Associates }\end{array}$ & $\begin{array}{l}\text { Gilbert Associates, Inc. } \\
\text { Koppers Company, Inc. } \\
\text { Texaco Development Corporation } \\
\text { Wilputte Corporation }\end{array}$ \\
\hline
\end{tabular}


uncertainty on government environmental policy, and limited credible engineering data for retrofiting industrial plants.

- Within the context of generally accepted energy supply and price forecasts, selected government action can be a principal factor in accelerating market penetration.

Each major conclusion is discussed briefly in the fol-. lowing sections, after which several key implications for DOE planning are identified.

1. THE TECHNICALLY FEASIBLE MARKET POTENTIAL EXCEEDS

3 QUADRILLION BTU

There are three principal modes of operation for industrial coal gasification, as shown in Exhibit 2:

- Low-Btu (120 to $180 \mathrm{Btu} / \mathrm{scf})$ single-user plants, with energy output of typically 0.5-2.0 billion Btu/day

- Medium-Btu (250 to $350 \mathrm{Btu} / \mathrm{scf}$ ) single-user plants, with energy output of at least 7 to 10 billion Btu/day

- Medium-Btu multiple-user plants, with energy output of at least 30 billion Btu/day.

To estimate the size of the technically feasible market potential, an extensive analysis of major energy-consuming industries was conducted with respect to four screening criteria:

- Gas flame characteristics. Low-Btu gas exhibits lower flame temperature and requires higher flue volume than natural gas. MBG flame characteristics are similar to those of natural gas.

- Chemical composition. Low-Btu gas is unattractive for chemical feedstocks and certain heating applications due to high nitrogen content. MBG can be more attractive than natural gas as a feedstock and exhibits no technical limitations as a fuel.

- Plant size. Although the smallest commercially available gasifier unit produces about 0.2 billion Btu/day on anthracite, a reasonably feasible 
EXHIBIT 2

Expected Equipment Configurations for

Industrial LBG and MBG Applications

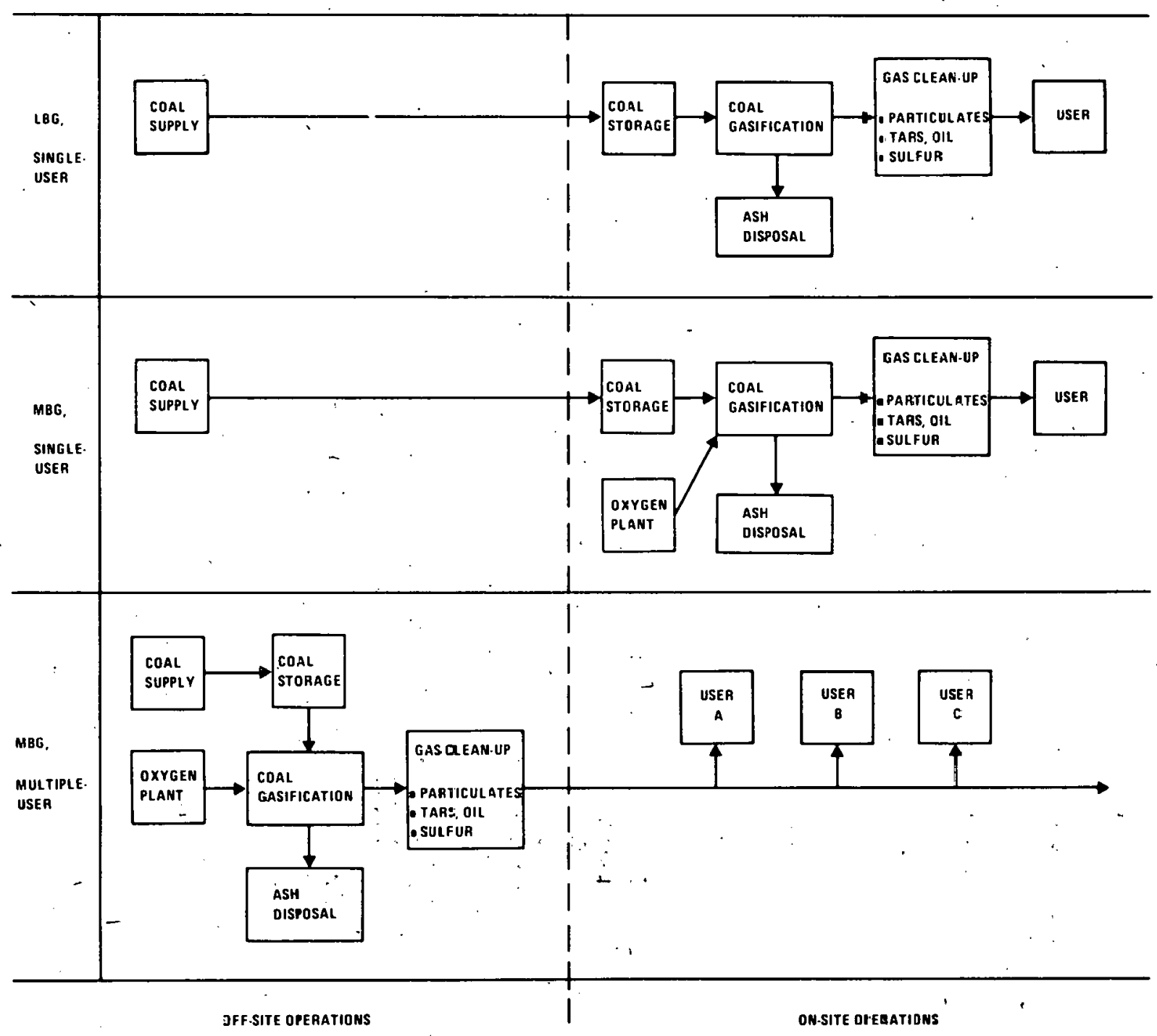


application should demand. 1 to 3 billion Btu/day for LBG. For single-user MBG plants, feasible demand should be at least 7 to 10 billion Btu/day, due to substantial economies of scale on. the attendant oxygen plants.

- Plant load factor. End-use industrial plants with highly cyclical energy demands are usually poor candidates for LBG and MBG.

Results of the screening analysis (Exhibit 3) indicate the technically feasible market potential to exceed three quads. By type of gasifier, estimates of the technically feasible market are as follows (not additive):

- At least 3,500 LBG single-user plants, which could represent about 1.2 quads

- At least 550 MBG single-user plants, which could represent about 1.6 quads

- I At least 300 MBG multiple-user plants, which could represent about 2.9 quads.

For DOE, the implication of these findings is that substantial potential exists for national benefit. To help focus the DOE program, and to provide an estimate of expected market, subsequent sections of the analysis discuss conclusions on early adopters, anticipated market response by 1985, and options for Federal action.

2. THE EARLY ADOPTERS FOR LBG AND MBG ARE IN SEVERAL

IDENTIFIABLE REGIONS AND INDUSTRIES

Economic and strategic conditions vary to a wide degree by region and industry, each of which is discussed in the two following sections.

(1) Five Areas of the U.S. Are Attractive on a Relative Basis for Reasons of Economics, Fuel Supply Security, and special Institutional Circumstances

Coal gasification has a potential for economic attractiveness in industrial applications where coal prices are low, relative to fuel oil and natural gas prices. A detailed survey of actual industrial fuel 
EXHIBIT 3

Summary Screening Analysis For Feasibility

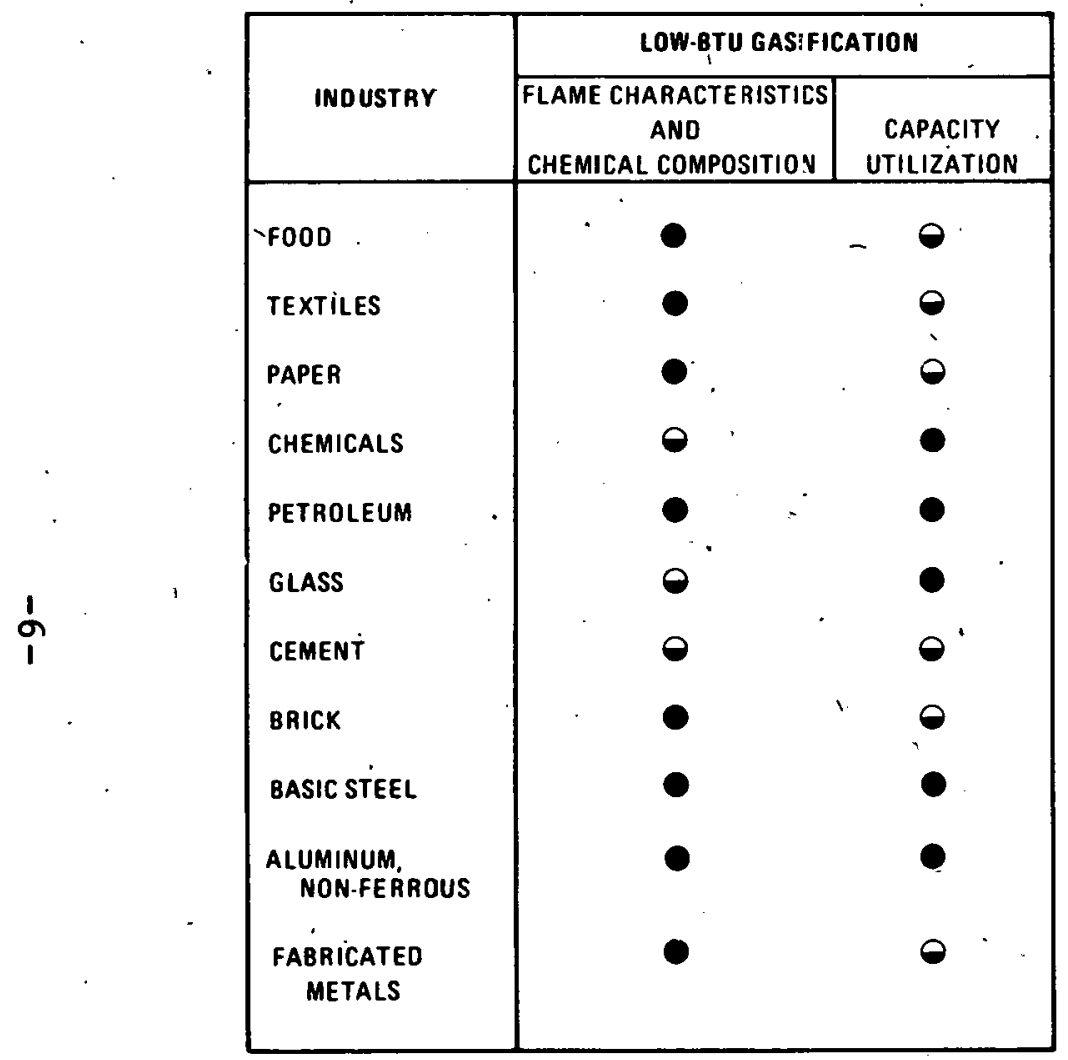

\begin{tabular}{|c|c|c|}
\hline \multicolumn{3}{|c|}{ MEOIUM-BTU GASIFICATION } \\
\hline $\begin{array}{l}\text { FLAME CH } \\
\text { CHEMICAL }\end{array}$ & $\begin{array}{l}\text { IARACTERISTICS } \\
\text { AND } \\
\text { L COMPOSITION }\end{array}$ & $\begin{array}{c}\text { CAPACITY } \\
\text { UTILIZATION } \\
\text { (SINGLE-USER ONLY) }\end{array}$ \\
\hline 1 & $\begin{array}{l}0 \\
\bullet \\
0 \\
0 \\
0 \\
0 \\
0 \\
0 \\
0 \\
\bullet\end{array}$ & $\begin{array}{r}0 \\
0 \\
0 \\
0 \\
-0 \\
0 \\
0 \\
0 \\
0 \\
0 \\
0\end{array}$ \\
\hline
\end{tabular}

\begin{tabular}{|c|c|c|}
\hline \multicolumn{3}{|c|}{ SUMMARY FEASIBILITY } \\
\hline LJW.BTU & $\begin{array}{c}\text { MEOIUM.BTU } \\
\text { SINGLE.USER }\end{array}$ & $\begin{array}{c}\text { MEDIUM.BTU. } \\
\text { MULTIPLE.USERS }\end{array}$ \\
\hline$\bullet$ & 0 & $\bullet$ \\
$\bullet$ & 0 & $\bullet$ \\
$\ominus$ & $\bullet$ & $\bullet$ \\
$\bullet$ & $\bullet$ & $\bullet$ \\
$\bullet$ & $\bullet$ & $\bullet$ \\
$\ominus$ & 0 & $\bullet$ \\
$\ominus$ & $\bullet$ & $\bullet$ \\
$\bullet$ & 0 & $\bullet$ \\
$\bullet$ & $\bullet$ & $\bullet$ \\
$\bullet$ & $\bullet$ & $\bullet$ \\
$\bullet$ & $\bullet$ & $\bullet$ \\
\hline
\end{tabular}

KEY: : INOUSTRY MEETS CRITERION

: INDUSTRY MEETS CRITERION IN PART

O: INDUSTRY.DOES NOT MEET CAITERICN 
prices by location was conducted for the study in February 1979. Prices were projected to 1985, using three key assumptions (constant dollars):

- Oil prices increase at two percent annually Natural gas prices are nearly equal to oil prices by 1985

- Coal prices remain constant in real dollars.

The most favorable areas for economic potentialon a relative basis across the U. S.-are depicted in Exhibit 4, which shows the ratios of projected oil to coal prices:

Wyoming and adjacent states. Best economic conditions, relative to other regions of the U. S.

- North Dakota. Good economics on lignite:

- East Texas and adjacent states: Good economics on lignite.

- Tennessee and Ohio River Valleys. Potentially attractive economics on bituminous and sub-bituminous.

- Eastern Pennsylvania and adjacent states. Attractive conditions for LBG on anthracite.

In addition to relative economic conditions, a history of fuel supply problems and special institutional circumstances indicate regional market opportunity for LBG and MBG. Three key supply-related factors were researched for the study, as shown in Exhibit 5:

- Actual natural gas curtailments, 1975-1978

- Shortages of alternate fuels, 1975-1978

- Special problems perceived by industry to be related to energy conditions, such as frozen rivers, level of contracted interruptions; etc. 
EXHIBIT 4

Economically Attractive Regions for LBG and MBG

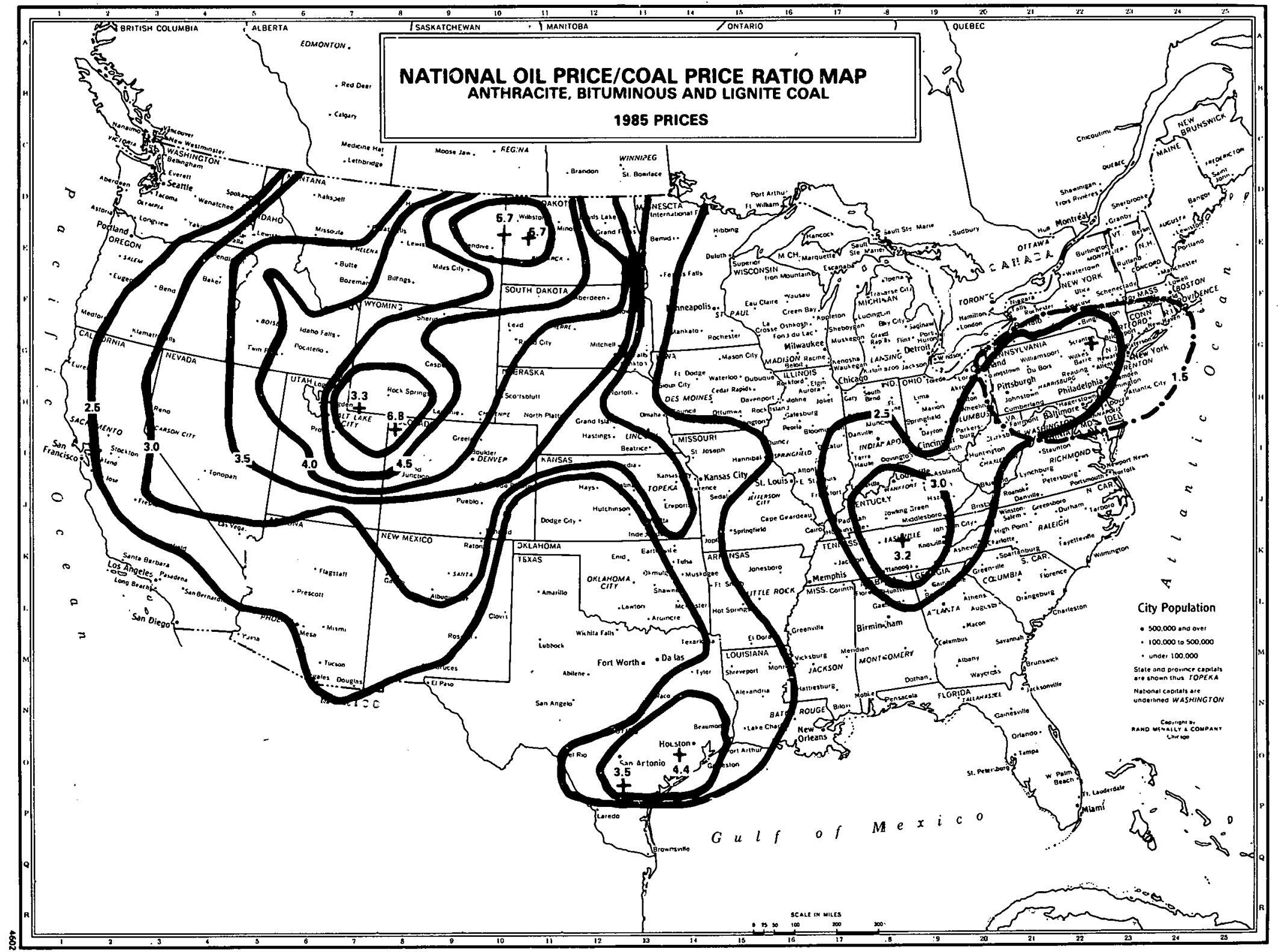


EXHIBIT 5

Summary Analysis: Impact of 1975-1978

Fuel Shortages on Industry by state

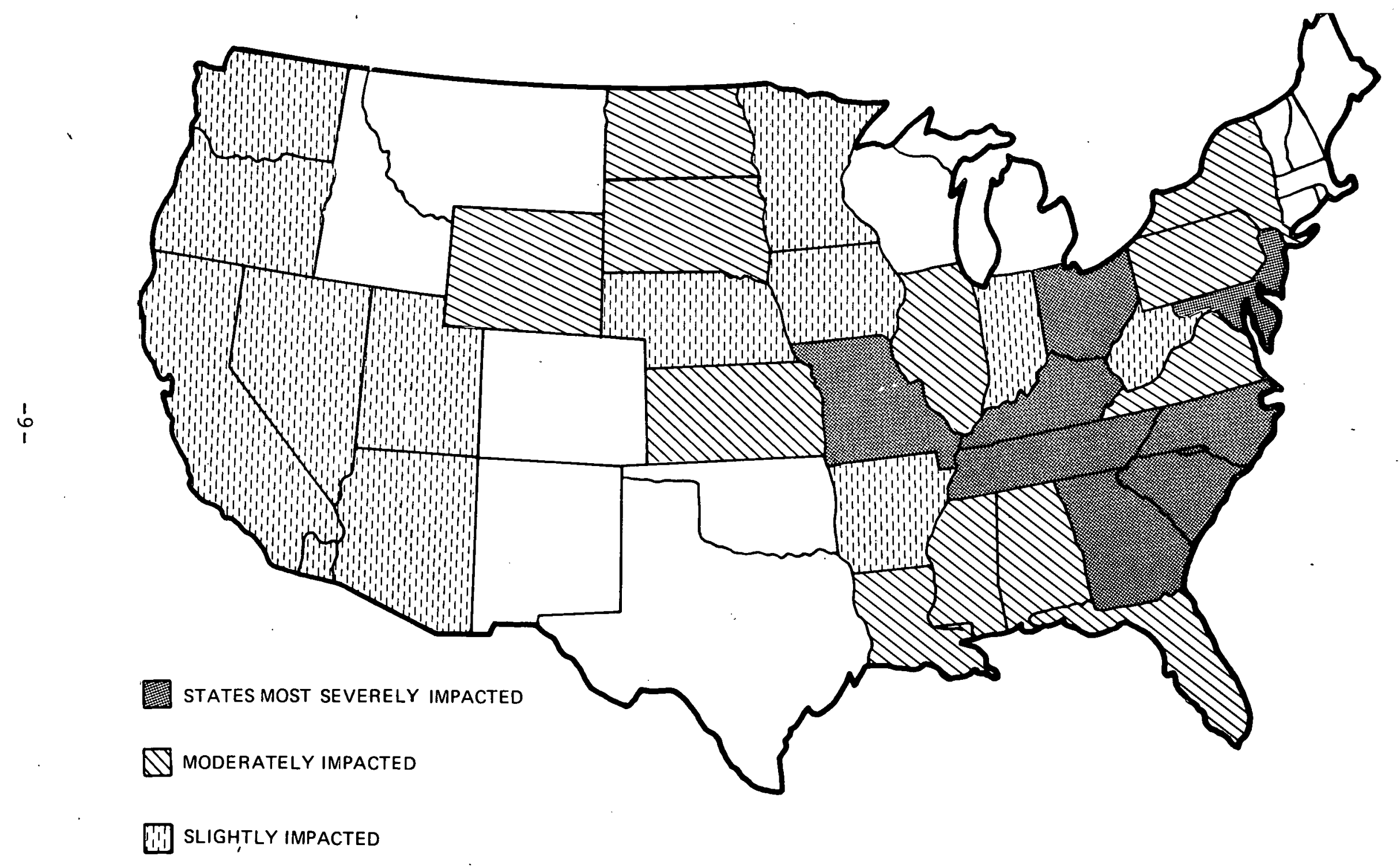


In total, 14 states were identified as key targets for initial commercialization efforts, as shown in Exhibit 6. States immediately adjacent to the 14 target states may also have high potential conditions. The final analysis to identify attractive areas for LBG and MBG commercialization was based on crossreferencing the economic attractiveness and fuel supply problem areas. In addition, California was selected due to environmental restrictions on conventional energy development.

(2) Early Adopters Are Likely To Be Concentrated in the Steel, Chemical, and Brick Industries

From industry interviews with equipment manufacturers, existing domestic users, and a large number of potential users, ten major factors were cited as characteristics of early adopter industries:

- Clear technical féasibility on gas use

- Adequate demand and high load factor

- Low-plant retrofit requirements

- Need for gaseous fuel

- Sensitivity to natural gas curtailments

- High oil and gas costs as a percent of sales

- Current coal utilization

- Ownership of captive coal supplies

- Location in relatively attractive areas

- Familiarity with gasifier technology.

Based on a detailed examination of each industry, early adopter candidates were determined to be concentrated in a few industries:

- LBG early adopter characteristics are prevalent in the brick and steel industries. Additional opportunity may lie in the aluminum, chemical, ceramic/tile, and refractory industries (Exhibit 7).

MBG early adopter rharacteristirs are prevalent in the chemical, steel and, possibly, the aluminum industries (Exhibit 8). 
EXHIBIT 6

Target States for Coal Gasification Commercialization

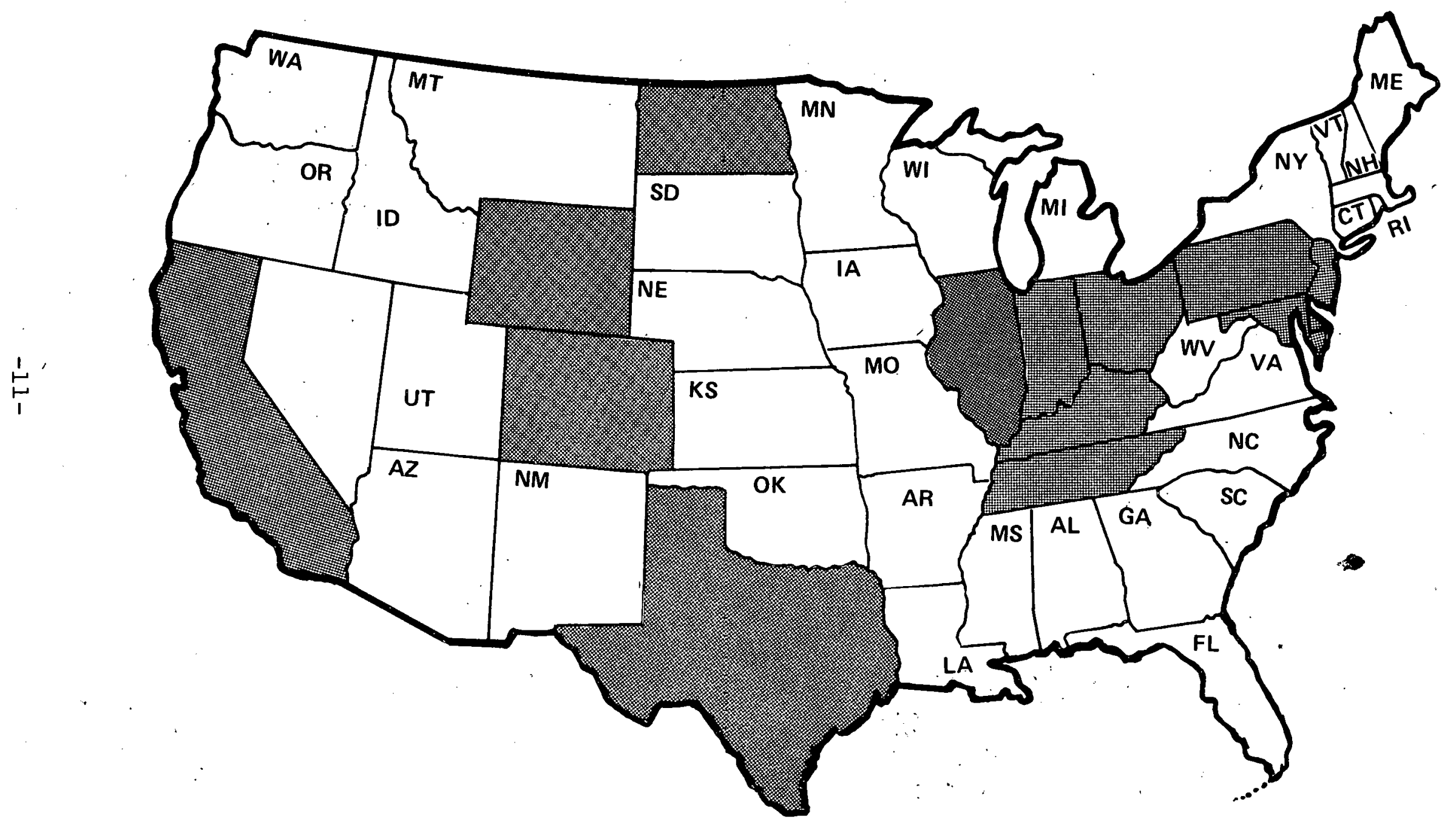


EXHIBIT 7

Industry Screening Summary: Low-Btu Gasification

\begin{tabular}{|c|c|c|c|c|c|c|c|c|c|c|c|c|}
\hline \multirow{2}{*}{$\because$ INOUSTAY } & \multicolumn{2}{|c|}{$\begin{array}{c}\text { FEASIBILITY } \\
\text { CRIERIA }\end{array}$} & \multicolumn{4}{|c|}{$\begin{array}{c}\text { B.ASIC } \\
\text { ATTRACTIVENESS }\end{array}$} & \multicolumn{5}{|c|}{ EARLY POOPTER CHARACTERISTICS } & \multirow[b]{2}{*}{$\begin{array}{l}\text { EARLY } \\
\text { ADOPTEAS } \\
\end{array}$} \\
\hline & $\begin{array}{l}\text { FLAME \& } \\
\text { CHEMICAL }\end{array}$ & $\begin{array}{l}\text { CAPACITY } \& \\
\text { LOAO FACTOR }\end{array}$ & $\begin{array}{l}\text { EASE OF } \\
\text { RET ROFIT }\end{array}$ & \multicolumn{2}{|c|}{ GAS rYPE } & $\begin{array}{l}\text { SENSITIVE TO } \\
\text { GAS SUPPLY }\end{array}$ & $\begin{array}{l}\text { HIGH OIL ANO } \\
\text { GAS COST }\end{array}$ & $\begin{array}{l}\text { CURRENT } \\
\text { COAL USER }\end{array}$ & $\begin{array}{l}\text { CAPTIVE } \\
\text { COAL SUPPLY }\end{array}$ & $\begin{array}{l}\text { HIGH POTENTIAL } \\
\text { LOCATIONS }\end{array}$ & $\begin{array}{c}\text { FAMILIARITY } \\
\text { WITH TECHNOLOGY } \\
\end{array}$ & \\
\hline$F 00 D^{\circ}$ & 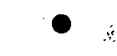 & $\theta$ & $\theta$ & 0 & $\therefore$ & $\sigma$ & 0 & $\theta$ & 0 & $0:$ & $\dot{0}$ & 00 \\
\hline TEXTILES : : & $\bullet$ & $\ominus$ & 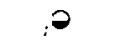 & O & - & $\bullet$ & 0 & $\ominus$ & 0 & 0 & 0 & 0 \\
\hline PAPER & - : & $\ominus$ & $\ominus$ & 0 & o & a & $\odot$ & $\bullet$ & $\theta$ & 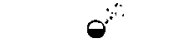 & $\dot{\theta}$ & 0 \\
\hline CHEMICALS & $\ominus$ & - & 0 & - & 0 & $\Leftrightarrow$ & $\ominus$ & $\bullet$ & $\theta$ & $\bullet$ & - & $\theta$ \\
\hline PET́ROLEUM & $\bullet$ & • & $\partial$ & 0 & $\ominus$ & $\mathrm{C}$ & 0 & $\theta$ & - & - & 0 & 0 \\
\hline GLASS & $\ominus$ & - & $\partial$ & 0 & $\bullet$ & $\theta$ & - & 0 & 0 & $\ominus$ & $\ominus$ & $\ominus$ \\
\hline CEMENT & $\bullet$ & $\ominus$ & - & $\bullet$ & 0 & $c$ & $\bullet$ & $\bullet$ & $\theta$ & $\ominus$ & - & 0 \\
\hline BAICK & • & $\bullet$ & - & $\bullet$ & 0 & - & - & 0 & 0 & $\ominus$ & - & - \\
\hline CERAMICS/TILE & - & $\ominus$ & $\bullet$ & O & $\bullet$ & -0 & $\bullet$ & 0 & $\stackrel{c}{:}$ & 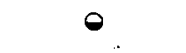 & $\bullet$ & $\ominus$. \\
\hline REFRACTORIES & - & - & $\ominus$ & $\theta$ & $\bullet$ & - & $\bullet$ & $\bullet$ & $c$ & $\ominus$ & - & $\bullet$ \\
\hline STEEL & $\bullet$ & - & - & $\ominus$ & - & $\theta$ & ○ & $\bullet$ & - & $\bullet$ & $\bullet$ & - \\
\hline $\begin{array}{l}\text { AL \& OTHER } \\
\text { NONFERROUS }\end{array}$ & $\bullet$ & $\bullet$ & $\ominus$ & $\ominus$ & $\bullet$ & $\Theta$ & 0 & 0 & $\theta$ & $\ominus$ & - & $\ominus$ \\
\hline $\begin{array}{l}\text { METAL } \\
\text { FABRICATICN. }\end{array}$ & - & O. & $\bullet$ & $\diamond$ & $\bullet$ & $\therefore \theta$ & 0 & O & $\ominus$ &. & $\bullet$ & 0 \\
\hline
\end{tabular}

KEY: - : INDUSTRY MEETS CF TERION

: INOUSTAY MEETS CFTERION IN PAFT
INDUSTAY DOES NOT MEET CRITERIJN 
EXHIBIT 8

Industry Screening Summary

Medium-Btu Gasification: Single-User Plants

\begin{tabular}{|c|c|c|c|c|c|c|c|c|c|c|c|}
\hline \multirow{2}{*}{ INDUSTRY } & \multicolumn{2}{|c|}{$\begin{array}{l}\text { FEASIBILITY } \\
\text { CRITERIA }\end{array}$} & \multicolumn{2}{|c|}{$\begin{array}{c}\text { BASIC } \\
\text { ATTRACTIVENESS }\end{array}$} & \multicolumn{6}{|c|}{ EARLY ADOPTER CHARACTERISTICS } & \multirow{2}{*}{$\begin{array}{l}\text { EARLY } \\
\text { ADOPTERS }\end{array}$} \\
\hline & $\begin{array}{c}\text { CHEMICAL \& } \\
\text { FLAME }\end{array}$ & $\begin{array}{l}\text { CAPACITY } \\
\text { UTILIZATION }\end{array}$ & $\begin{array}{l}\text { NEED FOR } \\
\text { CLEAN GAS }\end{array}$ & $\begin{array}{l}\text { SENSITIVE TO } \\
\text { GAS SUPPLY }\end{array}$ & $\begin{array}{l}\text { HIGH GASI } \\
\text { OIL COST }\end{array}$ & $\begin{array}{l}\text { CURRENT } \\
\text { COAL USER }\end{array}$ & $\begin{array}{c}\text { CAPTIVE } \\
\text { COAL SUPPLY }\end{array}$ & $\begin{array}{c}\text { FAMILIARITY } \\
\text { WITH TECHNOLOGY }\end{array}$ & $\begin{array}{l}\text { ENERGY } \\
\text { INNOVATOR }\end{array}$ & $\begin{array}{l}\text { HIGH POTENTIAL } \\
\text { LOCATIONS }\end{array}$ & \\
\hline FOOD & $\bullet$ & O & $\bullet$ & $\bullet$ & 0 & $\ominus$ & 0 & 0 & 0 & 0 & 0 \\
\hline TEXTILES & - & 0 & - & - & 0 & $\theta$ & 0 & 0 & 0 & 0 & 0 \\
\hline PAPER & - & $\ominus$ & 0 & 0 & $\ominus$ & - & $\theta$ & 0 & $\odot$ & $\ominus$ & 0 \\
\hline CHEMICALS & - & $\bullet$ & - & $\odot$ & $\theta$ & - & $\odot$ & - & - & - & - \\
\hline PETROLEUM & - & - & $\ominus$ & 0 & 0 & $\ominus$ & - & $\theta$ & - & - & 0 \\
\hline GLASS & - & 0 & $\ominus$ & $\theta$ & - & 0 & 0 & $\theta$ & 0 & $\theta$ & 0 \\
\hline CEMENT & $\bullet$ & $\ominus$ & 0 & .0 & - & $\bullet$ & $\theta$ & e & $\theta$ & $\ominus$ & 0 \\
\hline BRICK & - & 0 & $\ominus$ & - & - & 0 & 0 & 0 & 0 & $\theta$ & 0 \\
\hline BASIC STEEL & $\bullet$ & - & - & $\ominus$ & $\theta$ & $\bullet$ & - & - & 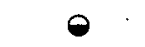 & - & - \\
\hline $\begin{array}{l}\text { ALUMINUM, } \\
\text { NON-FERROUS }\end{array}$ & - & $\ominus$ & - & - & 0 & 0 & $\ominus$ & $\ominus$ & - & 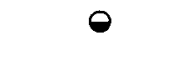 & $\bullet$ \\
\hline $\begin{array}{l}\text { FABRICATED } \\
\text { METALS }\end{array}$ & $\bullet$ & $\ominus$ & $\bullet$ & $\ominus$ & 0 & 0 & $\ominus$ & $\ominus$ & $\ominus$ & $\ominus$ & 0 \\
\hline
\end{tabular}

KEY: : INDUSTRY MEETS CAITERION

$\bigcirc:$ INDUSTRY MEETS CAITERION IN PART

O: INOUSTRY DOES NOT MEET CRITERION 
3. THE NUMBER OF ADDITIONAL LBG AND MBG PLANTS FORECAST TO BE IN OR NEAR OPERATION BY 19.5 IS LESS THAN 2.5 PLAANTS

Analysis of the interview findings to estimate the 1985 market was conducted on the basis of informed judgment, after detailed consideration of three key factors:

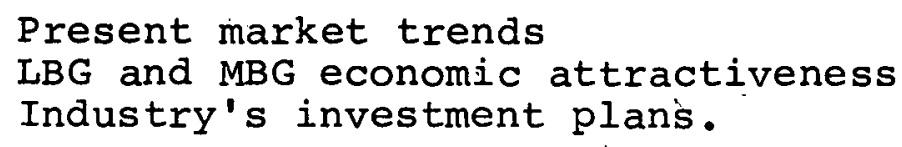

Conglusione on thcac factors afe discussed briefly in the following sections.

(1) Foreign Activity Dominates the World Market; U.S. Projects Are Unique Situatinns Althnilgh There Ts Increasing Activity

Based on interviews and literature citations, there are at least 113 foreign coal gasification projects in 'at least 29 different countries. In the U. S., there are. at least 21 gasification projects in various stages, as shown in Exhibit 9:

- Six plants in operation

- Five plants in start-up

- Four plants in or near construction

- Six plants in serious plánning

However, only three U.S. projects are standard commercial investments relevant to future industrial markets:

- Two LBG plants were recently built, for fuel supply security.

- One large MBG project is in planning for the late $1980 \mathrm{~s}$.

The majority of projects have unique considerations and fall into one of several categories:

- Uld or reactivated plants from the '1940s and $1950 \mathrm{~s}$

- Coke-fed MBG plants for carbon monoxide production

- Government cost-shared projects 
EXHIBIT 9

Summary of Industrial Gasification Projects Spring 1979

,

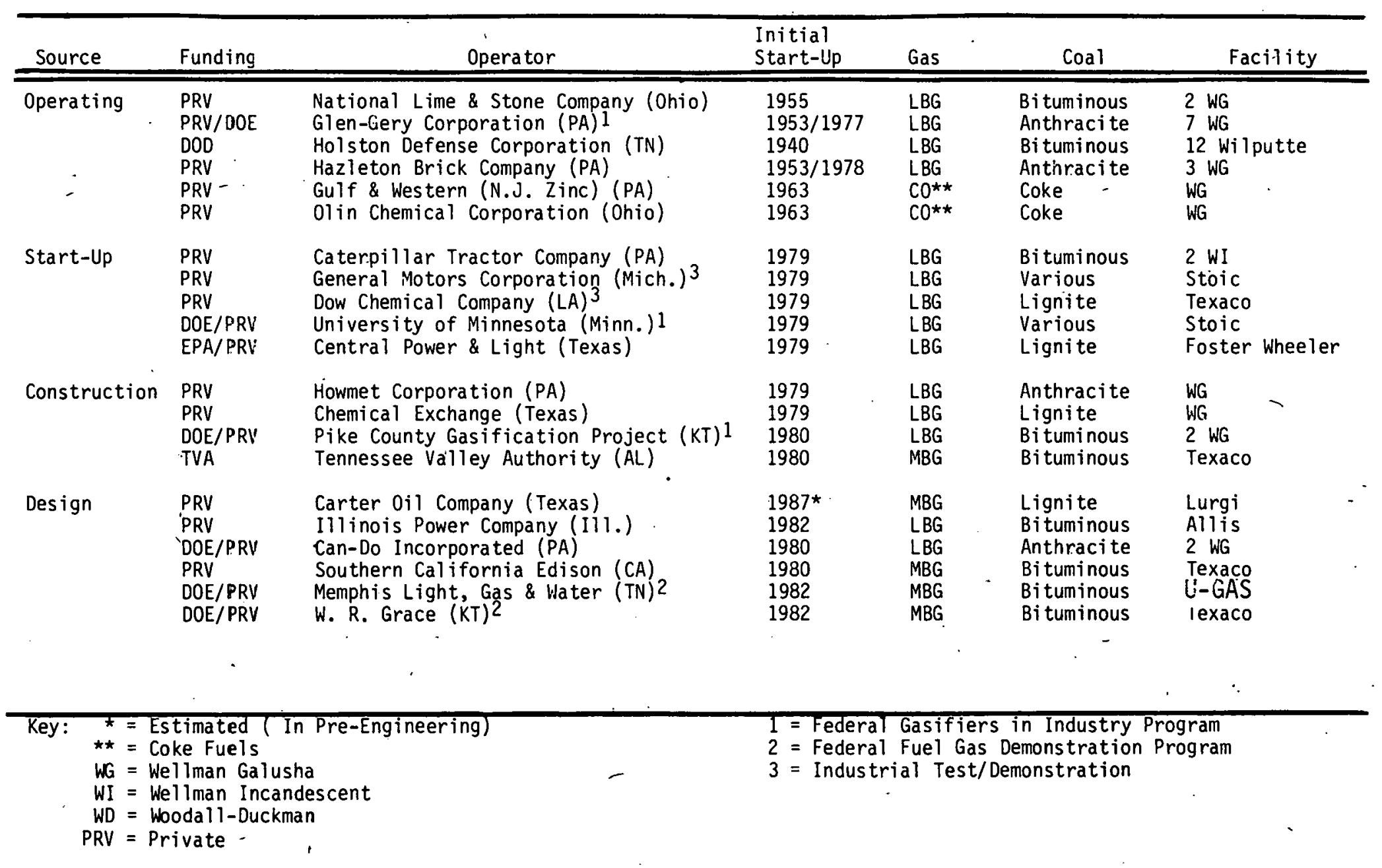




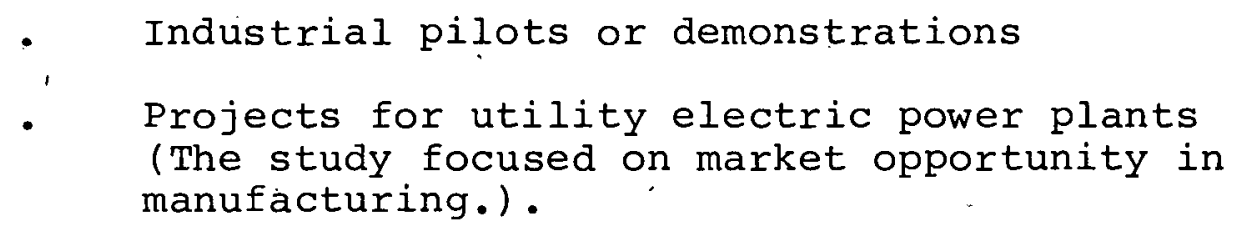

(2) Economic Attractiveness Is Highly Situation-Specific; Gas Costs Range From $\$ 2.70$ to $\$ 9.60$ Per Million Btu

Detailed analysis of LBG and MBG economics was based on actual supplier quotes for equipment, operating costs, and coal. Three analytical cases were developed to assess a range of equipment configurations and financing, as shown in Exhibit 10:

- The most attractive configurations are LBG hot raw gas-which has limited opportunity due to environmental constraints-and MBG multiple-user plants when utility financed. Base case estimates are:

$$
\begin{aligned}
& \text { - LBG hot raw gas-\$3.53/MMBtu } \\
& \text { - } \quad \text { MBG utility financed-\$3.96/MMBtu }
\end{aligned}
$$

- The least attractive configuration is the MBG single-user plant, principally due to poor economies of scale. The'base case estimate is $\$ 6.28 /$ MMBtu.

Generally accepted fuel price forecasts indicate economic attractiveness by the late $1980 \mathrm{~s}$ and early 1990s, as shown in Exhibit 11. However, as also shown in the exhibit, actual average fuel oil and natural gas prices are increasing more rapidly than anticipated; and initial economic advantages might be realized well before 1985, particularly in the situations which offer lower gasification costs than the Base Case figures and higher conventional fuel prices than average.

Results' of the economic analysis were utilized to probe industry investment intentions, as discussed in the next section. 
EXHIBIT 10

Summary Results: LBG/MBG. Economics

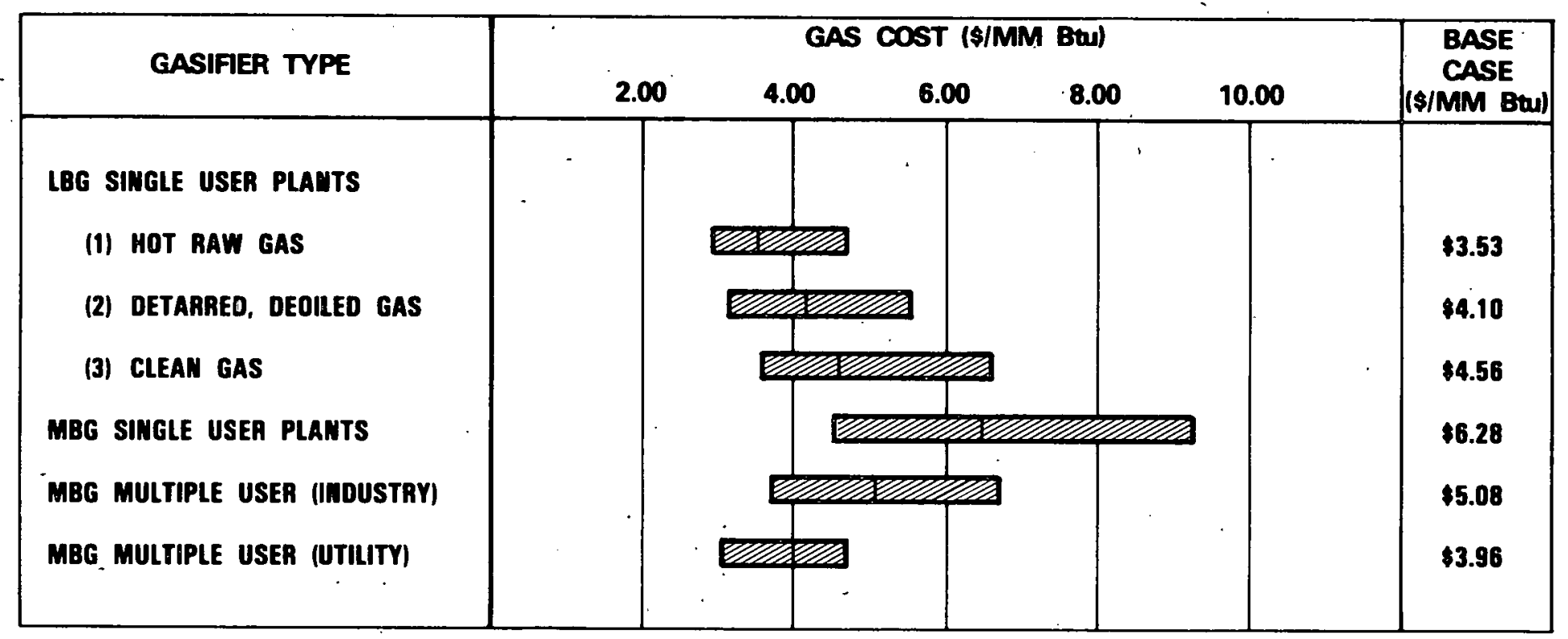

KEY:

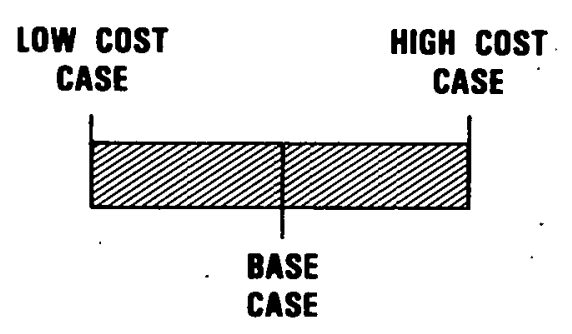


EXHIBIT 11

Cost of Various Coal Gasification

Configurations Vs. Conventional Industrial Fuel Prices (1978 Dollars)

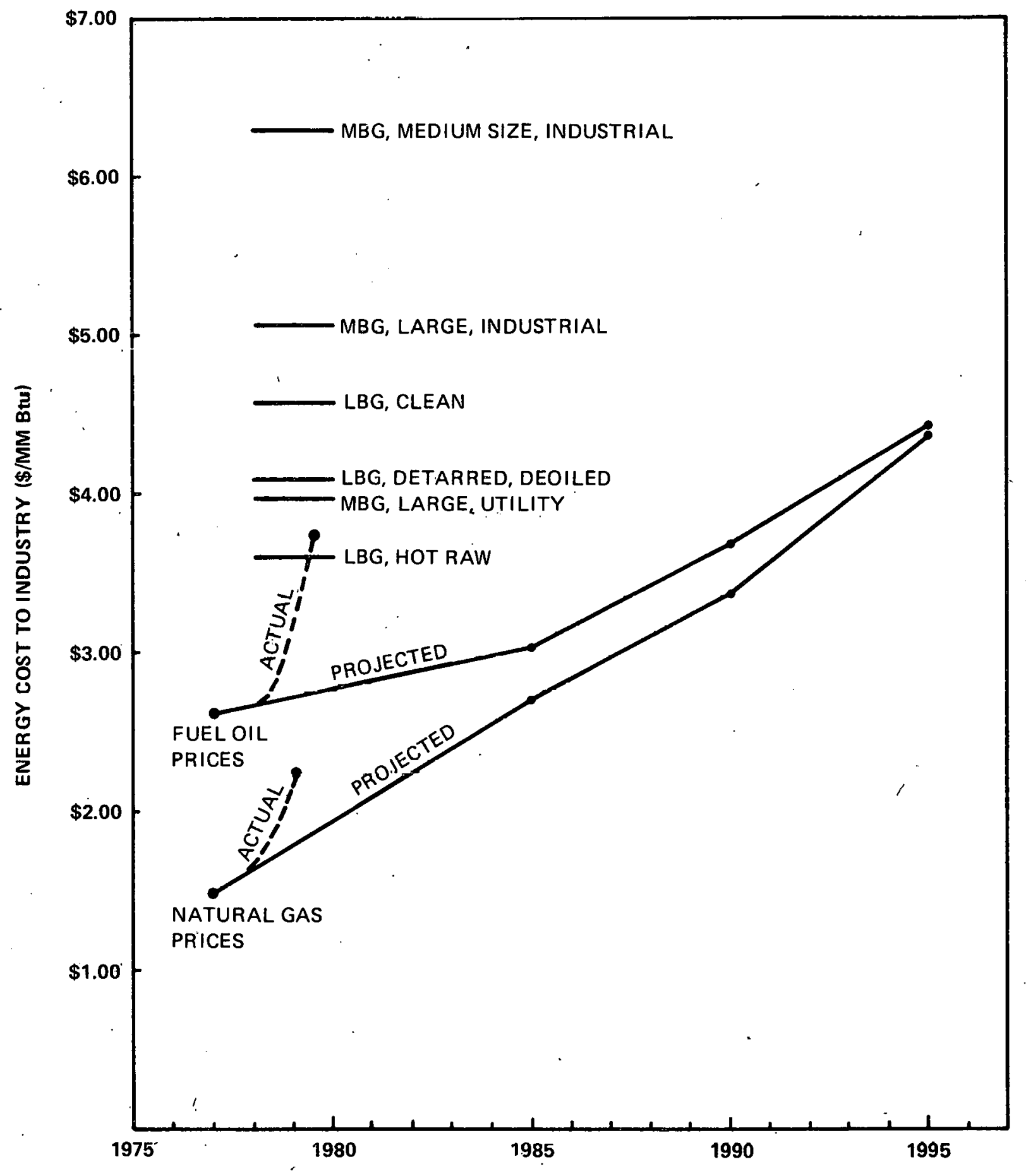

SOURCES:

-ENERGY SUPPLY AND DEMAND IN THE MIDTERM: 1985, 1990, 1995 (DRAFT), ENERGY INFORMATION ADMINISTRATION, DOE, 1979.

- PLATT'S OILGRAM, MAY 29, 1979, FOR ACTUAL OIL PRICES

- INDUSTRY INTERVIEWS FOR ACTUAL NATURAL GAS PRICES

- CHAPTER III, BASE CASE ESTIMATES OF LBG/MBG COSTS

$$
-18-
$$


(3) Industry Is Knowledgeable on Gasification

Technology, Is Convinced That LBG and MBG Are Not Economic Today, and Will Take a wait-and-See

Attitude Until Government Policies Are Resolved

Based on a comparison of interviews conducted for the study and other interviews conducted with industry since the mid 1970s, four factors indicate that industry is recovering from energy problems experienced since 1973-19,74:

- Substantial efficiency improvements have been made and are continuing.

- Fuel use flexibility has been built into all critical plants, with rapid change-over capabilities to burn fuel oils, natural gas, propane, and (in some cases) waste products.

- Technology àternatives have been analyzed, and preliminary choices made, for potential future investments.

- Most companies have prepared energy use strategies, have a senior engineer. or manager in charge of energy use, and actively track their energy situations:-

Most large companies were found to be knowledgeable on LBG and MBG gasification technology. The majority of corporate studies were conducted in the 1976-1977 period. Almost universally, industry is convinced on two points:

- LBG and MBG do not todáy provide a clear economic advantage over conventional fuels without additional government incentives.

- Early adopters face high risks due to lack of operating experience, uncertainty on actual equipment costs, lack of credible data on plant retrofit requirements (for LBG), and uncertainties on government policies regarding energy pricing and environmental restrictions. 
For these reasons, potential individual industrial users are holding back commitments. For MBG multipleuser plants, there is widespread interest in industry, but no indications that projects will be undertaken on a commercial basis and cperating until the late 1980s. For single-user plants, investment is anticipated in two categories:

- Small test gasifiers by large innovator firms (e.g., Generill Motor's current project)

- A few full-scale gasifiers to solve isolated supply prnhlems and/r.r in highly at.t.rartive economic circumstance: (e.g., the Caterpillar and Howmet projects).

(4) Industrial Investment Is Forecast To Result in Ten to Twenty LBG Plants, Two to Three MBG Single-User Plants, and No $\mathrm{MBG}$ Multiple-User Plants in or Near Operation by 1985

Based on the preceding assessment of present market trends, LBG and MBG economics, and industry's investment intentions, Booz, Allen's estimate of the market by 1985 - is as follows:

\footnotetext{
- Ten to twenty LBG single-user plants in or near operation by 1985:

- Hot raw gao-Brick, coment, and metal Forying/smel ling industries

- Clean gas-Metal treating, refractories, and possibly glass industries

Two to three MBG single-user plants in or near operation by 1985 :

- Best potential-steel and chemicals industries

- Other potential-Aluminum, glass, metal fabrication, and refining industries

No MBG multiple-user plants in or near operation by 1985, due to two key constrain'ts:

- Long project lead times indioate that the late $1980 \mathrm{~s}$ is the earliest feasible target for operation.
} 


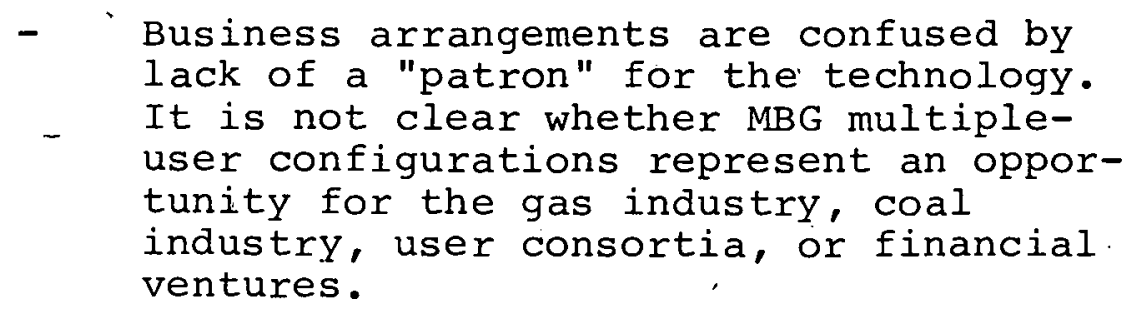

The implication of these estimates is that LBG and MBG are unlikely to represent a substantial energy source in the industrial sector by the mid $1980 \mathrm{~s}$ unless several key barriers are overcome, as discussed in the following section.

4. ALTHOUGH EACH PLANT DECISION ENVIRONMENT IS UNIQUE, THERE ARE FOUR PRINCIFAL BARRIERS TO MORE RAPID MARKET PENETRATION OF LBG AND MBG IN INDUSTRY

Each company interviewed for the study - and which had considered, and rejected or deferred, LBG/MBG investmentidentified situation-specific reasons for their respective decisions. However, there are four factors which influenced nearly all negative decisions to date:

- Economics-Lack of current economic advantage and lack of confidence in long-term benefit to investors under present conditions

- Experience-Lack of operating experience in U.S. industrial environments

- Government policy uncertainty-Perceived lack of resolution on environmental policy regarding coal gasifiers and alternatives

- Specific data-Lack of credible engineering data on the complexity and cost of industrial plant retrofit requirements.

While these problems constrain the near-term opportunity for investment in coal gasification, it is not insignificant to note that a large fraction of industry executives interviewed for the study consider coal gasification-and other technologies such as coal. liquefaction and fluidized-bed combustion-to be inevitable solutions to U.S. energy problems. 
5. UNDER GENERALLY ACCEPTED FORECASTS OF ENERGY PRICES AND SUPPLY, FEDERAL INITIATIVES WILL BE THE PRINCIPAL FACTOR TO ACCELERATE MARKET PENETRATION OF LBG AND MBG

The impact of existing Federal, initiatives was a key issue in industry interviews, and has been considered in the study's conclusions on market activity by 1985:

Impact of previous DOE programs to date is negligible due to delays and complexities in cost-shared projects.

- Impact by 1985 of the Powerplant and Industrial Fuel Use Act of 1978 is anticipated to result in fuel switching to other conventional fuels.

- Impact of fuel price deregulation is anticipated to be significant after 1985 .

For additional Federal action, priorities can be established by type of technology, as summarized in

- Exhibits 12 and 13:

- The first priority can be placed on MBG multipleuser plants, for four reasons:

- 1 The potential energy impact is as large as the other two configurations combined.

- Tliese die lew, if ariy, Lechnical limitations on gas use.

- Economics are attractive relative to the other equipment configurations-minimal subsidy is needed, if any.

- No plants wi-11 be in operation by 1985, and later development will be slow due to financial risk and institutional complexities.

The most effective Federal initiatives to uvercome key barriers include these specific actions:

- Government-sponsored commercial scale demonstration

- Followed by provision of risk-free capital for initial commercial plants,

- Backed up by environmental policy assurances: 
EXHIBIT. 12

Summary Rationale For Federal Incentives

\begin{tabular}{|c|c|c|c|c|c|c|}
\hline & OPTION & $\begin{array}{c}\text { EXPECTED } \\
\text { MARKET } \\
\text { (W/O INCENTIVES) }\end{array}$ & $\begin{array}{l}\text { POTENTIAL } \\
\text { QUAD } \\
\text { IMPACT }\end{array}$ & $\begin{array}{l}\text { POTENTIALLY } \\
\text { FAVORABLE } \\
\text { ECONOMICS }\end{array}$ & $\begin{array}{l}\text { INSTITUTIONAL } \\
\text { COMPLEXITY }\end{array}$ & TOTAL \\
\hline$\underset{\omega}{N}$ & $\begin{array}{l}\text { LBG } \\
\text { MBG - SINGLE USER } \\
\text { MBG - MULTIPLE USER }\end{array}$ & $\begin{array}{r}\theta \\
0 \\
-0\end{array}$ & $\begin{array}{l}\theta \\
\theta \\
\theta\end{array}$ & $\begin{array}{l}0 \\
0 \\
0\end{array}$ & $\begin{array}{l}0 \\
0 \\
0\end{array}$ & $\begin{array}{l}0 \\
0 \\
0\end{array}$ \\
\hline
\end{tabular}

KEY:

- INDICATES HIGH NEED OR VALUE

- INDICATES POTENTIAL NEED OR MODERATE VALUE

$O$ INDICATES LOW NEED OR VALUE 
EXHIBIT 13

Summary. Effectiveness of Policy Options

\begin{tabular}{|c|c|c|c|c|}
\hline \multirow[b]{2}{*}{$\begin{array}{l}\text { TECHNICAL } \\
\text { OPTION }\end{array}$} & \multicolumn{3}{|c|}{ PROBLEM STATUS } & \multirow{2}{*}{$\begin{array}{c}\text { INITIATIVE } \\
\text { OPTIONS }\end{array}$} \\
\hline & $\begin{array}{l}\text { COMMERCIAL } \\
\text { EXPERIENCE }\end{array}$ & ECONOMICS & $\begin{array}{c}\text { CAPITAL/TECHNICAL } \\
\text { RISK }\end{array}$ & \\
\hline LBG & 'O & $\ominus$ & 0 & $\begin{array}{l}\text { TAX INCENTIVES AND } \\
\text { TECHNICAL DATA }\end{array}$ \\
\hline MBG - SINGLE USẸR & $\ominus$ & - & 0 & $\begin{array}{l}\text { LOW PRIORITY -- NEED } \\
\text { VERY HIGH INCENTIVES }\end{array}$ \\
\hline MBG - MULTIPLE USER & 0 & $\theta$ & 0 & $\begin{array}{l}\text { GOV'T DEMOS FIRST, } \\
\text { PROBABLY RISK CAPITAL } \\
\text { LATER }\end{array}$ \\
\hline
\end{tabular}

KEY:

SÚBSTANTIAL PROBLEM

MODER.GTE PROBLEM

- POSSIBLE PROBLEM, BUT NOT SUB.STANTIAL 
The second priority can be placed on LBG singleuser plants for three reasons:

- The potential energy impact is lower than for MBG multiple-user plants but still significant.

- Economics of LBG can be the most attractive, relative to the other equipment configurations-indicating: potential for substantial response to incentives.

- There is some degree of experience in the U.S., and a number of plants are anticipated to be built in the near term.

The most effective initiative to accelerate immediate LBG market penetration include subsidy incentives, special studies, and policy resolutions:

- Tax incentives to improve LBG economics to the point of attractiveness

- Site-specific engineering studies to resolve uncertainty on the complexities and costs of plant retrofit

- Environmental policy assurances for early adopters.

Finally, the third priority can be placed on MBG single-user plants. The potential for energy impact is estimated to be slightly larger than for LBG. However, MBG. singler-user economics are the least favorable, relative to other equipment configurations. For this reason, the level of incentive required would necessarily be high.

There are several implications for DOE planning. A decision on incentive policy is needed. "Further, a concerted effort to resolve DOE/EPA signals to industry on environmental policy will be well received and effective. In addition, DOE funding of site-specific engineering studies will fill an important dat'a gap on the requirements to integrate gasifiers and existing industrial plants. Finally,. a commercial-scale demonstration program for large-scale plants is attractive to industry and the financial community and is a project which industry expressed a strong desire to help plan.
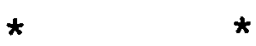

*

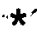


This Executive Summary has touched upon the major findings contained in the main report. Since the summary is printed as a separate volume, its length is somewhat greater than is typical. However, for input into specific government or industry commercialization efforts, it is sincerely hoped that readers will go beyond this summary into the discussions of those areas which interest them most.

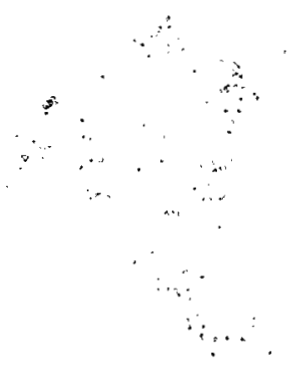


THIS PAGE

WAS INTENTIONALLY

LEFT BLANK 


\section{APPROACH}

The Department of Energy (DOE) developed a program in 1978 for the commercialization of low- and medium-Btu coal gasification (LBG and MBG) systems, consistent with federal energy policy for accelerating coal utilization in the U.S. As an element of planning the commercialization effort, DOE asked Booz, Allen \& Hamilton to conduct an analysis of the industrial market for low- and medium-Btu gasifiers. This chapter provides a brief introduction to the report, including:

$$
\begin{aligned}
& \text { Objectives and scope of the assignment } \\
& \text { - Approach to the s.tudy } \\
& \text { - Exaracteristics of interview participants } \\
& \text { Expected use of the results. }
\end{aligned}
$$

1. THE OBJECTIVE OF THE STUDY WAS TO CHARACTERIZE AND FORECAST THE 1985 MARKET FOR INDUSTRIAL GASIFIERS

The project was designed to meet five fundamental objectives:

- Segment and characterize the industrial market for fuel gas manufactured from coal by industry, application, and region

- Identify industrial investment parameters and decisionmaking processes relevant to the potential purchases of coal gasifiers

- Estimate the industrial market potential in 1985 for low- and medium-Btu fuel gas systems

- Characterize the early adopters and the expected market for 1985

- Estimate the impact of alternative federal actions on the expected market.

The scope of the study focused on the 1985 industrial market. For this reason, analysis concentrated on market potential for existing, commercially-available gasifier equipment. In terms of market scope, the study dealt 
specifically with applications in the manufacturing industries. Utility applications were not included.

2. THE APPROACH TO THE STUDY WAS BASED ON REVIEW OF EXISTING LITERATURE, ORIGINAL ECONOMIC ANALYSIS AND EXTENS IVE INTERVIEWS

The assignment was conducted over a seven-month period in a sequence of five analytical tasks:

- Task 1: Rcview and categorize the market analyses that have been conducted to date for low- and medium-Btu coal gasification systems

- Task 2: Identify and assess the most likely potential markets, now and to 1985:

- By region of the country

- By application

- By industry

- Task 3: Conduct in-depth interviews with representative potential industrial users with regard to their investment decisionmaking process applied to the potential purchase of coal gasifiers

- Task 4: Conduct in-depth interviews with equipment suppliers, architectural/engineering firms and industry organizations with regard to their market perceptions and future plans

- Task 5: Estimate the market potential, identify early adopters and assess federal program options which could accelerate the commercialization of fuel gas-from-coal manufacturing systems.

3. INTERVIEWS WERE CONDUCTED WITH CURRENT USERS, SELECTED POTENTIAL USERS AND THE EQUIPMENT INDUSTRY

With a focus on the near-term (1985) fuel gas-fromcoal market, interviews were conducted with firms in high potential industries, including chemicals, steel, petroleum refining, aluminum, brick, cement, glass, and metal fabrication (Chapter V). From these industries, companies were selected. Which have plants in high potential regions, such as. the Ohio River Valley, Texas, California and Colorado (Chapter VI). 
In total, approximately 75 interviews were conducted for the assignment with executives and key managers in three groups, as summarized in Exhibit $I-1$ and listed in Appendix A.

4. THE REPORT IS INTENDED TO PORTRAY A REALISTIC PERSPECTIVE ON THE INDUSTRIAL MARKET AS A BASIS FOR FURTHER FEDERAL PROGRAM ACTION

The results of the assignment should assist DOE in developing. effective programs which will be of interest to industry participants. Particular attention has been given to:

- Clarifying the size of the technically-feasible market

- Identifying early adopters

- Estimating the number of gasifiers operating or near start-up by 1985

- Identifying the barriers to realizing market potential

- Identifying effective program actions to overcome the key barriers.

To aid DOE in meeting these objectives, analysis of the industrial markets for low- and medium-Btu gasification is provided in the subsequent seven chapters, each of which focuses on a specific key question:

Chapter. II: Under what set of decision conditions is the industrial market operating? This chapter presents an assessment of industrial energy use trends and, current investment perspectivew with regard to interest in gasification as a solution to current problems.

- Chapter III: What are the gasification systems involved? As a basis for looking at marketability in later chapters, a focused assessment of commercially-available gasifiers--including an economic analysis--is presented in Chapter III.

- Chapter IV: What is the current status of gasifier projects? This chapter reviews U.S. and foreign gasification projects as an indicator of current movements in the marketplace. 


\section{EXHIBIT I-I \\ Summary List of Interview Participants}

\begin{tabular}{ll} 
Current User Interviews & \\
\hline General Refractories & General Motors Corporation \\
Glen-Gery Corporation & Holston Defense Corporation \\
Hazleton Brick Company & Howmet Aluminum \\
National Lime \& Stone Company & Land O'Lakes, Inc. \\
Chemical Exchange Company & Pikeville Coal Gasification Project \\
Dow Chemical Company & U.S. Bureau of Mines \\
Gulf \& Western Titanium & University of Minnesota \\
Olin Chemical Corporation &
\end{tabular}

Potential User Interviews

Air Products \& Chemicals

Del Laboratories, Inc.

E. I. DuPont de Nemours

FMC Corporation

Mobay Chemical Corporation

Union Carbide

Armco, Inc.

Inland Steel corporation

Kaiser Aluminum \& Chemical Co.

Kaiser Steel Company

Lukens Steel Company

U.S. Steel Corporation

Ashland Oil

Carter oil. Company

Shell Oil Company

Standard Oil Company of Indiana.

Tennessee Gas Pipeline Company

Union Oil Company

Jeannette Corporation

Midland Glass Co., Inc.

${ }^{P P G}$ Industries, Inc.

Johnson \& Johnson

St.. Regis Paper Company

American Can Company

American Seating Company

Cameron Iron Works

Haussy Metals

Ingalls Iron \& steel

Mansfield Carbon Products

Midrex

Pascoe Steel

Ideal Basic

Martin-Marietta

Acme Brick Company

Brick Institute of America

Athlone Industries

Ball Corporation

Brockway Glass Company

Chattanooga Glass Company

Ferro Corporation

Guardian Industries Corporation

Kerr Glass Manufacturing Company

Owens-Illinois, : Inc.

'Susquehanna Corporation

Mead Paper Company

Equipment Industry Intervlews

American Lurgi Corporation

Applied Technology Corporation

Combustion Engineering

Davy Powergas, Inc.

Gas Generation Associates
Gilbert Associates, Inc.

Koppers Company, Inc. Texaco Development Corporation Wilputte Corporation 
- Chapter V: How large is the potential market: for commercially-available LBG/MBG gasifiers? Based on gas composition, industrial process. requirements and gasifier capacity requirements, this chapter attempts to define the order of magnitude: of the feasible market.

Chapter VI: Where are the most attractive regional markets for coal gasification? High potential states and locations are selected on the basis of actual industrial fuel prices, historical fuel shortages areas and special circumstances due to government regulations.

- Chapter VII: What are the most attractive nearterm applications, and how many plants can be expected to be operating by 1985? Extensive analysis of industry conditions and findings from interviews results in market forecasts for LBG, MBG single-user and MBG multiple-user plants.

- Chapter VIII: What can the federal government do to accelerate. growth of the industrial market for LBG and MBG? Based on problems defined by the marketplace, government.initiatives are assessed for effectiveness. 
THIS PAGE

\section{WAS INTENTIONALLY LEFT BLANK}


II. ANALYSIS OF INDUSTRIAL ENERGY TRENDS AND PREVIOUS GASIFICATION FORECASTS 
II. ANALYSIS OF INDUSTRIAL ENERGY TRENDS AND PREVIOUS GASIFICATION FORECASTS

As an important basis for looking more deeply in later chapters into industrial markets for low- and medium-Btu gasification, this chapter presents an overview of industrial energy trends since 1973 and previous forecasts of LBG/MBG market penetration. Discussion is in three parts:

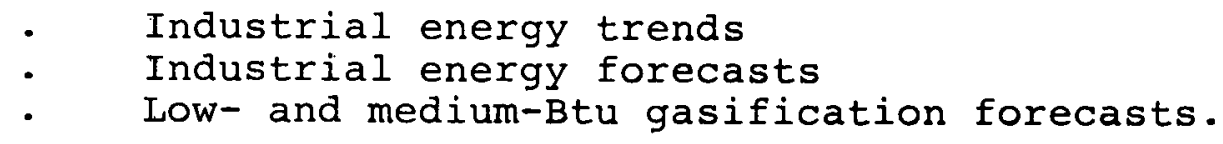

1. SINCE 1973, INDUSTRY HAS IMPROVED ENERGY EFFICIENCY, SWITCHED ITS FUEL MIX TOWARDS OIL AND COAL, MADE MODERATE SUPPLY INVESTMENTS, AND INSTITUTED FORMAL ENERGY MANAGEMENT

Industrial energy consumption has increased substantially over the past several decades for both fuel and nonfuel uses. Since 1973, however, net industrial energy use has dropped slightly, while the nation's total energy use has resumed its growth. Industry now accounts for approximately 37 percent of total U.S. energy consumption, including 4.4 percent of all natural gas consumption and 18 percent of U.S: oil consumption. Recent trends and events which carry implications for industrial investment in coal gasification focus on three factors:

- Energy conservation

- Fuel switching

- Fuel supply investments.

(1) Since 1972, Industry Has Improved Energy Efficiency By More Than 8 Percent--Primarily Through Low-Cost Programs

Industry's cost of energy as a percent of sales is low when compared to other costs. As shown in Exhibit II-1, the average cost to industry in 1975 was equivalent to 2.3 percent of sales.

However, due to rapidly escalating energy costs, industry's attention has been turned toward efficiency improvements to reduce costs. The motivation is seen 
EXHIB IT II-I

Energy Cost Compared to Other

Manufacturing Costs

(All Manufacturers 1975)

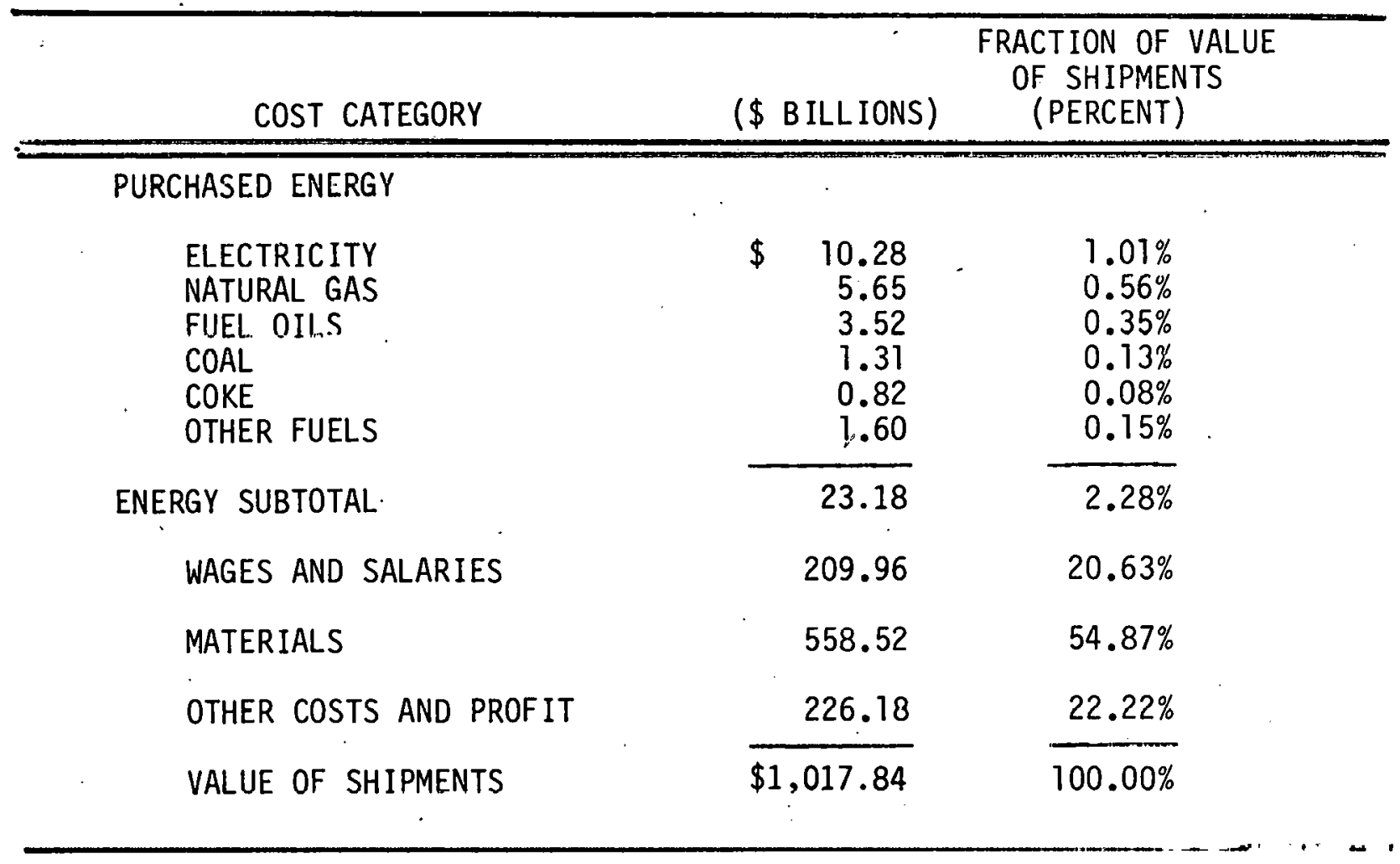

SOURCE: BUREAU OF THE CENSUS, U.S. DEPARTMENT OF COMMERCE, ANNUAL SURVEY OF MANUFACTURERS 1975: FUELS AND

ELECTRIC ENERGY CONSUMED, SEPTEMBER 1977. 
in percentage cost increases. For the period 1971-1975, actual industrial fuel costs increased as follows:

- Residual fuel oil

- Distillate fuel oil

- Coal

- Natural gas

- Purchased electricity
220 percent

205 percent

175 percent

145 percent

75 percent

Increases, however, have not impacted all industries to the same degree. As shown in Exhibit II-2, a few major industries have energy costs at a high percent of sales. The industries. with the highest energy cost percentages are:

$\begin{array}{ll}\text { - } & \text { Cement } \\ \text { - } & \text { Aluminum } \\ \text { - } & \text { Papericals } \\ \text { - } & \text { Glass } \\ \text { - Steel. }\end{array}$

Response to cost, increases has been rapid, with significant results. Reports received from the 50 most energy-intensive companies, in the top 10 energyconsuming industrial sectors, indicates that on a weighted basis, industry improved its energy efficiency. over 8 percent between 1972 and 1976. 'This is a savings of over 2 quadrillion Btu's relative to the anticipated consumption levels without the conservation program. As shown in Exhibit II-3, some industrial sectors have exceeded the 8 percent improvement level, and the machinery sector (SIC 35) has exceeded its 1980 target by almost 30 percent. Indications are that the industries will meet or exceed DOE's Energy Efficiency Improvement Program targets by 1980 .

These improvements have been accomplished through different measures in the various companies but can be categorized as low-cost, high-benefit investments and operational changes:

Waste energy recovery has included the use of waste heat from compressors, dryers, kilns, furnaces, and other equipment; recovery of the heat or cooling effect from ventilation exhaust air; and increased efficiency of heatuse obtained by increasing the size of heat exchangers. 
EXHIBIT II-2

Total Energy Consumption and Cost Importance in Selected Industries.

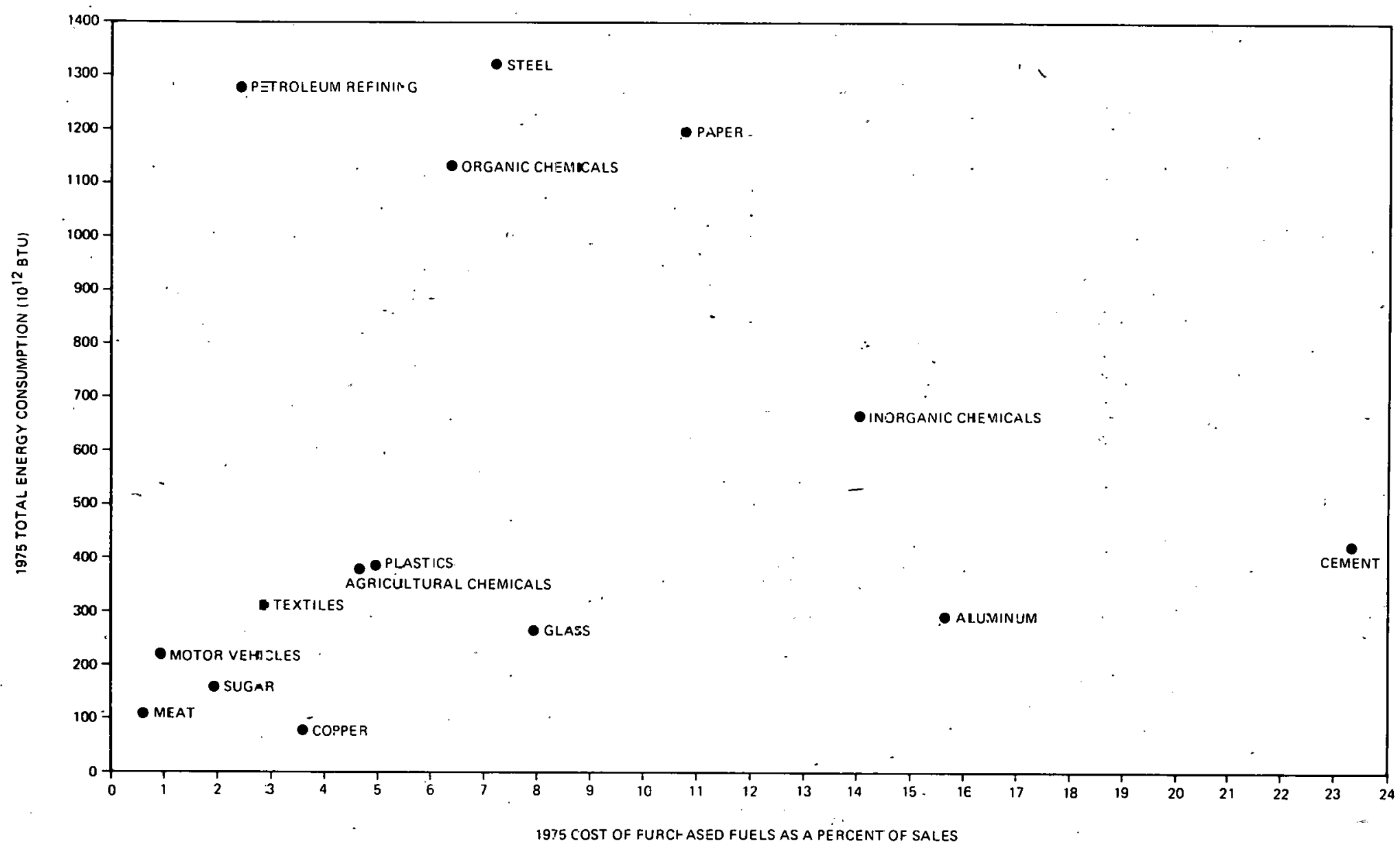

SOURCE: ANNUAL IURVEY OF MANUFACTURERS 1975 DEPARTMENT OF COMMIERCE 
EXHIBIT II -3

Industrial Energy Efficiency Improvements Through 1976

\begin{tabular}{lccc}
\hline \multicolumn{1}{c}{ Industry } & Set & $\begin{array}{c}\text { Net Energy } \\
\text { Efficiency } \\
\text { Improvement } \\
\text { Target } \\
\text { (Percent) }\end{array}$ & $\begin{array}{c}\text { Net } \\
\text { Improvement } \\
\text { Through 1976 } \\
\text { (Percent) }\end{array}$ \\
\hline Food and Kindred Products & 20 & 12 & 11 \\
Textile Mill Products & 22 & 22 & 12 \\
Paper and Allied Products & 26 & 20 & 9 \\
Chemicals and Allied Products & 28 & 14 & 10 \\
Petroleum and Coal Products & 29 & 12 & 10 \\
Stone Glass and Clay Products & 32 & 16 & 8 \\
Primary Metals & 33 & 9 & 4 \\
Fabricated Metals & 34 & 24 & 19 \\
Machinery, except electric & 35 & 15 & 13 \\
Transportation Equipment & 37 & 16 & 8 \\
\hline
\end{tabular}

Source: Annual Report Support Document, Volume II Industrial Energy Efficiency Improvement Program Division of Industrial Conservation Department of Energy DOE/CS-0033/2 
- Improved electrical energy usage has included optimizing plant power factor, optimizing motor sizes and using more efficient lighting.

- Increased boiler efficiency has included minimizing boiler blowdown, repairing or installing steam traps and condensate return lines, better maintenance of burners and injection systems, and improved scheduling of boiler operations.

- Increased use of insulation has included insulating steam lines, condensate lines, and process equipment as well as increased building insulation.

- Low-risk equipment improvements have focused on modifications of processes or process equipment to minimize energy usage and replacement of equipment with new, less energyintensive equipment.

- General energy management has, focused on employee awareness programs, energy audits and controls, the shutdown of units not in use, lowering and raising thermostat levels to reduce-energy use, utilizing waste material as a fuel source, and establishing corporate and plant energy goals with top management review of resilits.

(2) Industry Has Made Substantial Fuel shifts From Natural Gas to Fuel Oil, plus Some progress in Shifting to Coal

The American Gas Association (AGA) reported in 1978 that natural gas curtailments reached an annual level of 3.2 TcF in 1976/1977. Approximately twothirds of the deficit was made up by Residual (No. 6) and Distillate (No. 2 and No. 4) oils, as shown in Exhibit II-4. These data indicate that the natural gas deficit caused oil imports to rise by nearly 1 miliion barrels per day. Nearly half of the 4.2 Quad increase in U.S. oil imports since 1973 were required to offset industrial gas curtailments, according to the AGA. (It should be noted, however, that conversions are now occurring back to gas as gas supplies have improved.)

In addition, there was considerable fuel switching to coal and waste products in some industries, particularly for boilers and kilns. There are two dramatic examples: 
EXHIB.IT II-4

Alternate Fuels Replacing Curtailed Natural Gas

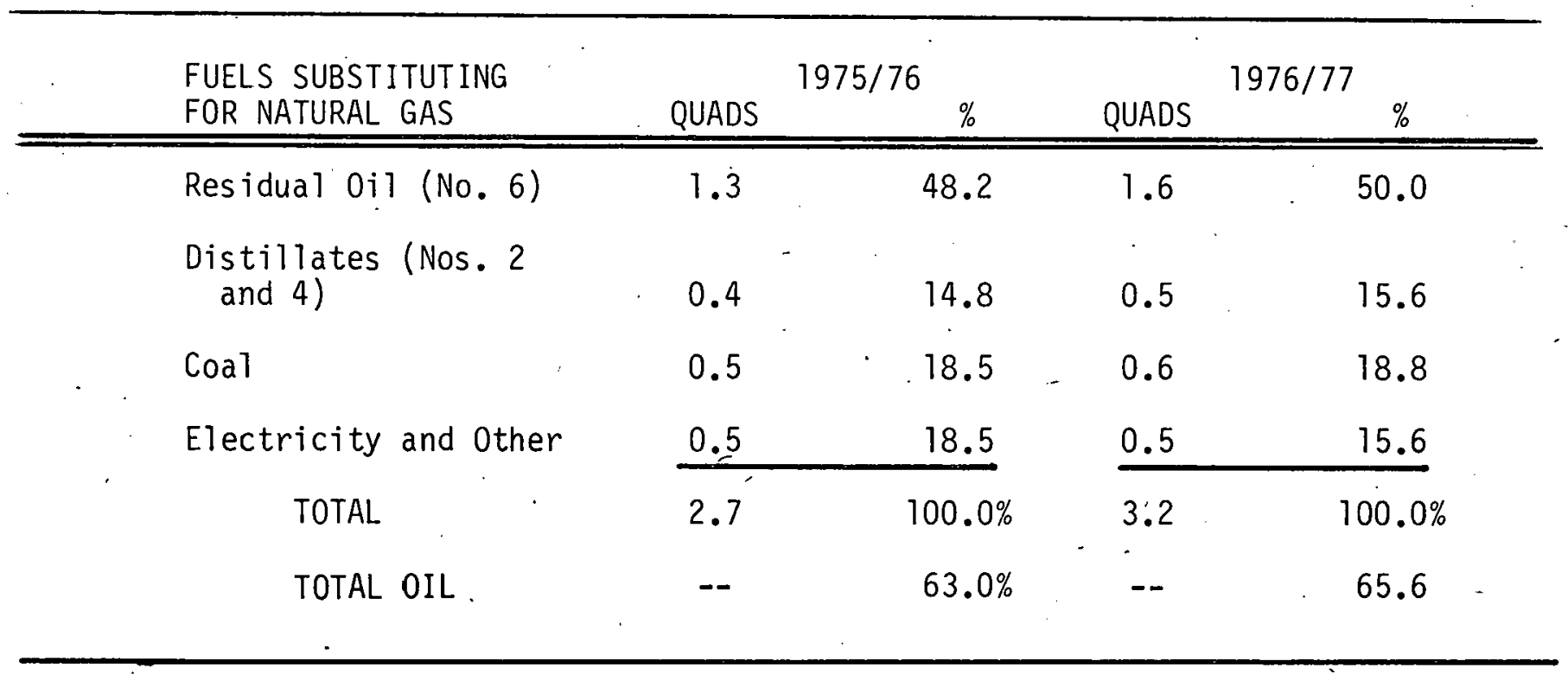

SOURCE: Energy Analysis: The Impact of Gas Curtailments on the Growth of 0 il Imports Since 1973, American Gas Association, September 29, 1978 (based on data from Federal Energy Regulatory Commission). 
- Industry sources indicate that the cement industry may have achieved 85 percent dependence on coal this year.

- The paper industry reports rapid shifts from oil to coal and waste products. Several companies expect to be independent of fossil fuel by 1990 .

(3) Industrial Investment in Backup Fuel Supplies and Capabilities Has Increased and a Number of Comparies Have Invested in Oil, Natural Gas, and Coal Resources

The extent of the increased industrial investment in filel supply by non-energy companies is complex, not well documented, dud somewhat proprictary to oach rnmpany. However, based on several years of intensive contact with industry and a large. number of industrial energy assignments, Booz, Allen has concluded:

- Nearly all U.S. plants in areas threatened by supply shortages have developed dual-burner capability (oil and natural gas and\%or propane)

Fuel oil and/or propane storage facilities have been installed for 30- to 60-days of operating

- Coal storage facilities have been expanded in some businesses.

Direct investment in energy supplies has become more prevalent in the past few years. The steel industry has for years owned captive coal and its recent investments have also included small oil wellfield companies and self-help natural gas. Chemical and petroleum companies have increased their purchases of coal reserves.

After several years of actlvity to yain increaeed burgy security, industry has made progress. Energy efficiency is improved. Fuel switching has been carried out based on economic and supply risk (judgmental) factors. Steps have been taken to reduce the risk of supply shortfalls. Finally, industry has gained substantially in capability to manage its energy proglems.

With this background, the next section addresses the near-term outlook on industrial energy trends. 
2. THE QUESTION OF OIL AND GAS AVAILABILITY IS THE KEY TO THE 1985 INDUSTRIAL FUEL MIX

Booz, Allen \& Hamilton recently conducted an extensive analysis to forecast overall U.S. energy trends. This section presents highlights of that forecast together with the findings from interviews conducted for this LBG/MBG study. Major conclusions are presented in four sections:

- Industrial energy growth

- Industrial fuel mix

- Fuel price outlook

- Anticipated industry activity.

(1) Industrial Energy Consumption Is Forecast to Grow More Rapidly Than Any Other Sector to 1995

Booz, Allen's current forecast, according to base case assumptions, of U.S. energy consumption by sector is shown in Exhibit II-5:

- Industrial energy consumption is forecast to increase at an average annual rate of $3 .^{\prime} 6$ percent until 1985 and 3.7 percent between 1985 and 1995.

- Other end-use sectors are forecast to grow substantially slower--transportation energy consumption at 0.6 percent until 1985 and the residential/commercial sector at 1.2 percent until 1985, on average, annually.

There are a vast number of component estimates and forecasts underlying the overall forecast conducted in Spring 1979.

(2) Present Industrial Trends Toward Increased coal Use and Electricity Demand Will Continue; Recent Trends Away From the Use of Natural Gas Will

- Reverse in the Short-Term in Response to Supply Availability and cost compared to Fuel oil

Booz, Allen's current forecast of the industrial fuel mix is shown in Exhibit II-6. The key conclusions are as follows:

Industry will respond to the near-term availability of natural gas, encouragement by gas utilities to continue carrying a major load 
THE ENERGY OUTLOOK . . .

\section{THE INDUSTRIAL SECTOR'S ENERGY USE WILL GROW THE FASTEST}

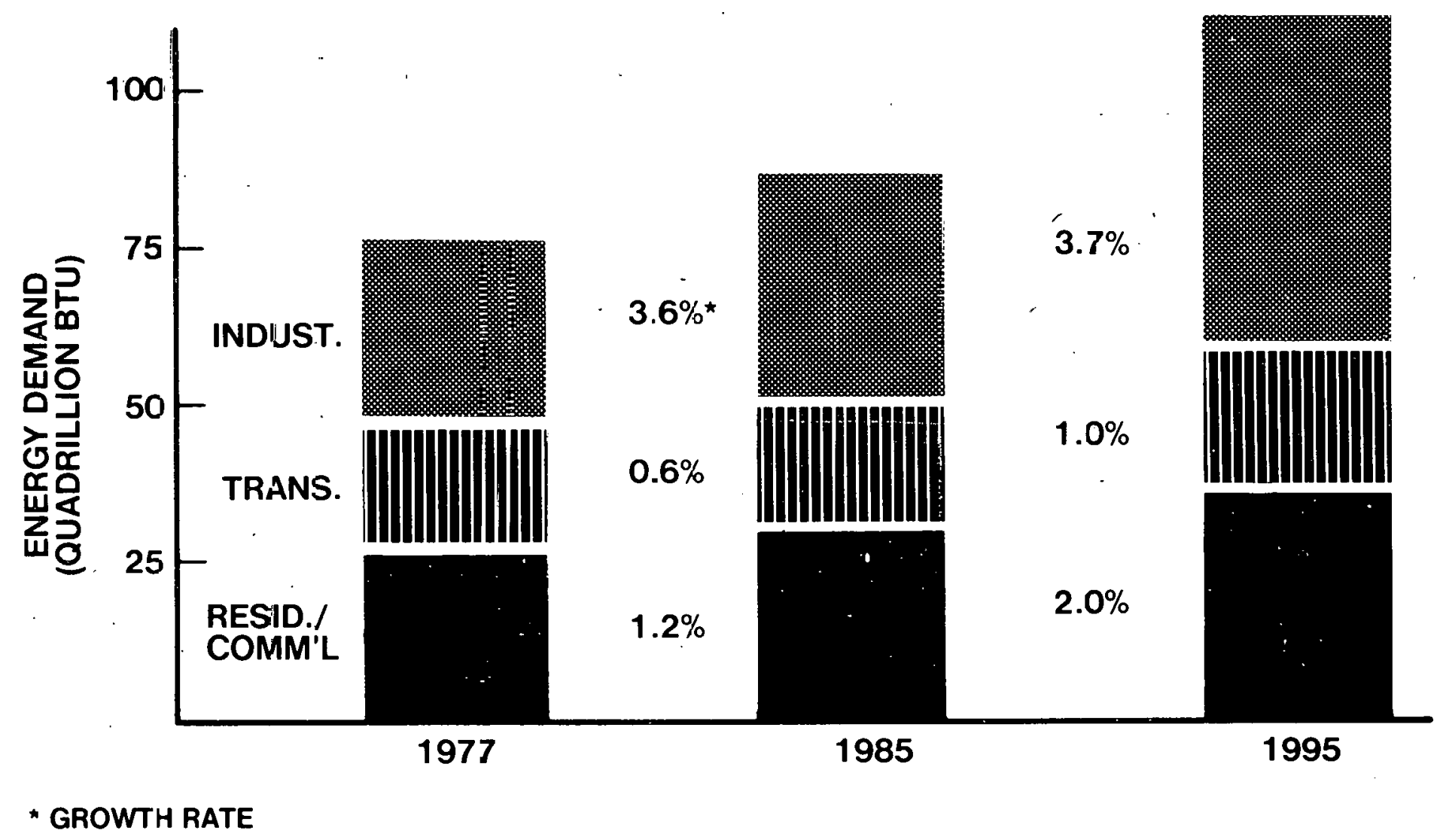


THE ENERGY OUTLOOK . . .

\section{COAL AND ELECTRICITY USE IN IMDUSTRY WILL EXPAND}

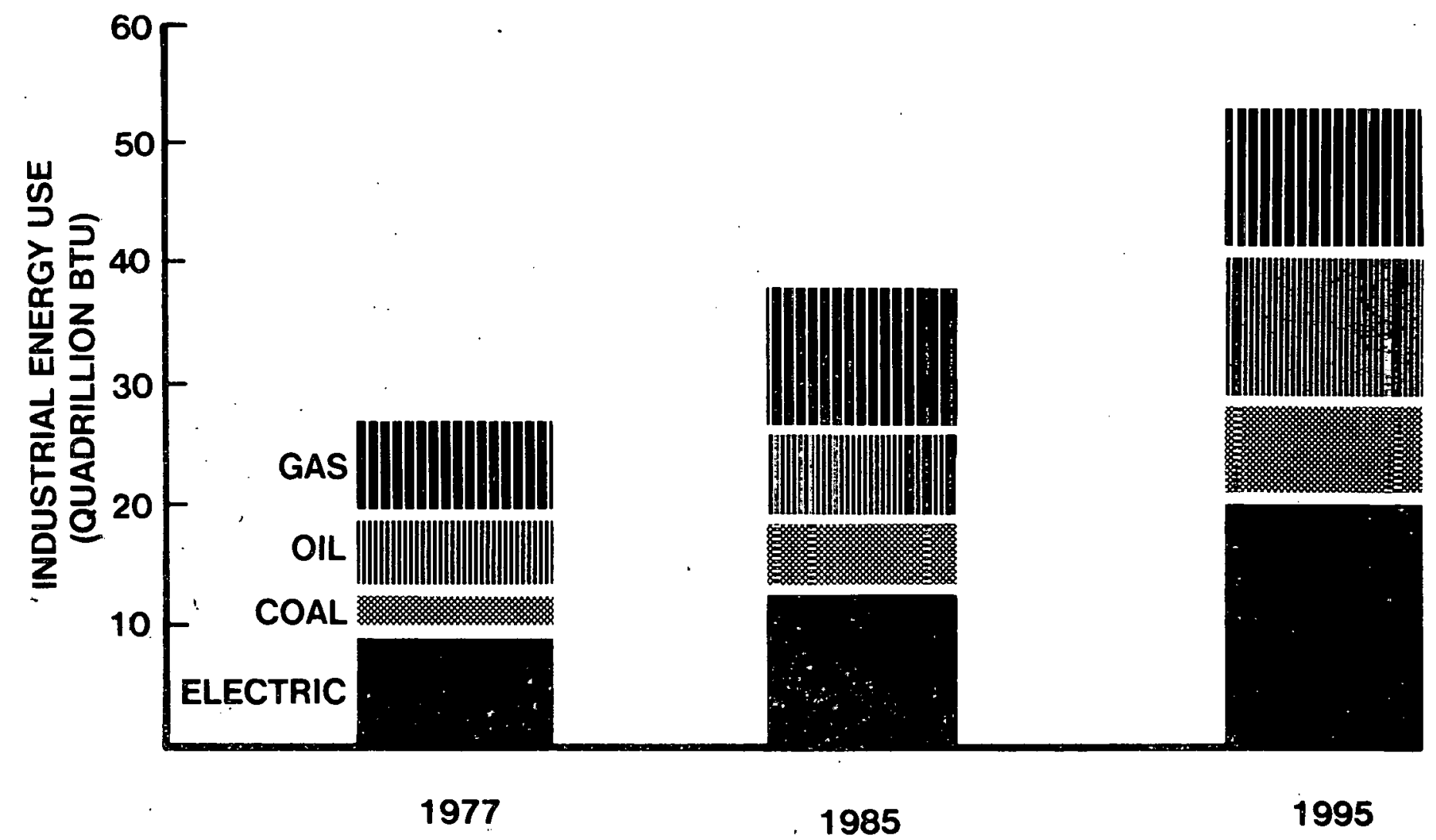


and encouragement from government to switch back to natural gas to alleviate pressures on imported oil.

- Industrial oil consumption will grow more slowly than other fuels.

- Coal consumption by industry could approximately double by 1985 from 1977 levels, particularly if uncertainties on environmental regulation are reduced.

- Electricity consumption will increase steadily.

These overall trends will have substantial regional variation in response to availability, price, and perceived short-tcrm security.

(3) Industrial Fuel Prices Will Increase At a Rate Which Is Exceedingly Uncertain At This Time

The preceding Booz, Allen analysis and forecast contained specific Base case price and price increase assumptions as a vehicle for forecasting. The range of forecasts provides a tool for identifying the implications of risks (i.e., knowing what the possible component outcomes might be, but not knowing which one will actually happen).

However, analysis cannot characterize true uncertainty, which is not even knowing what the various component outcomes could be (e.g., U.S. and foreign government actions).

At the time of this report, industry views future energy prices as highly uncertain, due to the unpredictability of government actions. The focal point is world oil prices. Industrial managers who hold views on future world oil prices fall into two groups:

- Those who assume that oil price increases wi.1. be held to a level moderately over inflation (e.g., 2 percent real increase. annually) due to the need for world economic stability and the potential for larger non-OPEC production

- Those who assume that recent events will continue with resulting massive price increases. 
In addition to world oil price movements, the question of U.S. oil price controls is unanswered, although current decontrol pressures are developing.

With regard to coal prices, most studies concerning coal conversion tend to assume moderate (inflation level) increases. However, supply/demand conditions are expected to continue affecting coal price movements erratically (e.g., current spot prices are lower than contract prices). EPA regulations will continue to impact demand, with resulting uncertain implications on supply growth, and on the linkage between oil. and, coal prices.

Industrial natural gas price movements are keyed to wellhead prices and incremental industrial pricing provisions of the Natural Gas Policy ACt of 1978 . Rapid increases are anticipated by industry. However, the rate of increase will be affected by two uncertainties:

- Movements in the "ceiling" price of fuel oils

- Actions by gas utilities to preserve industrial customer demand.

Industrial electric rates will increase. However, the rate and extent of increase is tied to regulatory provisions still in development (e.g., incremental pricing, time-of-day rates, etc.) plus downstream uncertainties for electric utilities, such as nuclear plant expansion, EPA regulations on coal-fired plants, and the method by which DOE fuel use regulations are implemented.

Industrial reaction to fuel price increases can be expected to occur on a relative basis. The major uncertainty is how prices of each fuel will increase relative to each other, over and above the underlying uncertainties surrounding individual fuels. Implications of these uncertainties are presented in the next section.

(4) Companies Interviewed for the study Anticipate Few Energy-Related Decisions in the Next Few Years; Most Companies Are Taking a "Wait and See" Attitude

Over 50 potential industrial users in eight key industries were interviewed for the study. There are 
two significant differences between the tone of the interviews compared to similar discussions held in mid-1977 for a comparable study:*

- Industry exhibits a lesser degree of "panic" in the energy conditions than 2 years ago

- Most companies have taken action to protect against supply insecurities and are substantially more expert and informed on their options for the future.

For example, Exhibit II-7 presents summary comments from 25 representative discussions, illustrating company situations and anticipated actions. From the individual comments, it is clear that:

Most firms have invested in backup fuels, and/or base supplies for a fraction of their needs.

- The near-term outlook on supply security is generally positive, with some isolated exceptions. Industry does not anticipate. energy-caused shutdowns in the early $1980^{\prime} \mathrm{s}$.

- I'nere áre few plans to 1nvest capital in energy supply.

- Industry is well informed on its options and continues to study future alternatives.

- The major decision factor is economics--as represented in fuel prices.

- Industry is waiting for government energy and environmental policies to settle before making long-term investments.

Resulting from six years' experience since 1973 in energy problems, industry is increasingly rational in investment decisionmaking. The period of rapid, reaction decisions appears to be ending.

* Development of the Strategic Plan for Industrial Energy Conservation, prepared for DOE by Booz, Allen \& Hamilton, June 1, 1978. 


\begin{tabular}{|l|l|}
\hline CHEMICALS & $\begin{array}{l}\text { Anticipates no energy supply investments; supply security is secondary to } \\
\text { price; keeping track of oil supply situation }\end{array}$ \\
- Gas bubble won't last--but do not view gas supplies as problematic; boilers \\
equipped with dual fuel capability; no energy investments expected; decisions \\
made on economics \\
- Recent curtailments in $N$. Carolina, Utah, and Kansas; expect gas supplies to \\
improve; investments made in coal and gas; no additional investments planned; \\
now planning for late 1980's; inability to predict federal actions is major \\
deterrent to decisions
\end{tabular}

\begin{tabular}{|c|c|}
\hline REFINING & $\begin{array}{l}\text { - Foresees no significant fuel problems; highly flexible; frequent fuel changes; } \\
\text { economics drive tuel choices; } \text { will respond to impacts of fuel price regulation } \\
\text { and environmental restrictions } \\
\text { - Natural Gas Policy Act and Fuel Use Act will free up gas supplies; use a wide } \\
\text { variety of fuels; minimize waste; maximize short-term economics } \\
\text { - Putting funds into EOR, tar sands, shale oil, etc; government regulation is key } \\
\text { determinant to process fuel use; uncertainty on link between oil and coal } \\
\text { prices } \\
\text { - Use mixture of natural gas and off-gases; curtailments are old problem--not } \\
\text { recent; no concerns for security; economics is the overriding factor; sensitive } \\
\text { to federal regulations; question conflict between FUA of } 1978 \text { and EPA } \\
\end{array}$ \\
\hline $\begin{array}{l}\text { METAL } \\
\text { FABRICATION }\end{array}$ & $\begin{array}{l}\text { - Has made no significant supply investments; confident in current suppliers } \\
\text { (70 plants nationwide); coal contracts; some gas curtailments but used propane } \\
\text { backup; see gas bubble for next } 3 \text { years; have investigated oil/gas properties; } \\
\text { no investments expected; federal action key to company decisions } \\
\text { - Converted in } 1971 \text { from coal to gas; now converting back to coal; economic } \\
\text { drivers; gas supplies are secure } \\
\text { - Need clean fuels; drilling own captive wells; highly concerned about natural } \\
\text { gas availability } \\
\text { - Company is continuing action to ensure energy security; own some supplies; } \\
\text { self-help gas; investigating all options; take no risks on supply }\end{array}$ \\
\hline CEMENT & $\begin{array}{l}\text { - Nearly complete in coal conversion; started in } 1974 \text {; will be complete coal by } \\
1981 ; \text { can use any type of coal; concern is for electricity supply; no other } \\
\text { investments expected } \\
\text { - Switched } 7 \text { of } 8 \text { plants to coal in early } 1970 \text { 's; no other supply investments } \\
\text { under cunsideration }\end{array}$ \\
\hline STEEL & $\begin{array}{l}\text { - Integrated plants highly flexible; concerned about gas supply to non-integrated } \\
\text { plants; conipany owns coal, oil, and gas supplies; confident that oil will be } \\
\text { available for swing fuel; but looking at all options; expect dramatic situation } \\
\text { when gas prices near oil prices } \\
\text { - Currently substituting natural gas and coke ovens gas for oil; economic } \\
\text { decisions; company committed to idea that oil/gas will be available beyond } \\
2000 ; \text { no investments planned } \\
\text { - Owned coal since } 1940 \text { 's; concerned about gas supply but not panicked; fuel oil } \\
\text { backup; no supply investments in } 1979-1985 \text { time frame; economics are key; } \\
\text { shortage affects everyone; NEA impacts are unclear; company watching situation } \\
\text { - virtualiy } 100 \% \text { electric; no energy supply problems anticipated; no investments } \\
\text { made or expected }\end{array}$ \\
\hline
\end{tabular}


4. PREVIOUS MARKET STUDIES FOR LOW- AND MEDIUM-BTU GASIFICATION INDICATE A HIGH POTENTIAL FOR 1985

Previous studies of the industrial market for low- and medium-Btu gasification were reviewed during the initial task of the assignment. Each study took a unique approach to analysis, considered different market-affecting factors, based economic conclusions on unique assumptions and, not surprisingly, reached unique conclusions. Highlights are presented in two sections:

- Potential markets

- Market forecasts.

(1) Nearly All Major Industries Have Been Identified As Attractive Applications for LBG and MBG

Nine studies reviewed for the assignment reached conclusions on attractive market opportunities for LBG and MBG. Results are summarized in Exhibit II-8.

At least 11 industries have been identified as "high potential" applications for LBG and MBG :

- Basic iron and steel

- I Ferrous foundries.

- Non-ferrous foundries

- Petroleum refining

- Chemicals

- Cement

- Glass

- Lime

- Brick

- Pulp and paper

- Auto, truck, and related equipment.

There has, however, been no unanimous selection of a "best" industry for LBG/MBG

All studies tended to characterize the market potential per industry as conditionally attractive. That is, opportunity depends upon site-specific conditions (Chapters $V$ and VII of this report address industry and application attractiveness). 
EXHIBIT II-8

Selection of High Potential Industries

$\mathrm{F}=\mathrm{cm}$ Recent Studies

\begin{tabular}{|c|c|c|c|c|c|c|c|c|c|c|}
\hline & \multirow[b]{2}{*}{ IND USTRY } & \multicolumn{9}{|c|}{ STUDIES } \\
\hline . & & $\begin{array}{c}\text { BATTELLE } \\
1974\end{array}$ & $\begin{array}{l}\text { COLUMBIA } \\
\text { GAS } \\
1976\end{array}$ & $\begin{array}{r}\text { EEA } \\
1977\end{array}$ & $\begin{array}{l}\text { NAS } \\
1977\end{array}$ & $\begin{array}{l}\text { SRI } \\
1978\end{array}$ & $\begin{array}{c}\text { GILBERT } \\
1978\end{array}$ & $\begin{array}{c}\text { UNION } \\
\text { CARBIDE } \\
\text { 1978 }\end{array}$ & $\begin{array}{c}\text { DRAVO } \\
1978\end{array}$ & $\begin{array}{c}\text { SCl } \\
1978\end{array}$ \\
\hline METALS: & $\begin{array}{l}\text { BASIC IROW \& STEEL } \\
\text { FERROUS FOUNDRIES } \\
\text { NONFERRDUS METALS }\end{array}$ & 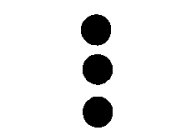 & & $\theta$ & & & & & & 0 \\
\hline $\begin{array}{l}\text { PETROLEUM: } \\
\text { CHEMICALS: }\end{array}$ & $\begin{array}{l}\text { REFINING } \\
\text { GENERAL } \\
\text { AMMONIA } \\
\text { OTHER MISC. }\end{array}$ & $\theta$ & & 0 & . & 0 & 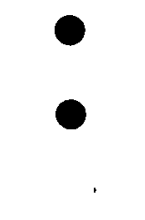 & & $\stackrel{\theta}{\ominus}$ & $\stackrel{0}{0}$ \\
\hline MATERIALS: & $\begin{array}{l}\text { CEMENT } \\
\text { GLASS CONTAINERS } \\
\text { LIME } \\
\text { BRICK }\end{array}$ & & 0 & 0 & , & 2 & $\begin{array}{l}\theta \\
\theta \\
0\end{array}$ & & $\stackrel{\theta}{9}$ & $\theta$ \\
\hline $\begin{array}{l}\text { PAPER: } \\
\text { TRANSPORTATION. }\end{array}$ & $\begin{array}{l}\text { PAPER MILLS } \\
\text { PAPERBOA.RD MILLS } \\
\text { AUTO TRUCK } \\
\text { \& HEAVY EQUIPMENT }\end{array}$ & & & & & & ? & & $\theta$ & $\stackrel{\theta}{\theta}$ \\
\hline
\end{tabular}

KEY: hIGHLY ATTRACTIVE

POTENTIALLY ATtRACTIVE 
(2) Market Forećasts for 1985 Range From 0.1 Quad to Over 1.0 Quad

Recent 'conclusions on LBG/MBG market potential vary widely, depending upon markets included, assumptions made, and whether estimates were made for "potential" market or "expected" market for LBG alone, MBG alone, or all coal gasification, as shown in Exhibit II-9. For 1985, forecasts were as follows:

The 1977 ERDA Market Oriented Program Planning study (MOPPS) forecast 1.2 Quads from LBG and MBG in 1985.

- SRI International (1978) forecast 0.65 Quads MBG in 1985 .

- DOE Commercialization Task Force (1978) forecast 0.012 Quads from LBG and 0.04 Quads from MBG in 1985 .

- Energy \& Environmental Analysis, Inc. (1977) forecast 0.029 Quads from LBG and 0.018 Quads from MBG by 1985 .

Each study was conducted in a different period and reflects reasonable assumptions for the respective time. The recent environment has, however, been dynamic. To illustrate, Exxon Company, U.S.A. published the following comments with regard to gas from coal:

Energy Outlook 1978-1990 (May 1978): Gas from coal is projected to be commercially available beginning in the early 1980's. Total annual synthetic gas production is expected to reach 1 : Tcf by 1990

- Energy Outlook 1979-1990 (December 1978): Gas from coal is projected to be commercially available beginning in the mid-1980's. l'otal annual synthetic gas production is expected to approach 0.7 Tcf by 1990 .

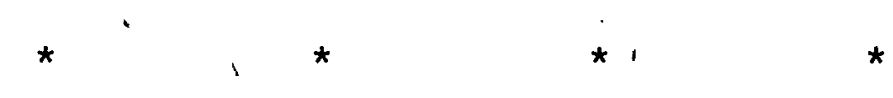


EXHIBIT II-9

Market Penetration Forecasts

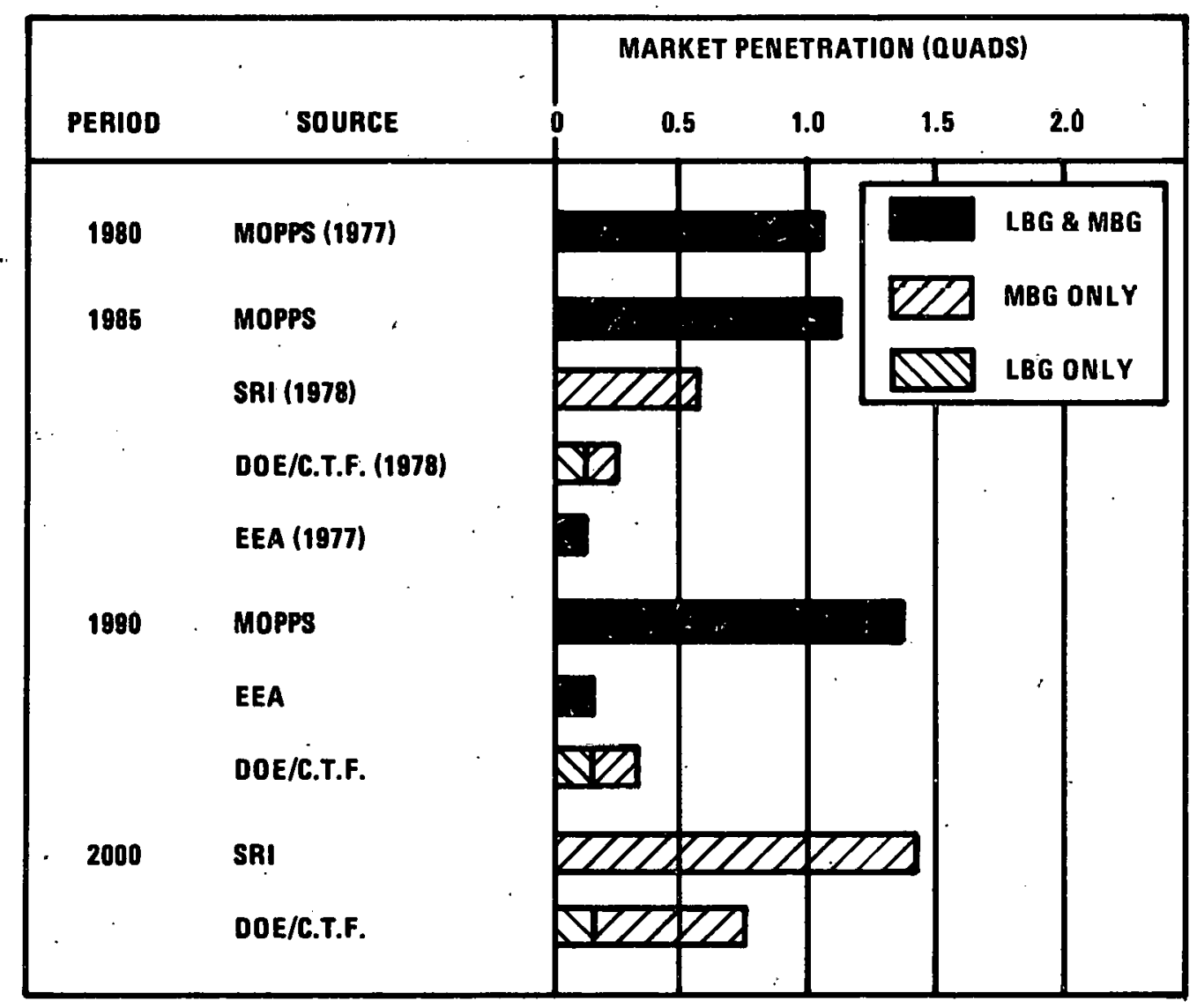


This chapter has presented the principal background for the study, in terms of industrial energy trends, industrial energy forecasts, and previous LBG/MBG market studies. The chapter has described, that is, the context within. which industry will make, investment decisions on LBG and MBG coal gasification. The bottom line is vast uncertainty, and moderate divergence of views on LBG/MBG market opportunity.

Due to the highly fluid and uncertain conditions underlying the marketplace, our approach 'to' the study was to:

- Establish the facts to the extent possible on the technology, and on current users and projects

- Establish the facts on the regional nature of coal and fuel oil prices

- Conduct extensive interviews with potential users to identify intended actions

- Conduct near-term 1985 market forecasts on the basis of findings from the marketplace.

The following chapter focuses on the technology and current economics of commercially-available gasifiers, as a basis for assessing marketability. 
THIS PAGE

\section{WAS INTENTIONALLY LEFT BLANK}


III. ASSESSMENT OF COAL GASIFICATION TECHNOLOGY AND ECONOMICS 


\section{ASSESSMENT OF COAL GASIFICATION TECHNOLOGY \\ AND ECONOMICS}

This chapter presents an analysis of the existing coal gasifier technologies and processes, including their characteristics, limitations, and the resulting technical and economic trade-offs facing the industrial user. Analysis and discussion is presented in three parts:"

- Identification of commercially available equipment

- Analysis of the key factors in selecting gasifier equipment

- Analysis of LBG and MBG economics.

1. THERE: ARE AT LEAST FORTY EXISTING, EMERGING AND

ADVANCED GASIFIERS IN EIGHT DIFFERENT TECHNOLOGY

CLASSIFICATIONS. FIFTEEN ARE EXPECTED TO BE

COMMERCIALLY AVAILABLE FOR 1985

There are over 40 gasifiers described in the literature, ranging from the old fixed bed, dry ash gasifier developed in the 1930's, to new gasifiers which will become commercial in the 1990's. Exhibit III-l identifies the best known technologies and processes.

Given the period under consideration, 1979-1985, it is reasonable to assume that the adoption of low- or medium-Btu gasification during this time frame will take place with processes chosen from among the fifteen currently judged commercial, as listed in Exhibit III-2.

For the purposes of the study, a commercial process is defined as one which, when operating within well-defined parameters, presents acceptable technical and operating security. To meet this criterion, a process should have operated at a commercial scale, and in steady state conditions, for about 2 years. Thirteen gasifiers meet the criterion, as noted by an asterisk $\left(^{*}\right)$ in Exhibit III-2.

Two of the gasifiers considered in this study, the Texaco. and the Combustion Engineering (CE), clearly do not meet the criterion. However, their advanced stages in what 
EXHIBIT III-1

Eristing, Emerging and Advanced Gasifiers

\begin{tabular}{|c|c|c|c|c|c|}
\hline & $\begin{array}{l}\text { Fixed 3ed } \\
\text { (Moving 3ed.) }\end{array}$ & Fluidized Bed & Entrained Flow & Molten Bath & $\begin{array}{l}\text { Underground } \\
\text { - Gasification }\end{array}$ \\
\hline $\begin{array}{l}\text { Dry } \\
\text { Ash }\end{array}$ & $\begin{array}{l}\text { Lurgi } \\
\text { Koppers-lierpely } \\
\text { Wellman-Galusha } \\
\text { Wellman- } \\
\quad \text { Incandescent } \\
\text { Davy-Powergas } \\
\text { Cegas } \\
\text { Merc } \\
\text { Kellog } \\
\text { WD/GI } \\
\text { Riley-Morgan } \\
\text { Willputte } \\
\text { Stoic } \\
\text { Pullman-Swindeli/IFE }\end{array}$ & $\begin{array}{l}\text { Winkler } \\
\text { Synthane } \\
\mathrm{CO}_{2}-\text { Acceptor } \\
\text { Exxion } \\
\text { HRI } \\
\text { Cogas } \\
\text { BCR } \\
\text { IGT }\end{array}$ & $\begin{array}{l}\text { Bigas } \\
\text { Combustion Eng. } \\
\text { Occidental }\end{array}$ & - & \\
\hline Slagging & $\begin{array}{l}\text { BG/Lurgi } \\
\text { ERDA/GFEFC } \\
\text { Thyssen-Ea loczy. } \\
\text { Leuna-Worth }\end{array}$ & . & $\begin{array}{l}\text { Koppers-Totzek } \\
\text { Texaco } \\
\text { B\&W } \\
\text { Ruhrgas } \\
\text { Otto Rummel }\end{array}$ & - & 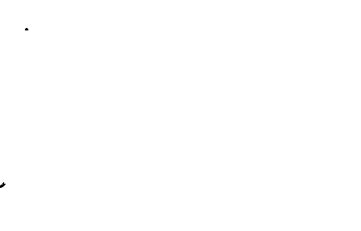 \\
\hline Agglomerating & 1 & $\begin{array}{l}\text { Unian Carbide/ } \\
\text { Battelle } \\
\text { U-Gás } \\
\text { Westinghouse } \\
\text { ICI }\end{array}$ & & & . \\
\hline other & . & & . & $\begin{array}{l}\text { North American } \\
\text { Rockwell } \\
\text { Kellog } \\
\text { Rummel }\end{array}$ & $\begin{array}{l}\text { Laramie } \\
\text { Lawrence/ } \\
\text { Livermore } \\
\text { Morgantown } \\
\text { Soviet processes }\end{array}$ \\
\hline
\end{tabular}


EXHIBIT III-2

Commercially Available Gasifiers

\begin{tabular}{|c|c|c|c|c|}
\hline Gasification Type & Gas Pressure & Gasifier & LBG & MBG \\
\hline \multirow{9}{*}{$\begin{array}{l}\text { Fixed Bed } \\
\text { (Moving Bed) }\end{array}$} & - Pressurized & Lurgi & $x$. & $x$ \\
\hline & - Atmospheric & *Wellman-Galusha & $x$ & $x$ \\
\hline & - Single Stage $\star \star$ & *Wilputte & $x$ & $x$ \\
\hline & & *Riley-Mórgan & $x$ & $x$ \\
\hline & - Two Stage $\star \star \star *$ & $\begin{array}{l}\text { *Davy-Powergas } \\
\text { *Wellman-Incandescent }\end{array}$ & $x$ & $x$ \\
\hline & & *Stoic & $x$ & $x$ \\
\hline & & *Pullman-Swindell/IFE & $x$ & $x$ \\
\hline & & *Woodal I-Duckham/GI & $x$ & $x$ \\
\hline & & $\begin{array}{l}\text { *Koppers-Kerpely } \\
\text { *Davy-Powerqas }\end{array}$ & $x$ & $x$ \\
\hline Fluidized Bed & - Atmospheric & *Winkler & $x$ & $x$ \\
\hline \multirow[t]{2}{*}{ Entrained Flow } & - Pressurized & Texaco & $x$ & $x$ \\
\hline & - Atmospheric & $\begin{array}{l}\text { *Koppers-Totzek } \\
\text { Combustion-Engineering }\end{array}$ & $x$ & $x$ \\
\hline
\end{tabular}

*Indicates processes which have operated commercially.

**Atmospheric single stage gasifiers are based on the same process, with minor variations.

$\star \star \star$ Two stage gasifiers are based on the same process, with minor variations. 
have been successful development projects so far, coupled with the high probability that they will be commercial by 1985, at least in some of their operating modes, justifies their inclusion in the group of commercial processes.

2. SELECTION OF A GASIFIER FOR ANY PARTICULAR APPLICATION IS A HIGHLY COMPLEX ANALYSIS OF APPLICATION REQUIREMENTS AND EQUIPMENT PERFORMANCE

Determining the applicability of coal gasification to an industrial process is complex. Necessary analysis includes detailed consideration of at least six key factors:

- Industrial process and energy use requirements

- Gasifier process characteristics

- Coal feed requirements and coal supply

- Type and quality of gas produced

- Retrofitting requirements

- Environmental implications.

The first factor, industrial process and energy use requirements, is discussed in.later chapters. In this section, the remaining five factors listed above are assessed.

(1) Each Type of Gasification Process Offers Distinct Advantages and Disadvantages to Potential Users

A brief description and characterization must be made of the three technologies on which the available commercial processes are based. More detailed treatment of individual processes is to be found in the available literature. A good and widely used sourcebook on gasifier characteristics is the "Handbook of Gasifiers and Gas Treatment Systems" produced by the Dravo Corporation, Pittsburgh.

Exhibit III-3 briefly describes and characterizes the commercially available gasification routes. As the subsequent analysis will show, there is no. simple or general solution to using coal gasification. Several operating variables impose more or less serious constraints on the choices available to potential industrial users. 


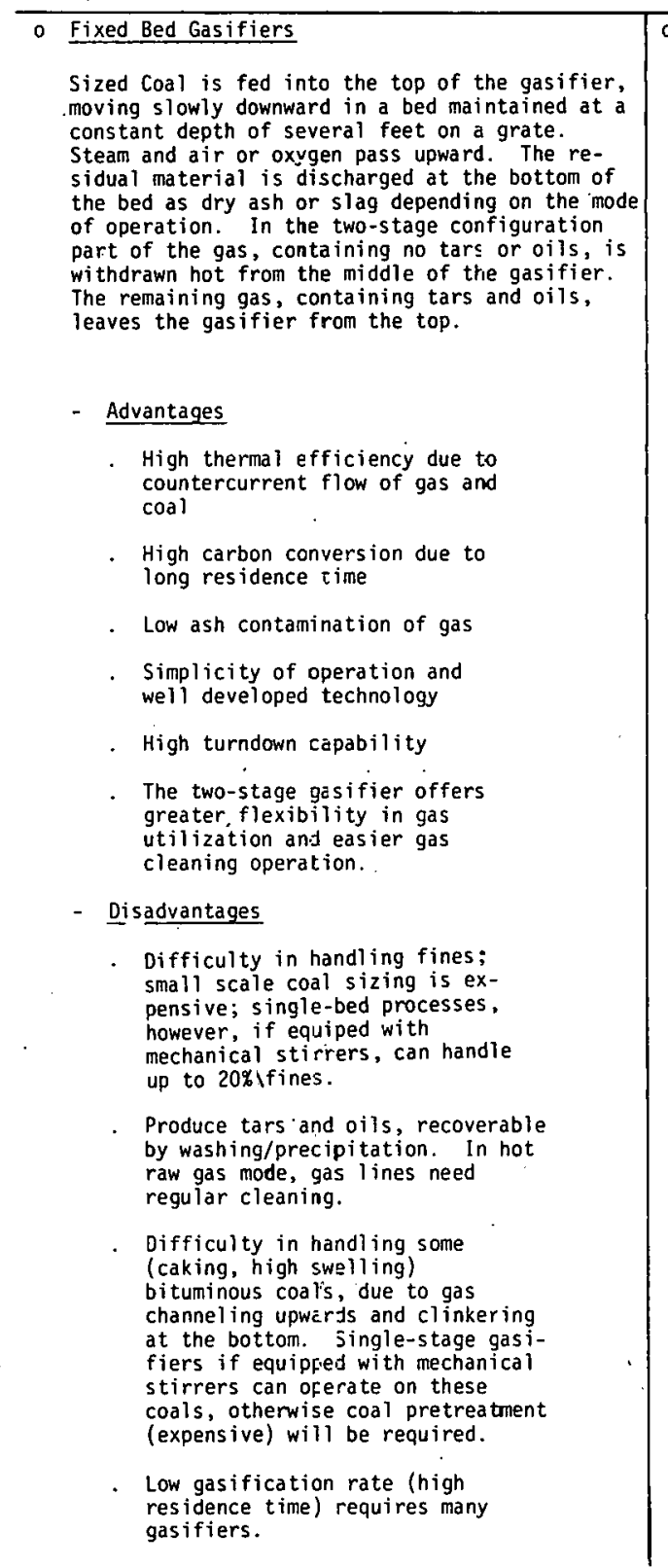

\section{- Fluidized Bed Gasifiers}

Similar to fixed bed except that the velocity of the dir-or oxygen-steam high enough and the from the bottom is small enough for the coal to be suspended in the upward flowing gas stream. The to stay in the vessel.

\section{Advantages}

Good gas-sol id mixing promotes excellent heat and mass transfer characteristics, hence uniform minimizing hot spots and clinker formation.

Higher gasification rates than fixed bed

Good turndown capability, but lower

Coal fines from mining and crushing may be used as a portion of the feed.

\section{- Oisadvantages}

Poor carbon utilization lowers gas hydrocarbon gases

- Caking coals require pretreatnient due to possible aglomeration in the bed leading to loss of proper

High ash carry over

- Limited range of operating conditions because of fluidization characteristics of particles and danger of entrainment.

\section{- Entrained Flow Gasifiers}

Similar concept to fluidized bed except that pulverized coal is injected into high velocity concurrently flowing stream of air or oxygen and steam. The gas velocity is so high that
the coal is carried along with the gas stream. the coal is carried along with the gas stream. from the product gas. As the stream is concurrent, reaction rates decrease with displacement through the gasifier, hence high temperatures are required to keep reactor size reasonable.

\section{- Advantages}

No pretreatment of caking coals required due to very low rate

No tar or phenol production due to high temperature

- High reaction rate hence higher coal throughput than with either fired or fluidized bed gasifiers

\section{- Disadvantages.}

High temperature requirements may only be achieved by oxygen System turndown capability lowest

Air blown and two stage gasification still under development

Large carry-over of fine particles, short refractory life and unreliable coll feeding

High temperatures require heat 
(2) The Type of Coal Available to Each Potential Application W1ll Determine--to a Substantial Degree--the Type of Gasifier selected

Exhibit III-4 shows the geographical distribution of U.S. coals by rank. A particular concern to small capacity users is the fact--not shown in the map--that 90 percent of the low-sulfur coal lies in the West and south, while 10 percent lies in the East. Low-Btu gas manufactured from low-sulfur coal may not require desulfurization, resulting in a significant capital saving. This question will be treated in the economics section.

Exhibit III-5 summarizes the major factors relating gasifier performance to coal type.

(3) Characteristics of the output Gases Vary

Significantly and Depend Upon Process Type,

Process Design and Coal Feed

Coal gasification is based on the reaction of coal, an oxidant and steam in a gasifier. Air is the oxidant in low-Btu gasification and oxygen is used in mediumBtu gas production.

1. Low-Btu Gas May Be Used Hot Raw, Detarred and Deoiled, or Clean, Depending. on Feedstook, Operating Conditions and End Use Applications

Hot Raw Gas: Hot raw gas is gas directly out of the gasifier. Most of the entrained ash is removed in cyclones and the remainder settles in the transfer lines. The gas may also have substantial quantities of vaporized oils and tars, unless it is produced from anthracite, in which case it has small amounts of organics. The main advantages of using the hot, raw gas are:

- The sensible heat from the coal oxidation reaction in the gasifier. is ąvailable for use.

- There is a minimum capital investment

- There is no need to use or sell the tars, oils and sulfur resulting , from gas cleaning. 
EXHIBIT III -4

Coalfields of the Coterminous United States

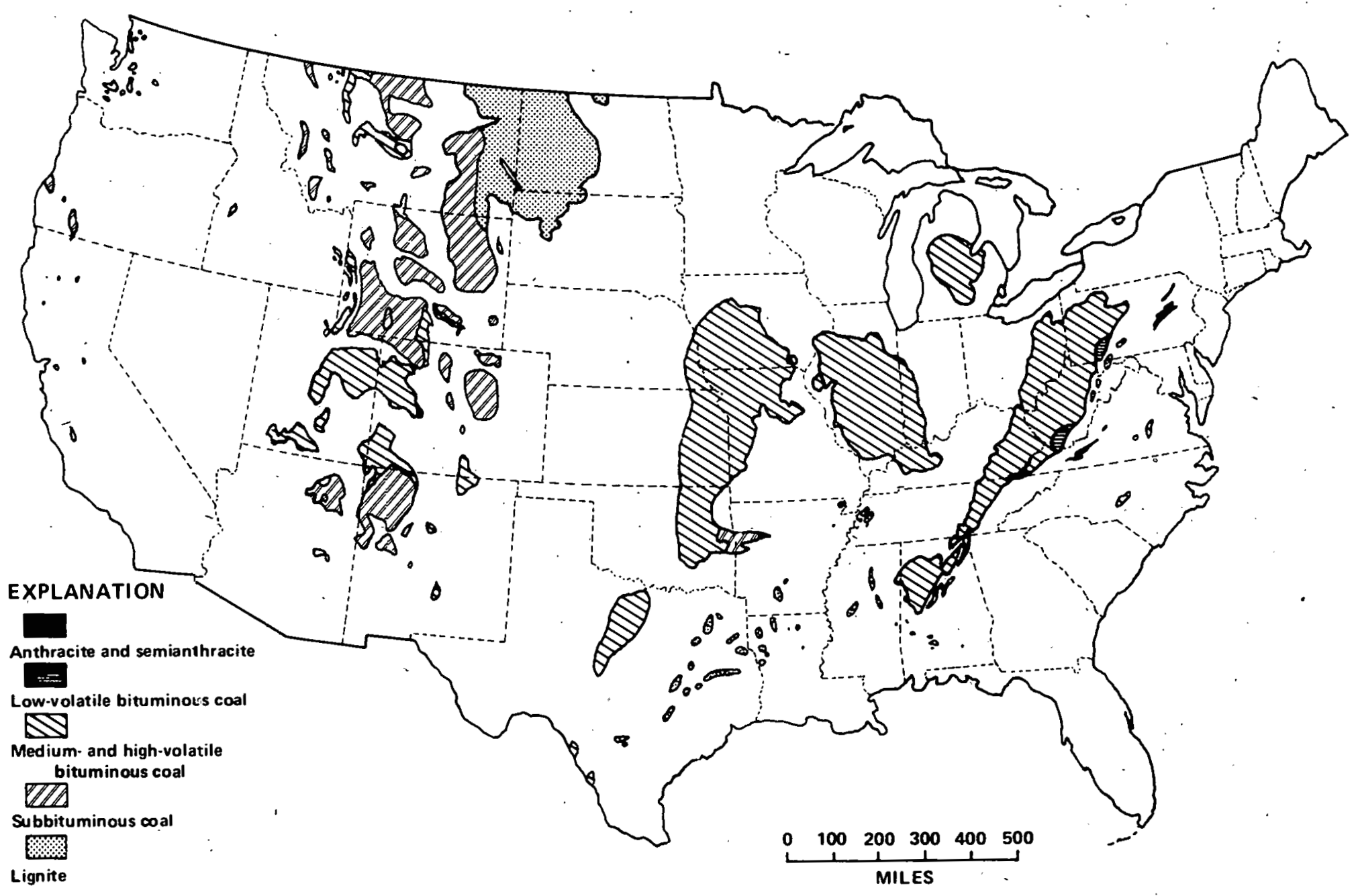




\begin{tabular}{|c|c|c|c|c|}
\hline $\begin{array}{l}\text { COAL RANK AND } \\
\text { DISTRIBUTION }\end{array}$ & $\begin{array}{c}\text { IDENT IF IED RESOURCES } \\
\text { IN GROUND } \\
(106 \text { TONS })\end{array}$ & SMALL LBG USER & LARGE LBG USER & LARGE MBG USER \\
\hline $\begin{array}{l}\text { Anthracites } \\
\text { Pennsylvania } \\
\text { Arkansas } \\
\text { Virginia } \\
\text { Colorado } \\
\text { Narragansett }\end{array}$ & $\begin{array}{r}19,662 \\
18,812 \\
428 \\
335 \\
78 \\
\star *\end{array}$ & $\begin{array}{l}\text { Any small fixed bed gasifier } \\
\text { The higher coal price may be } \\
\text { offset by avoidance of coal } \\
\text { sizing, pretreatment and gas } \\
\text { cleanup. There is, however } \\
\text { a loss in through-put relative } \\
\text { to other coals. } \\
\text { Simplicity of operation }\end{array}$ & $\begin{array}{l}\text { Not the ideal feed for a large } \\
\text { capacity gasifier, but } \\
\text { technically acceptable } \\
\text { No gas cleanup required. }\end{array}$ & $\begin{array}{l}\text { Technically acceptable. } \\
\text { No gas cleanup required. }\end{array}$ \\
\hline $\begin{array}{l}\text { Bituminous } \\
\text { Illinois } \\
\text { W. Virginia } \\
\text { Kentucky } \\
\text { Pennsylvania } \\
\text { Ohio } \\
\text { Indiana }\end{array}$ & $\begin{array}{r}747,357 \\
146,001 \\
100,150 \\
64,346 \\
63,940 \\
41,166 \\
32,184 \\
\end{array}$ & $\begin{array}{l}\text { For medium caking coals a small } \\
\text { fixed bed, single stage gasifier } \\
\text { with mechanical stirring. } \\
\text { No proven process for highly } \\
\text { caking and swelling coals. } \\
\text { Tars, oil and sulfur removal } \\
\text { adds substantially to costs } \\
\text { and complexity, but ability } \\
\text { to feed cheaper high sulfur } \\
\text { coal will reduce cost impact. }\end{array}$ & $\begin{array}{l}\text { Best suited to the entrained } \\
\text { flow gasifiers: Texaco, CE. } \\
\text { Not the best feed for Lurgi or } \\
\text { Winkler; pretreatment may be } \\
\text { required. } \\
\text { No tars \& oils formed with fluidized } \\
\text { bed or entrained flow gasifiers. } \\
\text { Gas desulfurization required. }\end{array}$ & $\begin{array}{l}\text { All appropriate entrained } \\
\text { bed gasifiers: Texaco, } \\
\text { Koppers-Totzek. } \\
\text { Same remarks for Lurgi and } \\
\text { Winkler as for LBG. }\end{array}$ \\
\hline $\begin{array}{l}\text { Sub-Bituminous } \\
\text { Montana } \\
\text { Wyoming } \\
\text { New Mexico } \\
\text { Colorado } \\
\text { Washington }\end{array}$ & $\begin{array}{r}485,766 \\
176,819 \\
123,240 \\
50,639 \\
19,733 \\
4,180\end{array}$ & $\begin{array}{l}\text { Any small fixed-bed gasifier. } \\
\text { Fines formation in the gasifier may } \\
\text { be a problem, especially for two } \\
\text { space gasifiers. } \\
\text { Sulfur removal may become required. }\end{array}$ & $\begin{array}{l}\text { Lurgi and Winkler are well suited. } \\
\text { Texaco had successful runs. } \\
\text { CE still to try the coal. } \\
\text { No gas cleanup needed for fluidized } \\
\text { bed \& entrained flow gasifiers. } \\
\text { Desulfurization may bccome required. }\end{array}$ & $\begin{array}{l}\text { Same comments as for LBG. } \\
\text { Koppers-Totzek suitable. }\end{array}$ \\
\hline $\begin{array}{l}\text { Lignite } \\
\text { N. Dakota } \\
\text { Montana } \\
\text { Texas } \\
\text { S. Dakota }\end{array}$ & $\begin{array}{r}478,134 \\
350,602 \\
112,521 \\
10,293 \\
2,185\end{array}$ & $\begin{array}{l}\text { Depending on the lignite, small fixed } \\
\text { bed gasifiers may encounter diffi- } \\
\text { culties due to lignite's brittleness } \\
\text { (causing fines), its high water con- } \\
\text { tent, and its ash. } \\
\text {, }\end{array}$ & $\begin{array}{l}\text { Both Lurgi and Winkler have } \\
\text { worked well overseas with } \\
\text { lignites. } \\
\text { Lurgi had a successful test } \\
\text { at Sasol with a Texas lignite. }\end{array}$ & $\begin{array}{l}\text { Lurgi and winkler. } \\
\text { Koppers-Totzek. } \\
\text { Texaco has had successful tests. } \\
\text { Coal predrying may be required. }\end{array}$ \\
\hline
\end{tabular}

* Paul Averitt "Coal Resources of the U. S. "January 1970.
** Large Potential 
The process thermal efficiency is typically above 90 percent when using hot raw gas.

- Detarred and Deoiled Gas: This is hot raw gas that is subsequently cooled and washed to remove tars and oils. Further description of this operation is given in paragraph 5 of this section.

Clean Gas (Detarred, Deoiled and Desulfurized): Depending on the amount of sulfur present in the coal and the end use application, the gas cleaning process may require a desulfurization stage. Further discussion of this step' is given in paragraph 5 of this section.

Flow diagrams of the three plant configurations are given in Exhibit III-6. Economic analysis of these systems is presented in section 3 .

2. Medium-Btu Coal Gasification Is Limited to Large Capacity Installations Since It Reguires An Oxygen Plant

The route to produce' medium-Btu gas from coal is the same as that used for low-Btu gas, with oxygen used in place of air. The oxygen, if provided by an oxygen plant, tends to preclude smallscale production of medium-Btu gas since the oxygen plant itself is usually more expensive than the gasifier. The only possibility of avoiding this constraint is where across-the-fence oxygen is sold to the user by an oxygen-producing installation, an existing configuration in at least two smaller U.S. facilities. As a rule, however, MBG requires a large capacity oxygen installation.

3. The Chemical and Physical Characteristics of the Manufactured Gas Are Influenced By the Oxidant, the Feedstock and the operating Conditions

Oxidant: Air is used to produce LBG, resulting in high nitrogen concentrations in the gas, (approximately 50 percent). MBG has higher $\mathrm{H}_{2}$ and $\mathrm{CO}$ concentrations, and significant amounts of $\mathrm{CO}_{2}$, since oxygen is used as a reactant. 
EXHIBIT III-6

Possible Plant Configurations of Small Capacity Gasifiers
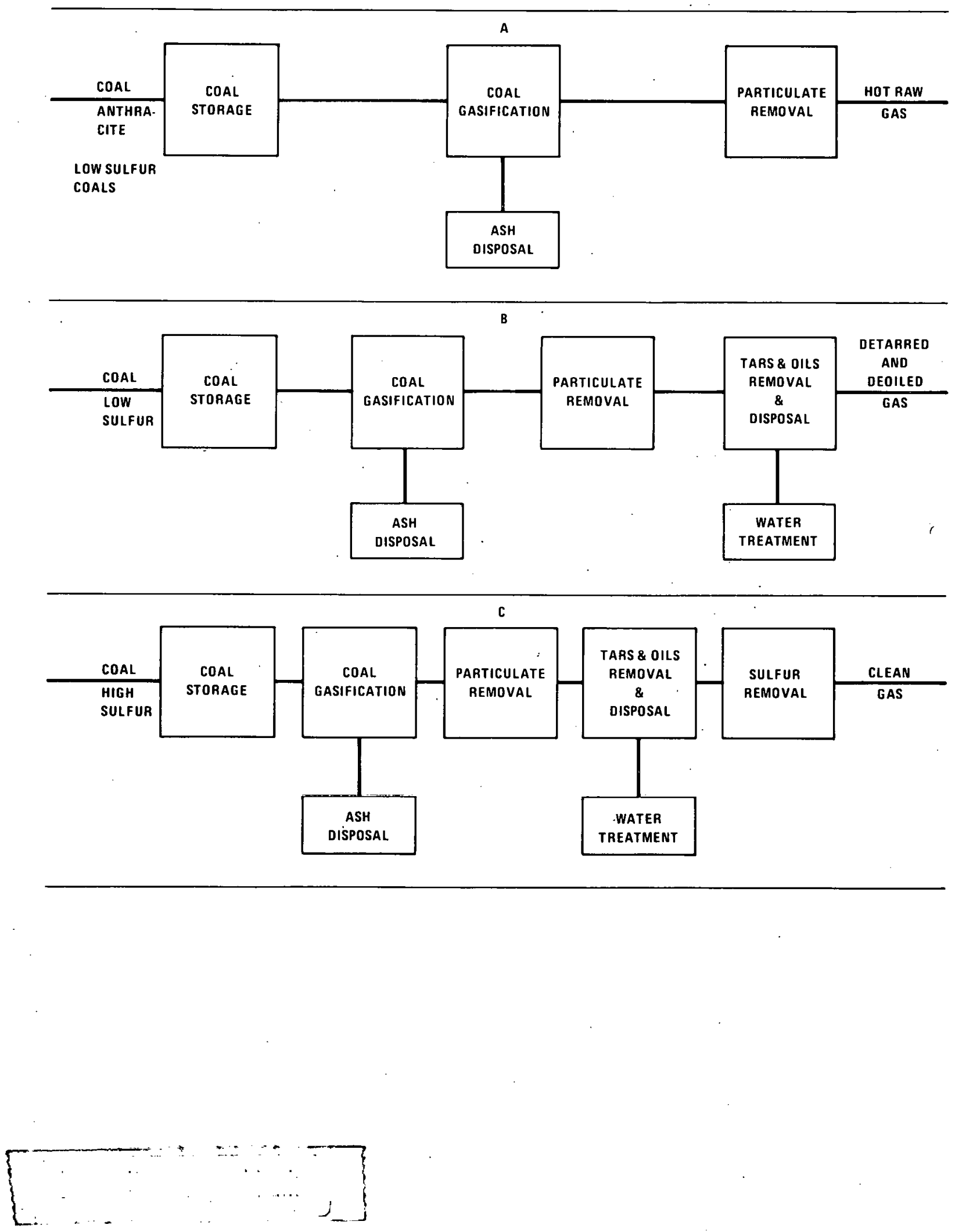
- Feedstock: Gas temperature, other factors being equal, varies with coal type. Sulfur concentration in the coal will determine whether the gas may be used raw or will require treatment. The gas output is proportional to the quality of the input coal.

- Operating Conditions: Different processes produce different $\mathrm{H}_{2} / \mathrm{CO}$ ratios in the gas. Pressurized fixed-bed gasification favors methane formation. High temperature operation tends to reduce the formation of tars and oils.

Exhibit III-7 shows the chemical compositions of LBG and MBG achieved by commercial processes with specific coals. Whereas LBG produced by the various gasifiers shows little variation in composition, the differences in MBG are more pronounced. The practical consequences of gas composition for feedstock and fuel uses are discussed in Chapter $V$.

(4) Utilization of Low-Btu Gas will Require Retrofitting Most Existing Industrial Processes. Medium-Btu Gas Will Require Little Retrofitting

Retrofitting requirements will vary for different technologies and processes, and for different plant configurations within any technology.

Diluents such as nitrogen, carbon dioxide and water vapor present in manufactured gases result in lower heating values and lower flame temperature than natural gas. In the case of MBG, however, high concentrations of $\mathrm{CO}$ and $\mathrm{H}_{2}$, with adlabatic flame temperatures higher than methane, results in a flame temperature close to or higher than that of natural gas, depending on the specific MBG composition. Some of these differences are shown below: 
EXHIBIT III-7

LBG and MBG Compositions

\begin{tabular}{|c|c|c|c|c|c|c|c|c|c|c|c|c|c|c|c|c|c|}
\hline \multirow[t]{2}{*}{ 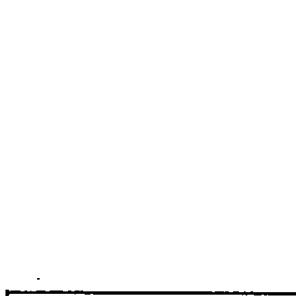 } & & \multicolumn{8}{|c|}{$\begin{array}{l}\text { Gas Composition From Air-Blown Operation (LBG) } \\
\text { (Ory Basis After Scrubbing \& Cooling) }\end{array}$} & \multicolumn{8}{|c|}{$\begin{array}{l}\text { Gas Composition From 0xygen Blown Operation (HBG) } \\
\text { (Ury Basis After Scrubbing \& Cooling) }\end{array}$} \\
\hline & $\begin{array}{c}\text { Gas } \\
\text { Pressure } \\
\text { PSIG }\end{array}$ & $\begin{array}{c}\text { Feed Coal } \\
\text { HHV } \\
\text { BTU/SCF } \\
\text { Dry }\end{array}$ & CO & $\mathrm{CO}_{2}$ & $\mathrm{H}_{2}$ & $\mathrm{CH}_{4}$ & $\begin{array}{l}\mathrm{N}_{2} \\
+^{2} \\
\mathrm{Ar}\end{array}$ & $\mid \begin{array}{c}\mathrm{H}_{2} \mathrm{~S} \\
+ \\
\mathrm{COS} \\
\end{array}$ & $\begin{array}{c}\text { Gas HHV } \\
\text { BTU/SCF } \\
\text { Ory }\end{array}$ & $\begin{array}{l}\text { Feed Coal } \\
\text { HHV } \\
\text { BTU/SCF } \\
\text { Dry }\end{array}$ & CO & $\mathrm{CO}_{2}$ & $\mathrm{H}_{2}$ & $\mathrm{CH}_{4}$ & $\begin{array}{l}\mathrm{N}_{2} \\
\mathrm{AR}\end{array}$ & $\begin{array}{l}\mathrm{H}_{2} \mathrm{~S} \\
+ \\
\mathrm{COS} \\
\end{array}$ & $\begin{array}{c}\text { Gas HHV } \\
\text { BTU/SCF } \\
\text { Ory }\end{array}$ \\
\hline Lurgi & $350-450$ & & & & & & & & & $\begin{array}{l}\text { Pittsburgh } \\
\# 8, \quad 14,900\end{array}$ & 16.9 & 31.5 & 39.4 & 9.0 & 1.6 & 0.8 & 280 \\
\hline Wel1man-Galusha & Atm & Bituminous & 28.6 & 3.4 & 15.0 & 2.7 & 50.3 & & 168 & & & 4 & & & & & \\
\hline Wilput te & & $\begin{array}{l}\text { Anthracite } \\
13,500\end{array}$ & 27.1 & 5.0 & 16.6 & 0.5 & 50.8 & & 146 & & & & & & & & \\
\hline WooJam-Duckham/GI & Atm & ${ }^{\text {HVCB }} 12,900^{\circ}$ & 28.3 & 4.5 & 17.0 & 2.7 & 47.2 & 0.3 & 175 & ${ }_{12,900}^{H V C B}$ & 37.5 & 18.0 & 38.4 & 3.5 & 2.2 & 0.4 & 280 \\
\hline Win<ler & Atm & $\begin{array}{l}\text { W. Sub.Bit. } \\
10,300\end{array}$ & 22.0 & 7.0 & 14.0 & 1.0 & 56.0 & & 126 & $\begin{array}{l}\text { Lignite } \\
10,200\end{array}$ & 48.2 & 13.8 & 35.3 & 1.8 & 0.9 & & 188 \\
\hline Texaco & $300-1200$ & & & & & & & & & $\begin{array}{l}\text { Illinois } \\
\# 6,13,150\end{array}$ & 37.6 & 20.8 & 39.0 & 0.5 & 0.6 & 1.5 & 253 \\
\hline Kopjers-Totzek & $\begin{array}{l}\text { Slightly } \\
\text { Positive }\end{array}$ & & & & & & & & & $\begin{array}{r}\text { Eastern } \\
12,640\end{array}$ & 52.5 & 10.0 & 36.0 & & 1.1 & 0.3 & 286 \\
\hline CE & Atm & $\begin{array}{l}\text { Kentucky } \\
\text { Bit. } \\
12,600\end{array}$ & 22.1 & 7.0 & 17.0 & 0.5 & 53.3 & 0.6 & 127 & & & & & & & & \\
\hline
\end{tabular}

Source: Handbook of Gasifiers and Gas Treatment Systems, Dravo Corporation. 


\begin{tabular}{|c|c|c|c|c|c|c|c|}
\hline & \multirow{2}{*}{$\begin{array}{l}\text { Heating } \\
\text { Value } \\
\text { Btu/scf }\end{array}$} & \multirow{2}{*}{$\begin{array}{l}\text { Flame } \\
\text { Temp. } \\
\text { F }\end{array}$} & \multicolumn{2}{|c|}{$\begin{array}{c}\text { Volumes o } 15 \% \\
\text { scf / Btu }\end{array}$} & \% Excess & \multirow{2}{*}{$\begin{array}{l}\text { Air } \\
\text { Flue } \\
\text { Gas } \\
\end{array}$} & \multirow{2}{*}{$\begin{array}{l}\text { Mixture } \\
\text { Heating } \\
\text { Value } \\
\text { Btu/scf }\end{array}$} \\
\hline & & & Fuel & Air & Mix & & \\
\hline LBG & 153 & 2,853 & 7,043 & 9,860 & 16,903 & 15,790 & 63.8 \\
\hline$M B G$ & 298 & 3,767 & 3,584 & 8,900 & 12,484 & 11,260 & 85.6 \\
\hline Natural Gas & 970 & 3,279 & 1,145 & 12,340 & 13,485 & 13,480 & 82.4 \\
\hline & $\bar{d}$ & $\mathrm{ME}$. & F & 1 , & avo $\mathrm{Cl}$ & pura & $n$ \\
\hline
\end{tabular}

The data show that although there are large differences in heating values between the manufactured gases and natural gas, the differences in heating values among the air-fuel mixtures at the burner are much smaller. Relative to the natural gas-air mix, the LBG-air mix represents a drop of 23 percent and the MBG-air mix comes very close to being equal. These close values are achieved, however, by substantially changing the volumes of the LBG-, MBG-air mix relative to methaneair.

In the LBG-air case, the increase in volume causes a draft loss in the system blowers whlch, cuupled wilh lower heat absorption due to the lower flame temperature, may lead to a significant derating of the boiler or other end use equipment.

In the MBG-air case, however, higher flame temperature and lower flue gas volume may lead to an increase in the rating of the boiler.

Another probable consequence of different air to fuel ratios is the need to introduce mechanlcal changes in the burner system in order to achieve flame stability from changed gaseous flow rates.

The following process and plant characteristics will minimize retrofitting requirements:

- Absence of specific flame shape requirements

Absence of specific combustion or heat release rates, such as those needed in radiant tubes

- Use of low energy gases such as blast furnace, coke oven and low-grade refinery gases 
- Use of large combustion chambers such as boilers and glass melters

- Use of a few large burners instead of many small burners.

(5) The Composition of Byproducts and Emissions Depends on Feedstock Characteristics and Operating Conditions. Environmental Questions Are Not Resolved

Coal gasification, when used with available control technology, is today one of the cleanest ways of utilizing coal. The exact composition of coal gasification byproducts and emissions, however, depends primarily on feedstock characteristics and on operating conditions.

The main environmental concerns regarding coal gasification include:

Particulates: Coal fines disposal may present a problem for small installations where it may not be economical to use briquetting. If a coal-fired boiler is used; these fines may be burned there, otherwise they may have to be returned to the mine.

Ash or Slag: Can be treated and handled the same way as ash from a boiler. It may be sluiced to an ash pond, dumped directly into a container and trucked away, or disposed of by landfill, particularly when a high percentage of carbon is unconverted thus presenting a potentiàl fire hazard.

Nitrogen: Medium-Btu gas contains negligible amounts of nitrogen. Low-Btu, however, contains a large amount (50 percent) due to the air-feed. Nitrogen appears in the gas in the form of molecular nitrogen and a small amount of ammonia. As with sulfur, no nitrogen oxides are formed in the gasifier, but will be formed during combustion. The amount produced, however, is below the "New source Performance standards for Commercial Fuel steam Generator 56 " which prescribes a maximum of $1.26 \mathrm{~g} / 10^{56} \mathrm{cal}$. approximately $1.0 \mathrm{lb} / 10^{6} \mathrm{Btu}$. A low Btu gasifier producing a $4.5 \times 10 "$ Btu/ year is estimated to generate 178 tons/yeaf of NO compounds, equivalent to. $0.791 \mathrm{~b} / 10^{6}$ Btu. 
Sulfur: . The coal's sulfur will appear in the gas mainly as hydrogen sulfide but some also as carbonyl sulfate. Since gasification takes place in a reducing atmosphere, no $\mathrm{SO}_{2}$ is formed. It should be noted, however, that if sulfur-carrying gas is not treated, its combustion will produce $\mathrm{SO}_{2}$. To produce a fuel gas which when burned untreated produces a flue gas with SO contents below EPA standards, the sulfur content in the coal (12,000 Btu/lb) must be no greater than 0.72 percent. Gas desulfurization is usually done in a costly Stretford unit after removing hydrogen cyanide. The main advantage in using a sulfur removal unit is that lower cost, high sulfur coals may be used while meeting EPA SO standards. Tn addition, produrts that may be affected by sulfur oxides can be heated directly by the clean gas. It should be noted that a stretford unit adds complexity, besides cost, to what may have been otherwise a simple system.

- Organic Condensates (Tars and Oils): Are present when gasifiers operate at low temperatures, such as in fixed bed gasifiers. These organirs are remnved by condensation and separation through a water wash and, if needed, an electrostatic precipitator. Tars and oils are profitably separated from the water ard can be used as a fuel or as eliemlcal feedstock. 'lhe water, however, must be treated before discharge since it contains dissolved phenols and ammonia. It would probably be stream stripped and recycled to the quench and water wash sections of the plant. Lurgi gasification, in particular, produces a large amount of condensate, and the required detarring and deoiling results in a significant drop in process thermal efficiency.

Standards affecting coal gasification:technologies are issued or proposed under:

- The clean Air Act

- "Nonattainment" and "Significant Deterioration" provisions of the Clean Air Act amendments 
- The Clean Water Act

- The Toxic Substances control Act

- The Resource Conservation and Recovery Act.

These standards post no insurmountable barriers to the commercial use of coal gasification processes, however: although uncertainties remain in regard to final regulation of these laws.

3. THE ECONOMICS OF COAL GASIFICATION ARE HIGHLY SITUATION-DEPENDENT, WITH OUTPUT GAS COSTS RANGING FROM $\$ 2.70$ TO $\$ 9.60$ PER MILLION BTU

Key factors determining gas cost include:

- Capital cost of the gasification system

- Coal handling and storage costs

- Equipment retrofitting costs

- Delivered cost of coal

- Load factor

- Financing method..

Exc̈luding capital cost of the gasification. system, all other factors are heavily influenced by site or industryspecific conditions. For this reason a general or average synthetic gas cost is of little value for decisionmaking to a potential user of the technology. In order to set up guideposts within :the wide range of possible costs, $\begin{gathered}\text { three } \\ \text { gath }\end{gathered}$ cases were considered for each economic analysis:

- Low cost case, where site-determined contributions to final gas cost are minimized, and low-cost coal was assumed available

- Base case, where an "expected" level of site determined costs is taken into account, and average current coal prices were assumed

- High cost case, where an extensive level of site determined costs is considered, and coal prices were assumed at the upper end of current price ranges.

Results of the analysis are summarized in Exhibit III-8. Key assumptions are provided in Exhibit III-9. The following sections present detailed analysis. 
EXHIBIT III-8

Summary Results: LBG/MBG Economics

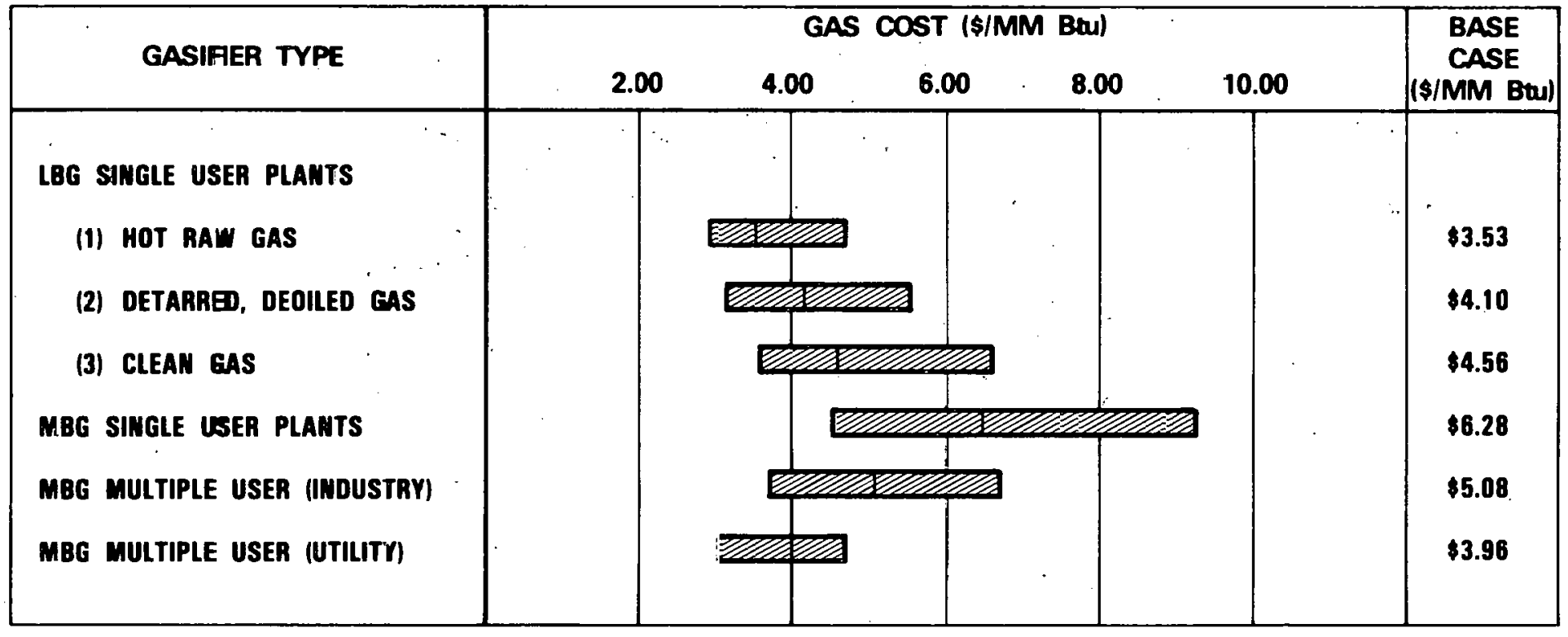

KEY:

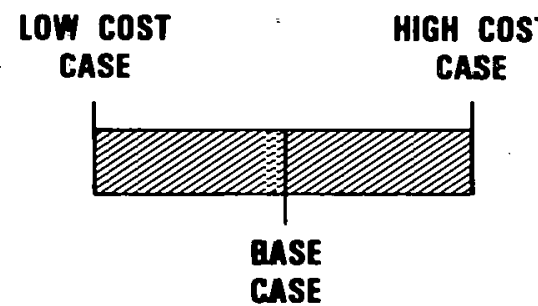


EXHIBIT III-9

Summary of Key Assumptions

(Current Dollars, Mid-1979)

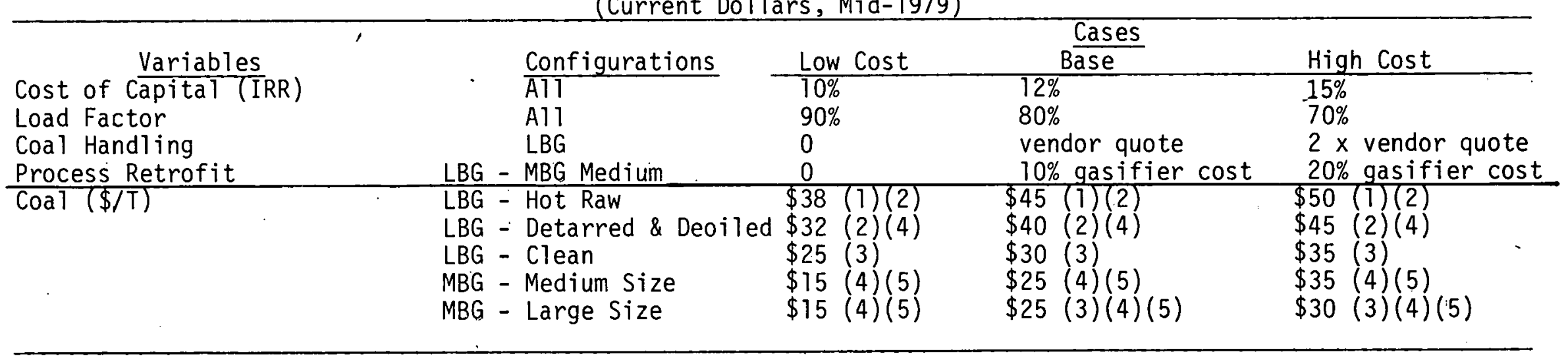

Industry Financing

- A11 Configurations

Utility Financing

- MBG Large Capacity
- 25 year project 1 ife

16 year sum-of-the-years digits depreciation on total plant investment

$100 \%$ equity capital

$20 \%$ investment tax credit

$48 \%$ federal income tax

No operating costs eścalation during project life

- Total plant investment and working capital treated as capital costs at startup completion

- Startup costs treated as an expense at startup completion

- Return on investment during construction treated as capital cost at startup completion

- Result: A constant gas cost (\$/MMBtu) over the life of the project

- 20 year project life

- 5\% straight line on total capital requirement excluding working capital

- Debt $=75 \%$

Interest on debt $=9 \%$

Return on equity $=15 \%$

Return on rate base $=10.5 \%$

No operating cost escalation during project life

o Result: A, constant gas cost (\$/MMBtu) over the 1 ife of the project

(3) High Sulfur Bituminous

(4) Sub-Bituminous

(5) Lignite

. 
(i) A Detailed Analysis Was Conducted Based on Actual Equipment and Coal Costs

The economic analysis is based on cost information contained in the non-site-specific quotations provided by process developers and licensees. Similarly, coal prices are based on prices either being paid by existing users or quoted by coal brokers in spring 1979.

(2) Single-User Low-Btu Gas Is Estimated to Cost Between $\$ 2.70$ and $\$ 6.53$ Per Million Btu

1. Singlë-User, Hot Raw Btu Gas Is Estimated to Cost Between $\$ 2.70$ and $\$ 4.65$ Per Million Btu

Exhibit III-10 shows the capital and operating costs for three different gasifiers, using different coals, with the resulting average gas costs:

Low cost case $=\$ 2.70 / \mathrm{MMBtu}$
Base case $=\$ 3.53 / \mathrm{MMBtu}$
High cost case $=\$ 4.65 / \mathrm{MMBtu}$

The following sensitivities were obtained in the base case:

- Doubling the number of gasifiers lowers the gas cost from 10 to 15 percent; economies of scale become marginal for more gasifiers.

- A coal price change of $\$ 1 /$ Ton in the base case changes the gas cost by approximately $4.5 \% / M M B t u$.

2. Detarred and Deoiled Low-Btu Gas Is

Estimated to Cost Between $\$ 3.03$ and $\$ 5.47$

Per Million Btu. With Byproducts Credits the Costs Drop $\$ 0.55$ Per Million Btu

As shown in Exhibit III-11, detarring and deoiling lowers the Btu output, for the same coal feed rate, by about 10 percent. In addition, the following changes take place relative to the hot raw gas cost structure:

- Capital costs increase by $\$ 700,000$

- Utilities cost double 
EXHIBIT III-10

Costs of Low-Btu: Hot Raw Gas

(Current Dollars)

Hot Raw Gas

\begin{tabular}{|c|c|c|c|c|c|c|c|c|c|}
\hline \multirow[b]{3}{*}{$\begin{array}{l}\text { Gas Output/D (Billion Btu/D) } \\
\text { Load Factor (\%) } \\
\text { Gas Output/Y (Trillion Btu/Y) } \\
\text { Coal Input/D (Tons/D) } \\
\text { Coal Input/Y (Tons/Y) }\end{array}$} & \multicolumn{3}{|c|}{ Low Cost } & \multicolumn{3}{|c|}{ Base } & \multicolumn{3}{|c|}{ High Cost } \\
\hline & A & B & C & A & B & C & A & $\bar{B}$ & $C$ \\
\hline & $\begin{array}{r}1.1 \\
90 \\
0.36 \\
48 \\
15,768\end{array}$ & $\begin{array}{r}1.7 \\
90 \\
0.53 \\
23,652\end{array}$ & \begin{tabular}{r|}
1.3 \\
90 \\
0.43 \\
60 \\
19,710
\end{tabular} & $\begin{array}{r}1.1 \\
. \quad 80 \\
0.32 \\
48 \\
14,016\end{array}$ & $\begin{array}{r}1.7 \\
80 \\
0.47 \\
72 \\
21,024\end{array}$ & $\begin{array}{r}1.3 \\
80 \\
0.38 \\
60 \\
18,520\end{array}$ & $\begin{array}{r}1.1 \\
70 \\
0.28 \\
48 \\
12,264\end{array}$ & $\begin{array}{r}7.6 \\
70 \\
0.41 \\
72 \\
18,396\end{array}$ & $\begin{array}{r}7.6 \\
70 \\
0.33 \\
60 \\
15,330\end{array}$ \\
\hline $\begin{array}{l}\text { Gasification (\$MM) } \\
\text { Coal Hnalding (\$MM) } \\
\text { Retrofitting (\$MM) } \\
\text { Work. Capital (\$MM) } \\
\text { Startup (\$MM) } \\
\text { Total Capital Costs (\$MM) }\end{array}$ & $\begin{array}{l}1.54 \\
-- \\
-- \\
0.11 \\
0.13 \\
1.78\end{array}$ & $\begin{array}{l}1.50 \\
-- \\
-- \\
0.18 \\
0.22 \\
1.90\end{array}$ & $\begin{array}{c}1.36 \\
-- \\
-- \\
0.14 \\
0.17 \\
1.67\end{array}$ & $\begin{array}{l}1.54 \\
0.15 \\
0.15 \\
0.12 \\
0.14 \\
2.10\end{array}$ & $\begin{array}{l}1.50 \\
0.26 \\
0.15 \\
0.19 \\
0.23 \\
2.33\end{array}$ & $\begin{array}{l}1.36 \\
0.36 \\
0.15 \\
0.15 \\
0.18 \\
2.20\end{array}$ & $\begin{array}{l}1.54 \\
0.30 \\
0.30 \\
0.11 \\
0.14 \\
2.39\end{array}$ & $\begin{array}{l}1.50 \\
0.52 \\
0.30 \\
0.19 \\
0.22 \\
2.73\end{array}$ & $\begin{array}{l}1.36 \\
0.72 \\
0.30 \\
0.14 \\
0.17 \\
2.69\end{array}$ \\
\hline $\begin{array}{l}\text { Coal Type } \\
\text { Coal Price }(\$ / T) \\
\text { Coal Costs } / Y^{\prime}(\$) \\
\text { O \& M }(\$) \\
\text { Utilities }(\$) \\
\text { Miscellaneous }(\$) \\
\text { total Operating Costs }(\$)\end{array}$ & $\begin{array}{c}\text { Anthracit } \\
38 \\
599,184 \\
45,000 \\
10,000 \\
20,000 \\
674,184\end{array}$ & $\begin{array}{r}\text { e or Low-S B } \\
38 \\
898,77.6 \\
156,000 \\
19,000 \\
22,000 \\
1,095,776\end{array}$ & $\begin{array}{r}\text { ituminous } \\
38 \\
748,980 \\
66,000 \\
20,000 \\
20,000 \\
854,980\end{array}$ & $\begin{array}{c}\text { Anthracit } \\
45 \\
630,720 \\
45,000 \\
10,000 \\
20,000 \\
705,720\end{array}$ & $\begin{array}{r}\text { or Low-S B } \\
45 \\
946,080 \\
156,000 \\
19,000 \\
22,000 \\
1,143,080\end{array}$ & $\begin{array}{r}\text { ituminous } \\
45 \\
788,400 \\
66,000 \\
20,000 \\
20,000 \\
894,400\end{array}$ & $\begin{array}{r}\text { Anthraci } \\
50 \\
613,200 \\
45,000 \\
-10,000 \\
\frac{20,000}{688,200}\end{array}$ & $\begin{array}{c}\text { te or Low-S } \\
50 \\
919,000 \\
156,000 \\
19,000 \\
22,000 \\
1,116,800\end{array}$ & $\begin{array}{r}\text { Bituminous } \\
50 \\
766,500 \\
66,000 \\
20,000 \\
20,000 \\
872,500\end{array}$ \\
\hline $\operatorname{IRR}(\%)$ & 10 & 10 & 10 & 12 & 12 & 12 & 15 & 15 & 15 \\
\hline $\begin{array}{l}\text { Gas Cost: }(\$ / M M B t u) \\
\text { - Coal Cost } \\
\text { - Other Operating } \\
\text { - Capital Charge } \\
\text { Total Gas Cost = }\end{array}$ & $\begin{array}{l}1.66 \\
0.21 \\
0.87 \\
2.74\end{array}$ & $\begin{array}{l}1.70 \\
0.37 \\
0.62 \\
2.69\end{array}$ & $\begin{array}{l}1.74 \\
0.25 \\
0.67 \\
2.66\end{array}$ & $\begin{array}{l}1.97 \\
0.23 \\
1.38 \\
3.58\end{array}$ & $\begin{array}{l}2.01 \\
0.42 \\
1.02 \\
3.45\end{array}$ & $\begin{array}{l}2.07 \\
0.28 \\
1.20 \\
3.55\end{array}$ & $\begin{array}{l}2.19 \\
0.27 \\
2.25 \\
4.71\end{array}$ & $\begin{array}{l}2.24 \\
0.48 \\
1.73 \\
4.45\end{array}$ & $\begin{array}{l}2.32 \\
0.32 \\
2.174 \\
4.78\end{array}$ \\
\hline Average Cost $=$ & & 2.70 & & & 3.53 & & & 4.65 & \\
\hline
\end{tabular}

Key: $A, B ; C$ represent different gasifiers 
EXHIBIT III-11

Costs of Low-Btu: Detarred and Deoiled Gas

(Current Dollars)

Gas Output (Bil Btu/D)

Load Factor (\%)

Gas Output (Trill Btu/Y)

Coal Input (Tons/D)

Coal Input (Tons/Y)

Gasification System (\$MM)

Coal Handling (\$MM)

Retrofitting (\$MM)

Tar Removal (\$MM)

Working Capital (\$MM)

Startup Costs (\$MM)
Total Capital Costs (\$MM)

Coal Type

Coal Price $(\$ / T)$

Coal Costs $/ Y(\$)$.

0 \& $M(\$)$

Utilities (\$)

Miscellaneous (\$)

Total Operating

Costs $(\$)$

IRR (\%)

Gas Cost: ( $\$ / M M B t u)$

- Coal Cost

- Other Operating

- Capital Charge

Total Gas Cost =

Average Cost $=$

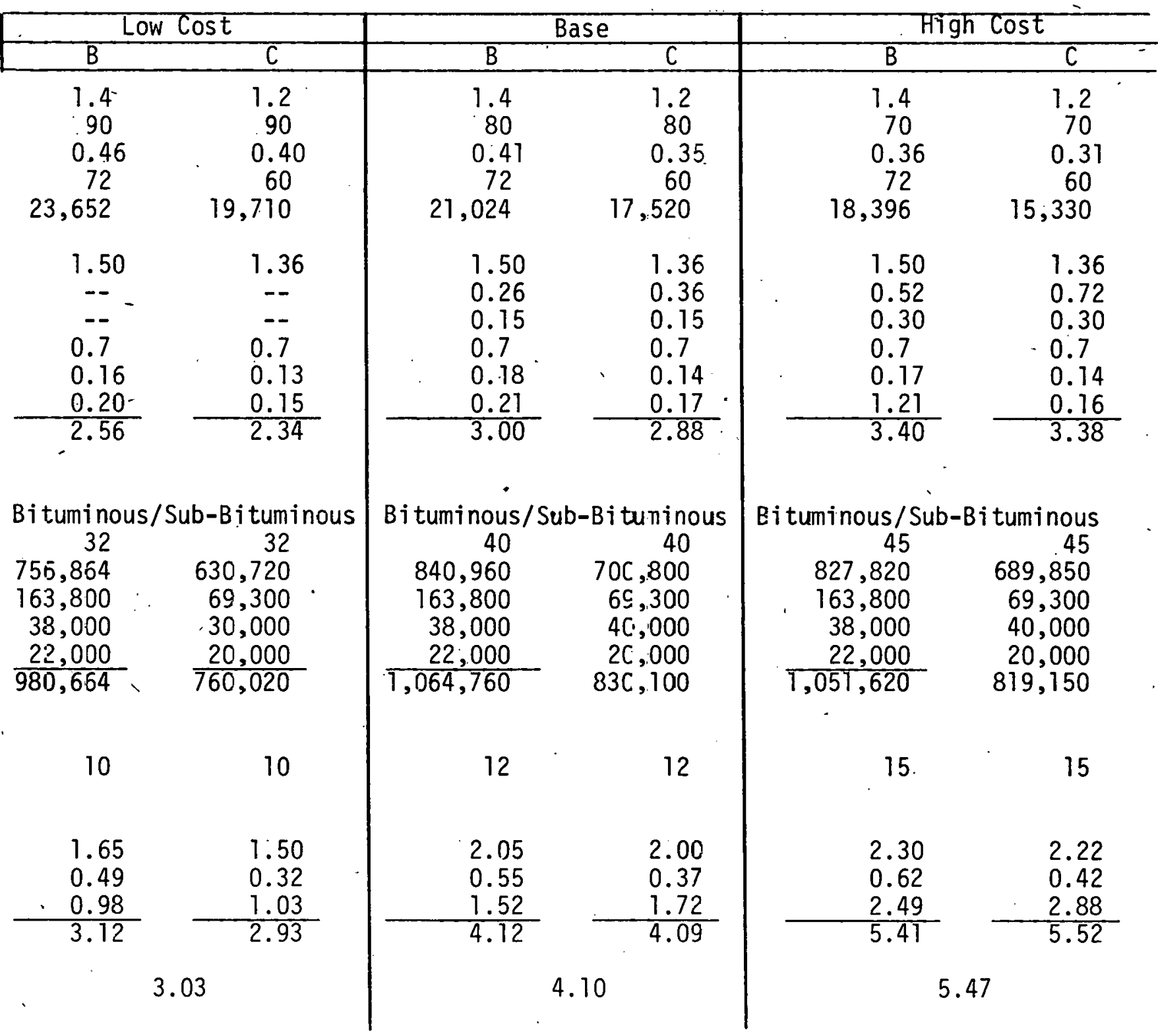

Key: $B$ and $C$ are the same gasifiers as in Exhibit III-10 
- Operations and maintenance costs increase by 5 percent.

The net result is to increase average gas costs to:

$$
\begin{aligned}
& \text { Low cost case }=\$ 3.03 / \mathrm{MMBtu} \\
& \text { Base case }=\$ 4.10 / \mathrm{MMBtu} \\
& \text { - Highrcost case }=\$ 5.47 / \mathrm{MMBtu}
\end{aligned}
$$

If a byproduct credit of $\$ 250,000 /$ year is given for the tars/oils recovered and sold, this reduces the gas cost by approximately $\$ 0.55 / \mathrm{MmBtu}$. This figure, however, does not include byproduct handling, transportation and selling costs.

3. Clean Low-Btu Gas Is Estimated to cost Between $\$ 3.39$ and $\$ 6.28$ Per Million Btu. With Byproducts Credits the Costs Drop By \$0.60 Per Million Btu

As shown in Exhibit III-12, desulfurizing the detarred and deoiled gas introduces the following changes relative to the detarred and deoiled gas cost structure:

- Capital increases from $\$ 1 \mathrm{MM}$ to $\$ 2 \mathrm{MM}$ depending on the desulfurization process and contractor

- Utilities cost double

- Operations and maintenance increase by 12 percent.

The net result is to increase the average gas costs to:

$$
\begin{aligned}
& \text { Low cost case }=\$ 3.39 / \mathrm{MMBtu} \\
& . \quad \text { Base case }=\$ 4.56 / \mathrm{MMBtu} \\
& \text { High cost case }=\$ 6.28 / \mathrm{MMBtu} .
\end{aligned}
$$

If a byproduct credit of $\$ 275,000 /$ year is given for the tars/oils and sulfur recovered and sold, this reduces the gas costs by approximately $\$ 0.60 / \mathrm{MmBtu}$. This figure does not include byproduct handing, transportation and delivery costs. In addition, it shoüld be noted that cleaning the hot raw gas from" a small fixed bed gasifier increases the operating complexity of the system by: 
EXHIBIT III-12

Costs of Low-Btu: Clean Gas

(Current Dollars)

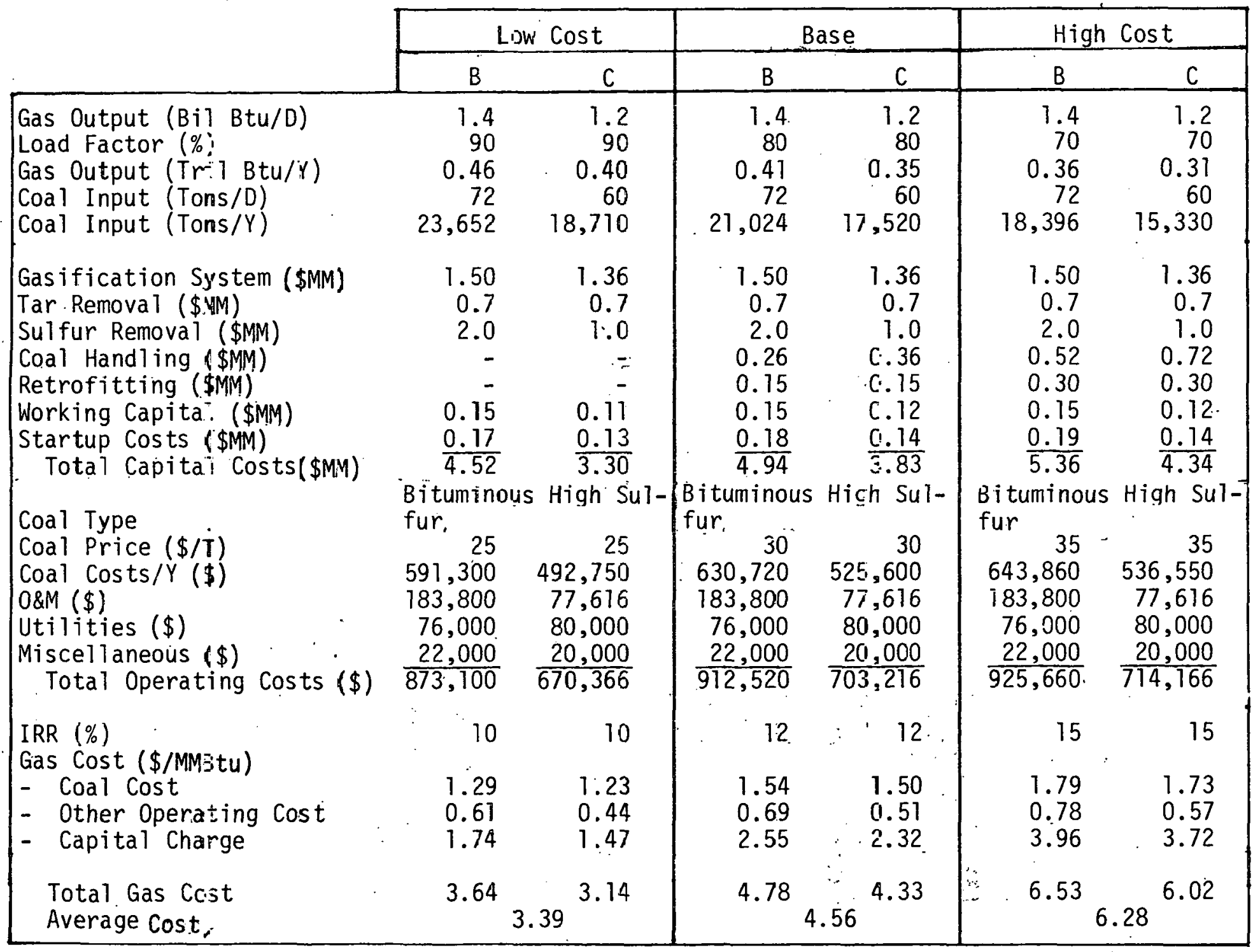

Key̆: $B$ and C are tine same gasifiers as in Exhibits III-II and III-12 
- Making gasification on-stream factor depend on clean up subsystem reliability

- Requiring skilled labor to operate clean up units.

These constraints may be important to some users who already operate at a high level of technical and organizational complexity, but may have, for others, an impact greater than what the cost figures alone show.

(3). Medium-Btu Gas Is Estimated to Cost Between $\$ 3.00$ and $\$ 9.33$ Per Million Btu, Depending on Plant Scale and Financing

The economics of two medium-Btu gas plant configurations were analyzed:

Large capacity, multiple-user facility, using industrial and utility financing schemes

Medium capacity, single-user operation, based on industrial financing.

1. Large, Multiple-User Medium-Btu Gas Costs Between $\$ 3.59$ and $\$ 6.68$ Per Million Btu If Industry Owned, and Between $\$ 3.00$ and $\$ 4.55$ Per Miliion Btu If Utility Owned

Exhibit III-13 shows the capital costs and operating costs for two different processes, using different coals, with resulting average gas costs.

$\begin{array}{lcc} & \begin{array}{c}\text { Industrial } \\ \text { Financing }\end{array} & \begin{array}{c}\text { Utility } \\ \text { Financing }\end{array} \\ \text { Low cost case } & \$ 3.59 / \mathrm{MMBtu} & \$ 3.00 / \mathrm{MMBtu} \\ \text { Base case } & \$ 5.08 / \mathrm{MMBtu} & \$ 3.96 / \mathrm{MMBtu} \\ \text { High cost case } & \$ 6.68 / \mathrm{MMBtu} & \$ 4.55 / \mathrm{MMBtu}\end{array}$

It should be noted that neither industrial financing nor utility financing gas costs include gas transportation or retrofitting costs, which 
EXHIBIT III-13

Costs of Large MBG: Multiple-User Facility

(Current Dollars)

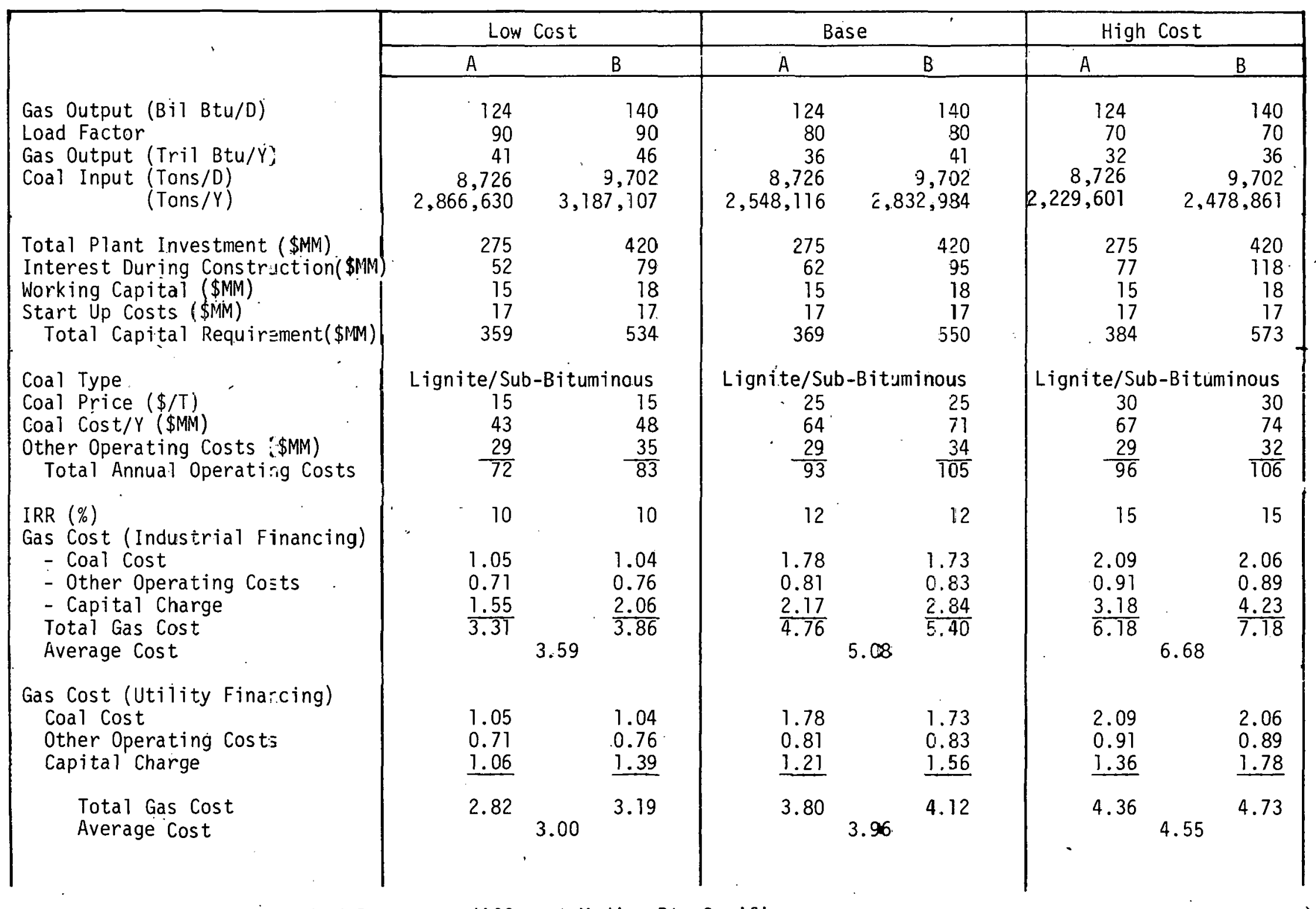

Key: $A$ and $B$ are two different Medium-Btu Gasifiers 
will be functions of location relative to central gas plant and of the user existing process configuration. For chemical feedstock, gas transportation will be the only additional cost.

2. Single-User, Medium-Btu Gas Is Estimatéd to Cost Between $\$ 4.31$ and $\$ 9.33$ Per Million Btu

Based on the large capacity plant information, capital costs for medium sized plants were derived from the empirical relationship of economies of scale for chemical processes:

$$
c_{1}=x^{0.7} c_{2}
$$

$C_{1}=$ unknown capital cost

$\mathrm{C}_{2}^{1}=$ known capital cost

$r^{2}=$ ratio of plant capacities

Operating costs were derived using a linear relationship.

Exhibit III-14 shows the capital costs and operating costs for the two processes, with resulting average costs:

$$
\begin{aligned}
& \therefore \quad \text { Low cost case }=\$ 4.31 / \mathrm{MMBtu} \\
& \text { Base case }=\$ 6.28 / \mathrm{MMBtu} \\
& \text { High cost case }=\$ 9.33 / \mathrm{MMBtu} .
\end{aligned}
$$

(4) Economic Analysis Shows Clearly That the Attractiveness of LBG and MBG Depends on the Specific Industrial situation

Exhibit III-15 shows the gas costs for the cases analyzed and compares each case with the present (mid1979) delivered prices of natural gas ( $\$ 2.75 / \mathrm{MMBtu})$ and of Number 2 fuel oil ( $\$ 3.75 / \mathrm{MMBtu})$. It may be concluded that:

Under a high cost scenario no industrial fuel gas is competitive with either natural gas or Number 2 fuel oil

Under base case assumptions, no industrial fuel gas is competitive with natural gas. However, 
EXHIBIT III-14

Costs of Medium-Sized MBG: Single-User Facility

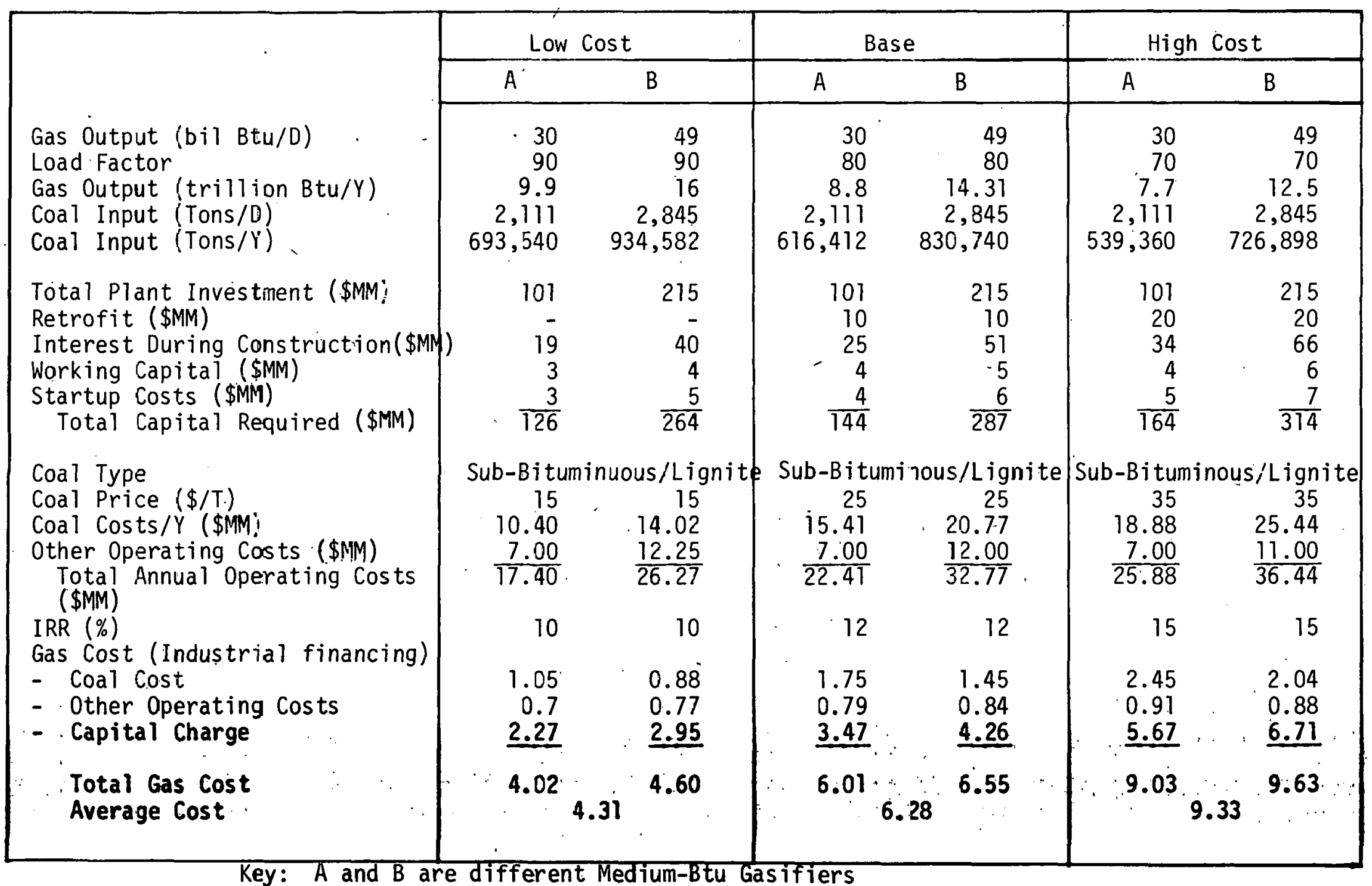

Key: $A$ and $B$ are different Medium-Btu Gasifiers 


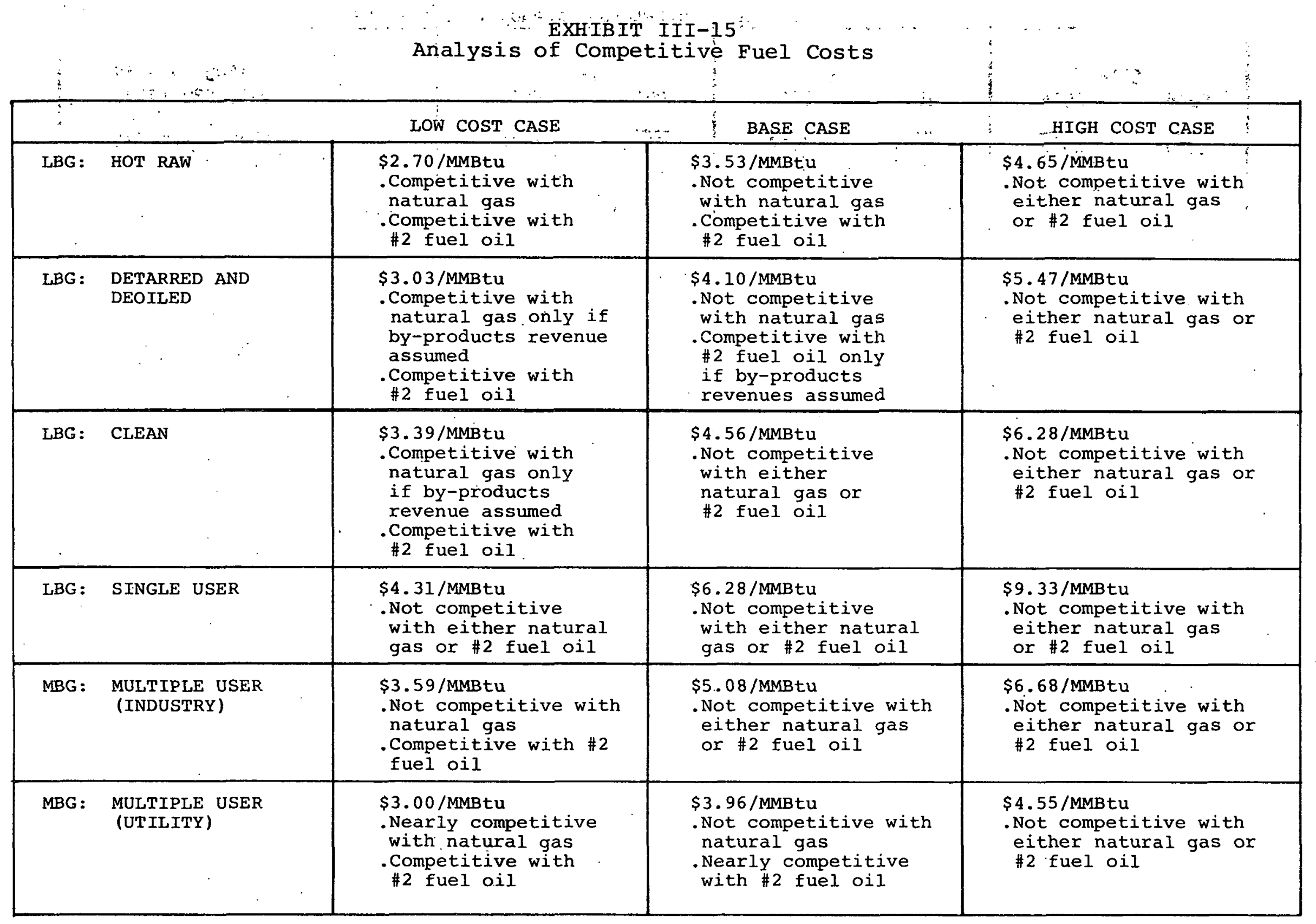


- LBG hot: raw gas competes with Number 2 fuel oil

- LBG detarred and deoiled gas competes with Number 2 fuel oil if byproducts revenue is assumed

- MBG multiple-user gas is nearly competitive. with Number 2 fuel oil.

Under a low cost scenario, all industrial fuel gases with the exception of MBg single-user complete with Number 2 fuel oil. In addition

- LBG hot raw gas is competitive with natural gas

- LBG detarred and deoiled gas, and LBG clean compete with natural gas if byproducts revenue is assumed

- MBG multiple-user gas, with utility financing, is nearly competitive with natural gas.

The attractiveness of industrial gases relative to natural gas and Number 2 fuel oil under 1985 projected prices will be considered later in this report.

This chapter has analyzed commercially-available coal gasifier technologies, the key factors involved in gasifier equipment application, and the economics of gasifier systems. The following chapter examines, in-depth, IBG and MBG gasifier applications presently under or near operation in the U.S. 
IV. ANALYSIS OF PRESENT U.S. INDUSTRIAL APPLICATIONS

OF LOW- AND MEDIUM-BTU GASIFICATION 
IV. ANALYSIS OF PRESENT U.S. INDUSTRIAL APPLICATIONS

OF LOW- AND MEDIUM-BTU GASIFICATION

This chapter presents an assessment of current industrial applications and users of coal gasification. The assessment is in four parts:

- Brief historical background

- Documentation of current gasifier projects

- Assessment of owner's motivations

- Current users' outlook on the near-term market and government role.

1. INDUSTRIAL COAL GASIFICATION PEAKED IN THE 1920'S, WITH THE MAJORITY OF GASIFIERS OPERATING IN THE STEEL INDUSTRY

The manufacture of low-Btu producer gas from:coal was becoming widespread in the United States in the early $1920^{\prime} \mathrm{s}$. The peak was reached about 1925 when approximately 11,000 * low-Btu gasifiers were in use. Exhibit IV-1 shows that the industrial fuel gas requirements commanded about 90 percent of the gasifiers; only about 10 percent were used for town lighting.

Subsequently, with the development of the national natural gas pipeline system and resulting low-cost natural gas, the use of coal gasification diminished. Most of the coal gasifiers were abandoned in the 1940's and 1950's.

2. TODAY THERE ARE AT LEAST 20 INDUSTRIAL GASIFIER PROJECTS IN OPERATION, START-UP, CONSTRUCTION, OR PLANNING PHASES IN THE U.S. THERE ARE ALSO A LARGE NUMBER OF KNOWN FOREIGN GASIFIERS

Field investigations during the course of the study revealed more gasification projects than previously described

* Assessment of Low- and Intermediate Gasification of Coal, National Research Council, 1977. 


\begin{tabular}{|c|c|c|}
\hline Application & Number & Percent \\
\hline Steel Plants & 6,500 & $59 \%$ \\
\hline Glass Plants & $1 ; 500$ & $14 \%$ \\
\hline $\begin{array}{l}\text { Ceramics and Lime- } \\
\text { Burning Plants }\end{array}$ & 1,500 & $14 \%$ \\
\hline Gas Utilities. & 1,000 & $9 \%$ \\
\hline $\begin{array}{l}\text { Metallurgical and } \\
\text { Chemical Plants }\end{array}$ & 500 & $4 \%$ \\
\hline Total & 11,000 & $100 \%$ \\
\hline
\end{tabular}


in the literature. Of the 23 active projects in the U.S., summarized in Exhibit IV-2:

Six are in operation

Five are undergoing check-out tests with full

operation planned for later this year

Four are in, or soon to be in, construction

Eight are in advanced planning stages.

The succeeding sections describe commercial and governmentsponsored low- and medium-Btu projects in the following categories:

- U.S. industry-funded gasifier projects

- U.S. government-sponsored gasifier projects

- Foreign gasifier projects.

(1) - In the United States 13 Current Gasifier Projects Have Been Idnetified Which Are Funded By Industry, 5 of Which Are in Full Operation

There are five industrial companies in the United States presently gasifying coal or coke to make a lowor medium-Btu fuel. In operation are 12 individual gasifiers, most of which are Wellman-Galusha units based on 1930 technology, as indicated by the project summaries in Exhibit IV-3.

1. Brick, Chemical and Limestone Companies Are Currently Using Coal Gasification in Their Processes

The company with the longest experience in coal gasification is the Glen-Gery Corporation, Reading, Pennsylvania, a brick manufacturer.

Their initial gasifiers were installed in 1953, but were shut down at various times due to the availability of cheaper natural gas. They were reactivated over the past few years because of gas curtailments and higher natural gas prices.

Similarly the Hazleton Brick Company, Hazleton, Pennsylvania, has reactivated its 1953 installed LBTU gasifier. Both of these companies use Pennsylvania anthracite coal as feedstock, producing a gas low in sulfur and hydrocarbon content without the necessity of expensive cleanup equipment. 
EXHEBIT IV-2

Summary of Indistrial Gasification Projects

Spring 1979

\begin{tabular}{|c|c|c|c|c|c|c|}
\hline Source & Funding & Operater & $\begin{array}{l}\text { Initial } \\
\text { Start-Up }\end{array}$ & Gas & Coal & Facility \\
\hline Operating & $\begin{array}{l}\text { PRV } \\
\text { PRV/DOE } \\
\text { DOD } \\
\text { PRV } \\
\text { PRV } \\
\text { PRV }\end{array}$ & $\begin{array}{l}\text { National Lime \& Stone Cimpany (Ohio) } \\
\text { Glen-Gery Corporation (PA)1 } \\
\text { Hclston Defense Compcration. (IN) } \\
\text { Hazleton Brick Compariy (PA) } \\
\text { Gulf \& Western (N.J. Zinc) (Pr) } \\
\text { olin Chemical Corporction (Ohio) }\end{array}$ & $\begin{array}{l}1955 \\
1953 / 1977 \\
1940 \\
1953 / 1978 \\
1963 \\
1963\end{array}$ & $\begin{array}{l}\angle B G \\
\angle B G \\
\angle B G \\
\angle B C \\
C O^{* *} \\
C O^{* \star}\end{array}$ & $\begin{array}{l}\text { Bituminous } \\
\text { Antiracite } \\
\text { Bituminous } \\
\text { Antirracite } \\
\text { Coke } \\
\text { Coke }\end{array}$ & $\begin{array}{l}2 \text { WG } \\
7 \text { WG } \\
12 \text { Wilputte } \\
3 \text { WG } \\
W G \\
W G\end{array}$ \\
\hline Start-U? & $\begin{array}{l}\text { PRV } \\
\text { PRV } \\
\text { PRV } \\
\text { DOE/PRV } \\
\text { EPA/FRV }\end{array}$ & $\begin{array}{l}\text { Caterpillar Tractor Company }(\Sigma A) \\
\text { General Motors Corjoration (Mich.) } \\
\text { Dow Cremical Compayy (LA) } \\
\text { Uriversity of Minnesota (Minn.) } \\
\text { Central Power: \& Light (Texas) }\end{array}$ & $\begin{array}{l}1979 \\
1979 \\
1979 \\
1979 \\
1979\end{array}$ & 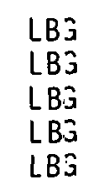 & $\begin{array}{l}\text { Bituminous } \\
\text { Various } \\
\text { Lignite } \\
\text { Various } \\
\text { Lignite }\end{array}$ & $\begin{array}{l}2 \text { WI } \\
\text { Stoic } \\
\text { Texaco } \\
\text { Stoic } \\
\text { Foster Wheeler }\end{array}$ \\
\hline Construction & $\begin{array}{l}\text { PRV } \\
\text { PRV } \\
\text { DOE/FRV } \\
\text { TVA }\end{array}$ & 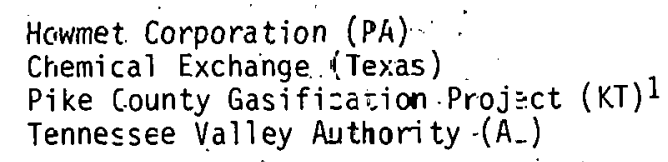 & $\begin{array}{l}1979 \\
1979 \\
1980 \\
1980\end{array}$ & $\begin{array}{l}\text { LBG } \\
\text { LBS } \\
\text { LBG } \\
\text { MBG }\end{array}$ & $\begin{array}{l}\text { Anthracite } \\
\text { Ligmite } \\
\text { Bituminous } \\
\text { Bituminous }\end{array}$ & $\begin{array}{l}W G \\
W G \\
2 W G \\
\text { Texaco }\end{array}$ \\
\hline Design & 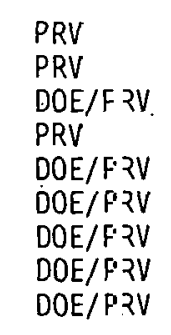 & 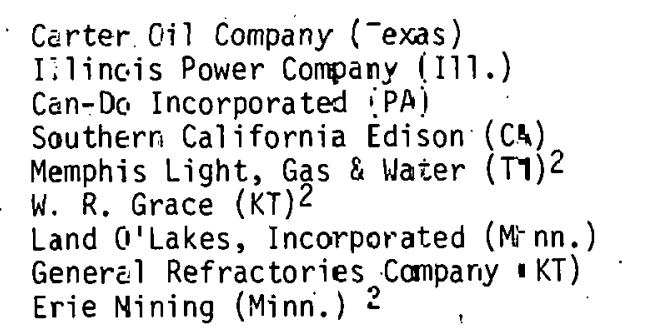 & $\begin{array}{l}1987^{\star} \\
1982 \\
1980 \\
1980 \\
1982 \\
1982 \\
\text { Cancelled } \\
\text { Cancelled } \\
\text { Cancelled }\end{array}$ & $\begin{array}{l}\text { MBG } \\
\text { LBG } \\
\text { LBG } \\
\text { NBG } \\
\text { MBG } \\
\text { MBGG }\end{array}$ & $\begin{array}{l}\text { Ligni te } \\
\text { Bituminous } \\
\text { Anthracite } \\
\text { Bituminous } \\
\text { Bituminous } \\
\text { Bitumirous }\end{array}$ & $\begin{array}{l}\text { Lurgi } \\
\text { Allis } \\
2 \text { WG } \\
\text { Texaco } \\
\text { Foster Wheeler } \\
\text { Texaco }\end{array}$ \\
\hline Key: $\begin{aligned} \star & = \\
\star \star & = \\
W G & = \\
h I & = \\
h D & = \\
\text { PRV } & =\end{aligned}$ & $\begin{array}{l}\text { stimated } \\
\text { oke Fuels } \\
\text { lellman aal } \\
\text { lellman Inc } \\
\text { loodall-Duc } \\
\text { rivate }\end{array}$ & escent & \multicolumn{4}{|c|}{$\begin{array}{l}1=\text { Federal Gasifiers in Industry Program } \\
2=\text { Federal Fuel Gas Demorstration Program } \\
3=\text { Industriai Test/Demonstration }\end{array}$} \\
\hline
\end{tabular}


EXHIBIT IV-3

Status of Industry-Funded

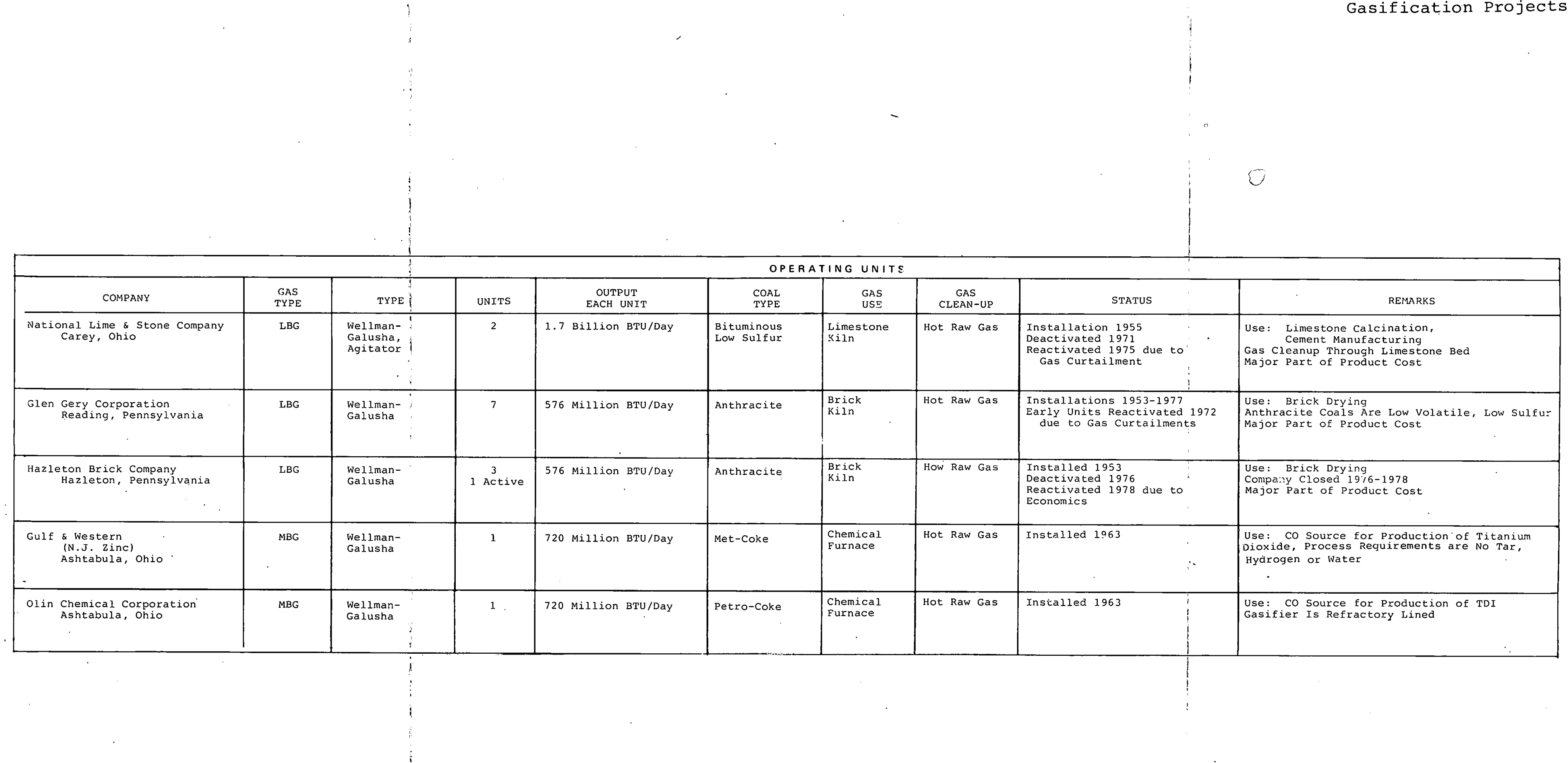




\begin{tabular}{|c|c|c|c|c|c|c|c|c|c|}
\hline \multicolumn{10}{|c|}{ CONSTRUCTION/CHECKOUT UNITS } \\
\hline COMPANY & $\underset{\text { TYPE }}{\text { GAS }}$ & TYPE & UNITS & $\underset{\text { EACH UNIT }}{\text { OUTPUT }}$ & $\begin{array}{l}\text { COAL } \\
\text { TYPE }\end{array}$ & $\begin{array}{l}\text { GAS } \\
\text { USE }\end{array}$ & $\underset{\substack{\text { GAS } \\
\text { CLEAM-UP }}}{\text { C. }}$ & status & REMARKS \\
\hline $\begin{array}{l}\text { Caterpiller Tractor Company } \\
\text { York, Pennsylvania }\end{array}$ & LBG & $\begin{array}{l}\text { Wellman- } \\
\text { Incandescent }\end{array}$ & 12 & 1.25 Billion BTU/Day & $\begin{array}{l}\text { Bituminous } \\
\text { High Sulfur }\end{array}$ & $\begin{array}{l}\text { Metal } \\
\text { Processing } \\
\text { Furnace }\end{array}$ & $\begin{array}{l}\text { Cold clean } \\
\text { De-tar } \\
\text { De-sulfur }\end{array}$ & $\begin{array}{l}\text { Construction Decision } 1976 \\
\text { Start-up Planned June } 1979\end{array}$ & $\begin{array}{l}\text { Use: Carbonizing Heat Treat Furnace } \\
\text { Decision Driver-Fuel Security } \\
\text { Minor Part of Product Cost }\end{array}$ \\
\hline $\begin{array}{l}\text { General Motors Corporation } \\
\text { Saginaw, Michigan }\end{array}$ & LBG & $\begin{array}{l}2 \text { Stage } \\
\text { Stoic }\end{array}$ & $i$ & 36 Million BTU/Day & variety & $\begin{array}{l}\text { Metal } \\
\text { Processing } \\
\text { Furnace }\end{array}$ & $\begin{array}{l}\text { Cold clean } \\
\text { De-tarred }\end{array}$ & $\begin{array}{l}\text { Start-up Planned May } 1979 \\
\text { Checkout Started October } 1978\end{array}$ & $\begin{array}{l}\text { Use: Heat Treat Furnace } \\
\text { Pilot plant } \\
\text { Testing } 7 \text { Types of Coal } \\
\text { Gasifier Received on Skid, wired and } \\
\text { Plumbed, } \$ 93,000\end{array}$ \\
\hline $\begin{array}{l}\text { Dow Chemical Company } \\
\text { Plaquemine, Jouisiana }\end{array}$ & LBG & Texaco & $1 \quad 1$ & Unknown & $\begin{array}{r} \\
\text { Lignite } \\
\vdots\end{array}$ & $\begin{array}{l}\text { Electrical } \\
\text { - Generation }\end{array}$ & Unknown & $\begin{array}{l}\text { Checkout Started }-1979 \\
15,000 \text { Kilowatts Output }\end{array}$ & $\begin{array}{l}\text { Use: Gas Turbine Combustion } \\
\text { Electrical Output } 15,000 \text { Kilowatts } \\
\text { Bleed Air From Compressor Feeds Gasifier } \\
\text { Desires Confidentiality }\end{array}$ \\
\hline $\begin{array}{l}\text { Howmet Corporation } \\
\text { Hazleton, Pennsylvania }\end{array}$ & LBG & $\begin{array}{l}\text { Wellman- } \\
\text { Galusha, } \\
\text { Agitator }\end{array}$ & 1 & 600 Million BTU/Day & Anthracite & $\begin{array}{l}\text { Metal } \\
\text { Processing } \\
\text { Furnace }\end{array}$ & Hot Raw Gas & Start-up Planned July 1979 & $\begin{array}{l}\text { Use: Heating and Melting Aluminum } \\
\text { Decision Driver-Fuel Security }\end{array}$ \\
\hline $\begin{array}{c}\text { Chemical Exchange } \\
\text { Houston, Texas }\end{array}$ & LBG & $\begin{array}{l}\text { Wellman- } \\
\text { Galusha. } \\
\text { Agitator }\end{array}$ & 1 & Unknown & Liqnite & Unknown & Unknown & Construction - 1979! & Desires Confidentiality \\
\hline \multicolumn{10}{|c|}{ PLANNED UNITS } \\
\hline $\begin{array}{l}\text { Carter Oil Company } \\
\text { Houston, Texas }\end{array}$ & MBG & Lurgi & Unk & $\begin{array}{l}300 \text { Billion BTU/Day } \\
\text { Total }\end{array}$ & Lignite & Distribution & Cold clean & $\begin{array}{l}\text { Construction Start } 1985 / 1986 \\
\text { Start-Up Estimated } 1987\end{array}$ & $\begin{array}{l}\text { Planning Started } 1974 \\
\text { Gas Not Available for Sale Until } 1990 \text { 's } \\
\text { Delayed Construction due to Funding Problem } \\
\text { Second Unit Planned } 198711988 \\
\text { Gas To Be Transported 150 Miles to } \\
\text { Gulf Coast Area }\end{array}$ \\
\hline $\begin{array}{l}\text { Illinois Power Company } \\
\text { Wood River, Illinois }\end{array}$ & LBG & \begin{tabular}{|l|} 
Allis- \\
Chalmers
\end{tabular} & 1 & 12.5 Billion BTU/Day & $\begin{array}{l}\text { Bituminous } \\
\text { High Sulfur }\end{array}$ & $\begin{array}{l}\text { Electric } \\
\text { Generation }\end{array}$ & Cold Clean & $\begin{array}{l}\text { Consortium with State, Allis } \\
\text { Chalmers, Illinois power } \\
\text { Company. Construction } \\
\text { Planning } 1981 \text { Initial } \\
\text { Testing Planning } 1982\end{array}$ & Use: Electric Generation, 60 Megawatts \\
\hline Southern California Edison & MBG & Texaco & 1 & 16.8 Billion BTU/Day & Unknown & $\begin{array}{l}\text { Electric } \\
\text { Generation }\end{array}$ & Cold clean & Start-up Planned 1980 & Use: Electric Generation, 50 Megawatts \\
\hline
\end{tabular}


Two chemical companies, Gulf \& Western corporation and Olin Chemical Company, both of Ashtabula, Ohio installed coke and oxygen fed gasifiers in 1963. These medium-Btu gasifiers are sources of carbon-monoxide for chemical processes. No MBG coal-fed plants are in operation in the United States. National Lime and Stone Company of Carey, Ohio, installed an LBG gasifier in 1955.

2. Industry Is Actively Investigating the Applicability of Coal Gasification to Processes. Five Privately Funded Projects Are Being started Up or Are in Construction

Privately funded commercial projects are being initiated by at least five companies in the United States. Four companies have released information concerning project schedules, and have announced construction completion to occur by the end of 1979, as shown previously in Exhibit IV-3.

3. Three Major Industrial Projects, Privately Funded, Are known to Be in serious Planning. Today

Carter Oil Company, a subsidiary of Exxon, began design work in 1974 for a multi-user MBG facility, using Texas lignite in eastern Texas. Construction is to begin in 1985-1986, and gas is expected to be available for sale in the early 1990's. The facility will be located near Houston, Texas and will ship MBG 150 miles to the Gulf coast area for feedstock and fuel to the chemical industry. Lurgi is the selected gasifier manufacturer, and the output is planned to be 300 billion Btu/day.

Two electric utilities, Illinois power and Southern California Edison, both plan coal gasification facilities for electric power generation. The Southern California Edison MBG plant construction is expected to begin in 1979 or 1980, and the Illinois Power LBG plant in 1981.

(2) Eight Gasification Projects Have Been Sponsored by the Federal Government. Two Projects Are Operating and One Is Being Checked Out

Exhibit IV-4 identifies the U.S. Government and government-industry projects, with details as to key 
dates, type of gasifier, and coal feedstock. Small, low-Btu gasifier test units are in operation by the U.S. Bureau of Mines and the Department of Energy.

1. The U.S. Government Sponsored An LBG coal Gasification Facility in 1940

The earliest present user of coal gasification is the U.S. Army's Holston Defense Corporation, Kingsport, Tennessee. In-1940, 12 Wilputte gasifiers were installed for munitions manufacturing when no natural gas was available.

2. The U.S. Department of Energy (ERDA) Initiated the Coal Conversion and Utilization Program, PON FE-4, ${ }^{*}$, to Increase Experience in Coal Gasification

The PON FE-4 program was designed to provide equal DOE and participant funding of the total cost of design, construction, and initial operation for demonstration projects using commercially available coal gasification equipment. The technical financial data from these projects became public information.

of the original six projects accepted for the PON FE-4, three projects are active. One project, Glen-Gery Corporation, is in operation. The University of Minnesota project is soon to become operational, and the pike county project will be operational next year. Three projects have been cancelled.

3. The U.S. Department of Commerce's Economic Development Administration Is Funding a Coal Gasification Project to stimulate Industry in a Depressed Area

Similar to...PON.'FE-4, equal funding is..being provided by the Department of Commerce and the " program participant, Can-Do Incorporated, for the installation of a low-Btu gasifier system. The project is to provide energy for the Humboldt

* PON FE-4, March 30, 1976, Energy Research and Deveiopment Administration, Division of Coal Conversion and Utilization. 
Industrial Park, Hazelton, Pennsylvania, using local anthracite coal for the fuel feedstock.

4. A Demonstration Plant Featuring a Chemically Activated Fluidized Bed Process for Producing Low Sulfur LBG From lignite Is Being Funded By the Environmental Protection Agency

The first demonstration plant to produce combustion gas from lignite and high sulfur oil, and feed it directly into a power station, has gone on line at the Central power and light utility in san Benito, Texas. The project is a joint venture involving Central \& Southwest Corporation, Foster Wheeler Energy Corporation and the Federal EPA. The gasifier was started in May 1979 with lignite, and was switched to high sulfur fuel oil for checkout. By about December 1979 the gasifier is expected to become operational using lignite only.

5. A Multiple-User MBG Facility Partially Funded By DOE May Begin Construction in 1980

A multiple customer medium-Btu project is being planned for the Memphis Light, Gas and Water Utility, Memphis, Tennessee. The Phase One, Planning, was completed in July 1979, and with DOE approval, the 50 percent cost-shared project will begin construction in 1980 .

6. A TVA-Funded Ammonia-From-Coal Demonstration Plant Is Now in Planning, with Construction Expected to Be Completed in 1980

The Tennessee Valley Authority has contracted for the construction of an ammonia-coal gasification plant at Muscle shoals, Alabama, to be completed in 1980. The facility will consume 168 tons/ day of coal, chiefly eastern low-sulfur and midwestern high-sulfur varieties, producing synthesis gas to yield 135 tons/day of ammonia at a retrofitted fertilizer plant.

(3) There Are substantial Numbers of Coal Gasifiers Operating Overseas

Coal gasification has an extensive operating history throughout the world. This foreign experience base encompasses a variety of economic, political, and 
EXHIBIT IV-4

tatus of U.S GovernmentSponsored Gasifier Projects

\begin{tabular}{|c|c|c|c|c|c|c|c|c|c|c|}
\hline \multirow[b]{3}{*}{ COMPANY/PROJECT } & \multirow{3}{*}{$\begin{array}{c}\text { GAS } \\
\text { TYPE }\end{array}$} & \multicolumn{9}{|c|}{ U.S. GOVERNMENT. SPONSORED PROJECTS } \\
\hline & & \multicolumn{6}{|c|}{ GASIFIER INFORMATION } & \multirow{2}{*}{ STATUS } & \multirow{2}{*}{$\mid \begin{array}{c}\text { GOVERNMENT } \\
\text { FUNDING } \\
\text { SOURCE }\end{array}$} & \multirow[b]{2}{*}{ - REMARKS } \\
\hline & & TYPE & U:ITS & $\begin{array}{l}\text { OUTPUT } \\
\text { EACH UNIT }\end{array}$ & $\begin{array}{l}\text { COAL } \\
\text { TYPE }\end{array}$ & $\begin{array}{l}\text { GAS } \\
\text { USE }\end{array}$ & $\begin{array}{c}\text { GAS } \\
\text { CLEAN-UP }\end{array}$ & & & \\
\hline $\begin{array}{l}\frac{\text { OPERATING UNITS }}{\text { Holston Defense corporation }} \\
\text { Kingsport, }\end{array}$ & LBG & \begin{tabular}{|l} 
Wilputte, \\
Agitator
\end{tabular} & 12 & 375 Million BTU/Day & \begin{tabular}{|l} 
Bituminous, \\
Low Sulfur, \\
High vola- \\
tilies
\end{tabular} & $\begin{array}{l}\text { Chemical } \\
\text { Furnace }\end{array}$ & Detarred & Installation $\left.\right|_{1940} ^{-1940}$ & DOD & $\begin{array}{l}\text { Use: Manufacture of Munitions, } \\
\text { Acidic Anhydride when Installed. } \\
\text { No Natural Gas Avaliable T Tho } \\
\text { Gasifiers Used on Rotating Basis } \\
\end{array}$ \\
\hline $\begin{array}{l}\text { Glen Gery Corporation } \\
\text { York, Pennsylvania }\end{array}$ & LBG & \begin{tabular}{|l} 
Wellman- \\
Galusha
\end{tabular} & & |576 Million BTU/Day & Anthracite & $\begin{array}{l}\text { Brick } \\
\text { Kiln }\end{array}$ & Hot Raw Gas & Startup october 1977 & $\begin{array}{l}\text { DOE } \\
\text { PONEE-4 }\end{array}$ & $\begin{array}{l}\text { System is operating satisfactorily } \\
\text { Good instrumentation }\end{array}$ \\
\hline $\begin{array}{c}\text { CONSTRUCTION/CHECKOUT UNITS } \\
\text { University of Minnesota } \\
\text { Duiuth, Minnesota }\end{array}$ & LBG & $\begin{array}{l}2 \text { Stage } \\
\text { stoic }\end{array}$ & 1 & $\mid 1.44$ Billion BTU/Day $\mid$ & Variety & $\begin{array}{l}\text { Space Heating } \\
\text { Furnace }\end{array}$ & Detarred & $\begin{array}{c}\text { Checkout started } 1979 \\
\end{array}$ & $\begin{array}{l}\text { DOE } \\
\text { PONFE-4 }\end{array}$ & $\begin{array}{l}\text { Operating satisfactorily } \\
\text { using non-decrepitating western } \\
\text { sub-bituminous coal }\end{array}$ \\
\hline $\begin{array}{l}\text { Central Power \& Light } \\
\text { San Benito, Texas }\end{array}$ & $\begin{array}{l}\mathrm{LBG} \\
(250 \mathrm{BTU} / \mathrm{CF})\end{array}$ & \begin{tabular}{|l}
$\begin{array}{c}\text { Foster } \\
\text { wheeler }\end{array}$ \\
W l
\end{tabular} & 1 & $\mid 660$ Million BTU/Day & Lignite & \begin{tabular}{|l} 
Steam Boiler \\
Generating Electricity
\end{tabular} & Hot Clean & $\begin{array}{l}\text { Startup May } 1979 \text { on } \\
\text { Lignite, switched to oil } \\
\text { for checkout }\end{array}$ & EPA & $\begin{array}{l}\text { Demonstration of chemically } \\
\text { active fluidized bed gasifier } \\
\text { (ESSO, England). Lignite tests } \\
\text { to start about December } 1979 \\
\end{array}$ \\
\hline $\begin{array}{l}\frac{\text { PLANNED UNITS }}{\text { Pike County Coal }} \\
\text { Gasification Project } \\
\text { Pikeville, Kentucky }\end{array}$ & LBG & $\begin{array}{l}\text { Wellman } \\
\text { Galushat, } \\
\text { Agitator }\end{array}$ & 2 & $\begin{array}{l}\text { 1.4 Billion BTU/Day } \\
\text { Low Sulfur }\end{array}$ & Bituminous & $\frac{1}{\text { Steam Furnace }}$ & Hot Raw Gas & $\begin{array}{c}\text { Startup planned } \\
\text { April } 1980\end{array}$ & $\begin{array}{l}\text { DOE } \\
\text { PONFE-4 }\end{array}$ & $\begin{array}{l}\text { Use: Generate steam to heat and } \\
\text { cool (absorbtion) comnunity de- } \\
\text { velopment project, including } \\
\text { apartment complex, shopping cen- } \\
\text { ter, school, and nursing school. } \\
\text { To promote kentucky coal use }\end{array}$ \\
\hline $\begin{array}{l}\text { Can-Do, Inc. } \\
\text { Humboldt Industrial park } \\
\text { Hazelton, Pensylvania }\end{array}$ & LBG & $\begin{array}{l}\text { Wellman- } \\
\text { Galushia }\end{array}$ & 2 & 576 Million BTU/Day & Anthracite & $\begin{array}{l}\text { Space Heating } \\
\text { Furnace }\end{array}$ & Cold Clean & $\underset{\text { Startup planned }}{\text { July } 1980}$ & DOC & $\begin{array}{l}\text { Decision driver: promote area } \\
\text { industry. End use: generate } \\
\text { steam to heat Humbolt Industrial } \\
\text { park. }\end{array}$ \\
\hline $\begin{array}{l}\text { TVA } \\
\text { Muscle Shoals, Alabama }\end{array}$ & $\begin{array}{l}\text { MBG } \\
\text { Feedstock }\end{array}$ & Tcxaco & 1 & $\begin{array}{l}10 \text { Million SCF/Day } \\
\text { of } \mathrm{H}+\mathrm{CO}\end{array}$ & Bicuminous & $\begin{array}{l}\text { Chemical Feedstock } \\
\text { Ammonia }\end{array}$ & cold Clean & Startup planned 1980 & IVA & $\begin{array}{l}\text { 3-year demonstration project } \\
130 \text { ton/day ammonia }\end{array}$ \\
\hline $\begin{array}{l}\text { Memphis Light, Gas \& Water } \\
\text { Memphis Tennesee }\end{array}$ & $\begin{array}{ll}\mathrm{MBG} & \\
(284 \mathrm{BTU} / \mathrm{SCF})\end{array}$ & \begin{tabular}{|l} 
Foster \\
wheeler
\end{tabular} & 1 & 50 Billion BTU/Day & Bituminous & $\begin{array}{c}\text { Multiple Customex } \\
\text { Distribution }\end{array}$ & Hot Clean & $\begin{array}{l}\text { Planning phase one com- } \\
\text { plete. July } 1979 \text { con- } \\
\text { struction planned } 1980\end{array}$ & DOE & IGT U-Gas process \\
\hline w. R. Grace & $\begin{array}{l}\vdots \\
\text { MBG } \\
\text { Feedstock }\end{array}$ & Texaco & $\begin{array}{l}1 \\
\text { With } \\
\text { Spare }\end{array}$ & $\begin{array}{l}1200 \text { Tons/Day } \\
\text { Coal Feedd }\end{array}$ & $\begin{array}{l}\text { Kentucky } \\
\text { No. } 9\end{array}$ & $\begin{array}{c}\text { Ammonia } \\
\text { Prnduction } \\
\vdots\end{array}$ & Cold Clean & $\begin{array}{c}\vdots \\
\text { Completing Detailed } \\
\text { Design }\end{array}$ & DOE & \\
\hline
\end{tabular}


institutional factors, which differ from:those in the U.S. Most of the present U.S. users and those planning construction through the DOE PON FE-4 Program have visited installations in Europe and South Africa, discussing applications and retrofit problems. Several U.S. potential users of coal gasification have shipped coal samples to Westfield, Scotland"and Sasolburg, S.A. for compatibility tests.

Exhibit IV-5 contains a list of foreign coal gasification installations in operation, with information recently supplied by Lurgi, McDowell-Wellman, Koppers Engineering and, Construction, and Woodal1-Duckham Company.

3. PRESENT U.S. INDUSTRIAL USERS OF LOW- AND MEDIUM-BTU GASIFIERS ARE MOTIVATED BY SEVERAL FACTORS

Key managers of $13 \mathrm{U} . \mathrm{S}$. companies involved with coal gasification projects were interviewed for this study.

(1) Fuel security and the Resulting Overall Effect on Business Costs Is the Primary Motivation for a U.S. Company to Use the Coal Gasification Process

In most cases managers of U.S. firms which decided to use coal gasification were motivated by a history of natural gas interruptions. The following responses were received as to the reason why the company was using coal gasification:

Principal Motivation

Number of Users Responding

Fuel security

Economics

Encourage use of local coal

Require $\mathrm{CO}$

No natural gas available

2

Of the companies concerned with fuel security, four had natural gas curtailment of 2 years or more, and three had 3 years of curtailments. The remainder reported long periods of curtailment with no indication as to the number of years. Importantly, most company decisionmakers are not focusing on the uncertainty of supply more than 2 to 3 years ahead. 
ÉXHIBIT IV-5

Foreign Coal Gasifiers in operation

Spring 1979

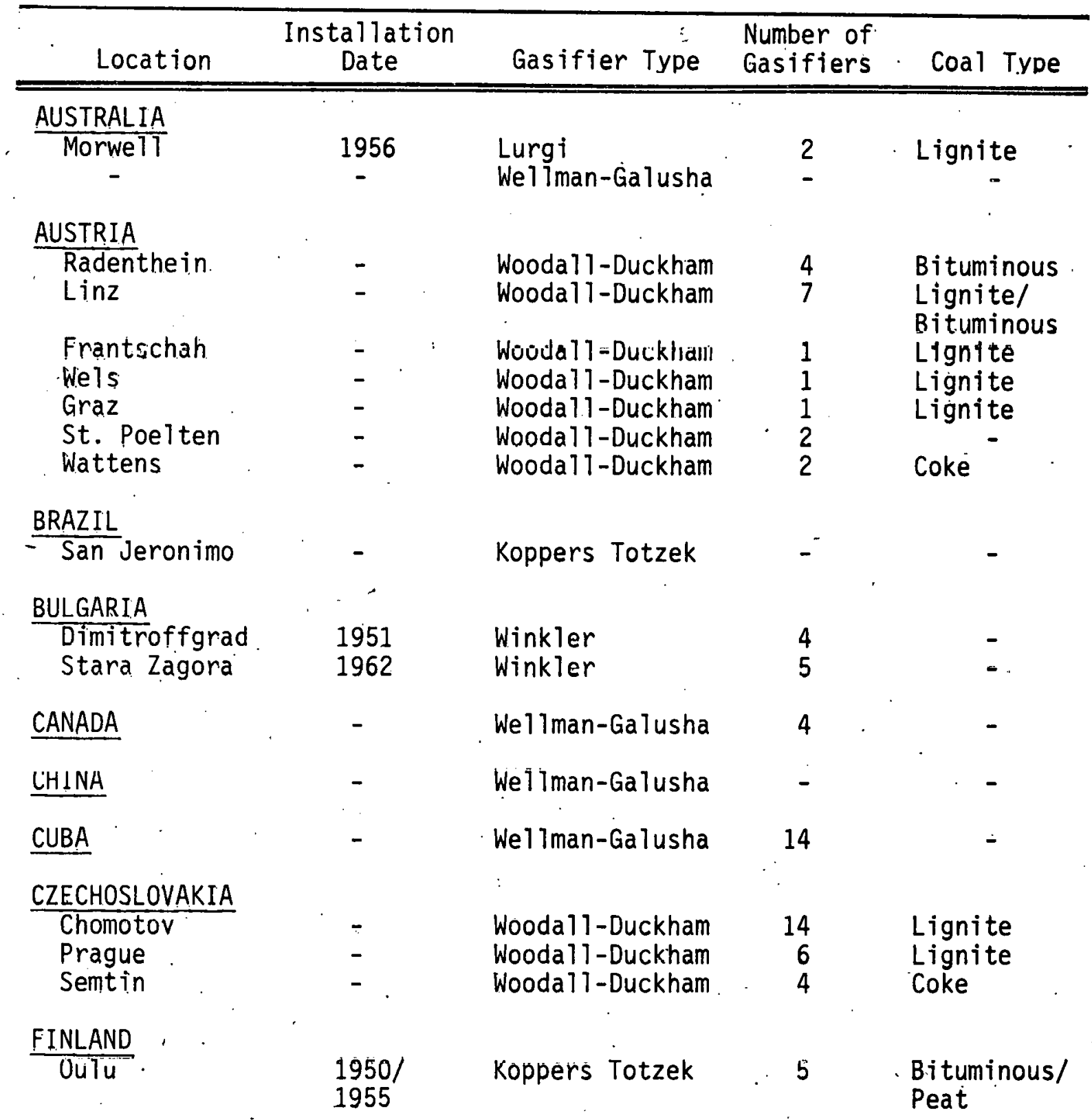


EXHIBIT IV-5

(Continued).

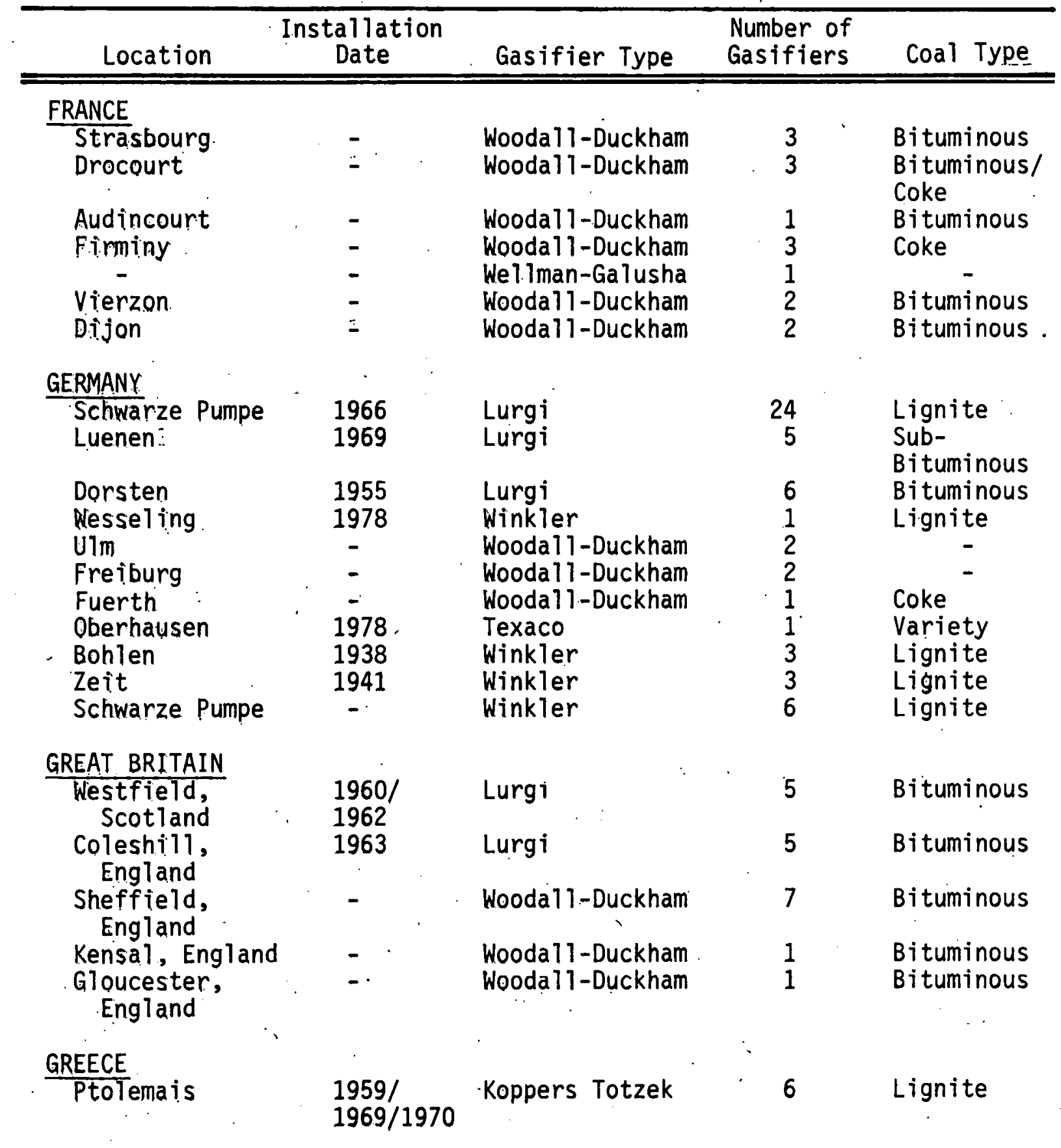


EXHIBIT IV-5

(Continued)

\begin{tabular}{|c|c|c|c|c|}
\hline Location & $\begin{array}{c}\text { Installation } \\
\text { Date }\end{array}$ & Gasifier Type & $\begin{array}{l}\text { Number of } \\
\text { Gas ifijers }\end{array}$ & Coal Type \\
\hline INDIA & & & & \\
\hline \multirow{2}{*}{$\begin{array}{l}\text { Orissa } \\
\text { Ramagundam }\end{array}$} & \multirow{2}{*}{$\begin{array}{c}\text { Construction } \\
1969 / \\
1979\end{array}$} & Koppers Totzek & - & - \\
\hline & & Koppers Totzek & $4+$ & - \\
\hline Kurba & $\begin{array}{l}1971 / \\
1979\end{array}$ & Koppers Totzek & $4+$ & - \\
\hline Talcher & 1970 & Koppers Totzek & 4 & - \\
\hline \multirow{3}{*}{$\begin{array}{l}\text { - } \\
\text { Madias } \\
\text { Jealbora }\end{array}$} & - & Wellman-Galusha & 6 & - \\
\hline & \multirow{2}{*}{$\begin{array}{l}1961 \\
1961\end{array}$} & Winkler & 3 & Lignite \\
\hline & & Lurgi & 1 & Various \\
\hline \multicolumn{2}{|l|}{ ITALY } & & $\cdot$ & \\
\hline Naples & - & Woodal1-Duckham & 4 & Bituminous \\
\hline Rome & - & Woodal1-Duckham & 5 & - \\
\hline Trieste & - & Wooda 11 -Duckham & 2 & - \\
\hline Milian & \multirow{2}{*}{ - } & Woodal1-Duckham & 3 & Coke. \\
\hline La Spezia & & Wooda 11-Duckham & 1 & - \\
\hline Como & - & Woodal 1-Duckham & 1 & - \\
\hline Genda & - & Wooda 11 -Duckham & 4 & - \\
\hline Crotone & - & Wooda 11-Duckham & 2 & - \\
\hline Porto Marghera & - & Wooda 11 -Duckham & 2 & Bituminous \\
\hline $\begin{array}{c}\text { St. Giuseppe } \\
\text { Di Cairo }\end{array}$ & . & Woodal1-Duckham & 2 & - \\
\hline \multicolumn{5}{|l|}{ JAPAN } \\
\hline Tokyo & - & Wooda11-Duckham & 5 & - \\
\hline PAKISTAN & - & Wellman-Galusha & - & - \\
\hline$\underline{\text { PERU }}$ & - & Wellman-Galusha & - & - \\
\hline PHILIPPINES & - & Wellman-Galusha & - & - \\
\hline POI.AND & & , & & \\
\hline Warsaw & - & Woodal1-Duckham & 3 & - \\
\hline Thom & - & Wooda 11-Duckham & 2 & - \\
\hline Posen & - & Woodal1-Duckham & 3 & - \\
\hline PORTUGAL & & & & \\
\hline Lisbon & 1956 & Koppers Totzek & - & Anthracite \\
\hline
\end{tabular}


EXHIBIT IV-5

(Continued)

\begin{tabular}{|c|c|c|c|c|}
\hline Location & $\begin{array}{c}\text { Installation } \\
\text { Date }\end{array}$ & Gasifier Type & $\begin{array}{l}\text { Number of } \\
\text { Gasifiers }\end{array}$ & Coal Type \\
\hline \multicolumn{5}{|l|}{ SOUTH AFRICA } \\
\hline Sasolburg & $\begin{array}{r}1954 \\
.1958\end{array}$ & $\begin{array}{l}\text { Lurgi } \\
\text { Lurgi }\end{array}$ & $\begin{array}{r}10 \\
1\end{array}$ & $\begin{array}{l}\text { Bituminous } \\
\text { Sub- } \\
\text { Bituminous }\end{array}$ \\
\hline & $\begin{array}{l}1966 \\
1973\end{array}$ & $\begin{array}{l}\text { Lurgi } \\
\text { Lurgi }\end{array}$ & $\begin{array}{r}3 \\
4\end{array}$ & $\begin{array}{l}\text { Bituminous } \\
\text { Bituminous }\end{array}$ \\
\hline $\begin{array}{l}\text { Sasol } 11 \\
\text { (Secunda) }\end{array}$ & 1974 & Lurgi & 36 & Bituminous \\
\hline- & - & Wellman-Galusha & 1 & "Bituminous \\
\hline $\begin{array}{l}\text { Driefontein } \\
\text { Lydenberg }\end{array}$ & $\begin{array}{l}1972 \\
1976\end{array}$ & $\begin{array}{l}\text { Stoic } \\
\text { Stoic }\end{array}$ & $\begin{array}{l}1 \\
1\end{array}$ & $\begin{array}{l}\text { Bituminous } \\
\text { Bituminous }\end{array}$ \\
\hline Modderfonte in & - & Koppers Totzek & 6 & Bituminous \\
\hline Grootfontein & 1970 & $\begin{array}{l}\text { Weilman } \\
\text { Incandescent }\end{array}$ & 1 & Bituminous \\
\hline Scaw Metals & $\begin{array}{l}1963 / 1968 / \\
1970 / 1975\end{array}$ & $\begin{array}{l}\text { Wellman } \\
\text { Incandescent }\end{array}$ & 5 & Bituminous \\
\hline $\begin{array}{l}\text { Cullinan } \\
\text { Refrac. }\end{array}$ & $\begin{array}{l}1964 / \\
1965 / 1973\end{array}$ & $\begin{array}{l}\text { We } 11 \text { man } \\
\text { Incandescent }\end{array}$ & 4 & Bituminous \\
\hline Saiccor & 1973 & $\begin{array}{l}\text { We } 17 \text { man } \\
\text { Incandescent }\end{array}$ & 1 & Bituminous \\
\hline Johannesburg & 1975 & $\begin{array}{l}\text { We } 17 \text { man } \\
\text { Incandescent }\end{array}$ & 1 & Bituminous \\
\hline Southern Steel & $\begin{array}{l}1966 / \\
1976\end{array}$ & $\begin{array}{l}\text { Wel lman } \\
\text { Incandescent }\end{array}$ & 2 & Bituminous \\
\hline Highveld Steel & $\begin{array}{l}1968 / \\
1976\end{array}$ & $\begin{array}{l}\text { We } 1 \text { Iman } \\
\text { Incandescent }\end{array}$ & 5 & Bituminous \\
\hline $\begin{array}{l}\text { Stewarts } \\
\quad \& \text { Lloyds }\end{array}$ & 1964 & $\begin{array}{l}\text { We IIman } \\
\text { Incandescent }\end{array}$ & 1 & Bituminous \\
\hline Johannesberg & $\begin{array}{l}1965 / \\
1968\end{array}$ & $\begin{array}{l}\text { We } 1 \text { Iman } \\
\text { Incandescent }\end{array}$ & 5 & Bituminous \\
\hline $\begin{array}{l}\text { Consolidated } \\
\text { G.lass }\end{array}$ & 1967 & $\begin{array}{l}\text { We } 1 \text { lman } \\
\text { Incandescent }\end{array}$ & 2 & Bituminous \\
\hline Springs & - & Wooda 11 -Duckham & 2 & Bituminous \\
\hline Meyerton & - & Woodal1-Duckham & 1 & Bituminous \\
\hline Johannesburg & - & Wooda 11-Duckham & 2 & Bituminous \\
\hline $\begin{array}{l}\text { Stewarts } \\
\quad \& \text { Lloyds }\end{array}$ & - & Woodal1-Duckham & 3 & Bituminous \\
\hline $\begin{array}{l}\text { Escault } \\
\text { Mandini }\end{array}$ & $\begin{array}{l}- \\
-\end{array}$ & $\begin{array}{l}\text { Wooda } 11 \text {-Duckham } \\
\text { Wooda } 7.7 \text {-Duckham }\end{array}$ & $\begin{array}{l}3 \\
2\end{array}$ & $\begin{array}{l}\text { Bituminous } \\
\text { Bituminous }\end{array}$ \\
\hline Vereenigning & - & Woodal1-Duckham & 1. & Bituminous \\
\hline Driefontein & - & Wooda11-Duckham & 2 & Bituminous \\
\hline Vereeniging & - & Wooda 11-Duckham & 2 & Bituminous \\
\hline
\end{tabular}


EXHIBIT IV-5

(Continued)

\begin{tabular}{|c|c|c|c|c|}
\hline Location & $\begin{array}{c}\text { Installation } \\
\text { Date }\end{array}$ & Gasifier Type & $\begin{array}{l}\text { Number of } \\
\text { Gasifiers }\end{array}$ & Coal Type \\
\hline$\frac{\text { SOUTH AFRICA }}{\text { (Continued). }}$ & & & & \\
\hline $\begin{array}{l}\text { Pretorea } \\
\text { Dundee } \\
\text { Alusaf }\end{array}$ & $\begin{array}{l}1933 / 1934 \\
1949 \\
1978\end{array}$ & $\begin{array}{l}\text { Riley-Morgan } \\
\text { Riley-Morgan } \\
\text { Wellman } \\
\text { Incandescent }\end{array}$ & $\begin{array}{l}7 \\
2 \\
2\end{array}$ & $\begin{array}{l}\text { Bituminous } \\
\text { Bituminous } \\
\text { Bituminous }\end{array}$ \\
\hline & 1975 & $\begin{array}{l}\text { Wellman } \\
\text { Inc.andescent }\end{array}$ & 1 & Bituminous \\
\hline USCO & 197,3 & $\begin{array}{l}\text { Wellman } \\
\text { Incandescent }\end{array}$ & 1 & Bituminous \\
\hline SPAIN & & & & \\
\hline La Coruma, & \&1954/1961 & Koppers Totzek & 4 & Lignite \\
\hline TAIWAN & - & Wellman-Gälusha & 6 & - \\
\hline$\frac{\text { THAILAND }}{\text { Lampang }}$ & 1963 & Koppers Totzek & 1 & Lignite \\
\hline $\begin{array}{l}\frac{\text { TURKEY }}{\text { Ankara }} \\
\text { Istanbul }\end{array}$ & 1966 & $\begin{array}{l}\text { Koppers Totzek } \\
\text { Woodal1-Duckham }\end{array}$ & $\begin{array}{l}4 \\
1\end{array}$ & $\begin{array}{l}\text { Lignite } \\
\text { Lignite }\end{array}$ \\
\hline $\begin{array}{l}\frac{\text { USSR }}{\text { SaTawad }} \\
\text { Baschkirien }\end{array}$ & - & $\begin{array}{l}\text { Winkler } \\
\text { Winkler }\end{array}$ & $\begin{array}{l}7 \\
4\end{array}$ & $\begin{array}{l}- \\
-\end{array}$ \\
\hline YUGOSLAVIA & & & & \\
\hline $\begin{array}{l}\text { Jendinjenja, } \\
\text { Gorazde }\end{array}$ & $\overline{1952}$ & $\begin{array}{l}\text { Wellman-Galusha } \\
\text { Winkler }\end{array}$ & $\begin{array}{l}1 \\
1\end{array}$ & - \\
\hline$\frac{\text { ZAMBIA }}{\text { Kafue }}$ & $\begin{array}{l}1967 / \\
1974 / 19.75\end{array}$ & Koppers Totzek & 3 & Bituminous \\
\hline
\end{tabular}


(2) The Operating Commercial Users, and Most of the Government and New Commercial Projects of Low-

Btu Gas, Consider the Manufactured Gas to Be Economically Attractive when Compared to Natural Gas Costs

All of the current operating commercial gasifier users have equipment that is fully depreciated. Only their variable costs of coal; labor and periodic maintenance are considered in the determination of the cost of the coal gas. Of the new privately funded and the government cost-shared projects, over half determine their coal gas costs to be the variable costs, plus. capital depreciation and cost of money, with no requirement for a rate-of-return on investment (ROI). The new projects are considered as research and development by management and exempt from ROI hurdles. In most cases, any future programs would have to meet the normal economic and financial criteria, with most companies expecting an after-tax ROI of about 15 percent.

One company receiving cost-sharing funds from PON FE-4 used more typicai business accounting. They required, for a go-ahead decision, a favorable coal gas cost-projection when compared to natural gas and oil costs over a 5-year average, when considering the following cost assumptions:

- Natural gas a $\$ 2.60 / \mathrm{million}$ Btu

- \#6 oil a 39k/gallon, plus $6 \% / g a l l o n$ freight

- Coal a $\$ 5 /$ ton (lignite waste) plus $\$ 10.50 /$ ton freight

First-year costs must include start-up charges

- Natural gas and coal price escalation of 10 percent/year including inflation

10 percent investment tax credit

10 percent additional tax credit for energy conversion equipment

14-year SL capital depreciation

20 percent ROI before taxes

Labor of one man/shift. 
(3) Coal Type and Transportation Requirements Are Responsible for a large part of the Current Users Coal Gas Costs

Coal costs for the present LBG users varied from $\$ 15.49 /$ ton delivered for lignite fines used in one project to $\$ 55 /$ ton of bituminous coal site delivered. Transportation in the first case constituted two-thirds of the cost, and in the latter about one-half of the costs. The average price of coal paid by the projects responding was $\$ 37.25 \%$ ton site delivered.. The cost per milition Btu of coal feedstock varied from $\$ 0.95$ low to $\$ 2.30 \mathrm{high}$. The average cost of the coal feedstock was $\$ 1.60 / \mathrm{million}$ Btu.

\section{Labor Cost Requirements Vary Considerably,} Deperialng Upon uninn Reruirements

1 There are no extraordinary skills required to operate a coal gasifier above those normally required for power plant operation. Labor required for a coal gas facility depends upon the size of the unit. Small anthracite-fed, Wellman-Galusha gasifiers are reported to require no more than 1/4-man/shift per gasifier for coal and ash handling. Units with 500 percent greater output under union contracts are reported to require $1 \frac{1}{2}-\operatorname{man} / \mathrm{shift}$.

Labor requirements were reported by eight current users and projected users. These are as follows:

Manpower/Unit/Shift Number, of Ũiseirs $1 / 4$
$1 / 2$
1
$1-1 / 2$
2 Responding

1
2
3
1
1

The two facilities reporting the larger manpower roquirements are union bliupe. One roported that lie factory had a union requirement but that during the initial startup and operation period of about 3 months, the coal gasifier would be exempt from compliance. Thereafter, the manpower would be supplied by the union. 
(5) While There Is Substantial Disagreement Among Managements As to How the cost of Coal Gas Is to Be Determined, There Is General Agreement That the Costs Are Comparable with Natural Gas Prices

Low-Btu coal gas costs reported or estimated from information supplied from nine projects are shown in Exhibit IV-6. Excluding the high of $\$ 3.10^{\prime}$ and the low of $\$ 2.05$, the average coal gas cost is $\$ 2.40$ per mil- Iion Btu of low-Btu gas. Most companies reporting actual costs use older, depreciated equipment with no requirement for a return-on-investment. The newer projects are inconsistent in accounting requirements.

The LBG gas costs as perceived by most companies are comparable with natural gas. In the areas of the coal gasification projects natural gas prices vary between. $\$ 2$ and $\$ 3$ per million Btu.

4. MOST OF THE PRESENT USERS AND PROJECTED USERS DID NOT HAVE COAL BURNING EXPERIENCE

Coal handling and burning experience was not prevalent among the users of coal gasifiers. Of 13 participants, 10 companies reported no prior coal experience.

5. THE CURRENT TECHNOLOGY COAL GASIFIERS ARE REPORTED TO BE RELIABALE

No negative comments were received as to the reliability of the coal gasifier equipment. Three companies declared that the gasifier equipment. was more reliable than the factory production equipment. Of the operating users, all had critical spare parts on hand. One projected user planned on about $\$ 10,000$ spare inventory. Most present users performed their own repairs, making many parts locally. Critical parts could be ordered from the gasifier manufacturer.

6. CONCERN FOR ENVIRONMENTAL FACTORS VARIES WIDELY AMONG CURRENT USERS

There is conflicting concern among users as to whether environmental regulations inhibit the commercialization of coal gasification. Recent conversion plans, particularly those operating under PON FE-4, are being inhibited, according to the potential users, by the company's belief that EPA is interpreting the Clean Air Act Amendments of 1977 to require compliance of the entire plant. 
EXHIBIT IV-6

Reported Opérating Costs of LBG Gas

\begin{tabular}{|c|c|c|c|c|c|c|c|c|}
\hline & \multicolumn{5}{|c|}{ Cost/Million BTU } & \multicolumn{3}{|l|}{ Remarks } \\
\hline Company $A$ & & & $\$ 2.30$ & & & Actual & & \\
\hline Compàny $B$ & & , & $\$ 2.15$ & & . & Actual & $\therefore$ & \\
\hline Company $\mathrm{C}$ & & & $\$ 2.05$ & & & Actual & & \\
\hline Company U & & ' & $\$ 2.40$ & & & Actual & & \\
\hline Company $E$ & 1 & & $\$ 2.35$ & ' & & Est. Inc. & Sulfur & Cleanup \\
\hline Company $\Gamma$ & & & $\$ 2.65$ & & & Es tiiilà led & & \\
\hline Company $\mathrm{G}$ & & & $\$ 2.40$ & & & Estimated & & \\
\hline Company $\mathrm{H}$ & & & $\$ 2.50$ & 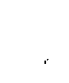 & & Estimated & & . \\
\hline Company I & & & $\$ 3.10$ & & & Est. Inc. & sulfur & cleanup \\
\hline
\end{tabular}

Source: Industry Interviews 
Because active removal of sulfur or tar and oil greatly increases costs, where possible most gas manufacturers are providing only particulate removal of the output gas. Many users use feedstock, such as coke or anthracite:coals, which preclude the necessity of gas clean-up. Other technologies, such as the wilputte process, crack the tars/oil in the reactor, thus precluding the necessity of active tar removal. The variety of comments made in discussions with present gasifier users is indicative of the wide range of views on environmental questions:

Company A: "No problem complying with EPA."
Company B: "No significant problem."
Company C: "Environment problems are severe. EPA
believes Clean Air Act of 1977 for coal-fired inbelieves Clean Air Act of 1977 for coal-fired in-
stallation must apply to coal gasification. Furthermore, State Departinent of Environmental Regulation (DER) took a strict interpretation of EPA implications."

- Company D: "EPA and the Pennsylvania Department of-Environmental Regulations stated that no emission requirements apply to gasifiers and there are no requirements to limit sulfur in heat-treat furnace stack gas. The company limited emissions for corporate image."

- Company E: "Potential carcinogen problem may' need to be explored although company is unaware as to actual problem."

7. THE PRESENT USERS PERCEIVE THE NEAR-TERM MARKET FOR LBG AND MBG GASIFIERS TO BE ENERGY-INTENSIVE INDUSTRIES LOCATED NEAR COAL RESOURCES

The following observations as to near-term markets for coal gasification were made by present and planned users of coal gasification.

(1) Current Users Expect a Market to Evolve for LBG and Multiple-User MBG Plants

Present LBG users expect early adopters to be those companies with a low fuel cost contribution to product final cost. These are the companies that can pay a cost premium for alternate fuels now with the expectation of nonavailability or high price of natural gas or oil in the future. 
Secondly, present users perceive that the early adopters are those customers with facilities having access to coals not requiring expensive clean-up. Typical would be companies with access to western lignite and Pennsylvania anthracite coals. Present users of coal gasification perceive that initial customers will be among the following industries:

- Initial MBG facilities will exist in metal processing industries using nitrogen with oxygen as a by-product.

- Initial LBG customers will require low to moderate temperatures found in process drying.

- IBG will be initially attractive in heatintensive industries such as metals, ceramics and textiles (singeing).

The glass industry will be a prime initial candidate for LBG, but due to possible contamination, retrofit may be costly.

Present users expect that early introduction of LBG may be through lease arrangements and through A./E firms providing turnkey services. Many have been approached by a process gas company and a gas utility to provide an LBG facility on the user property through a leasing agreement. They believe that when the market matures the users will buy the equipment and install it themselves.

Many present users expressed the view that multiuser facilities are not expected due to difficulties in obtaining agreements among companies, and due to potential conflicts with rate and safety regulations.

Current Users Expect the Market to Evolve in Texas, the Ohio River Valley and Near Western Coal Fields

Current users perceive that initial LBG and MBG customers will be in industries located near lignite deposits, i.e., Texas and North Dakota, or near anthracite deposits in Pennsylvania. In general, to capitalize on cheap coal (lignite) or coal not requiring extensive clean-up (anthracite), industries must be located within 200 miles of the preferred coal stocks.

Observations by current users on the regional character of near-term markets are summarized as follows: 


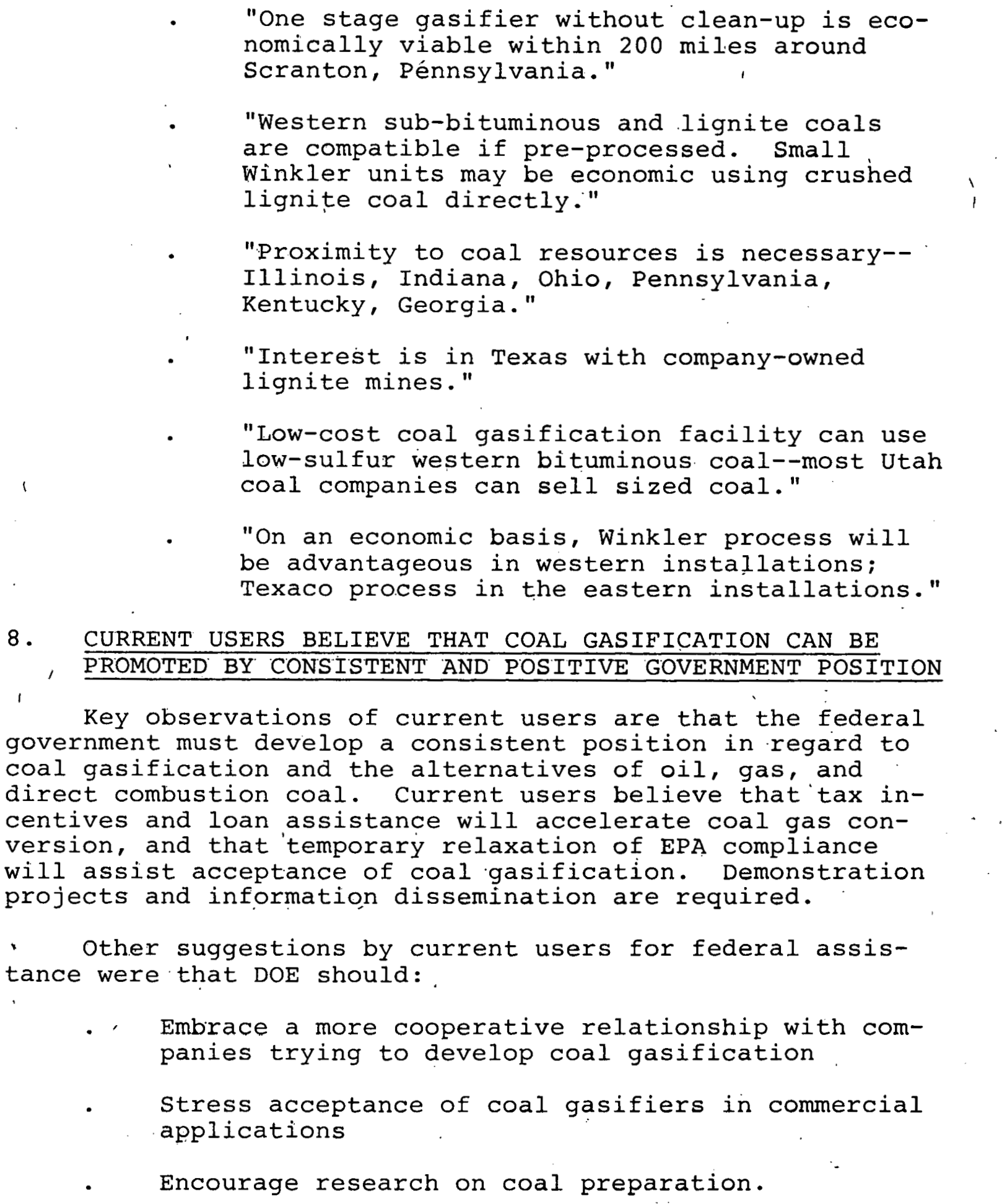

nomically viable within 200 miles around

"Western sub-bituminous and lignite coals are compatible if pre-processed. Small Winklex units may be economic using crushed lignite coal directly."

"Proximity to coal resources is necessary-Illinois, Indiana, Ohio, Pennsylvania, Kentucky, Georgia."

"Interest is in Texas with company-owned lignite mines."

"Low-cost coal gasification facility can use low-sulfur western bituminous coal--most Utah

"On an economic basis, Winkler process will be advantageous in western installations; Texaco process in the eastern installations."

\section{CURRENT USERS BELIEVE THAT COAL GASIFICATION CAN BE} PROMOTED BY CONSISTENT AND POSITIVE GOVERNMENT POSITION

Key observations of current users are that the federal government must develop a consistent position in regard to coal gasification and the alternatives of oil, gas, and direct combustion coal. Current users believe that tax incentives and loan assistance will accelerate coal gas conversion, and that temporary relaxation of EPA compliance will assist acceptance of coal gasification. Demonstration - projects and information dissemination are required.

Other suggestions by current users for federal assistance were that DOE should:

Embrace a more cooperative relationship with companies trying to develop coal gasification

Stress acceptance of coal gasifiers in commercial applications

Encourage research on coal preparation. 
The wide range of views by current users on what the federal government should do with regard to coal gasification is indicative of the emerging character of the technology and its use.

*

This chapter has presented a summary of the current and planned projects (U.S. and foreign), motivations for present gasifier investments and user observations of the near-term market. The next chapter presents the analysis of the technically feasible near-term market. 
V. ANALYSIS OF THE-TECHNICALLY-FEASIBLE MARKET FOR LOW- AND MEDIUM-BTU GASIFICATION 


\section{ANALYSIS OF THE TECHNICALLY-FEASIBLE MARKET FOR LOW- AND MEDIUM-BTU GASIFICATION}

Analysis of the 1985 industrial market for LBG and MBG is conducted in three parts. The first portion of the analysis, presented in this chapter, assesses the maximum potential market for $L B G$ and $M B G$ in industry. The second part, described in Chapter VI, pinpoints the regions in which the early adopters of coal gasification are most likely to be found. The third part, presented in Chapter VII, identifies the industries and regions actually expected to have adopted LBG or MBG by 1985 .

This chapter presents the analysis of the potential market, which has been defined for purposes of the study to be the maximum "technically feasible" maxket, based on the technical fit of the gas with industrial processes and on the characteristics of end-use plant energy demands.

The analysis focuses on a practical question: How large could the industrial market be for LBG and MBG, if the eonomics are attractive? Analysis and discussion conclude that this "technically feasible" market potential is at least:

$$
\begin{aligned}
& 3500 \text { LBG single-user plants } \\
& \text { - } \quad 550 \text { MBG single-user plants } \\
& \text { - } 300 \text { MBG multiple-user plants. }
\end{aligned}
$$

The gross energy value for the total estimated gasifier potential is as high as 3 Quads, as shown in Exhibit V-I.

The discussion is presented in five parts:

\footnotetext{
- Expected equipment configurations

- Discussion of evaluation criteria

- Feasibility by application

- Feasibility by industry

- Summary conclusions.
} 
EXHIBIT V-1

Maximum Feasible Market

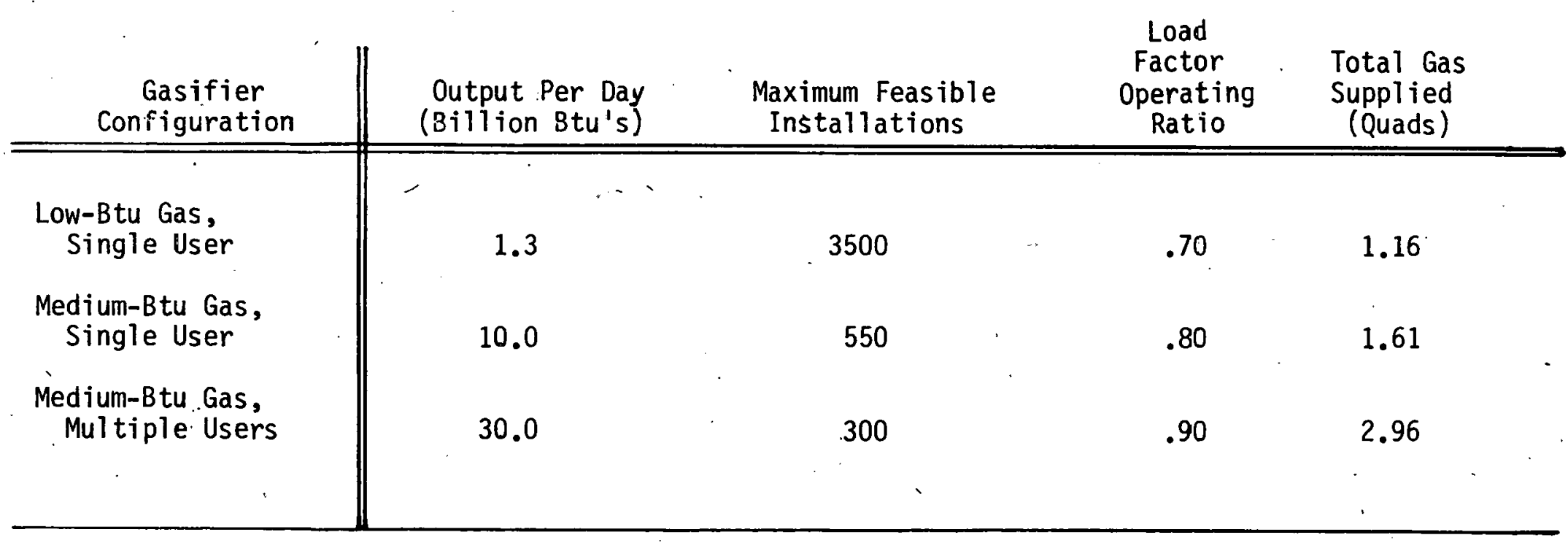


1. THERE ARE THREE PRINCIPAL MODES FOR INDUSTRIAL GASIFICATION : LOW-BTU SINGLE-USER, MEDIUM-BTU SINGLE-USER, AND MEDIUM-BTU MULTIPLE-USER PLANTS

The industrial marketplace views gasification technology as shown in Exhibit V-2:

Low-Btu (LBG) gasifier plants are typically comprised of several gasifier units (for added reliability), with or without gas clean-up trains, for dedicated use on a single industrial plant.

- LBG cannot be injected into the natural gas pipeline system for safety (hydrogen and carbon monoxide content), regulatory, operating and other reasons

- LBG plants will be situated physically in the industrial facility. Pipeline distribution is economically unattractive due to the low energy density of the gas (120-180 Btu/scf)

- Medium-Btu (MBG) gasifier plants can be dedicated to a single industrial user. Total configuration includes gasifier unit(s), oxygen plant, gas clean-up train and coal handling/storage equipment on site.

- The high capital costs and substantial economies of scale for the oxygen feed plant limit single-user MBG to large industrial facilities. (However, market opportunities for MBG may improve as European small scale oxygen plants are introduced and proven in the U.S.)

- MBG single-user plants may be user-owned or operated by an independent owner/operator in an over-the-fence contract arrangement.

Medium-Btu multiple-user plants constitute the third likely configuration. The entire gasification complex is centrally located. Gas is distributed in a dedicated pipeline over distances of 100 to 200 miles maximum, according to economic studies by architect/engineering firms.

- There are no limitations to the number of users of a large-scale MBG facility 
EXHIBIT $V-2$

Expected Equipment Configurations for

Industrial LBG and MBG Applications

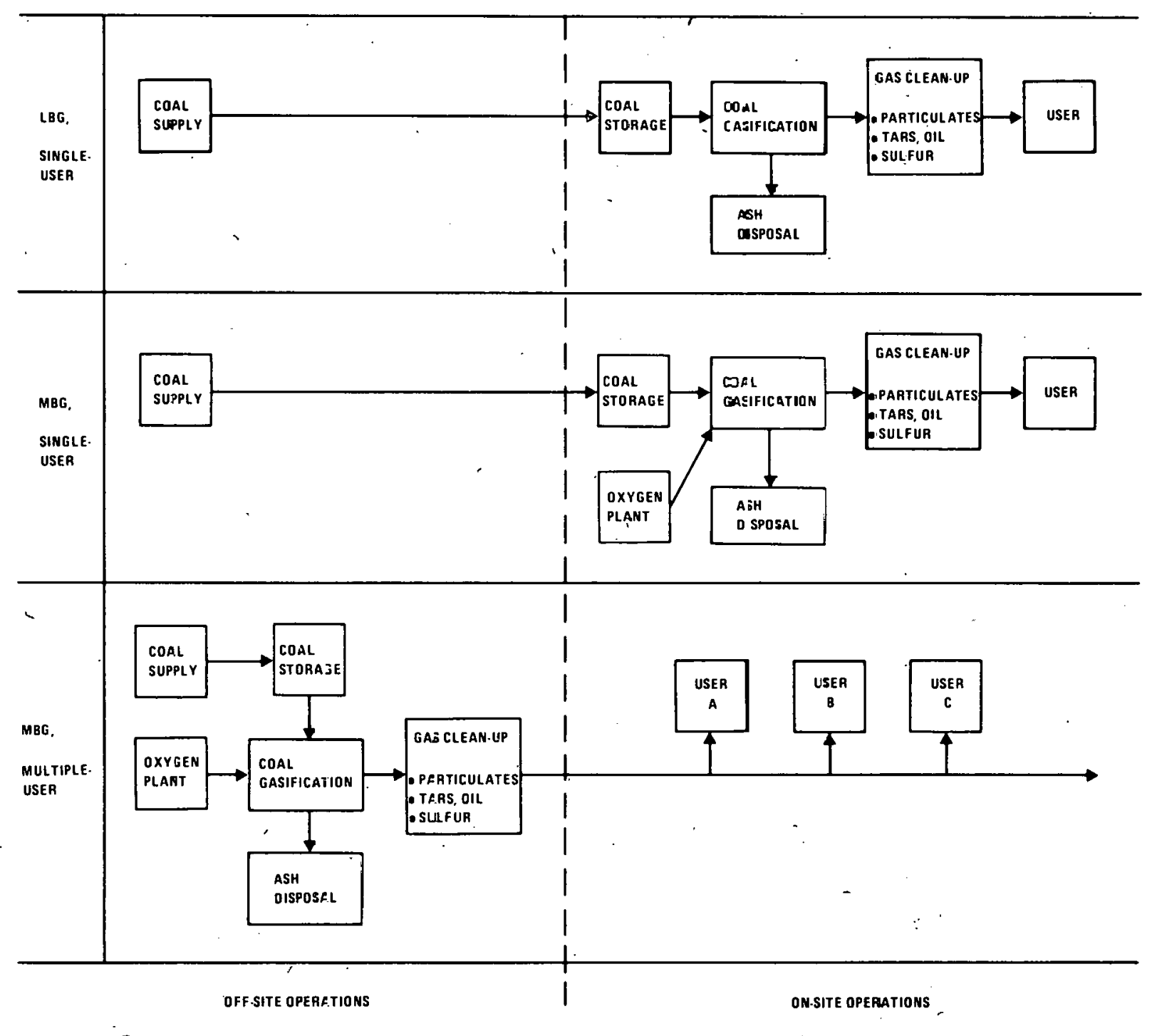


- A key uncertainty is who will be the "patron" of large scale MBG plants. Owner/operators have been suggested in previous studies to be a consortium of users, coal producers, gas utilities and pipeline companies, and special venture financial companies.

The three key gasification configurations are the subjects of further analysis to determine feasible market size.

2. FOUR KEY. CRITERIA CONĆERNING THE USE OF THE GAS AND

THE UTILIZATION OF THE GASIFIER BOUND THE MAXIMUM MARKET SIZE

To determine which industries--and which energy applications within each industry--actually provide reasonably feasible potential for LBG and MBG coal gasification, a set of foúr measures have been utilized, as shown in Exhibit V3:

- Technical fit of the gas itself:

- Flame characteristics

- Chemical composition

- Sufficient end-use plant demands to achieve adequate gasifier utilization:

- Annual energy requirements

- Load factor (demand constancy).

(1) Low-Btu Gas Exhibits Different Flame Characteristics Than Natural Gas, Reducing Its Range of Feasible Applications, Although Medium-Btu Gas Flame Characteristics Are Similar to Those of Natural Gas

LBG can attain flame temperatures of only $2800^{\circ}$ $3000^{\circ} \mathrm{F}$, even with preheating. Industrial processes requiring flame-tip temperatures in excess of $3000^{\circ} \mathrm{F}$ cannot consider LBG as an option.

In retrofit applications requiring specific flame shapes, heat release rates, and luminescence standards, substantial burner adjustments may be necessary to accommodate LBG:

Flue volumes 115 percent to 20 percent greater than natural gas cause the need for system retrofit. 
EXHIBIT V-3

- Feasibility Criteria for Industrial LBG and MBG Coal Gasification

\section{Gas}

Characteristics

\begin{tabular}{|c|c|c|c|}
\hline & Low-Btu, jingle-User & Medium-Btú, single-User & Medium-Btu, Multiple User \\
\hline $\begin{array}{l}\text { Flame } \\
\text { Characteristics }\end{array}$ & $\begin{array}{l}\text { Can attain maximum flame } \\
\text { temperatures of } 2800^{\circ-} \\
3000^{\circ} \mathrm{F} \text {, even with pre- } \\
\text { heating; flame quality } \\
\text { control problems possible }\end{array}$ & \multicolumn{2}{|c|}{$\begin{array}{l}\text { Can a-tain flame temperatures of } 3500^{\circ}- \\
3700^{\circ} \mathrm{F} \text {; 1 imited flame control problems, } \\
\text { if any }\end{array}$} \\
\hline $\begin{array}{l}\text { Chemical } \\
\text { Composition }\end{array}$ & $\begin{array}{l}\text { High inert sontent (about } \\
50 \text { percent nitrogen) }\end{array}$ & \multicolumn{2}{|c|}{$\begin{array}{l}\text { Inert content much lower; hydrogen and } \\
\text { carbon monoxide comprise } 70-90 \text { percent }\end{array}$} \\
\hline $\begin{array}{l}\text { Level of } \\
\text { Energy } \\
\text { Consumption }\end{array}$ & $\begin{array}{l}\text { Users will be limited by } \\
\text { smallest conmercially } \\
\text { available gasifier; } \\
\text { about } 0.5 \text { billion Btu/ } \\
\text { day with Bituminous feed, } \\
\text { about } 200-300 \text { million } \\
\text { Btu/day with Anthracite }\end{array}$ & $\begin{array}{l}\text { Minimum realistic size } \\
\text { gasification plant esti-- } \\
\text { mated at abou: } 8 \div 10 \text { bil- } \\
\text { lion Btu/day, unless } \\
\text { oxygen source already } \\
\text { available }\end{array}$ & $\begin{array}{l}\text { Ability to run distribution } \\
\text { lines from gasification plant } \\
\text { to customers of all sizes }\end{array}$ \\
\hline $\begin{array}{l}\text { Load } \\
\text { Patterns }\end{array}$ & $\begin{array}{l}\text { Feasible applications } \\
\text { generally require high } \\
\text { plant load =actors, at } \\
\text { least in the range of } \\
\text { about } 60-70^{\circ} \text {. }\end{array}$ & $\begin{array}{l}\text { Feasible appl cations } \\
\text { generally require high } \\
\text { plant load factors, at } \\
\text { least in the range of } \\
\text { about } 70-80 \% \text {. }\end{array}$ & $\begin{array}{l}\text { Load diversity of multiple } \\
\text { customers eliminates require- } \\
\text { ments for minimum capacity } \\
\text { factor }\end{array}$ \\
\hline
\end{tabular}

Plant

Characteristics 
- High inert content--about 50 percent nitrogen-makes temperature control difficult.

However, MBG can achieve flame temperatures in the range of $3500^{\circ}$ to $3700^{\circ} \mathrm{F}$, equivalent to or slightly higher than those of natural gas, and can therefore be applicable in even very high. temperature processes. Slight differences in combustion and flue volumes for MBG and natural gas will require minimal piping and burner adjustments, if any.

(2) The Chemical Composition of Low-Btu Gas Diminishes Its Suitability for Feedstock and Other Applications : MBG Can Be Used for Both Fuel and Feedstock Purposes

The high inert composition of LBG reduces its feedstock value significantly, versus that of natural gas (principally $\mathrm{CH}_{4}$ ):

- About 50 percent nitrogen

- 20 percent to 25 percent carbon monoxide

- 15 percent to 20 percent hydrogen.

The use of LBG is not feasible in applications where specific combustion atmospheres are required. For example:

- In blast furnaces where a low nitrogen atmosphere is required

- In metal fabricating processes requiring ambients free of trace elements such as vanadium.

MBG's chemical composition is compatible with both. fuel and feedstock application in all chemical syntheses fed by natural gas, and typically includes:

35 percent to 50 percent carbon monoxide

30 percent to 40 percent hydrogen

10 percent to 20 percent carbon dioxide. 
(3) Single-User Gasification Is Not Generally

Feasible for Industrial plants With Low Levels of Energy Consumption

Industrial plants with fossil fuel consumption of less than about $0.2-0.3$ billion Btu/day are unlikely targets for LBG.

- With an anthracite feed, the smallest commercially operational gasifier unit produces about 0.2 billion Btu/day of LBG.

- With bituminous or other coal feed, the smallest commercially available unit supplies about 0.5-0.6 billion Btu/day.

- At usage levels much below 0.5 billion Btu/ day, propane may be the more attractive alternative, even according to a gasifier vendor.

Single-user MBG with commercially available equipment will not generally be feasible in industrial plants with fuel consumption of less than about 8-10 billion Btu/day.

- Accepted minimums for economically sized oxygen plants make the cost of an MBG-oxygen facility incur severe scalc pcnalticc at MBG capacities much below 8-10 billion Btu/day.

- One major manufacturer will not provide quotes for plants with capacities less than 10 billion Btu/day.

- The commercial scale capacities expected for the new entrained-flow gasifiers--Texaco and Combustion Engineering--are of the same order - of magnitude as those of existing processes.

However, the minimum MBG plant scale requirements stated above can be relaxed in some cases, and will not hold under two conditions:

- If the industrial plant currently has ain available oxygen source with undedicated capacity 
- If the smaller scale oxygen plants now appearing in Europe gain acceptance in the U.S.

An important observation is that multiple-user MBG can serve industrial customers of all sizes:

- Dedicated mains can easily distribute gas to any user accessible to the pipeline.

- Because individual energy demands are additive, no scale requirements are placed on MBG users.

(4) Low Load Factors Reduce the Basic Economic Feasibility of Gasification in Industrial Applications

The significant capital costs of gasification indicate that a high utilization rate, or load factor, is a requisite for practical applications of LBG or MBG.

- The allocated capital costs for LBG range from about 30 percent to 45 percent of total gas costs, as shown in Exhibits III-10, 11 and 12 .

- The capital costs for MBG ranges from about 30 percent to 60 percent of total gas costs, as shown in Exhibits III-13 and 14 .

The importance of maintaining high load factors is greater for single-user MBG plants than for LBG-plants. Although the level of necessary load factors would vary on a case-by-case basis, economic MBG facilities would be expected to operate in at least the 70-80 percent load factor range, and LBG plants in at least the 6070 percent range. The high capital costs of the oxygen facility indicate that each unit of gas must bear a higher capital charge than gas from an LBG plant.

For multiple-user MBG configurations, individual customer load factors are less important. Load diversity among multiple users will generally ensure high utilization.

Application of these characteristics of LBG and MBG to feasibility analysis is presented in the following two sections. 
3. ANALYSIS OF INDUSTRIAL APPLICATIONS INDICATES THAT MBG IS USABLE IN NEARLY ANY SITUATION, WHILE LBG IS UNSUITABLE FOR FEEDSTOCK AND HIGH TEMPERATURE APPLICATIONS

This section focuses on the feasible applications of LBG and MBG. As shown in Exhibit V-4, there are a variety of end uses:

- MBG is applicable to process heat, boiler fuel, electric power-generation, chemical feedstock and input to SNG reduction

- LBG is applicable only to industrial fuel uses, and with several limitations.

\section{(1) MBG Has Few Limitations on Use}

The key characteristics of MBG are high hydrogen and carbon monoxide content with varying actual ratios, a low inert (nitrogen) component, a low methane concentration (except in the Lurgi process) and heating values, about 270-300 Btu/scf., as shown in Exhibit V-5. These characteristics lead directly to conclusions on the nature of attractive applications: Flame temperatures approximate those from
- natural gas

- MBG has excellent potential as a chemical feedstock, particularly for

- Methanol, which requires an attractive $2: 1$ ratio of $\mathrm{H}_{2} / \mathrm{CO}$

- Ammonia, which requires pure $\mathrm{H}_{2}$ under pressure. (The Lurgi process produces about 9 percent methane and needs reforming. Conversely, Koppers Totzek output contains little methane, requires no secondary reforming, tut needs compression)

- Urea and related products.

1. Although volume requirements are greater than for natural gas, pipeline transmision up to 200 miles is believed by a number of suppliers to be economically feasible. 
Potential Market Applications of LBG and MBG

GAS TYPE

CATEGORY OF USE

APPLICATIONS

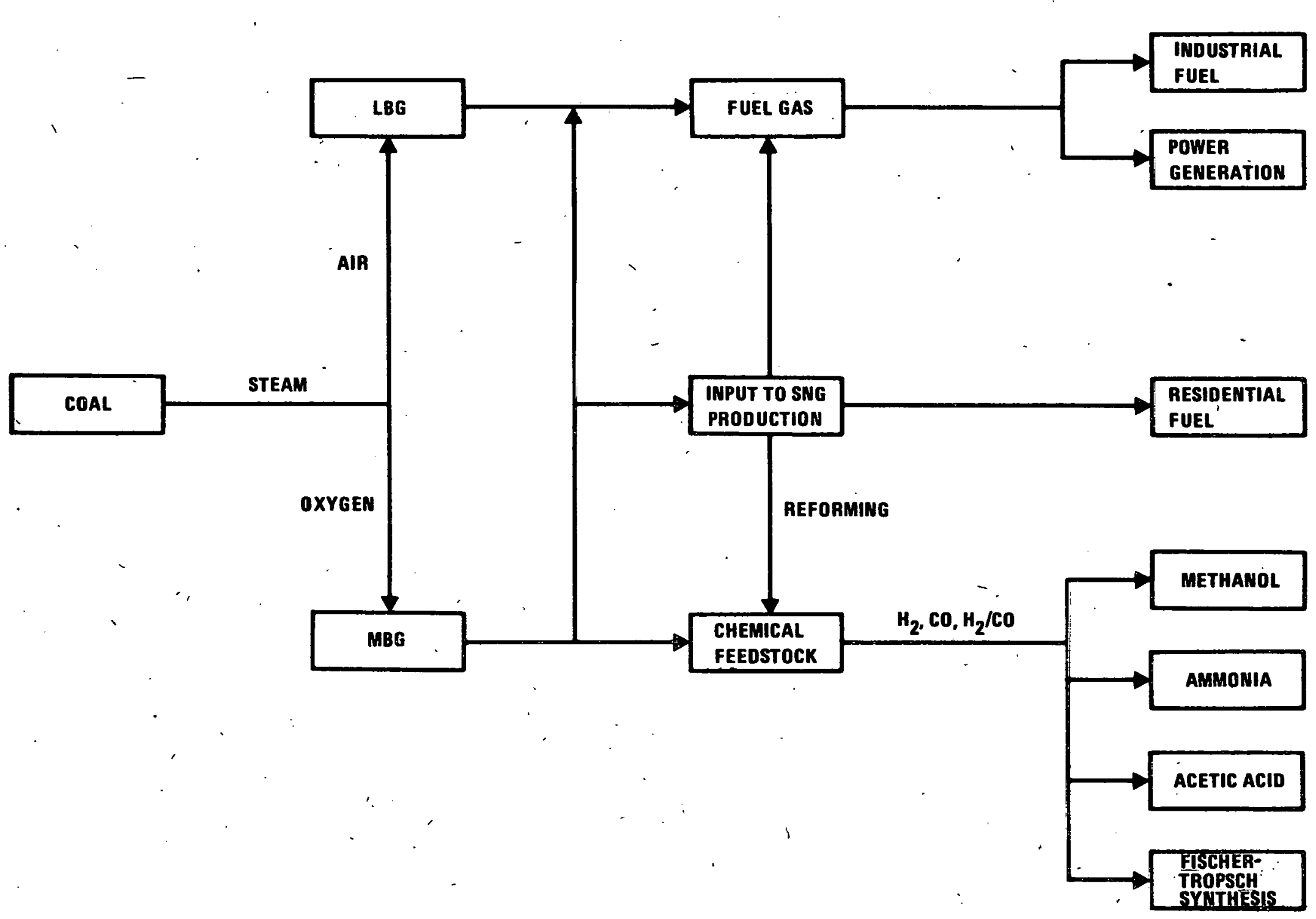


EXHIBIT $V-5$

Uses of Medium-Btu Gas

\section{CHARACTERISTICS}

- High hydrogen and carbon monoxide concentration, about (75 5 ? $3 \%)$

- Varying $\mathrm{H}_{2} / \mathrm{CO}$ ratios

- Low inert material concentration

- Low methane concentration, except in Lurgi ga:

- Higher heating values around 280 . Btu/scf

\section{LEAUING TO}

- Being transportable up to 200 miles, hence multiplant supply possible

- Flame temperatures marginally lower or higher than natural gas $( \pm 5 \%)$ due to high adiabatic temperatures of $\mathrm{H}_{2}$ and $\mathrm{CO}$

- Good value as a chemical feedstock although specific compositions fit better particular applications

- All industries

- Chemical industry

- Gas industries

- All industries

- Iron \& steel

- Paper \& pülp

- Glass industry

- Primary metals

\section{APPLICABLE IN}

LBG applications

Feeds tock

SNG production

Direct firing of finished products; automated heating systems; firing of flow through radiant burners; indrect tired furnaces

Blast furnace injection

Paper and print drying

Glass tanks; cutting, annealing ; and scrapping

Finish annealing operations; flat flame burners; partial premix burners 
Based on these characteristics, medium-Btu gas is a versatile and technically attractive fuel and feedstock, for industrial use.

(2) Low-Btu Gas Has More Limited Feasible Uses Due to Flame Temperature, Flue Volumes and Chemical Composition

The key characteristics of LBG are high nitrogen content, low carbon monoxide and hydrogen content and heating values near $150 \mathrm{Btu} / \mathrm{scF}$, as Iisted in $\mathrm{Ex}-$ hibit $v-6$.

Based on these characteristics, LBG is limited to on-site use (no transmission), and is limited in the temperature range of industrial applications due to flame temperatures about 13 percent. Iower than natural gas. Further, LBG is unsuitable for chemical feedstock use. Finally, the high flue volumes indicated by low energy density imply significant retrofit of existing combustion systems.

However, LBG is basically, suitable for the large number of industrial fuel uses which operate well at temperatures less than $2800^{\circ}-3000^{\circ} \mathrm{F}$. For application below temperature limits, the key issue is the extent and cost of retrofitting required. Today, there are operating and planned LBG gasifiers in the U.S. for

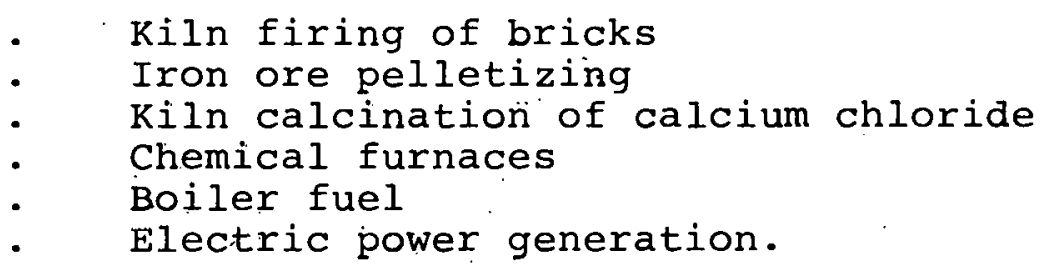

The assessment of the feasibility of industrial applications of LBG and MBG continues in the following section. Throughout this discussion, it should be noted that the feasibility of individual applications depends on; a variety of site-specific issues as well as the generic industry factors considered here. 
EXHIBIT $V-6$

Uses of Low-Btu Gas

\section{CHARACTERISTICS}

- High nitrogen concentration, around $50 \%$

- Low hydrogen and carbon monoxide concentrations, between 35 and $45 \%$

- Heating values of $(150 \pm 25)$ Btu/scf

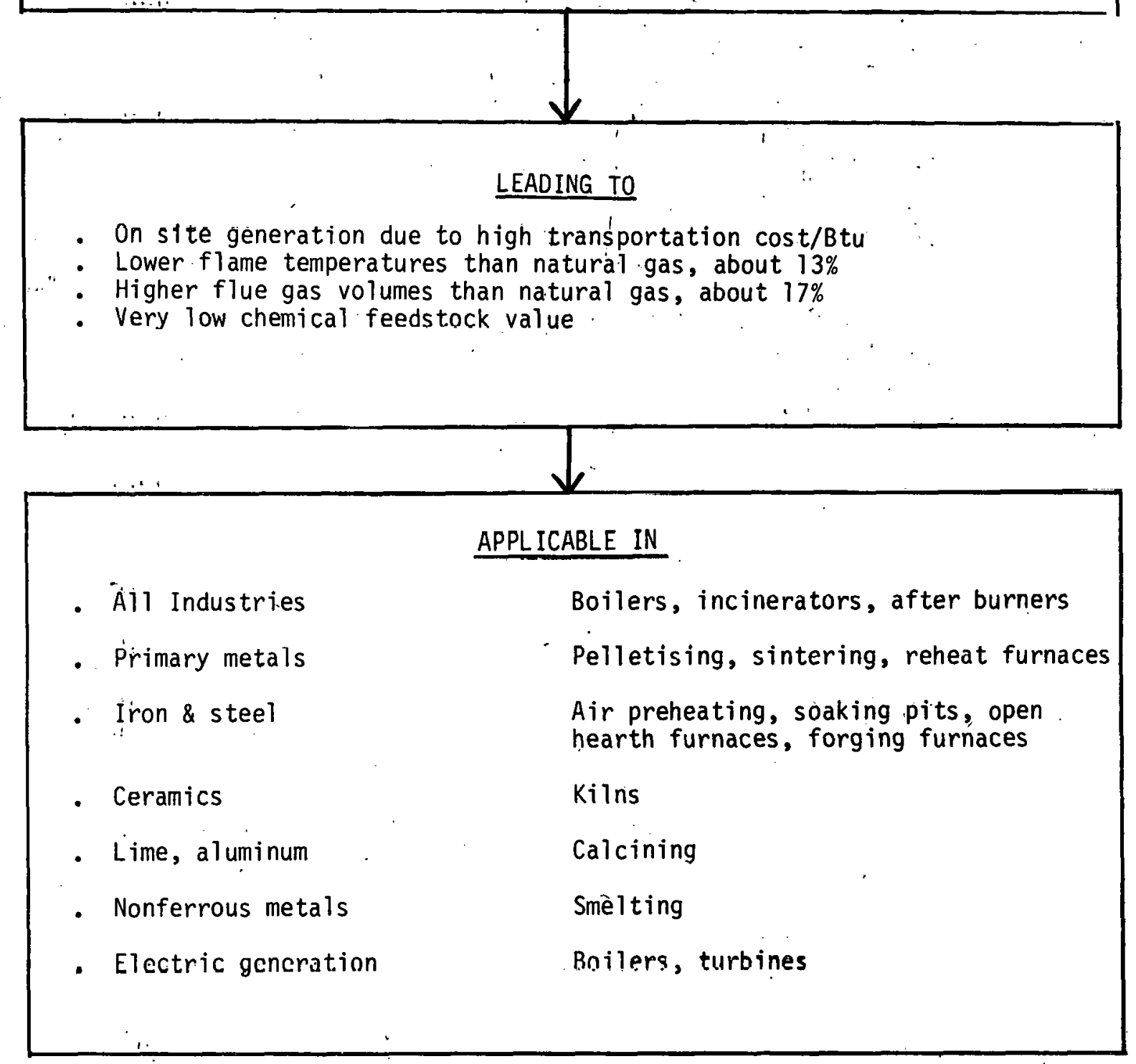


4. THE FEASIBLE MARKET FOR LOW- AND MEDIUM-BTU GASIFICATION INCLUDES APPLICATIONS IN MOST MAJOR ENERGY-CONSUMING INDUSTRIES

An industry-by-industry assessment of the feasibility of low- and medium-Btu gasification, based on the four measures developed previously, indicates that the feasible market for low- or medium-Btu gas consists of a wide range of applications throughout the industrial sector. Industries examined in this section include the nation's five largest energy-consuming industries, and selected other industries identified in recent studies as being potential gasification targets. Summary conclusions for the five largest industries are as follows:

MBG is a highly feasible chemical feedstock and process fuel, although LBG is limited to fuel use in the chemicals industry

- MBG is easily adaptable to integrated steel mill processes, although LBG is less feasible due to the chemical composition of the gas and potentially complex retrofit requirements

- MBG is generally infeasible in all but a few large pulp and paper plants, while LBG is more widely feasible

- MBG can feasibly be used in petroleum refining, since refineries are designed for varying fuel quality. LBG is also feasible, but subject to potentially complex process retrofitting

- For the cement industry, MBG is feasible if supplied by a multiple-user gasifier, while LBG feasibility is Iimited by process temperature requirements.

- The fabricated metal products and motor vehicle industries can use medium-Btu gas, but singleuser applications are limited by inadequate plant capacities and poor load factors

- Although glass industry plants are generally too small for single-user MBG, the use of MBG from multiple-user gasifiers is attractive. The feasibility of LBG is somewhat limited 
EXHIBIT $\mathrm{V}-7$

Summary Screening Ȧnalysis For. Feasibility

\begin{tabular}{|c|c|c|}
\hline \multirow[b]{2}{*}{ INOUSTAY } & \multicolumn{2}{|c|}{ LOW-BTU JASIFICATION } \\
\hline & $\begin{array}{c}\text { FLAME CHARACTERISTICS } \\
\text { AND } \\
\text { CHEMIZAL COMPOS TION }\end{array}$ & $\begin{array}{l}\text { CAPACITY } \\
\text { UTILIZATION }\end{array}$ \\
\hline FOOD & - & $\ominus$ \\
\hline TEXTILES & - & $\ominus$ \\
\hline PAPER & - & $\odot$ \\
\hline CHEMICALS & $\ominus$ & - \\
\hline PETROLEUM & - & - \\
\hline GLASS & $\ominus$ & - \\
\hline CEMENT & $\ominus$ & $\ominus$ \\
\hline BRICK & - & $\ominus$ \\
\hline BASIC STEEL & - & - \\
\hline $\begin{array}{l}\text { ALUMINUM, } \\
\text { NON-FERFOUS }\end{array}$ & - & $\bullet$ \\
\hline $\begin{array}{l}\text { FABRICATEL } \\
\text { METALS }\end{array}$ & - & $\ominus$ \\
\hline
\end{tabular}

\begin{tabular}{|c|c|}
\hline \multicolumn{2}{|c|}{ MEDIUM-BTU GASIFICATION } \\
\hline $\begin{array}{c}\text { FLAME CHARACTERISTICS } \\
\text { AND } \\
\text { CHEMICAL EOMPOSITION }\end{array}$ & $\begin{array}{c}\text { CAPACITY } \\
\text { UTILIZATION } \\
\text { ISINGLE.USER ONLY) }\end{array}$ \\
\hline$\bullet$ & 0 \\
$\bullet$ & 0 \\
$\bullet$ & $\bullet$ \\
$\bullet$ & $\bullet$ \\
$\bullet$ & $\bullet$ \\
$\bullet$ & 0 \\
$\bullet$ & $\bullet$ \\
$\bullet$ & 0 \\
$\bullet$ & $\bullet$ \\
$\bullet$ & $\bullet$ \\
$\bullet$ & \\
\end{tabular}

\begin{tabular}{|c|c|c|}
\hline \multicolumn{3}{|c|}{ SUMMARY FEASIBILITY } \\
\hline L.JW.BTU & $\begin{array}{c}\text { MEDIUM-BTU } \\
\text { SINGLE-USER }\end{array}$ & $\begin{array}{c}\text { MEDIUM-BTU, } \\
\text { MULTIPLE.USERS }\end{array}$ \\
\hline$\bullet$ & 0 & $\bullet$ \\
$\bullet$ & 0 & $\bullet$ \\
$\ominus$ & $\bullet$ & $\bullet$ \\
$\ominus$ & $\bullet$ & $\bullet$ \\
$\bullet$ & $\bullet$ & $\bullet$ \\
$\ominus$ & 0 & $\bullet$ \\
$\ominus$ & $\bullet$ & $\bullet$ \\
$\ominus$ & 0 & $\bullet$ \\
$\bullet$ & $\bullet$ & $\bullet$ \\
$\bullet$ & $\bullet$ & $\bullet$ \\
$\ominus$ & $\bullet$ & $\bullet$ \\
\hline
\end{tabular}

KEY: : INDUSTRY MEETS CRITERION

: INDUST TY MEETS CRI'ERION IN PART

O: INDUST BY DOES NOT MEET CRITE ZION

SOURCE: BASED ON EXHIBIT V-8 
The brick and structural clay tile industry can feasibly apply either medium-Btu gas from a shared facility, or low-Btu gasification

- The primary aluminum and non-ferrous metals industry can realistically consider both MBG and LBG in most energy-consuming applications

- The food industry could utilize MBG gas from a multiple-user facility, but will be limited in considering either LBG or MBG from a single-user plant

- Although textile mills are not likely to be feasible targets for single-user LBG or MBG, applications of gas from a multip̈le-user MBG plant are feasible.

More detailed information on specific industrial applications is provided in the following discussion. Exhibit $V-7$ provides an overview of the analysis contained in this section, and Exhibit $V-8$ presents comparative data on the feasibility of LBG and MBG applications in each industry, as determined by the four key feasibility criteria.

(1) MBG Is a Highly Feasible Chemical Feedstock and Process Fuel, Although LBG Is Limited to Fuel Use in the Chemicals Industry

Medium-Btu gas can be used widely as both a fuel and a feedstock in the chemical industry. MBG can readily replace natural gas fuel, according to industrial discussions, in both boilers and furnaces, which account for about 40 percent of the energy usage in the industry.

In feedstock applications, which consume about 55. percent of the oil and gas used in the industry, $M B G$ is a feasible--and sometimes more efficient--substitute for natural gas due to its:

- High $\mathrm{H}_{2}$ and $\mathrm{CO}$ concentration, about 65-90 percent

- Low methane content

Low diluent content. 


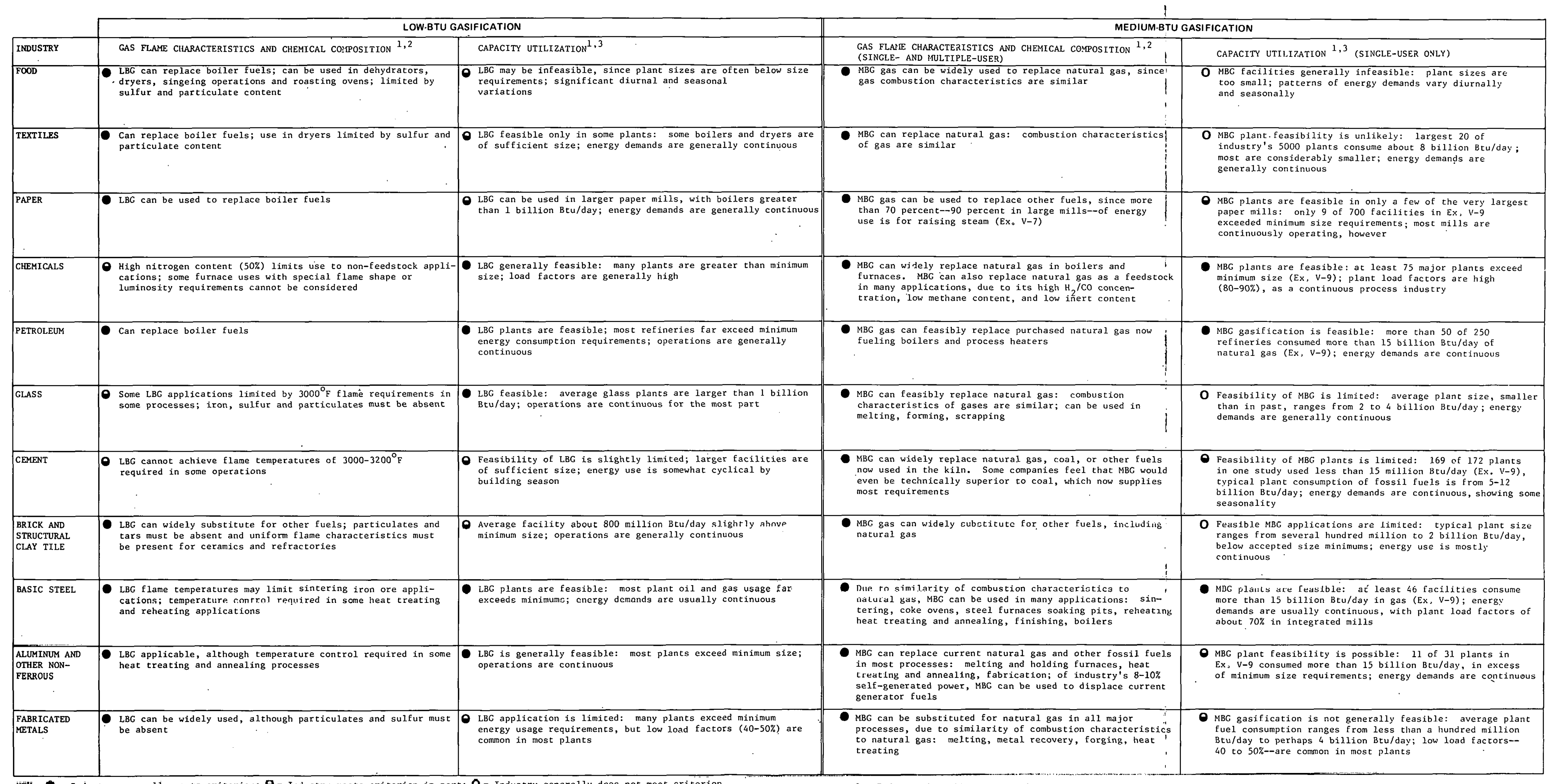

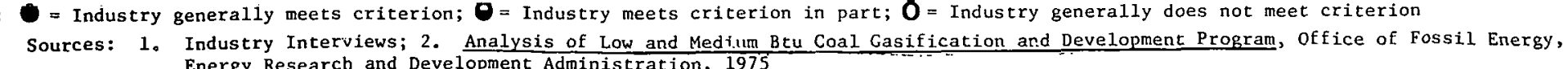

3. Industrial Applications Study: Industrial Plant Survey, Energy Research and Development Administration, 1977 
Likely feedstock applications will, as indicated in industry interviews, include:

- Methanol

- Ammonia

- Acetic acid

- Ethylene glycol

- Other commodity chemicals.

Medium-Btu gasification is feasible in single-user as well as multiple-user configurations since the chemical industry'meets the necessary size and load factor criteria for MBG gasifiers:

Chemical plant energy consumption typically ranges from several hundred million to more than 60 billion Btu/day.

At least 75 major chemical plants consume in excess of 15 billion Btu/day, as shown in Exhibit $V-9$.

As a.continuous process industry, load factors in the chemical industry are high, frequently in excess of 80 percent to 90 percent.

Low-Btu gas can be utilized for boiler and thermal process fuel purposes but will be severely limited in feedstock applications due to:

- Low $\mathrm{H}_{2} / \mathrm{CO}$ content, generally from 35 percent to $45^{2}$ percent combined

- High inert content, about 50 percent $\mathrm{N}_{2}$.

Low-Btu gasification is otherwise feasible in terms of the two utilization criteria for LBG gasifiers: Plant fuel usage generally far exceeds minimum gasifier scale requirements.

- Plants have high load factors. 
(2) MBG Is Easily Adaptable to Integrated steel Mill Processes, Although LBG Is Less Feasible Due to

the Chemical Composition of the Gas and Potentially Complex Retrofit Requirements

Medium-Btu gas can be applied in most of the steel industry's major energy-consuming processes, as indicated in industrial interviews, due to the similarity of its combustion characteristics to those of natural gas. MBG can be used directly or mixed with available coke oven gas. Feasible applications include:

- Sintering

- Coke ovens

- Steel furnaces

- Soaking pits

- Reheating

- Heat treating and annealing

- Finishing

- Boiler fuel.

Integrated steel mills are generally large and complex enough to accommodate and utilize an economically scaled sole-user MBG gasifier.

Flant purchascd fucl conoumption uoually ranges from 10 billion to more than 60 billion Btu/day.

- There are nearly 50 steel plants which consume more than 15 billion Btu/day of natural gas alone, as seen in Exhibit $v-9$.

- Energy demands are cyclical but nearly continuous.

- Existing plant gas distribution systems now pipe lower-energy by-product gases, including:

- Coke oven gas, about 500-550 Btu/scf

- Blast furnace gás, about $90 \mathrm{Btu} / \mathrm{scf}$.

Low-Btu gas can be used in most of the industry's process heat applications, but retrofit applications may require significant combustion equipment adjustments, due to:

- Higher flue volumes

- Lower flame temperatures. 
EXHIBIT $V-9$

Industrial Plant Consumption of Natural Gas for Fuel and Feedstock Uses

\begin{tabular}{|c|c|c|c|c|c|c|c|}
\hline \multirow[b]{2}{*}{ Industry } & \multirow{2}{*}{$\begin{array}{l}\text { Number } \\
\text { of Plants }\end{array}$} & \multicolumn{6}{|c|}{$\begin{array}{l}\text { Number of Plants With Consumption in Each Range } \\
\text { (Billion Btu's/Day) }\end{array}$} \\
\hline & & $3-15$ & $15-30$ & 33 & -60 & $64-90$ & $>90$ \\
\hline Chemicals & 230 & 154 & 43 & & 23 & 8 & 2 \\
\hline Iron and Steel & 187 & 141 & 20 & & 22 & 2 & 2 \\
\hline Paper .. & 727 & 718 & 9 & & - & - & - \\
\hline $\begin{array}{l}\text { Petroleum } \\
\text { Refining }\end{array}$ & 258 & 201 & 33 & & 16 & 0 & $\cdot 8$ \\
\hline Cement & 172 & 169 & 3 & & 0 & 0 & 0 \\
\hline Aluminum & 31 & 20 & 7 & & 1 & 1 & 2 \\
\hline Total & 1605 & 1403 & 115 & & 62 & 11 & 14 \\
\hline
\end{tabular}

Source: Data Sources and Methods for Industrial Energy Analys is, Energy \& Environmental Analysis, Inc., January 1977. 
In addition, blast furnace applications of LBG may be unsuitable, because of two factors:

- High diluent nitrogen content

- Limited carbon content.

The steel industry meets the feasibility criteria for economic utilization of LBG gasification:

- Typical fossil fuel usage per plant far exceeds gasifier minimum requirements.

- Load factors in the industry are high.

(3) MBG Is Generally Feasible only in Larger Pulp and Paper Mills, While LBG Is More Widely Feasible

Medium-Btu gas can, on technical grounds, substitute for most of the fuel used in the paper industry. MBG can be used to fire boilers, which account for more than 70 percent of the energy used in the industry. Major processes include:

$$
\begin{aligned}
& \text { - Digestors } \\
& \text { - } \quad \text { Evaporators } \\
& \text { Pulp dryers. }
\end{aligned}
$$

MBG can also be used in several smaller direct heat applications:

$$
\begin{array}{ll}
\text { - } & \text { Lime kilns } \\
\text { - } & \text { Soating } \\
& \text { Specialized dryers. }
\end{array}
$$

However, MBG gasification is likely to be infeasible in all but the largest paper or pulp mills due to three factors:

Typical plant fossil fuel consumption exceeds 10 billion Btu/day only in the larger integrated mills.

Only 9 of more than 700 paper industry facilities investigated consumed more than 15 billion Btu/ day, as shown previously in Exhibit V-9. 
- Many mills are remote from major industrial areas, reducing the likelihood that a multiple-user MBG facility can feasibly pipe gas to such locations.

Low-Btu gas can generally be utilized in most energy applications in the paper industry:

- Boilers can be fired with LBG, although minor retrofit adjustments may be necessary to avoid deratings.

- Direct heat applications, although retrofit will be needed.

Low-Btu gasifiers can achieve adequate utilization in most paper mills:

- Plant energy consumption exceeds gasifier minimum requirements.

- Energy demands are seasonal but generally continuous.

However, both LBG and MBG applications in the paper industry will be limited by the growing use of by-product forest wastes:

- Forest wastes and liquors now supply about 45 percent of the industry's energy requirements.

- The proportion is expected to rise above 50 percent in the near future.

(4) MBG Can Feasibly Be Used in Petroleum Refining, Since Refineries Are Designed for Varying Fuel Quality. IBG Is Also Feasible, But subject to Potentially Complex Process Retrofitting

Medium-Btu gas can replace natural gas in its significant applications in refining. As pointed out in industrial discussions, the combustion similarities of MBG and natural gas indicate that MBG can be readily utilized in the two largest energy-consuming processes:

Crude distillation

- Hydrogen reforming. 

cesses:

MBG can replace natural gas in other major pro-

- Delayed coking
- $\quad$ traight distillation
Hydrotreating.

Both boilers and process furnaces can utilize lower energy gas since combustors are generally designed to be able to utilize fuel inputs of varying qualities, and since the gae aan easily bc mixcd with refincry off-gas. Refinery gas generally ranges between 900 and $1400 \mathrm{Btu} /$ scf--but can range from as low as 300 to as high as $2000 \mathrm{Btu} / \mathrm{scf}--$ in heat content.

MBg yasificatiun is feasible in refining in lenms of the industry's ability to achieve economic utilization of the gasifier:

- More than 50 of about 250 refining facilities examined in one study consumed more than 15 billion Btu/day of natural gas, as shown in Exhibit V-9.

- Refinery operations are generally continuous on both a daily and seasonal basis, although the mix of fuels used may vary by season.

Low-Btu gas can technically be applied in the major energy-consuming processes identified above. However, significant retrofitting may be required to utilize the gas without derating, due to:

$$
\begin{aligned}
& \therefore \quad \text { Higher flue volume } \\
& \text { Additional piping } \\
& \text { Lower heat content. }
\end{aligned}
$$

Low-Btu gasification plants can achieve minimum utilization requirements without difficulty:

- Llant-purchásed fuel usage far exceeds small gasifier output levels.

- Plant energy usage is nearly continuous.

However, the penetration of both low- and mediumBtu gasification will be limited by the availability of by-product energy sources in the industry, including: 


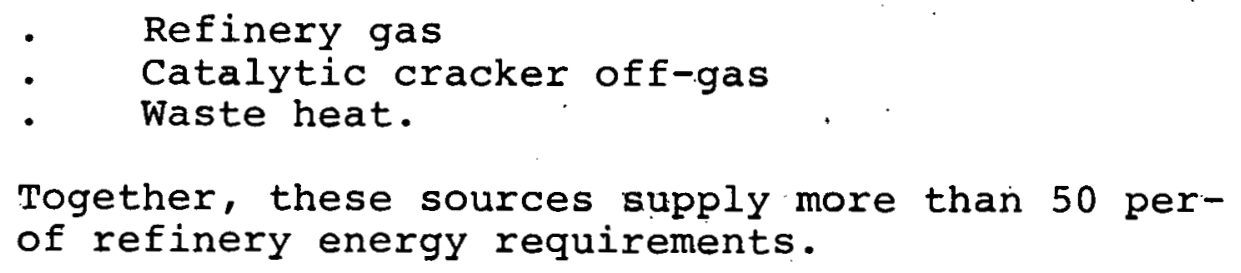

(5) For the Cement Industry, MBG Is Feasible If Supplied By a Multiple-User Facility, But LBG Feasibility Is Limited By Process Temperature Requirements

Medium-Btu gas itself is feasible in the industry, according to industry interviews, but the scale-requirements for an MBG gasifier indicate that applications will be limited to sharing a multiple-user facility's output, for several reasons:

- MBG gas can be used in the industry's rotary kilns, to fire the raw materials to produce clinker. Approximately 80 percent of the industry's energy use is in kilns.

- Typical piant fuel consumption averages from 5 to 12 billion Btu/day.

- As shown previously in Exhibit V-9, only 3 of 172 cement plants surveyed indicated natural gas usage in excess of 15 billion Btu/day.

- The industry's operations are substantially cyclical by season, posing an issue of sufficient plant utilization.

Low-Btu gas has less technical applicability in the cement industry, due to its flame limitations:

- Rotary cement kilns reguire flame temperatures of at least about. $3000 \mathrm{~F}$, which is at the upper range of the capability of low-Btu gas, even with preheating:

- However, IBG can feàsibly be used in calcination processes, as National Lime and stone has shown.

Both MBG and LBG applications in the industry will be Iimited by the industry's growing use of direct coal combustion. 
- Direct coal firing can be quite attractive, due to favorable coal prices and the fact that combustion products--including ash and sulfur--are absorbed in the product.

- The industry is now reliant on coal for more 'than 70 percent of its energy' requirements, and the current trend is toward greater coal dependence.

(6) The Fabricated Metal products and Motor Vehicle Tndustries Can Use of Medium-Btu-Gas, But SingleUser Applications Will Encounter Some Difficulties

Medium-Btu gas can replace current natural gas applications in most direct heat and boiler processes in these industries, subject to several limitations:

- Although MBG's similarity to natural gas in flame characteristics indicates that its potential uses are wide, retrofitting of combustion equipment may be necessary in tempering and other processes, according to industry interviews.

Single-user MBG plants are generally less attractive than multiple-user facilities in these industries, due to two factors:

- Average plant fuel consumption is relatively small--generally from a few billion Btu/day to less than several hundred million Btu/day--and exceeds 10 billion Btu/day only in larger automobile manufacturing plants and foundries.

- Load factors of 40 percent to 50 percent are common in most plants, according to industry interviews.

Major processes where MBG could be feasible, assuming the use of a multiple-user facility, include:

$$
\begin{array}{ll}
\text { - } & \text { Melting } \\
\text { - } & \text { Metal recovery } \\
\text { - } & \text { Forging } \\
\text { - } & \text { Heat treating } \\
\text { - Coating, painting, and decorating. }
\end{array}
$$


Feasible low-Btu gasifier applications are anticipated to include unique situations in these industries, - for several reasons:

- In smalier plants, the minimum scale requirements will limit feasible LBG installations.

- In plants of all sizes operating in a batch processing mode, lower load factors may preclude economic operation of a gasifier.

- Some specialty metal processes will require flame temperatures beyond the range of lowBtu gas.

- LBG gasifiers can nonetheless be feasible in many metal working processes, although burner, piping, and other adjustments will be necessary.

(7) Although Glass Industry Plants Are Generally Too Smali for Single-User MBG, the Use of MBG From Multiple-User Gasifiers Is Attractive. The Feasibility of LBG Is Somewhat Limited

Medium-Btu gasification can technically supplant most natural gas applications in the gas industry:

- MBG gas combustion characteristics are similar to those of natural gas.

- About 70 percent of the industry's fuel consumption is for glass melting, which is reported to require minimal retrofitting to utilize MBG.

- Other thermal processes, including forming and annealing, may require more significant burner adjustments.

MBG facilities for single-users are beyond the scale of glass plants, indicating that a multiple-user MBG configuration is more likely. Single glass plant energy consumption typically ranges from less than 2 to about 4 billion Btu/day.

Low-Btu gasifiers can find feasible applications in most of the industry, although substantial problems may be encountered: 
- IBG gas can be used in melting and scrapping operations. However, preheating will be necessary to achieve needed flame temperatures, which can range up to about $3000^{\circ} \mathrm{F}$.

- Specialty forming, cutting, and annealing processes can use LBG, but only with extensive combustion system adjustments.

- The 1evel of typical plant fuel consumption. and the pattern of energy demands are adequate to support at least a minimally scaled LBG gasifier.

(8) The Brick and Structural Clay. Tile Industry Can Feasibly Apply Either Medium-Btu Gas From a Shared Facility, or Low-Btu Gasification

Medium-Btu gasification is compatible with energyconsuming processes in the brick industry, but can be considered only if supplied by a multiple-user facility:

- The predominant use of energy in the industry is for firing atructural clay pivducls ill kilns. Although some flame control requirements must be met to ensure proper brick coloring, industry interviews indicate that both LBG and MBG will fulfili these specifications.

- An MBG facility dedicated to a sole user is not feasible in the brick industry since typical plant energy consumption ranges from several hundred militon to only approximately 2 billion Btu/day. The use of gas from a multi-plant facility is, therefore, the only feasible option for considering MBG.

Low-Btu gasffication can feasibly be applied in the brick industry, as indicated by several factors:

The gas itself can be used to fire the kilns, although retrofit. costs may be high in kilns designed with a large number of small burners. 
- The industry can achieve adequate utilization. of the gasifier system:

- Energy consumption per plant typically exceeds the production levels of LBG gasifiers.

- Fuel demands are generally flat, on both a seasonal and diurnal basis.

- The recent experience of Glen-Gery provides operational evidence that LBG can be used in the brick industry.

However, the industry's investigations of, and initial movement towards, direct coal combustion'indicate that the feasible market for gasification may be diminishing.

(9) The Primary Aluminum and Non-Ferrous Metals Industry Can Realistically Consider Both MBG and LBG in Most. Energy-Consuming Applications

Medium-Btu gasification can be utilized by the aluminum industry in both single-user and multiple-user configurations. MBG can replace natural gas in fuelfired processes such as:

- Melting and holding furnaces

- Heat treating and annealing

- Fabrication.

Although the industry's largest energy-consuming process--alumina reduction--relies mostly on electrolytic smelting, both MBG and LBG can be used to displace fuels now used to self-generate electricity:

- Electricity accounts for about 68 percent of the aluminum industry's energy use.

- Of.this, about 8 percent to 10 percent is selfgenerated.

The level and pattern of fossil fuel use in the industry indicate that even a single-user MBG facility can be adequately utilized: 
- Of 31 aluminum plants surveyed, as shown previously in Exhibit V-9, 11 used more than 15 billion Btu/day of natural gas alone.

- Industry energy demands are cyclical but nearly continuous.

Low-Btu gasification is feasible for major aluminum industry fuel applications, in light of the following factors :

- LBG can be used in the direct heat applications listed above, although combustion system retrofitting may be necessary.

- Low-Btu gas can be used to generate power tor the industry.

- Plant fuel use and load patterns will achieve economic gasifier utilization.

(10) The Food Industry Could Utilize MBG Gas From a Multiple-User Facility; But Will Be Limited in Considering Either LBG or MBG From a singleUser Plant

Medium-Btu gas itself can be widely used in the food industry to replace natural gas. Amonq major energy-consuming processes in the industry, MBG can be used in:

- Dehydrators
- $\quad$ Dryers
- $\quad$ Roastingeing ovens
- Boilerg

The food industry, however, is precluded from considering MBG in a single-user configuration. although sharing the output of a multiple-user facility is possible. Plant size is the major factor limiting consideration:

- Most food processing facilities consume less than 1-2 billion Btu/day.

LBG gas can be considered in most of the applications cited above for the industry, but problems may be raised by two factors due to quality control requirements: 
- Sulfur content

- Particulate content

LBG gasifiers may not be able to achieve adequate utilization in the food industry, for two reasons:

- Plant energy consumption is typically below 1 billion Btu/day

- Energy demands show significant variations, both daily and seasonally.

(11) Although Textile Mills Are Not Likely to Be Feasible Targets for Single-User LBG or MBG, Applications of Gas From a Multiple-User MBG 'Plant Are Feasible

Medium-Btu gas itself can be feasibly applied in the textile industry to replace natural gas and other fuels. Major technically feasible applications could include:

$$
\begin{array}{ll}
\text { - } & \text { Dryers } \\
\text { - Boilers. }
\end{array}
$$

However, the textile industry's consideration of MBG is generally limited to sharing in the output of a multiple-user facility, due largely to textile mill energy consumption factors:

Only the very largest textile mills consume as much:as 8 billion Btu/day, at the low end of the range of feasibly-sized MBG facilities

- Mill operations are not generally of a continuous process nature through the year.

Applications of LBG in drying are feasible only if the gas were particularly clean, since textile products may trap sulfur, particulates and other impurities in the gas stream. Boiler applications of LBG are technically feasible, although they may not be economically attractive. 
5. THE FEASIBLE MARKET FOR LOW- AND MEDIUM-BTU GASIFICATION CONSISTS OF THOUSANDS OF INDUSTRIAL PLANTS NATIONWIDE

Based on the preceding industry-by-industry and energy applications analyses, and relying on available data sources, the maximum feasible industrial market for lower energy coal gasification can be estimated for each of the three major system configurations under study.

(1) Low-Btu Gasification Is Technically Feasible in At Least 3500 Industrial Plants, in Most Major. Energy-Consuming Industries

Analysis of industrial energy use requirements and discussions with industries indicate that low-Btu gas can be used in most energy-consuming applications. Direct thermal applications can utilize LBG, with equipment adjustments generally necessary in retrofit applications, in most processes except those where flame temperatures in excess of $3000^{\circ} \mathrm{F}$ are required:

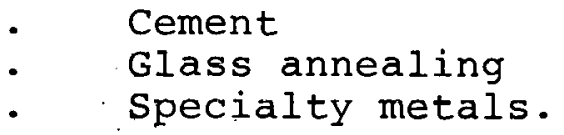

Boilers can utilize fuels of widely varying heat contents, including LBG, although burner adjustments may be necessary and derating is possible in retrofit applịcations.

Power generation applications can utilize LBG, although turbines must be designed to handle higher combustion volumes. The Dow Chemical experience in Plaquemine, Louisiana, may bear out the feasibility of applying LBG.

Feedstock applications of LBG are not generally likely, due to two factors:

- High inert content

- Low $\mathrm{H}_{2} / \mathrm{CO}$ content.

Few major energy-consuming industries are entirely precluded from feasibly applying low-Btu gasification. of 12 major industries investigated, only 3 evidence any significant limitations on the use of LBG for fuel purposes: 
- Cement

- Some fabricated metal products

- Food.

Currently operational LBG gasifiers in the U.S. indicate that LBG can be used in a number of industries, including:

- Cement (Iime calcining)

- Brick

- Metal fabrication (munitions manufacturing).

The number of plants with daily energy requirements large enough to ensure adequate gasifier utiliration is estimated to exceed 3500 :

- The Department of Energy has identified, as shown in Exhibit $\mathrm{V}-10,3500$ major fuel-burning installations nationally, including over 6000 . individual units with fuel-burning capacities exceeding 2.4 billion Btu/day, well above capacity minimums for LBG.

Assuming installation of a gasifier in each of these 3500 plants, the total fuels displaced annually could exceed 1.3 Quads, as shown previously in Exhibit $V-I$, with the following assumptions:

- 70 percent load factor

- LBG capacity per gasifier: 1.3 billion Btu/day.

(2) Single-User Medium-Btu Gasification Is Technically Feasible in More Than 550 Industrial Plants, But only in Selected Industries

Medium-Btu gas can be utilized in all major fueluging applications.

- Process heat applications can use MBG in all major fossil fuel-fired operations.

- Boilers can utilize MBG with modest adjustment, if any, and can even achieve higher efficiencies than natural gas in boilers designed or retrofitted to accommodate MBG. 


$$
\text { EXHIBIT } V-10
$$

Major Fuel-Burning Installations

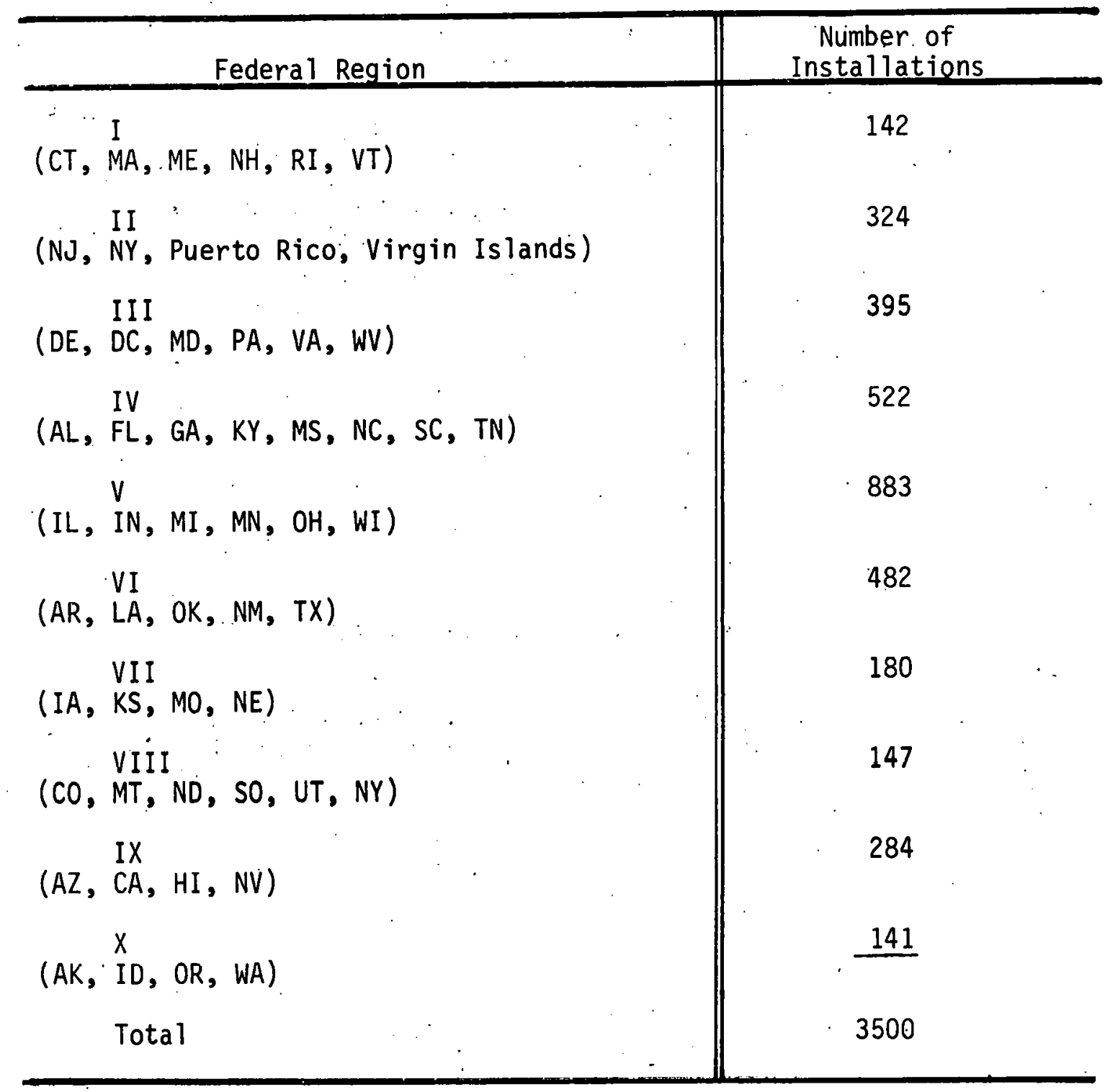

Source: M.F.B.I.: Complete Printout of FEA C-602-5-0, :Federal Energy Administration, Office of Data Service, February 14, 1977. 
- Power generation appiications are feasible and are being explored by several industries.

- Feedstock applications can use MBG as a substitute for natural gas and for some chemicals may find MBG a superior feedstock.

Medium-Btu gasification systems can achieve adequate utilization in more than 550 plants nationwide.

- As shown in Exhibit V-11; 558 industrial establishments consume more than 7.4 billion Btu/day in fossil fuels, slightly below the minimum feasible plant size for a sole-user MBG plant.

- The minimum feasible plant size criterion for economically scaled MBG facilities generally iimits the applicability of singleuser MBG plants to certain major industries:

- Chemicals

- Primary metals

- Petroleum

- Paper (larger milis only)

- Cement (larger plants only).

As shown previously in Exhibit $V-1$, the potential displacement of 550 plants' fossil fuel use with MBG could total more than 1.6 Quads per year, with the following assumptions:

$$
\begin{aligned}
& \text { - } \quad \text { MBG plant operating ratio of } 80 \text { percent } \\
& \text { Plant MBG capacity of } 10 \text { billion Btu/day. }
\end{aligned}
$$

(3) The Feasible Market for Multi-Plant MBG Facilities Exceeds 300 Gasification Plants, Potentially

Serving Thousands of Industrial Users

Medium-Btu gas itself can feasibly be applied, as shown above, in all major fuel-consuming applications:

- Process heat

- Boilers

- Power generation

- Feedstock.' 
EXHIBIT $V-11$

Number of Major Energy-Consuming Plants

\begin{tabular}{lc}
\hline Industry & $\begin{array}{c}\text { Number of } \\
\text { Establishments }\end{array}$ \\
\hline Ghemicals & 120 \\
Paper & 87 \\
Petroleum & 83 \\
Primary Iron and Steel & 61 \\
Cement & 43 \\
Primary Aluminum & 8 \\
Others & 156 \\
Total & 558 \\
\hline
\end{tabular}

* Number of plants with oil and gas consumption greater than 7.4 billion Btu/day.

Source: Low-Btu Gas Industrial Application Analysis; Systems Consultants, Inc., 1978. 
More than 300 medium-Btu gasification facilities are feasible in the multiple-user configuration.

- The nation's 272 Standard Metropolitan Statistical Areas (SMSAs) are generally each large enough to support a feasibly sized MBG facility. Average SMSA industrial-purchased fuel consumption, according to, Census Bureau figures, exceeded 70 billion Btu/day.

- The 20 largest SMSAs consumed, on average, in excess of 470 billion Btu/day in fossil fuels for industrial use, as shown in Exhibit V-12, enough to support at least two major gasifiers in each area.

Assuming installation of a feasibly sized MBG facility in 300 multi-plant systems nationally, more than. 2.9 Quads per year of fossil fuel could be displaced by MBG, as shown previously in Exhibit V-I, with the following assumptions:

- MBG plant load factor of 90 percent

- MBG plant output of 30 billion Btu/day.

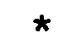

This chapter has presented a detailed assessment of the technically feasible market opportunity for LBG and MBG gasifiers. Although industry-by-industry generalizations must be qualified in light of significant technical factors that can only be examined on a plant-by-plant basis, this chapter has initially'identified these industries which can reasonably even begin to consider gasification. The following chapters will take into account the necessary economic, decisionmaking and other factors that will be used to narrow this technically feasible market down to the expected nearterm market. The next chapter begins the focus on the expected 1985 market by identifying high potential regions. 
EXHIBIT $V-12$

Industrial Consumption of Purchased

Fuels: 20 Largest Metrcpolitan Areas*

(1976)

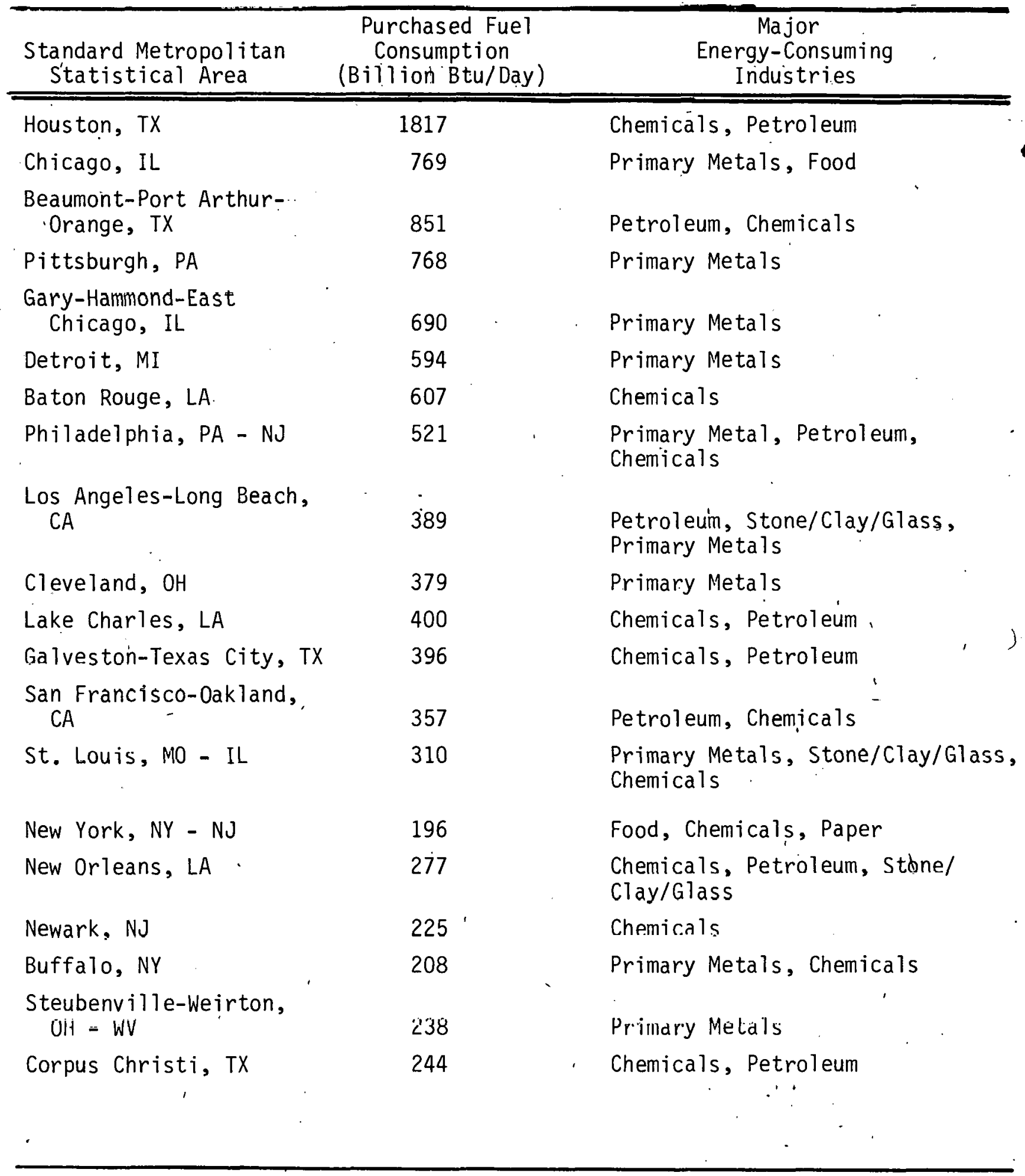

* SMSAs ranked by largest consumption of purchased fuels and electric energy.

SOURCE: Annual Survey of Manufacturers, 1976, U.S. Department of Commerce, Bureau of the Census. 
VI. IDENTIFICATION OF HIGH POTENTIAL REGIONS FOR COAL GASIFICATION 


\section{IDENTIFICATION OF HIGH POTENTIAL REGIONS FOR COAL GASIFICATION}

In order to identify potentially attractive areas for coal gasification, an initial geographical analysis was conducted. The purpose of this analysis, presented in this chapter, was to target the regions for selecting industries to be interviewed as potential coal gasification customers. Several regional factors were considered to have a significant effect upon the likelihood of attractiveness to coal gasification:

- Oil/coal price relationship. Areas with relatively high oil prices are likely regions for coal gasification. The ratio of oil to coal price, on a $\$ /$ million Btu basis, can be used to identify these areas with a high relative economic attractiveness of gasification, since coal costs account for 40 to 50 percent of the costs of gas from coal.

Fuel supply problems. Areas recently affected by shortages of natural gas'and other fuels have industries that are sensitive to supply security issues, and are likely candidates for coal gasification.

- Special circumstances. Areas with special environmental, political, or other regulatory problems are also considered potentially attractive.

1. BASED ON 1985 PROJECTED COAL AND FUEL OIL PRICES, SEVERAL REGTONS ARE MOST ECONOMICALLY ATTRACTIVE CANDIDATES FOR COAL GASIFICATION

(1) Attractive Regions for 1985 Early Adopters Are Identified on the Basis of Current Actual Coal and Fuel Oil prices

The analysis compares coal prices to the price of \#6 residual or \#2 distillate fuel oils, whichever is lower. Natural gas prices were not used as the standard of comparison with coal prices for two reasons: 
- Fuel oil is more costly than natural gas in most locations. For this reason, fuel oil users may represent the leading edge of the market for gasification.

- Natural gas prices are projected to increase to the level of fuel oil prices by 1985, as provided for in the Natural Gas Policy Act of 1978. Therefore, fuel oil prices today are a more representative indicator of the economic environment than natural gas prices.

Current actual 1979 prices modified by the following assumptions are utilized as the basis for Booz, Alien energy price forecasts for 1985:

- Coal prices are projected to remain nearly constant in real dollars to 1985

- Oil prices are projected to increase at 2 to 3 percent per year in real dollars to 1985, on average.

The resulting oil/coal price escalation factor is projected to be about 12.6 percent over the period 1979 to 1985 .

oil distributors in the major industrial areas (Exhibit VI-1) were contacted for price quotës at an energy usage rate of about 10,000 gallons/day--typical for a factory considering coal gasification. Platt's Oilgram Price Service, a daily oil price reporting service of McGraw-Hill, Inc., the oil Buyer's Guide, of Petroleum Publications, Inc., and the oil Daily were used to augment the dealer price information. Using these together, the oil prices were documented for the major terminals throughout the United states in January and February 1979. To estimate the price of oill at locations not near a terminal, a transportation charge was assessed using costs of transportation from estimates made by oil distributors for locations serviced.

Exhibit VI-2. shows the lesser price of a barrel of distillate \#2 or residual \#6 oil at each of the major terminals in the continental U.S. 
McGraw-Hill Inc. Continental oil Co. Texaco Heating Continental oil co. Exxon

Exxon

Exxon

Gulf oil co. Gulf Oil Co. Mobil Oil Co. Gulf Oil Co. Gulf Oil Co.
Washington, D.C.

Renshall, Minnesota Duluth, Minnesota

Houston, Texas

Denver, Colorado

Salt Lake City, Utah

San Francisco, California

(Walnut Creek)

Baltimore, Maryland

Philadelphia, Pennsylvania Chicago, Illinois

New Orleans, Louisiana

Detroit, Michigan 


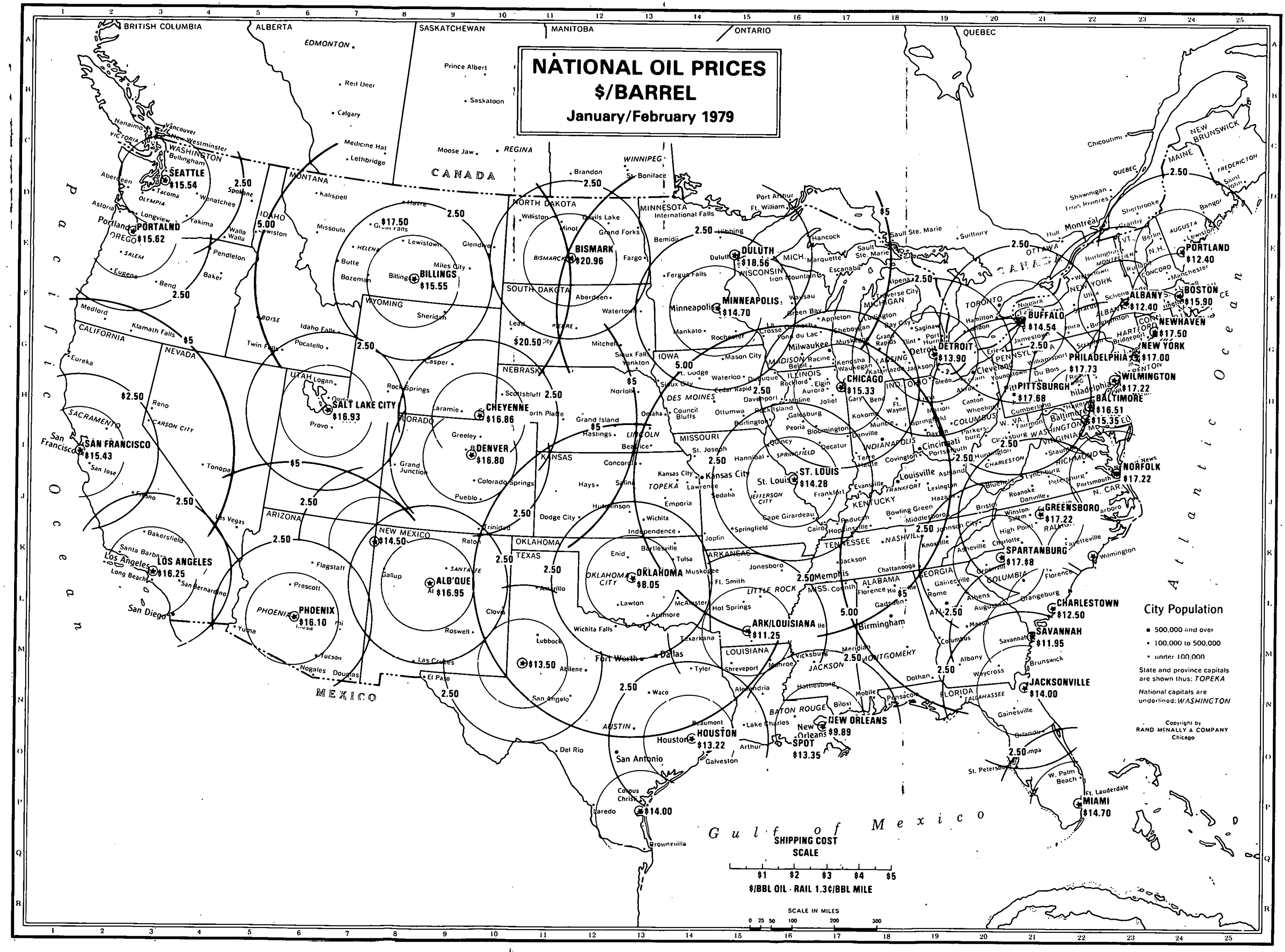


(2) Coal Prices for 1985 Were Estimated From Actual Coal Broker Quotes of Mine and Transportation Costs

Coal brokers throughout the United States were interviewed as to the mine-mouth prices and transportation costs that were current for January and February 1979. Augmenting these sources for coal prices and transportation costs was Coal Week, a McGraw-Hill, Inc. publication. The price sources are shown in Exhibit VI-3.

Exhibit VI-4 shows the national coal prices and the: heating content of the coals being quoted for January and February 1979, at the major mining areas. Using these data and the transportation cost estimates shown on the map for west, central and eastern areas, coal costs may be determined for all locations in the United States.

The U.S. mining region with the lowest price coal. in terms of energy content, is in Wyoming. There the mine-mouth coal. cost is about $\$ 9.64 /$ ton, equivalent to $\$ 0.46 / \mathrm{MMBtu}$, including the state severance and reclamation taxes. North Dakota has the next less expensive coal, lignite, at $\$ 7.50 /$ ton for an energy cost of $\$ 0.54$. The eastern coals are more expensive. Ohio surface mined coal and coal from the underground mines of West Virginia cost about the same at $\$ 26 /$ ton, $\$ 1.08$. Highest priced are the Pennsylvania anthracite coals at about $\$ 45.00, \$ 1.61 / \mathrm{MMBtu}$.

Transportation, which may account for a large share of coal costs in most parts of the country, is estimated based upon distance from the mine using actual. rates established by the Federal Interstate Commerce Commission (ICC) with additional charges allowed for transfer among carriers.

In the west and central United states, the rail costs and number of different carriers are less than in the eastern areas. Therefore, a method of estimating transportation charges was devised, which estabilished different mileage. rates for the three parts of the country. These rates are as follows:

Estimated Coal Rail Transportation Rate: I0-Car Train

West

Central

East
$2.5 \% /$ ton-mile

$3.6 \% /$ ton-mile

$5.0 \% /$ ton-mile 
Coal Price Interviews

Con Coal Co., Knoxville Tennessee Peabody Coal Co., Denver, Colorado Bengus Coal, Orlando, Florida Consolidation Coal Co., Pittsburgh, Pennsylvania Coastal States Coal, Houston, Texas Peabody Coal Co., Minneapolis, Minnesota Pickands Mather \& Co., Chicago, Illinois Peabody Coal Co.', St. Louis, Missouri North American Coal Corp., Cleveland, Ohio North American Coal Corp., Bismark, North Dakota univ. uf Milllesola, Duluth, Minnccota Consolidation Coal Co., New York City, New York Lehigh Valley Coal Sales Co., Philadelphia, Pennsylvania Lehigh Valley Coal Sales Co., West Pittston, Pennsylvania Coal Week, Mc-Graw Hill Inc., Washington, D.C. 


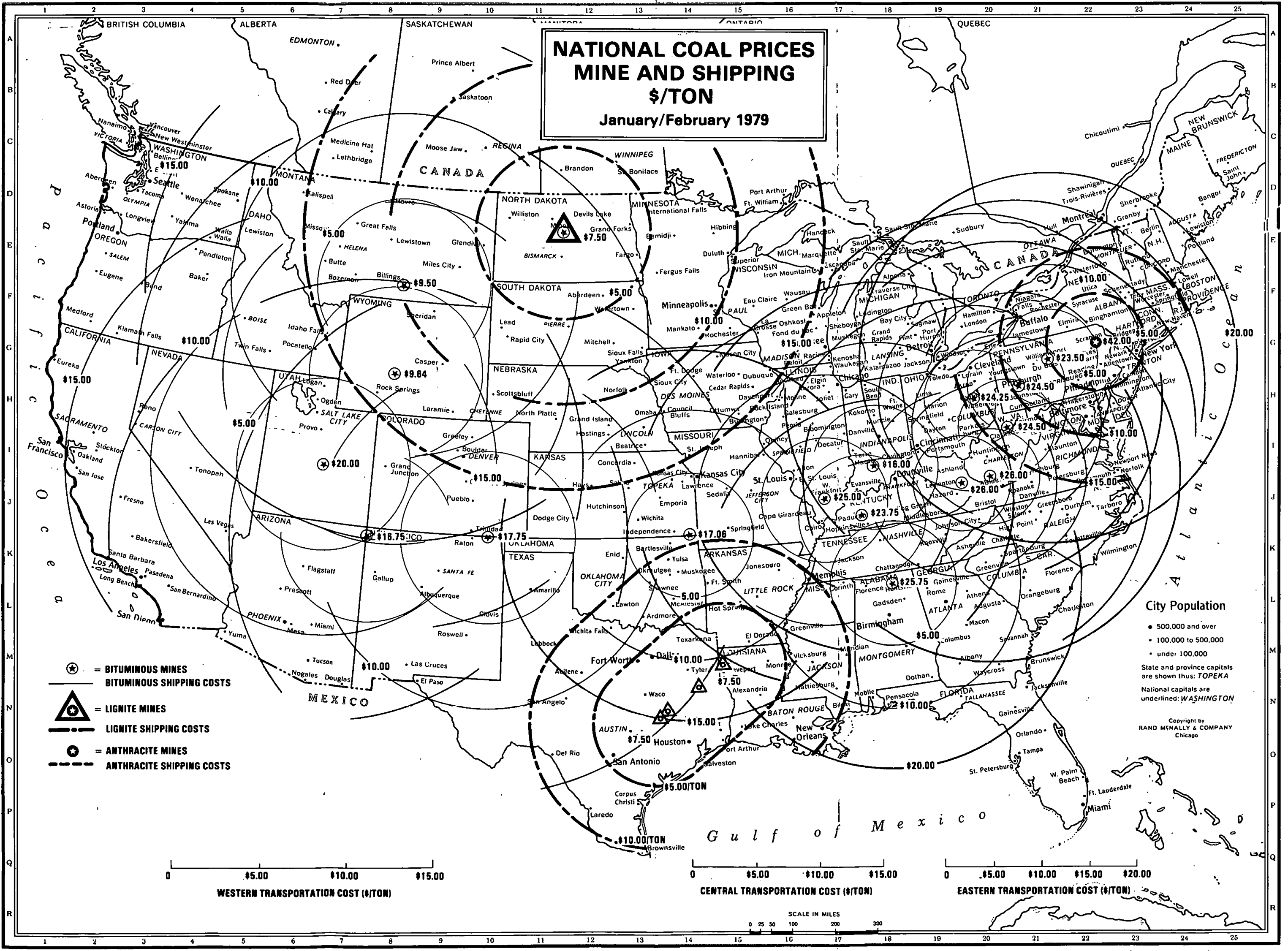


(3) Coal Gasification Has the Potential of Being Attractive in Those Areas in the U.S. Where coal Prices Are High Relative to Oil prices

The next step to identify those areas throughout the U.S. with the larger oil to coal price differentials, was to project a $30 \times 12$ grid on a U.S. map. Oil and coal prices were determined at over 200 grid intersections using the data from the National oil price Map, Exhibit VI-2 and the National Coal Price Map, Exhibit VI-4. The relative regional economic attractiveness of coal energy to oil energy in 1979 dollars was then calculated from these prices. Areas with a larger ratio of oil price/Btu to coal price/Btu are those areas with the larger price divergency between oil and coal. These are the areas most likely to find coal gasification attractive. There, energy price conditions exist which more readily allow the extra coal gasification costs to be absorbed before the resulting industrial coal gas becomes more expensive than the competing oil or natural gas. The following equation was used to determine the attractiveness ratio (RA)

$$
R A=\frac{\text { Oil Price/Btu }}{\text { Coal Price/Btu }}
$$

To each of the attractiveness ratios an oil/coal price escalation. factor of 12.6 percent was added to show the expected pricing situation in 1985.

The result's are shown on Exhibit VI-5, 1985 Oil Price/Coal Price Ratio Map where ratios of equal value are connected. The enclosed areas delineate boundaries at which there is the same relative price attractiveness.

Five areas stand out in Exhibit VI-5 as having the most favorable coal price advantages. These are located in:

- Texas and Louisiana
- Nyoming, Colorado and Utah
- North Dakota
- Tennessee and Kentucky
Pennsylvania, Ohio and Indiana.


EXHIBIT VI-5

- Economically Attractive Regions for LBG and MBG

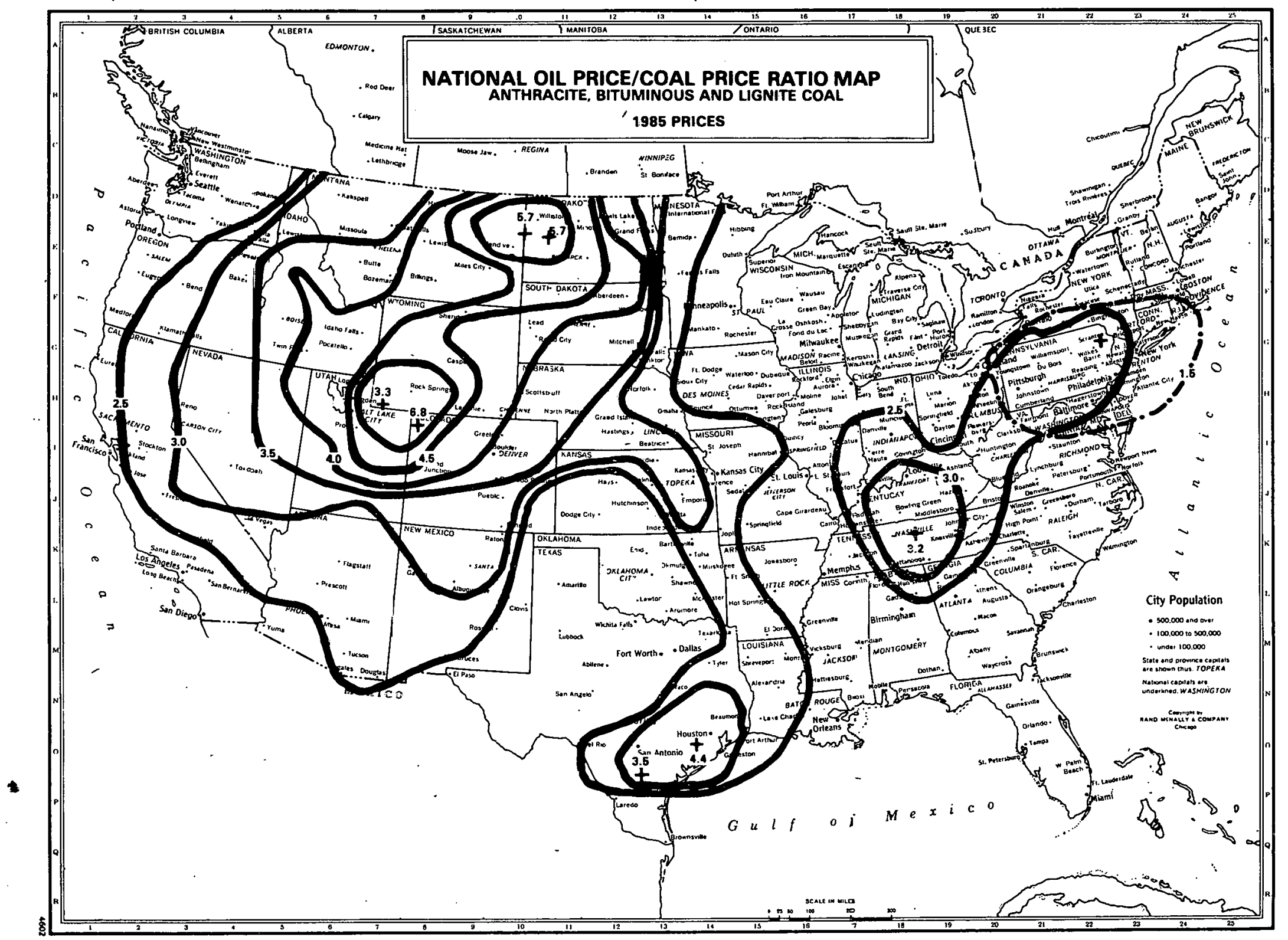


This straightforward economic analysis indicates areas of relative economic attractiveness of coal to. oil and identifies regions where coal gasification is most likely to be attractive. The higher the oil/coal price ratio, the more likely coal gasification will be economically attractive within that area in 1985.

The value of the ratio where gasification is no longer attractive. is more difficult to determine, For example, in many areas of the country, coal costs would constitute about 40 percent of the total cost of the produced coal gas. The remainder of the costs would be composed of the capital cost of the gasifier and support equipment, labor, utilities and return on investment requirements. The 40 percent figure would indicate, then, that the breakpoint of attractiveness would be at about the 2.5 ratio. One might assume that all areas within this area would be attractive. This is not necessarily true, because whereas the capital cost, labor, etc. of the 60 percent contribution to gas cost is relatively fixed, coal prices:and the degree of gas clean-up (i.e., de-sulfuring) is variable. Western coal is relatively lower priced and lower in sulfur content than eastern coals, and thus may be attractive beyond the 2.5 ratio.

To determine where coal gas (not just coal) is economically competitive with oil and natural gas on a $\$ / m i l i$ ion Btu basis, a site-specific analysis must be done. For each potential user, the analysis would include:

- Optimum gasifier configuration
Gas clean-up requirements
Coal type
- Coal handling requirements
- Output gas requirements.
- Process retrofit costs.

2. ADDITIONAL ATTRACTIVE REGIONS ARE IDENTIFIED ON THE BASIS OF HISTORICAL FUEL SUPPLY PROBLEMS

This section identifies the states which, because of a history of supply problems associated with natural gas and alternate fuels, are high potential regions for coal gasification. Four conditions that would contribute to increasing the desirability of low- and medium-Btu gas use in industry àre: 
- Industrial curtailments of natural gas

- Shortages of alternate fuels or the inability to use them in certain processes

- Employment problems related to gas shortages

- Special problems adding to supply insecurity. (e.g., increased residential demand causing further industrial curtailments, frozen rivers, etc.)

Data collection focused on reports from industry and government concerning the problems experienced from actual fuel curtailments in the United States for the years 19751978. Information and sources which were used in this analysis are referenced in Appendix D. In addition, interviews were conducted with members of the public and private sector who were involved with or affected by gas curtailments. Appendix D also incorporates the evidence collected.

As indicated in Exhibit VI-6, the Southeast was most severely impacted by industrial curtailments of natural gas over the 1975-1978 period. The states of North Dakota, Louisiana, Illinois, and Ohio were also severely affected. Seven additional states were found to have less severe, but nevertheless repeated industrial gas shortages over the same period. Several states, stretching from Pennsylvania to California, have had shortages of varying severity.

- Alternate fuel availability problems during the 1977-1978 heating season were dispersed, as shown in Exhibit VI-7, leaving many natural gas users unable to meet their energy needs. Large concentrations of shortages occurred along the Middle Atlantic states and also stretched into the midwest, affecting Missouri, Kansas, South Dakota, and Wyoming.

- Exhibit VI-8 illustrates the employment impact of gas shortages which occurred over the 1976-1977 winter season., Again, the Middle Atlantic states were highly affected, with problems also apparent in Pennsylvania, Ohio, Indiana, Kentucky, and Illinois.

- Weather-related problems caused additional shortages of both gas and alternate fuels, through 
States with Industrial Sectors

fy Natural Gas Curtailments - 1975-78

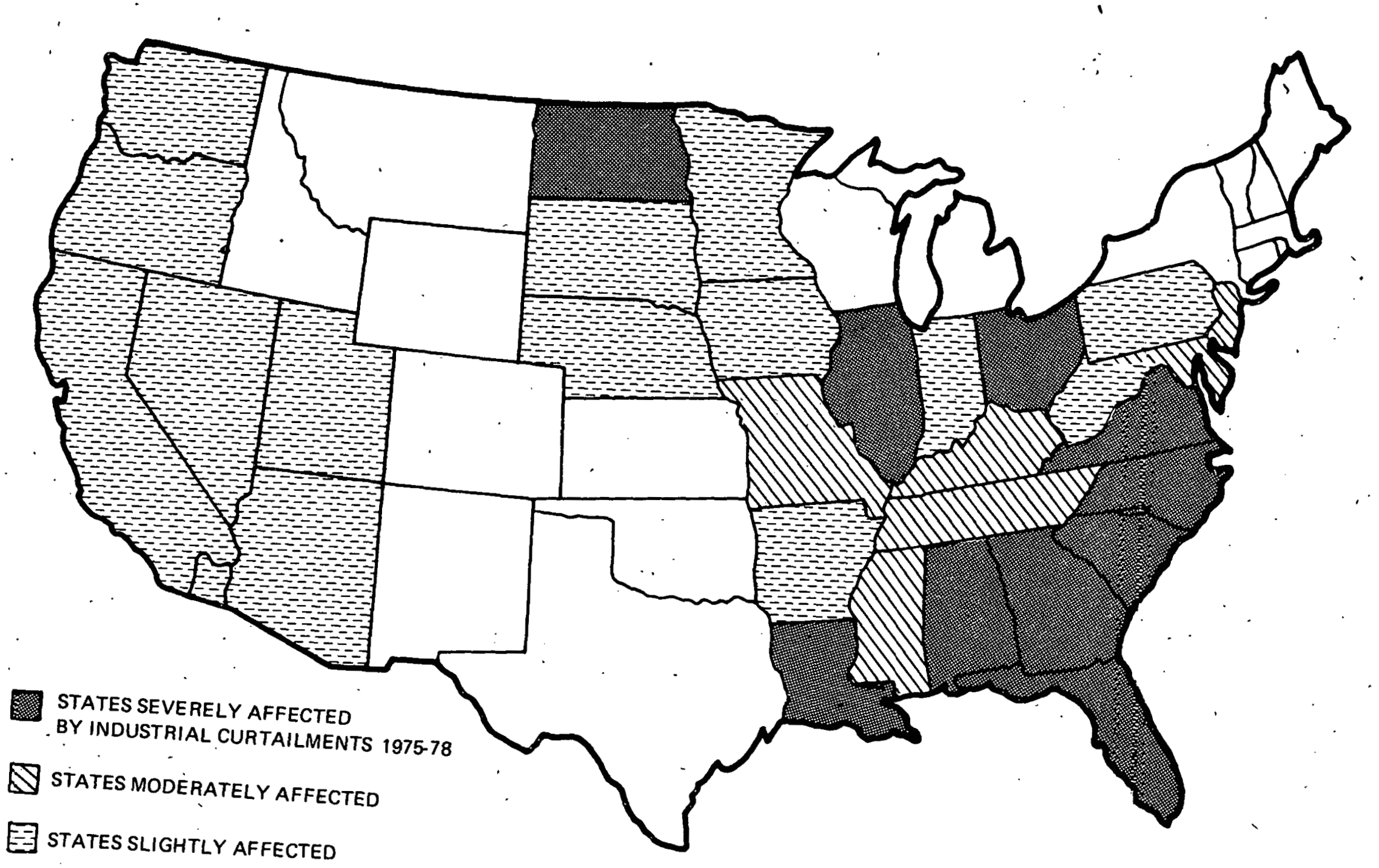


EXHIBIT VI-7

States With Alternate Fuel Supply Problems

$1977-78$

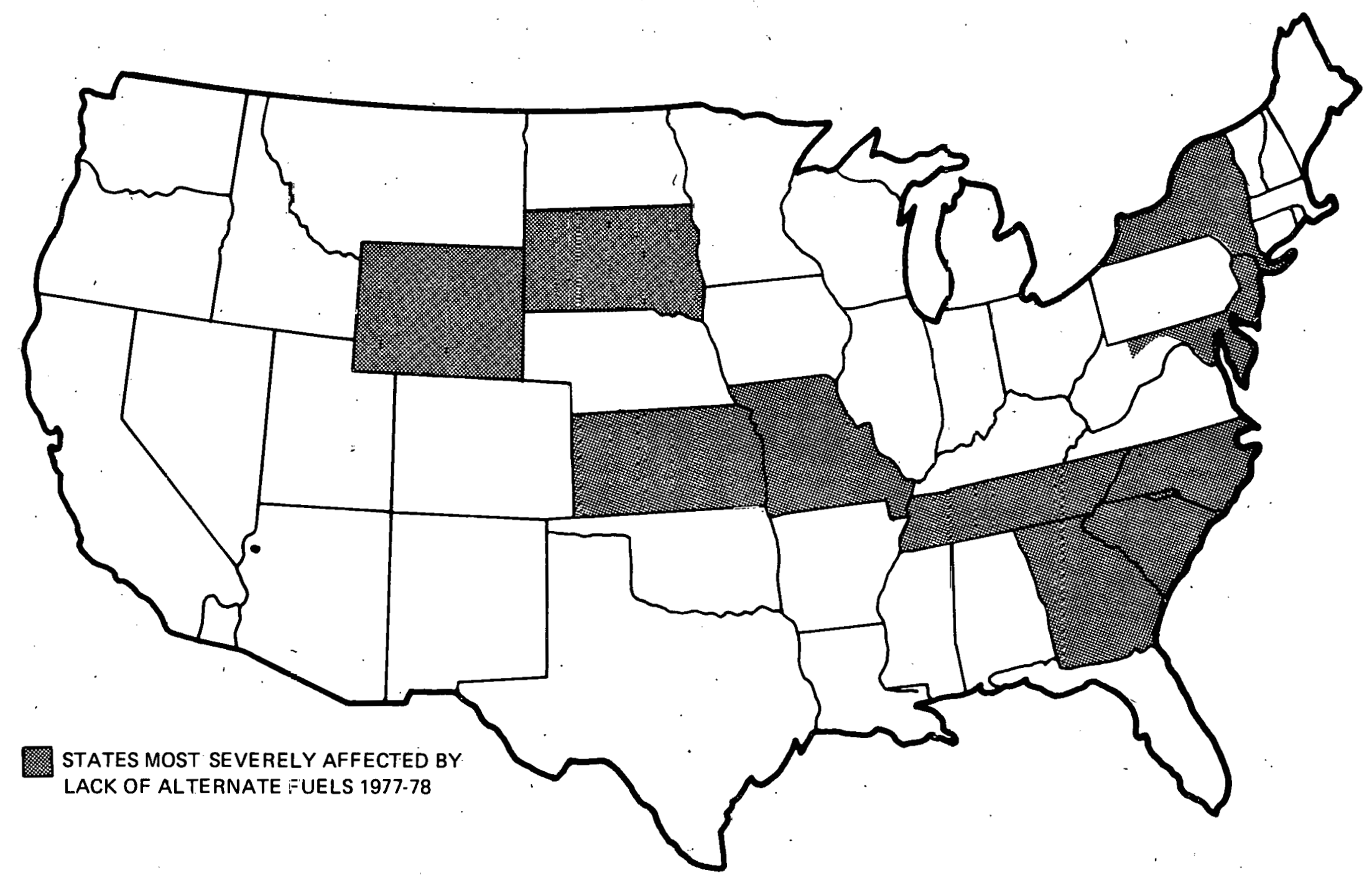


EXHIBIT VI-8

States With Employment Problems Related to Gas Shortages - 1976-77

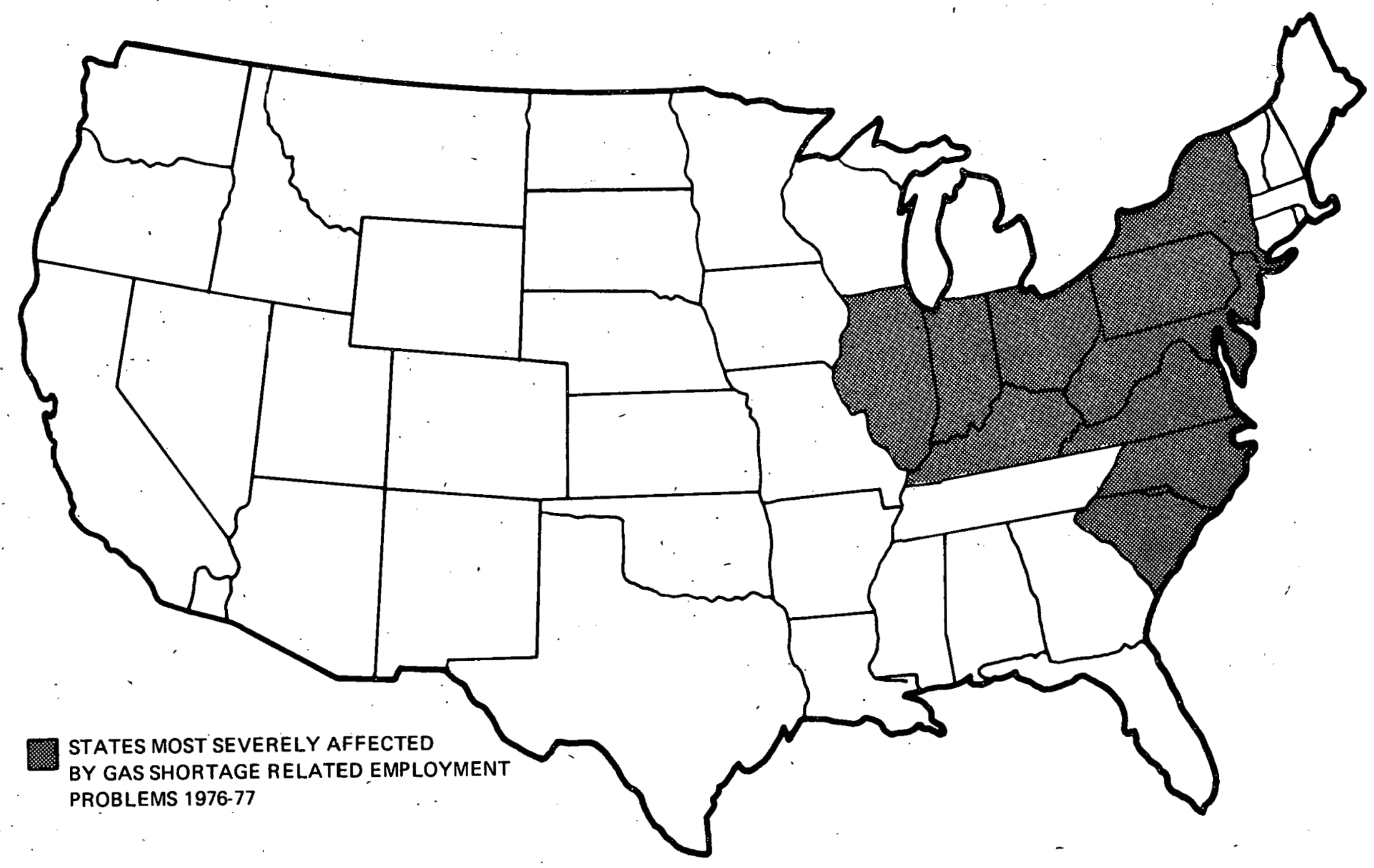


increased heating demand and transportation difficulties. Impacts were severe in four states: New York, Pennsylvania, Ohio, and Kentucky.

Analysis of the four supply security impact maps led to an overall state ranking (Exhibit VI-9):

- The states most severely affected were those with overlapping problems, found mainly in the Middle Atlantic area. Other severely affected states inclüded Ohio, Kentucky, Teńnessee, and Missouri.

- Several additional states were moderately affected overall, due mostly to consistently severe industrial curtailments. These states covered the Gulf Coast, some of the midwest, and New York, Pennsylvania, and Virginia.

- States which had been identified as having some variable fuel supply problems were grouped into the third tier. These cover a broad area of the country.

3. THE TARGET STATES FOR COAL GASIFICATION COMMERCIALIZATION ARE SELECTED ON THE BASIS OF ECONOMIC ATTRACTIVENESS, A HISTORY OF SUPPLY PROBLEMS AND POPULATION GROWTH, COUPLED WITH STRINGENT ENVIRONMENTAL REQUIREMENTS

The primary regions in which the early adopters of coal gasification can be expected are those states which show both a high potential for economic viability and uncertain natural gas supply. Overlaying the economically attractive areas shown on Exhibit VI-5, Oil Price/Coal Price Ratio Map, on the states with fuel supply problems identifies the candidate states for early commercialization of coal gasification.

Experience of the project team with California industry, utilities, and government led to judgmental inclusion of the state as a primary high potential area. Energy users in california have few alternatives to oil and natural gas due to stringent environmental regulations. New construction of industrial plants in the state may require alternative energy solutions, such as coal gasification.

The results of these selections, shown in Exhibit VI-10, are as follows: 
EXHIBIT VI-10

Target States for Coal Gasification Commercialization

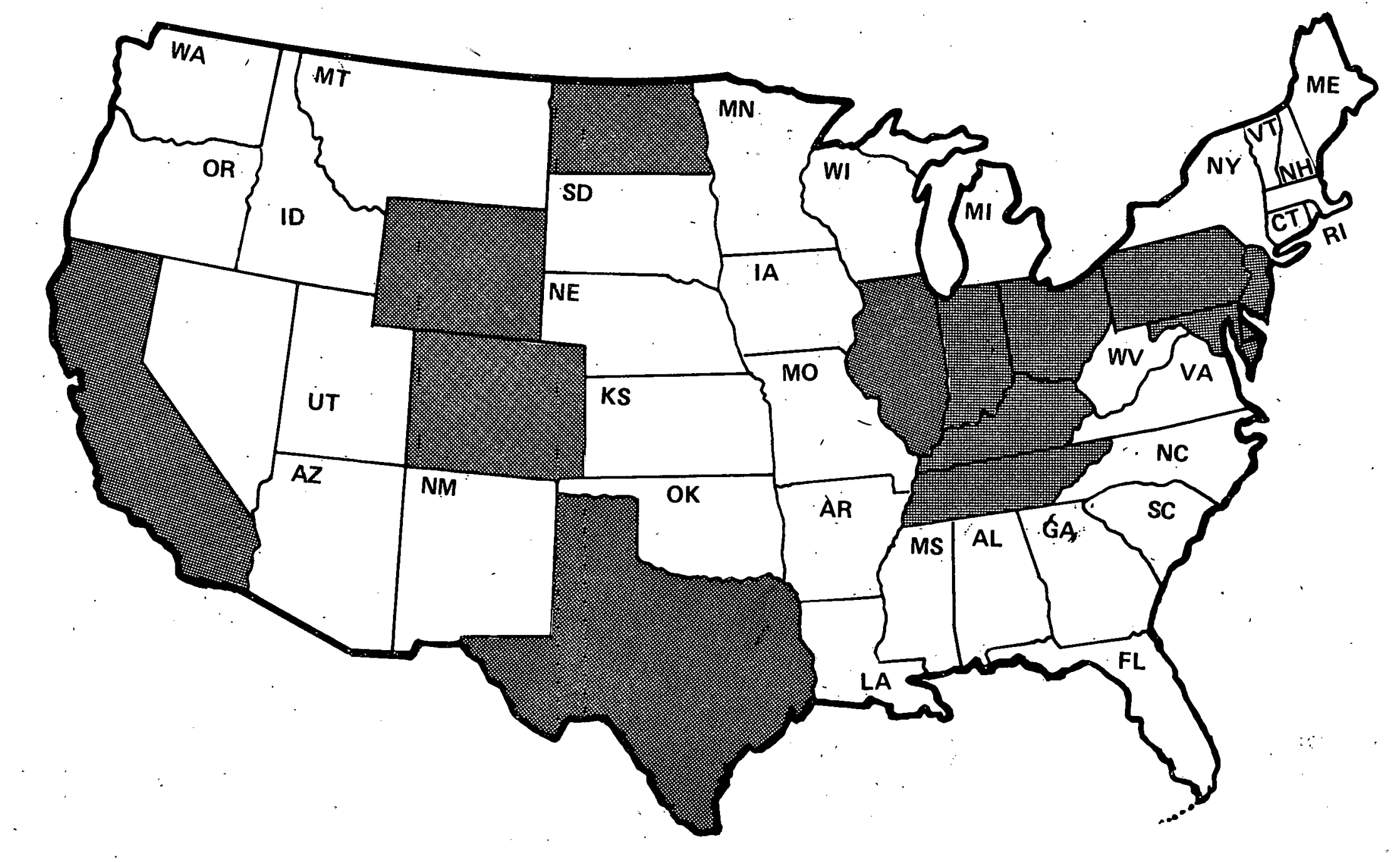


EXHIBIT VI-9

Overall Impact of Gas Shortages

1975-78

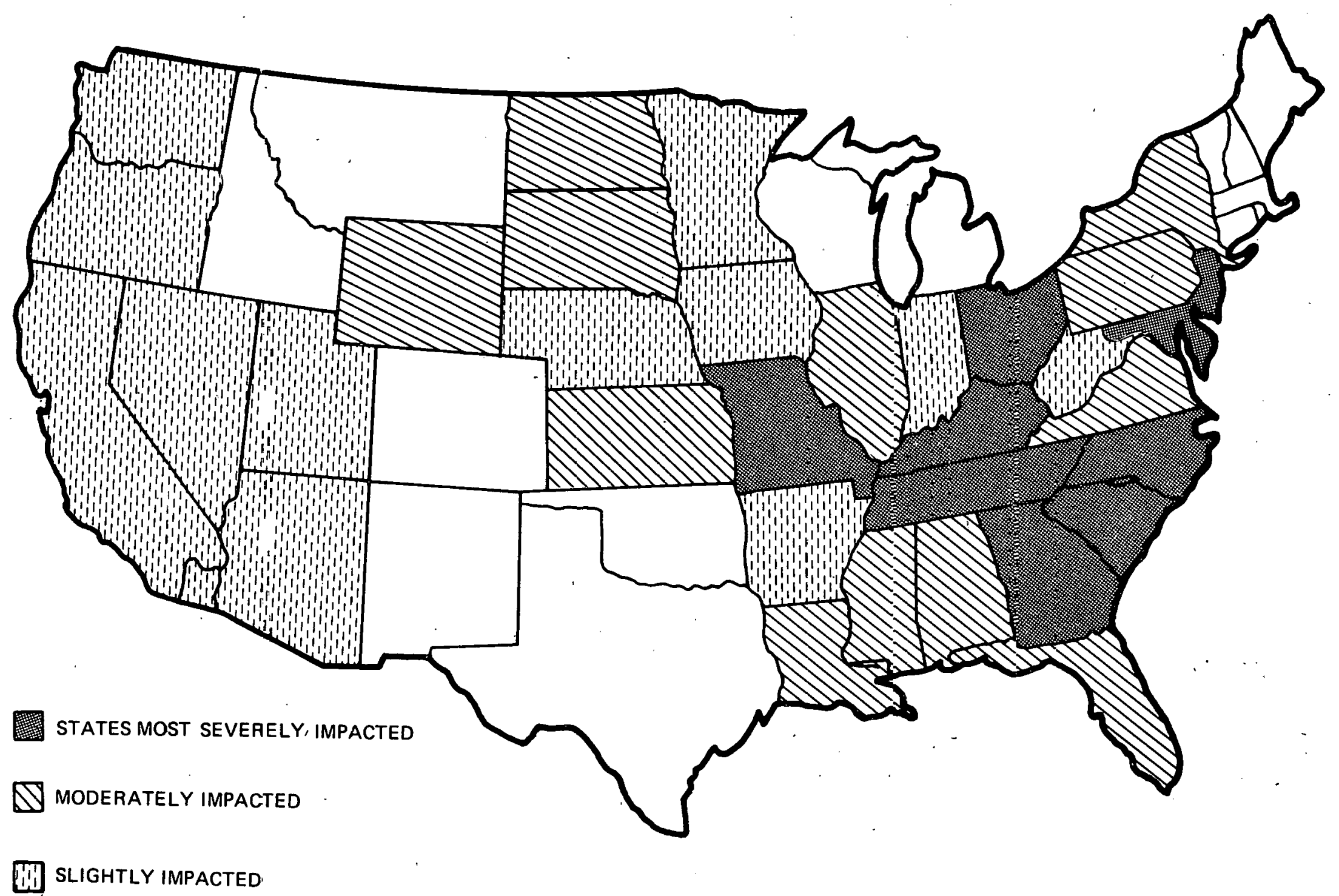


TARGET STATES FOR COAL GASIFICATION COMMERCIALIZATION

California

Colorado

Delaware

Illinois

Indiana

Kentucky

Maryland
New Jersey

North Dakota

Ohio

Pennsylvania

Tennessee

Texas

Wyoming

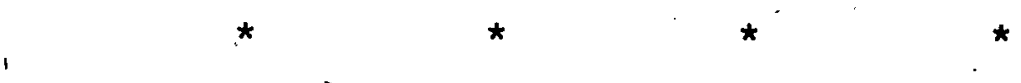

This chapter has presented an analysis identifying the regions in which early adopters of $\mathrm{LBG}$ and MBG are most likely to be found. Based on this analysis, which preceded industry interviews, in-depth discussions were conducted principally with companies that operate plants in the nine primary target states. The next chapter presents the most important element of those interviews, an industry-by-industry evaluation of the near-term market for LBG and MBG. 
VII. ESTIMATE OF THE NEAR-TERM MARKET FOR LOWAND MEDIUM-BTU GASIFICATION 
VII. ' $\frac{\text { ESTIMATE OF THE NEAR-TERM MARKET FOR LUW- }}{\text { AND MEDIUM-BTU GASIFICATION }}$

The expected near-term industrial market for low-'and medium-Btu coal gasification includes potential industrial plants which are likely to have such a facility in operation or under construction by 1985. This chapter's market assessment will identify the industries and applications which are the best candidates for near-term adoption of low- and medium-Btu coal gasification systems in the three major equipment configurations under study.

- Low-Btu gasification, single-user plant

- Medium-Btu gasification, single-user plant

- Medium-Btu gasification, multiple-user plant.

To identify the likeliest early adopters, the analysis developed and applied three common sets of early adoption criteria--one for each gasifier configuration--to each. industry under consideration. Based on these findings and on interview findings as to industrial investment plans, the market assessment estimates the expected market for 1985 at:

- $10^{\circ}$ to 20 low-Btu gasifiers
2 to 3 medium-Btu, single-user gasifiers
No medium-Btu, multiple-user gasifiers.

For each gasifier configuration, the analysis also addresses the major barriers to further penetration of the industrial market in the near-term.

1. THE 1985 EXPECTED MARKET FOR LOW-BTU GAS IS FORECAST TO CONSIST OF 10 TO 20 NEW LBG PLANTS, INSTALLED MOST LIKELY IN THE STEEL, BRICK AND 4 OTHER SELECTED INDUSTRIES

Analysis of the near-term market for low-Btu gasifiers resulted in an estimate of 10 to 20 newly installed units by 1985. Applications will be primarily in the steel and brick industries. Four other industries, as shown in Exhibit VII-1, with moderate potential are also considered candidates for installed gasification units; 
EXHIBIT VII-1

Early Potential Adopters of On-Site 、 Low-Btu Gasification

High Attractiveness:
- Steel
3-5 Gásifiers
- Brick
3-5 Gasifiers
Moderate Attractiveness:
3-5 Gasifiers

- Aluminum and Other Non-Ferrous Metals

- Refractories

- Ceramics/Tile

- Chemicals

Low Attractiveness :

0-3 Gasifiers

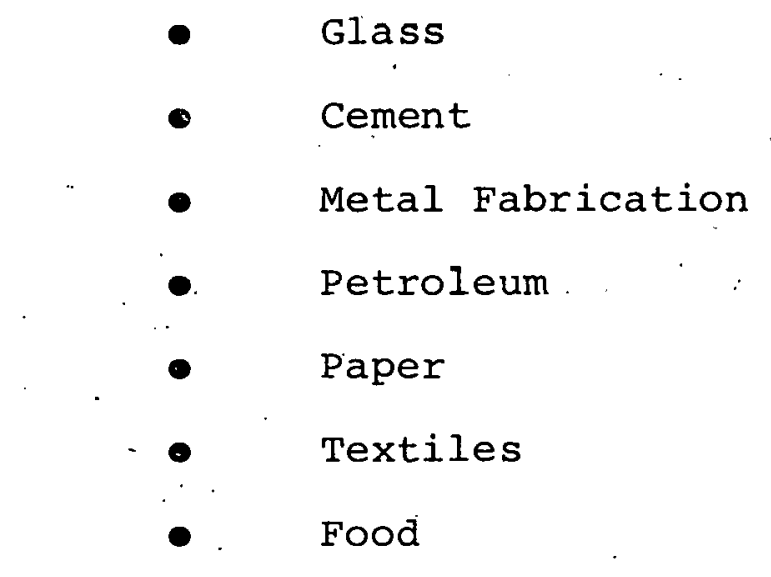

Electric Generation

1-2 Gasifiers

- LBG Forecast 
(1) The Low-Btu Gas Early Adopter Screening Focused on Ten Factors

From industry interviews with manufacturers of gasification systems, existing domestic users, and potential LBG users, and reviews of existing literature and studies in coal gasification, ten major factors were commonly stated to have an impact on adoption of low-Btu gas by industry for process/steam use:

- Flame characteristics/chemical composition. This, as examined in chapter $V$, determines the technical feasibility of using LBG.

- Large capacity/high load factor. A plant must utilize at least about 0.5 billion Btu/ day of gas with a steady, high demand (on the order of 80-90 percent) to economically utilize a single LBG gasifier.

Low retrofit cost. Ease of retrofitting existing processes will enhance the economic and technical attractiveness of LBG.

- Need for a clean gas. This is a screen to determine the applicability of the three common types of. LBG:

$$
\begin{aligned}
& \text { - Hot raw gas (containing tars, oils, } \\
& \text { particulates, and sulfur) }
\end{aligned}
$$

- Hot detarred gas (tars and particulates removed)

- Cold clean gas (all impurities removed).

- Natural gas supply sensitivity. High dependenceas a percent of energy consumption-on natural gas and/or a history of curtailments will make users sensitive to supply security.

Cost of oil and gas as a percent of sales. A high percentage reflects an incentive to shift to a more economically attractive fuel to reduce product costs.

Coal use. This determines the existence of coal handling equipment and familiarity with coal use and aisposal. 
- Captive coal supplies. Company-owned reserves can lead to an economic advantage in producing low-cost LBG.

- Location in high potential areas. Location in the nine states identified in the chapter VI regional analysis indicates a high potential for economic and secure low-Btu gas production, relative to expensive oil and curtailed natural gas.

- Familiarity with gasification. A history of proven industrial application and involvement in gasification projects and studies indicates a higher poténtial for early adoption of LBG due to interest in LBG and removal of technical barriers.

Thirteen energy intensive industry groups were screened against these factors as shown in Exhibit VII-2 to determine the high-potential early adoptors. A detailed: analysis chart is provided in Exhlbit VII-3 which shows the relative attractiveness of the industries.

The steel and Brick Industries Show Potentially the Most Attractive Conditions for LBG Use. Three to Five LBG Gasifiprs Are Forecast to Be in Operation in Each Indistry By 1985

Conclusions from the screening analysis indicate that steel and brick applications are the most attractive. These are discussed in the following paragraphs:

- Steel. With an excellent terhnical. fit with hot detarred and cold clean LBG, there are a large number of feasible applications in the steel industry as outlined in Exhibit VII-3. Captive coal for use in coking, concentrations in economically attractive regions, and oil and gas as a moderate percent of sales enhance the economic attractiveness of LBG. The possible use of anthracite coal would eliminate the use of clean up equipment, further adding to the attractiveness. The domestic history of substantial LBG use in this industry in the 1920's removes many of the technical questions associated with LBG use. The very good fit with LBG characteristics and 
EXHIBIT VII-2

Industry Screening Summary: Low-Btu Gasification

\begin{tabular}{|c|c|c|c|c|c|c|c|c|c|c|c|c|}
\hline \multirow{2}{*}{ INOUSTRY } & \multicolumn{2}{|c|}{$\begin{array}{l}\text { FEASIBILITYY } \\
\text { CRITERIA }\end{array}$} & \multicolumn{4}{|c|}{$\begin{array}{c}\text { BASIC } \\
\text { ATTRACTIVENESS }\end{array}$} & \multicolumn{5}{|c|}{ EARLY AOOPTER CHARACTERISTICS } & \multirow[b]{2}{*}{$\begin{array}{c}\text { EARLY } \\
\text { ADOPTERS } \\
\end{array}$} \\
\hline & $\begin{array}{r}\text { FLAME \& } \\
\text { CHEMICAL } \\
\end{array}$ & $\begin{array}{l}\text { CAPACITY \& } \\
\text { LOAD FACTOR }\end{array}$ & $\begin{array}{l}\text { EASE OF } \\
\text { RETRQFIT }\end{array}$ & HOT RAW & $\underbrace{\text { TYPE }}_{\text {COLO CLEAN }}$ & $\begin{array}{l}\text { SENSITIVE TO } \\
\text { GAS SUPPLY }\end{array}$ & $\begin{array}{l}\text { HIGH OIL AND } \\
\text { GAS COST }\end{array}$ & $\begin{array}{l}\text { CURRENT } \\
\text { COAL USER }\end{array}$ & $\begin{array}{c}\text { CAPTIVE } \\
\text { COAL SUPPLY }\end{array}$ & $\begin{array}{l}\text { HIGH POTENTIAL } \\
\text { LOCATIONS }\end{array}$ & $\begin{array}{c}\text { FAMILIARITY } \\
\text { WITH TECHNOLOGY } \\
\end{array}$ & \\
\hline F000 & e. & $\partial$ & $\ominus$ & 0 & - & $\ominus$ & 0 & $\ominus$ & 0 & 0 & $\ominus$ & 0 \\
\hline tEXTILES & $\bullet$ & $\ominus$ & $\ominus$ & 0 & - & $\dot{\bullet}$ & 0 & $\bullet$ & $\mathrm{O}$ & 0 & O & O \\
\hline PAPER & $\bullet$ & $\theta$ & $\theta$ & O & 0 & 0 & $\bullet$ & $\bullet$ & $\bullet$ & $\ominus$ & $\ominus$ & 0 \\
\hline CHEMICALS & $\ominus$ & $\bullet$ & O & $\bullet$ & 0 & $\ominus$ & $\bullet$ & $\bullet$ & $\theta$ & - & - & $\ominus$ \\
\hline PETROLEUM & - & $\bullet$ & $\bullet$ & $\bullet$ & $\ominus$ & 0. & 0 & $\ominus$ & $\bullet$ & - & O & 0 \\
\hline GLASS & $\ominus$ & - & $\theta$ & 0 & - & $\ominus$ & - & 0 & 0 & $\ominus$ & $\bullet$ & $\theta$ \\
\hline CEMENT & $\ominus$ & $\ominus$ & - & $\bullet$ & 0 & 0 & $\bullet$ & - & $\ominus$ & $\ominus$ & - & 0 \\
\hline BAICK & $\bullet$ & $\bullet$ & - & $\bullet$ & 0 & - & - & O & 0 & $\ominus$ & - & $\bullet$ \\
\hline CERAMICSTIILE & $\bullet$ & $\ominus$ & $\ominus$ & 0 & - & - & - & 0 & 0 & $\ominus$ & - & $\ominus$ \\
\hline REFRACTORIES & - & - & $\ominus$ & $\ominus$ & $\bullet$ & $\bullet$ & - & $\bullet$ & 0 & $\ominus$ & $\bullet$ & $\theta$ \\
\hline STEEL & $\bullet$ & - & $\bullet$ & $\ominus$ & - & $\ominus$ & $\theta$ & $\bullet$ & $\bullet$ & $\bullet$ & $\bullet$ & - \\
\hline $\begin{array}{l}\text { AL \& OTHER } \\
\text { NONFERAOUS }\end{array}$ & - & $\cdot \bullet$ & $\theta$ & $\ominus$ & - & $\theta$ & 0 & O & $\theta$ & $\ominus$ & $\bullet$ & $\ominus$ \\
\hline $\begin{array}{l}\text { METAL } \\
\text { FABRICATION }\end{array}$ & - & 0 & $\bullet$ & $\ominus$ & $\bullet$ & $\bullet$ & 0 & 0 & $\bullet$ & $\theta$ & $\bullet$ & 0 \\
\hline
\end{tabular}

KEY: - : INDUSTRY MEETS CRITERION

$O$ : INDUSTRY MEETS CAITERIDN IN PART
: INDUSTRY DOES NOT MEET CRITERION

SOURCE: BASED ON EXHIBIT VII-2 


\begin{tabular}{|c|c|c|c|c|c|c|}
\hline \multirow{2}{*}{ novistray } & \multicolumn{2}{|c|}{ 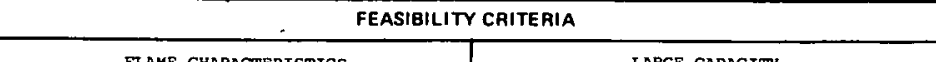 } & \multicolumn{4}{|c|}{ 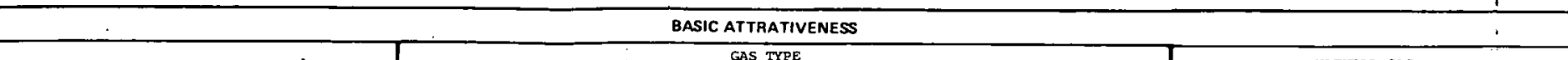 } \\
\hline & 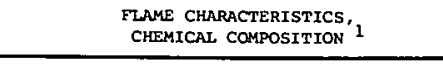 & 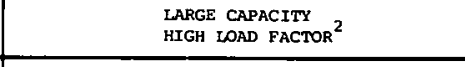 & 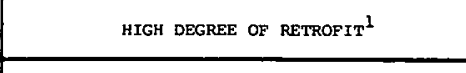 & Wox Rax & Oow CLLWN & 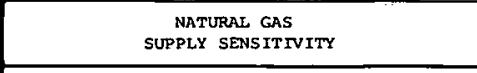 \\
\hline${ }^{5000}$ & 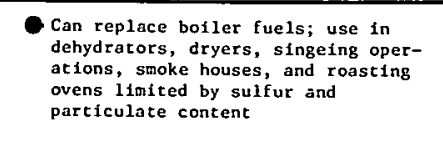 & 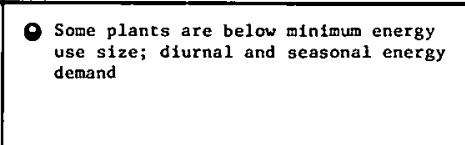 & 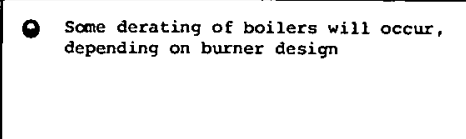 & O can be used in botlers only & 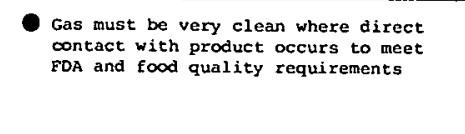 & 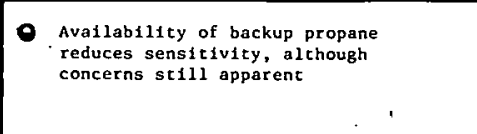 \\
\hline Textlues & 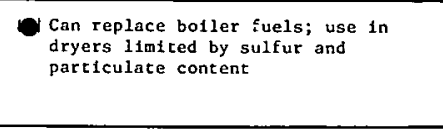 & 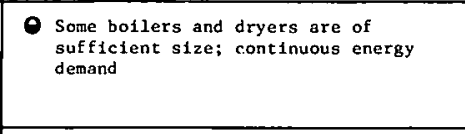 & 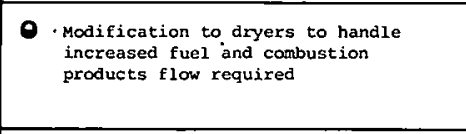 & 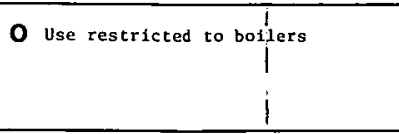 & 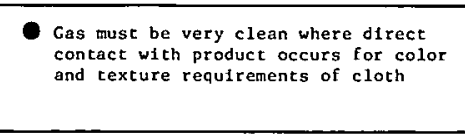 & 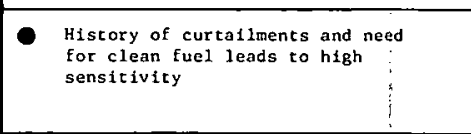 \\
\hline PAAFR & - Can Eeplace bollier fuelts & 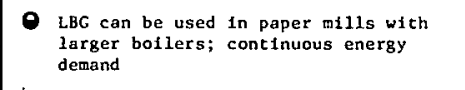 & 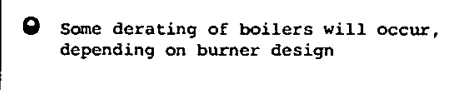 & $\begin{array}{l}0 \text { only bot leers can use hoot ras gas } \\
\end{array}$ & $O$ cold, clean gas not necessary & 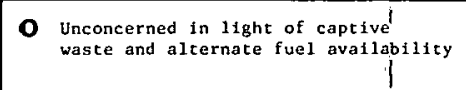 \\
\hline cirponcons & 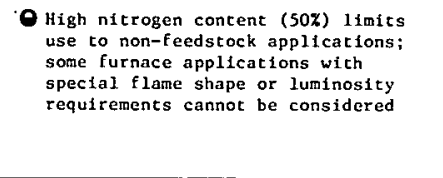 & 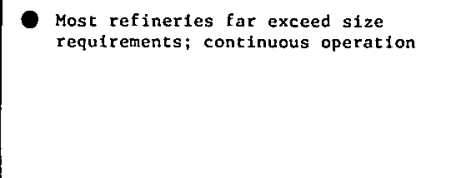 & 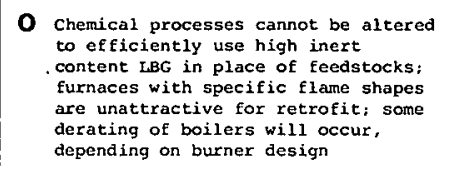 & 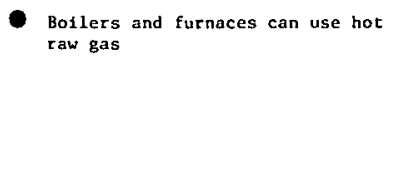 & O cold, clean gas not necessary & 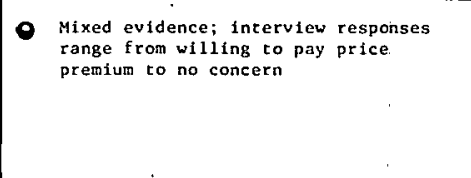 \\
\hline Perroctetum & - Can Eeplicec boller fuels & $\begin{array}{l}\text { - Many plants greater than nintinum size; } \\
\text { hish }\end{array}$ & 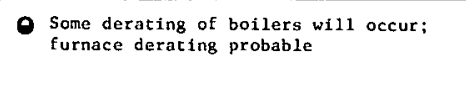 & 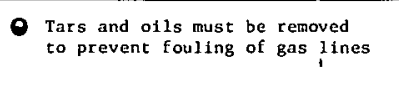 & $\begin{array}{l}\text { - cas cas be sed, but nay not be } \\
\text { necessary }\end{array}$ & 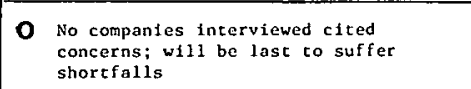 \\
\hline cusss & 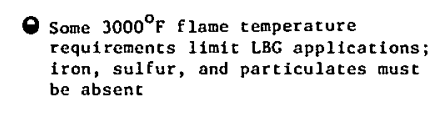 & 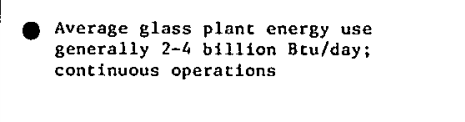 & 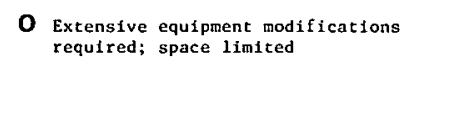 & 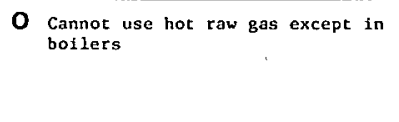 & 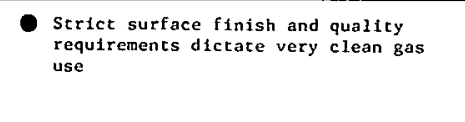 & 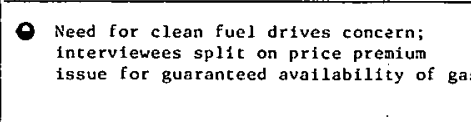 \\
\hline cereserr & 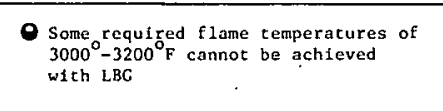 & 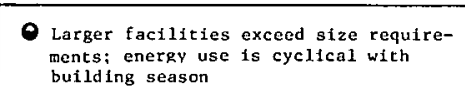 & 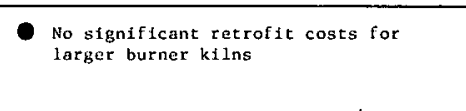 & - can use hot rau gas & 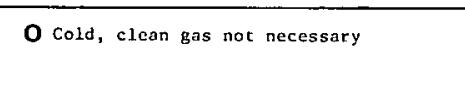 & 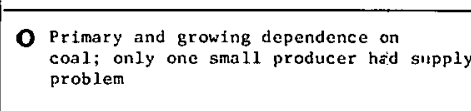 \\
\hline BRाск & - M No probleas Uith LaC vse & 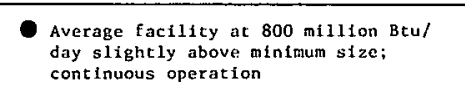 & 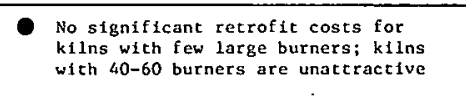 & - Can use hot rau gas & 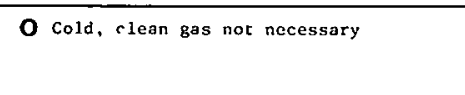 & 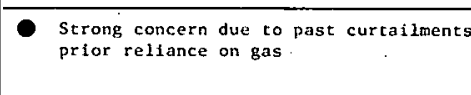 \\
\hline 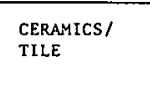 & 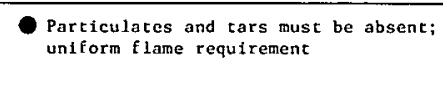 & 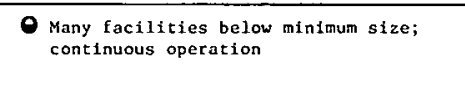 & 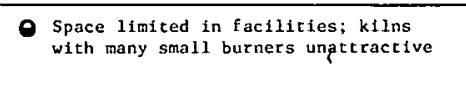 & 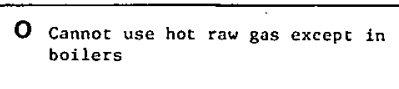 & $\begin{array}{l}\text { - claan gas reutr red for surf face fintsh } \\
\text { and color }\end{array}$ & 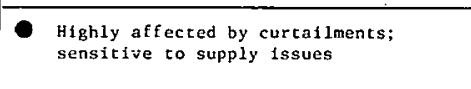 \\
\hline Rerpactron ars & 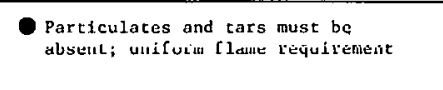 & 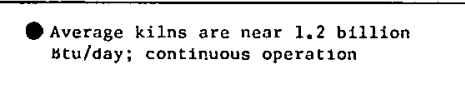 & 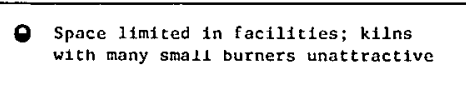 & $\begin{array}{l}\text { Sone products can tolerate a } \\
\text { dotarrod ans }\end{array}$ & 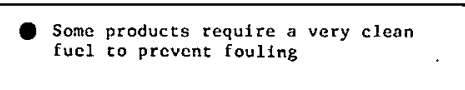 & 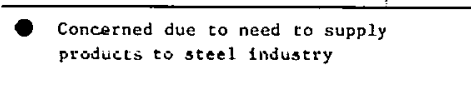 \\
\hline streat & 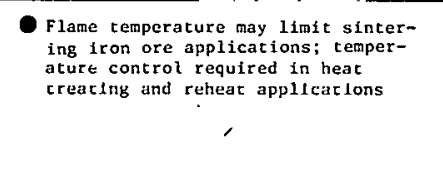 & 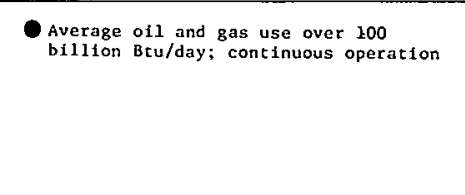 & 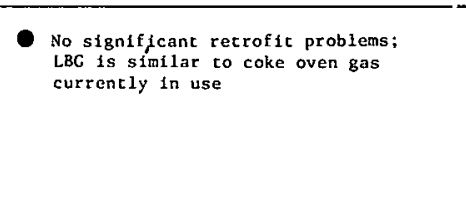 & 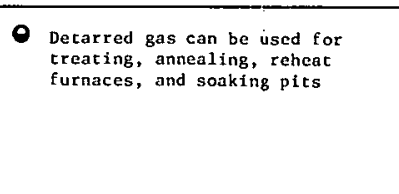 & 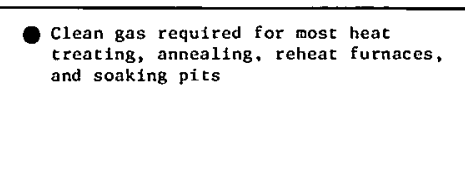 & 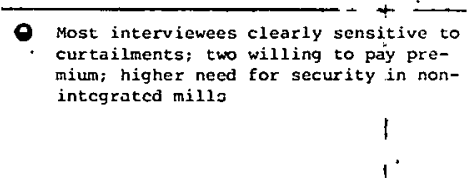 \\
\hline 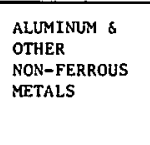 & 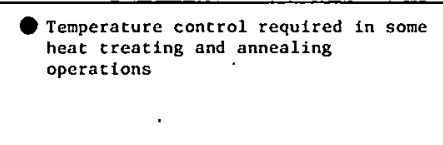 & 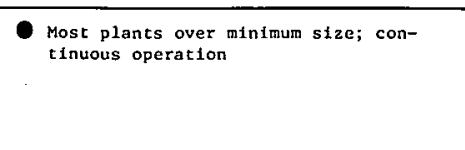 & 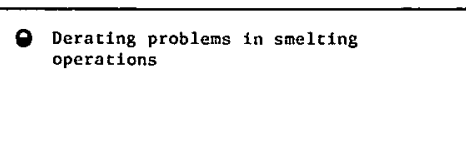 & 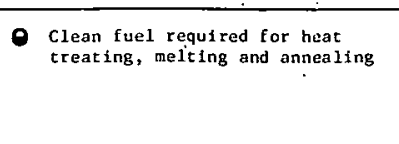 & 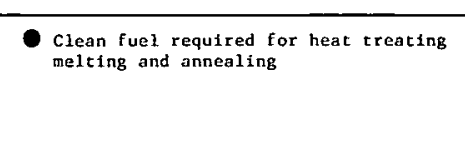 & 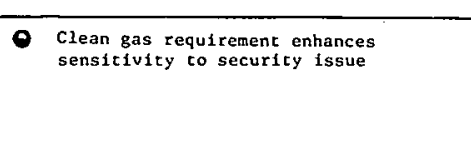 \\
\hline 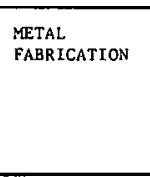 & 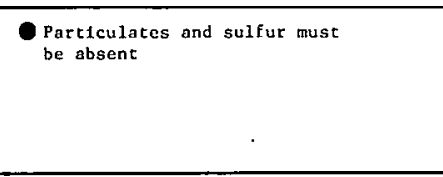 & 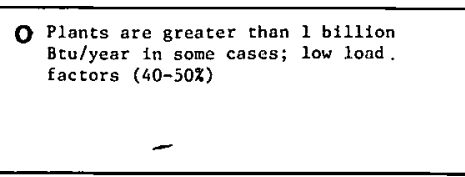 & 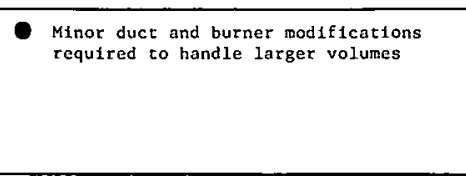 & 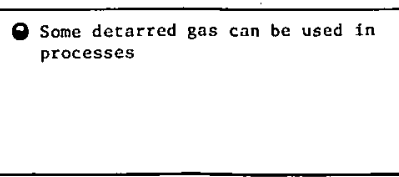 & 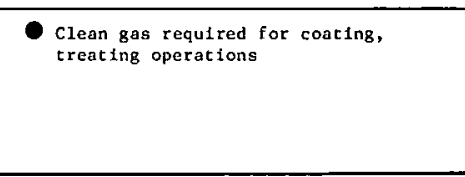 & 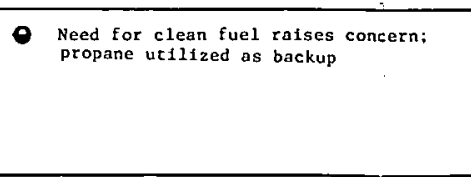 \\
\hline
\end{tabular}

Surces: Industry Interviews (Ail)

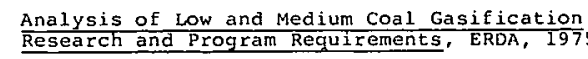

2. Industrial App 1i i ations Study-Industrial plant

- Annual Survey of Manufacturers, 1976 ,

- Industrial Energy Efficiency Improvement

5. Keystone Coal Industry Manual, MeGraw Hi11, 1978.

. Fixed Bed coal Casification for Production of

7. Manufacturers' 1iterature.

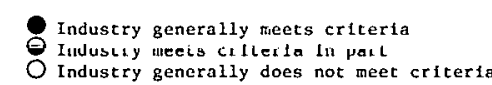




\begin{tabular}{|c|c|c|c|c|c|c|}
\hline \multirow{2}{*}{ rnOusRRY } & \multicolumn{6}{|c|}{ EARLY ADOPTER CHAAACTERISTICS } \\
\hline & $\begin{array}{l}\text { OLI AND GAS AS } \\
\text { PERCENT OF SALES }\end{array}$ & 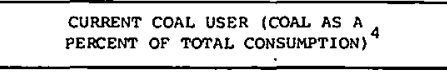 & CAPTIVE COAL SUPPLY ${ }^{5}$ & HICH POEENTIAL LOCATIONS & 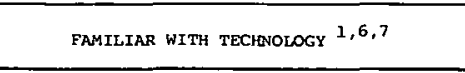 & 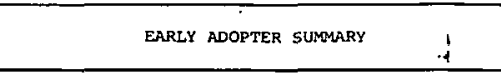 \\
\hline FOOD & O. $0.6 \%$; 10x incentive to invest & - $\begin{array}{c}8.17 \text {; conl used in botlers, not } \\
\text { in process }\end{array}$ & $\bigcirc$ & 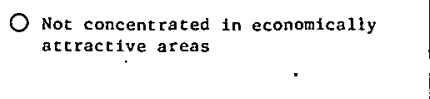 & $\begin{array}{l}\text { - clean gas used in Inditrect product } \\
\text { rossting (past v.S.). }\end{array}$ & 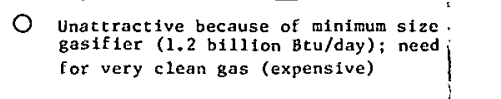 \\
\hline TEXTILES & O 1.08; 1inited incentive to Anvest & $\begin{array}{l}2.0 x_{;} \text {coal used in borlers, not } \\
\text { in process }\end{array}$ & ONo signif tcant reserves held & 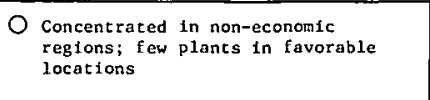 & O No experience with LBG & 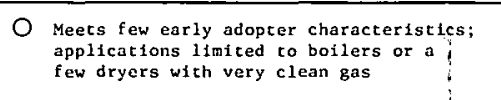 \\
\hline PAQER & 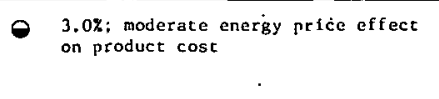 & 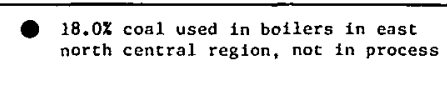 & $\begin{array}{l}\text { Some compantes, depending on location, } \\
\text { oum coal ; } 2 \text { have major reserves }\end{array}$ & 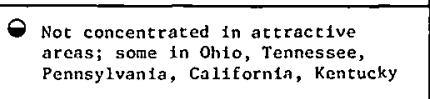 & $\begin{array}{l}\text { Clean gas used in foretgn drying } \\
\text { operazitions }\end{array}$ & 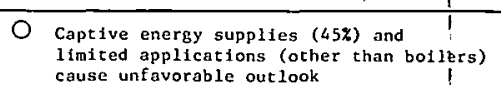 \\
\hline CHFMтсALS & $\begin{array}{l}\text { - } 2.6 \% \text {; moderace energy pritce ef fect } \\
\text { on product cost }\end{array}$ & - $\begin{array}{l}\text { 17.3\%: cona used in boilers, no: } \\
\text { in process }\end{array}$ & 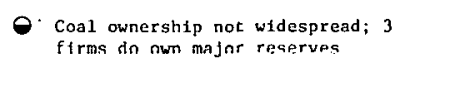 & 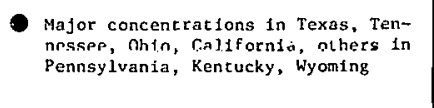 & 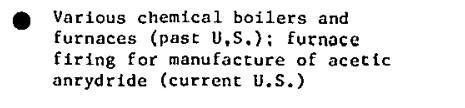 & 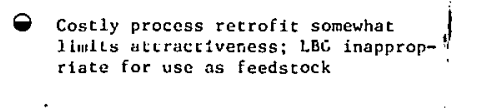 \\
\hline PEтROLIUM & O $1.98 ;$; 10 incentive to thvest & $\begin{array}{l}-11.928 \text { coal used in bollers, some } \\
\text { coke in procecss }\end{array}$ & 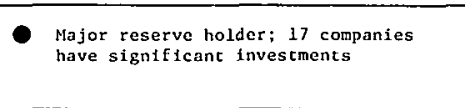 & 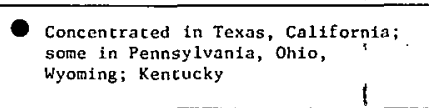 & 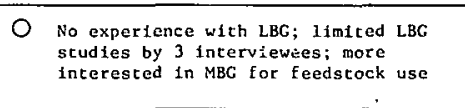 & 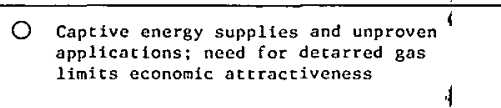 \\
\hline CLASS & 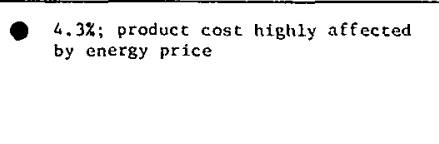 & 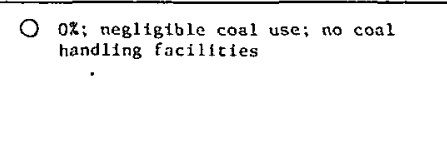 & O No reserves held & 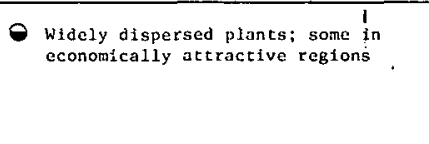 & 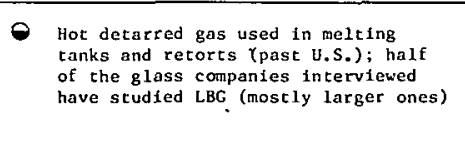 & 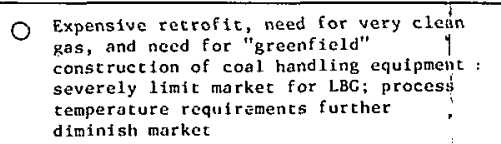 \\
\hline СЕЕЕT & 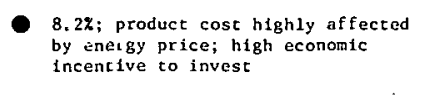 & - $\begin{array}{l}55.0 \% ; \text { coal used co direcclyy fire } \\
\text { kilns }\end{array}$ & 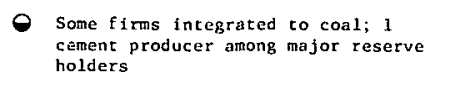 & 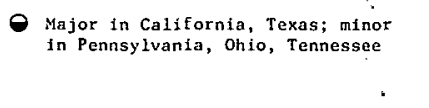 & 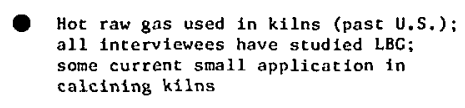 & $\begin{array}{c}0 \\
0\end{array}$ \\
\hline Brick & 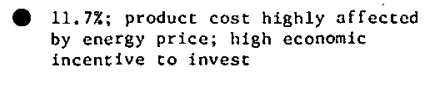 & 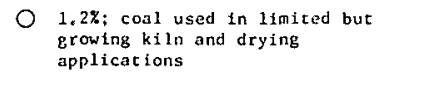 & O No reserves held & - $\begin{array}{c}\text { No major concentrat ions; widcly } \\
\text { dispersed }\end{array}$ & 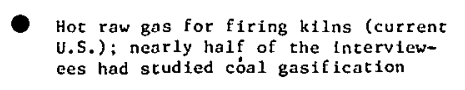 & 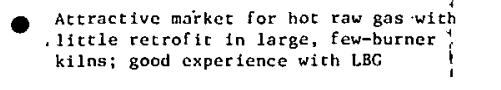 \\
\hline СREMICS & $\begin{array}{l}\text { - 3.6\%: product coss highyy affected } \\
\text { by conergy yrfice }\end{array}$ & 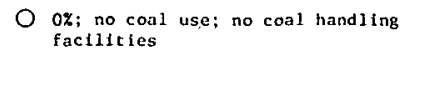 & $O$ No reserves held & 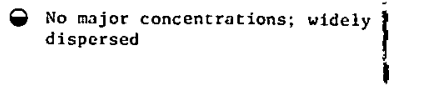 & 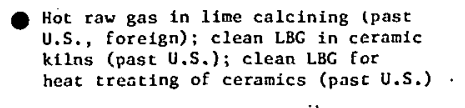 & 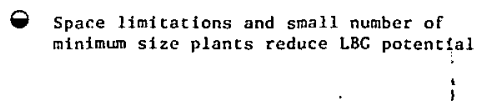 \\
\hline 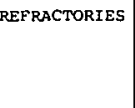 & 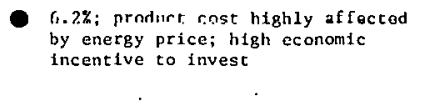 & 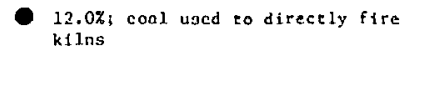 & O No eeserves held & • No najor concencrations; widely & 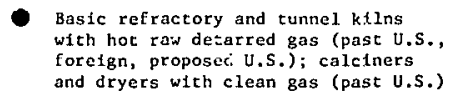 & 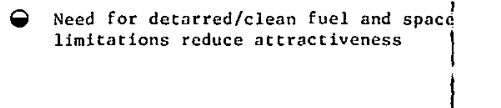 \\
\hline sтеец & $\begin{array}{l}\text { 2.Sz; moderate energy price effect } \\
\text { on product cost }\end{array}$ & 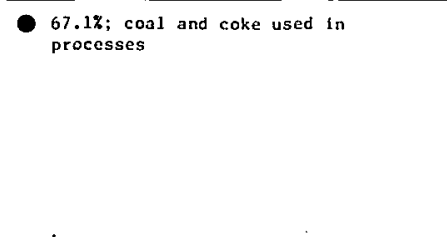 & 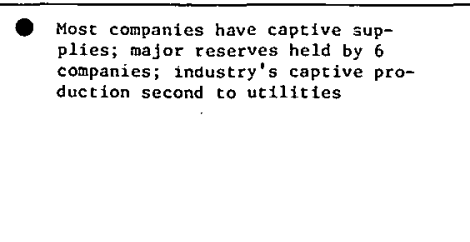 & 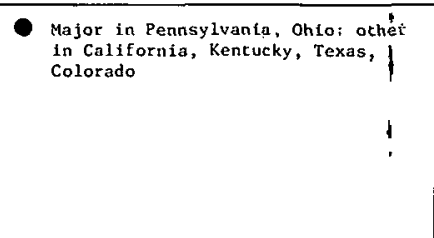 & 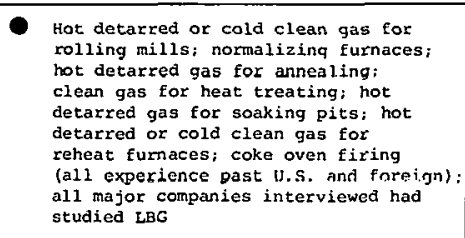 & 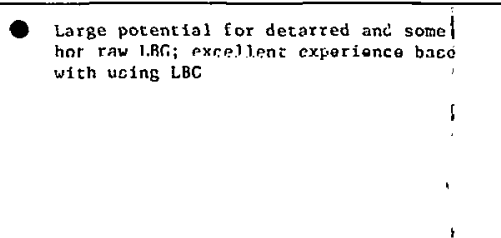 \\
\hline 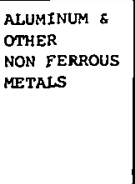 & O 1.37; low Incentive to Invest & 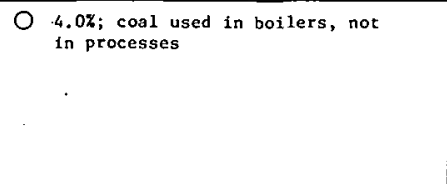 & 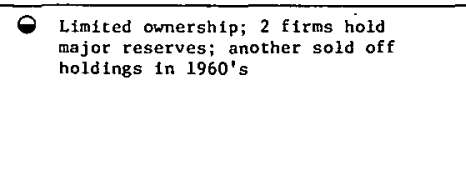 & $\begin{array}{l}- \text { No major concentrations in } \\
\text { actractive areaz; other in Texas, } \\
\text { Tennesee }\end{array}$ & 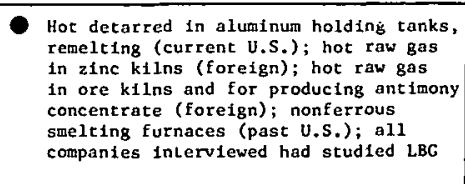 & $\begin{array}{l}- \text { Moderacely actractive in all areas; } \\
\text { need for clean fuel } 1 \text { may hurt economics }\end{array}$ \\
\hline 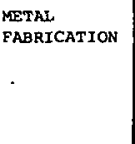 & O 0.57 ; 1ou 1ncentive to invest & 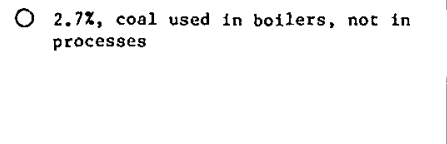 & - & 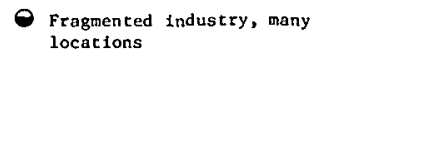 & 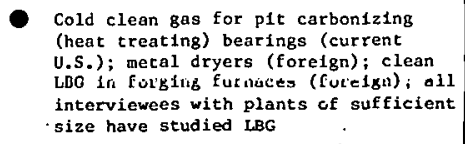 & 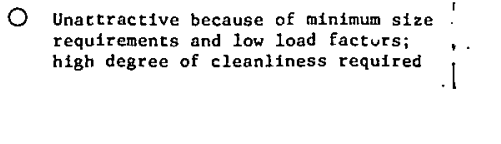 \\
\hline
\end{tabular}

Sources: Industry Interviews ( 111 )

Analysis of Low and Medium Coal Gasification
Nesearch and Program Requirements, ERA,

Industrial Applications Study-Indugtrial plant

3. Annual Lurvey of manufacturers, 1976 ,

4. Industrial Energy Eeficiency. Improvement

Keystone Coal Industry Manual, McGraw Hill, 1970

- Fixed Bed Coal Gasification for Production of

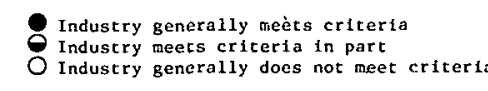


requirements leads to the conclusion that 3 to 5 gasifiers will be installed by 1985 . These, most likely, will be installed by the major firms who are forward-thinking/ innovators in their industry. The gasifiers are likely to be pilot scale, to investigate effects on product quality and energy balance in the plant. Full-scale introduction is not expected until the industry can examine the problems of balancing this additional energy form in their complex operations.

Brick. While there are some installations that do not pass the minimum size criteria, the ability of brick kilns to use hot raw gas with minimum retrofit and the industry's high sensitivity to oil and gas cost and supply place the brick industry as a high potential early adopter. In light of rapidly rising delivered oil prices--now quoted in excess of $\$ 3.60$ per million Btu--hot raw gas, estimated at $\$ 3.53$ per million Btu in Exhibit III-ll, is becoming highly attractive for brick manufacturers dependent on fuel oil. Additionally, the existence of a current domestic LBG application (Glen-Gery Corporation) removes many of the perceptions of interference with product quality or process operation. The excellent fit in this smaller but more likely industry leads to an estimate of 3 to 5 new gasifiers by 1985, most likely by the larger users in the economically attractive areas shown in Chapter VI.

(3) Aluminum and Other Non-ferrous Metals,

Refractories, Ceramics/Tile, and Chemicals Form a Group of Moderately Attractive Industries

LBG is less attractive for use in this group of industries. An overall penetration of 3 to 5 gasifiers is expected, scattered throughout the group of industries. Most will be pilot size to investigate effects on products and processes. Outlooks for each industry are discussed below: 
Aluminum and other non-ferrous metals. Although the technical fit with LBG is as good as in the steel industry, the retrofit of certain operations is reported to be more difficult in this group. While more sensitive to natural gas supplies, the incentive to invest is lower, with oil and gas at only 1.3 percent of sales. Two-thirds of the energy used in the aluminum industry is electricity, and as such, its availability and price is the driving factor. A current. domestic installation (Howmet) reduces the technical uncertainty of LBG use in the aluminum industry. Limited coal use and captive reserves and the lack of concentration in the economically attractive areas tends to reduce the overall attractiveness.

Refractories. While the screening profile for this group and non-ferrous metals are similar in feasibility and attractiveness, this group has fewer early adopter characteristics. Coal is currently used to fire certain refractory kilns, thus directly competing with LBG. While there is a higher incentive to sut oil and gac ooets, the industry is not concentrated in the economically attractive regions and requires--in some cases--a relatively rlean gas, firther reducing the attractiveness.

Ceramics/Tile. There are few facilities which have the capacity and load factors required to utilize LBG. Space limitations will affect the total retrofit costs. However, since the industry has a high need fur a clean gas, has been curtailed in the past, and has an economic incentive to cut oil and gas costs, there is a limited market for LBG. Past domestic and foreign experience in using LBG enlanies the attractivences, but pollelration is not expected to be significant.

Chemicals. IIigh retrofit costs and'the inability to use LBG as a feedstock significantly reduce the expected market. However, captive coal held by a few companies and the existence of coal handling facilities, coupled with concentrations in the economically attractive areas offset the retrofit cost penalty. 
Since hot raw gas can be used, and there is moderate sensitivity to oil and gas supply, the chemicals industry cannot be ruled out as an attractive early adopter with moderate potential.

(4) Glass, Cement, Metal Fabrication, Petroleum, Paper, Textiles, and Food Each Have Major Barriers to LBG Use

Each of these industries has specific requirements or operating situations which effectively limit the market for low-Btu gas from coal. Very minor penetration of this market is expected, 0 . to 3 gasifiers by 1985. The few installations, if any, will only be pilot units, designed to test the effect of LBG on product quality, since there are limited immediate advantages to full-scale installation. The major limiting factors in each industry are discussed in the following sections:

Glass. The poor technical fit of LBG with certain glass processes and the high degree of retrofit required effectively limit the glass market. Process need for a very clean gas and the requirement to spend additional capital for coal handling facilities further reduce the economic attractiveness.

Cement. The large and growing use of direct coal-fired kilns diminishes the need for gasification, except in areas where environmental regulations preclude the direct burning of coal.

Metal Fabrication. The many facilities with very"low. load factors (30 to 50 percent) drive the economics of LBG so as to become unattractive. Additionally, the low sensitivity to oil and gas supplies and cost remove the incentive to invest.

Petroleum. The petroleum industry generates much of its own energy through the use of tars, oils, off gases, and other non-marketable products which can be burned in boilers and process heaters. The high degree of captive, inexpensive wastes and the low sensitivity to oil and gas costs for non-feedstock applications effectively block LBG use in this industry. Industry interviews confirmed little near-term interest by refiners in coal gasification. 
- Paper. A similar captive waste situation exists with this industry. Forty-five percent of the paper industry's energy requirements are supplied internally. Low-Btu gas cannot economically compete with the inexpensive waste products for use in boilers, where only a low quality fuel is required. However, rising oil prices may make hot raw gas an ttractive replacement for oil used under boilers, where environmental restrictions preclude direct coal combustion.

- Textiles. Few early adopter characteristics are shown in the textiles summary. The use of LBG for arying could only be accomplishen if the gas was very clean, since the product would act as a filter, trapping impurities and particulates in the gas stream. The alternate use for TRG in this innistry is in boilers, where it would compete with direct coal firing and other lower quality, less expensive fuels. This situation, coupled with a low economic incentive to cut oil and gas costs, little concentration in economically attractive areas, and no experience with LBG cffoctiycly blocks coal gasifiealion pentelda tion for the near-term.

- Food. This situation parallels textiles. Very high process gas quality is required to prevent food contamination and to meet FDA requirements. The alternative use in boilers again competes with many lower quality, less expensive fuels. With poor economics and limited sensitivity to gas supplies (high priurity user) and cost, food is a poor market for LBG.

(5) Low-Btu Gasifiers for Electric Power Generation WII Be Linited to 1 or 2 New installations by iysb

The use of industrial on-site combined cycle electric power generation in another potential use for low-Btu coal gasification. Today.'s in-plant proportion of electricity generation is approximately 10 percent, as shown in Exhibit VII-4. Facilities which currently generate the greatest percentage of their own electricity are: 
EXHIBIT VII-4

Major Electricity Generating Industries

(1975)

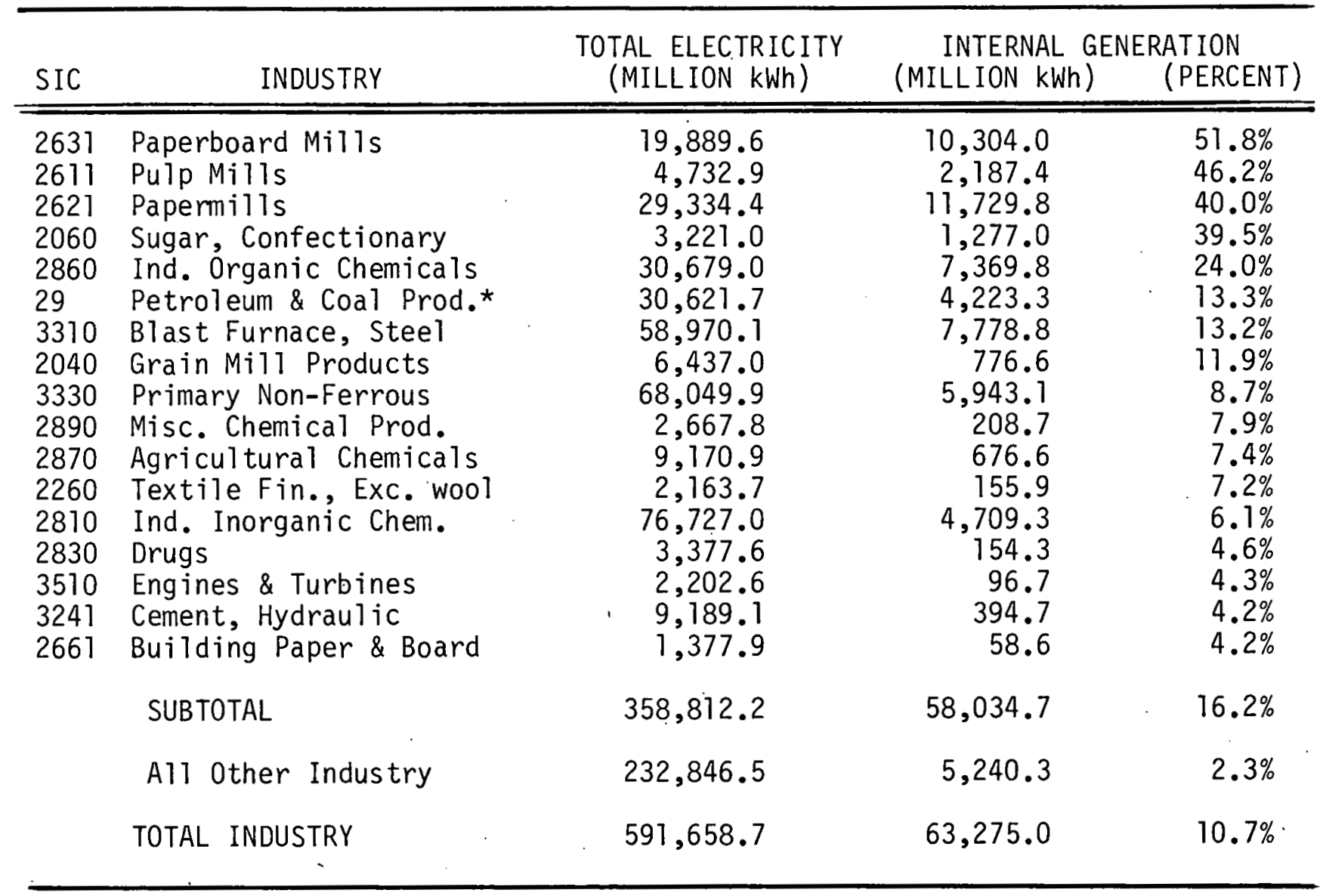

* Petroleum refining accounts for over 81 percent of electricity consumed in SIC 29.

SOURCE: U.S. Department of Commerce, Annual Survey of Manufacturers 1975: Fuels and Electric Energy Consumed, September 1977. 
- Paper-related plants and sugar plants. These industries have large amountscof waste materials that are difficult to dispose of, highly combustible, and easily used as boiler fuel for steam generators.

- Chemical plants and petroleum refining. These facilities use large volumes of steam that are easily adaptable to cogeneration or they use large amounts of electricity on a constant basis, which makes internal generation economically attractive. In addition, there are sevfral Galivive Hubustble wastes (e.g., tarc, oils) which are of low value and can be burned to raise steam.

According to an EPRI paper titled "The Near-Term Potential for Gasification-Combined Cycle Electric Power Generation," technology should be available in the latter half of the 1980's for gasification-generated electric power. A chemical manufacturer currently is in the start-up phase on a $15 \mathrm{MW}$ low-Btu combined cycle pilot unit to produce process steam and electricity. This evidence suggests that it is likely that a commercial. scale unit or two will be in place by 1985, most likely in the chemical or petroleum industry, because of their experience with power generation and experience in optimizing energy flows.

(6) Despite the Good Fit of LBG With certain Applications, There Are Several Barriers to Be Overcome to Increase Market penetration

Several major barriers exist to the widespread penetration of LBC. These factors reduce the realistic market to 10-20 gasifiers, where the maximum reasonably feasible market as discussed in Chapter $V$ is in excess of 3500 gasifiere:

Economics. The marginal-to-poor economics of low-Btu gas relative to natural gas prices is a major limiting factor, since natural gas would in most cases be the fuel displaced by LBG. However, the surging prices of oil, reflected by the May 25, 1979 data in Exhibit VII-5, have made hot raw LBG gas competitive with \#2 fuel oil in certain cases, indicating a major potential market for companies where distillate is the swing fuel. 
EXHIBIT VII-5

Comparison of Typical Industrial

Costs, 1979

\section{Fuel}

$\operatorname{Coat}^{1}$

No. 2 Fuel $0 i]^{2}$

No. 6 Fuel $011^{2}$

Natural Gas ${ }^{1}$

Low-Btu Gas ${ }^{3}$ :

- Hot ràw

- Cold clean
$\$ / M i l 1$ ion Btu

$\$ 0.62-2.27$

$\$ 3.60-3.95$

$\$ 2.60-3.18$

$\$ 1.12-3.32$

$\$ 2.74-4.78$

$\$ 3.39-6.28$

1. Prices as of February 1979, from interviews with energy suppliers.

2. "Platt's 0ilgram Price Report", May 25, 1979

3. Exhibit III-16 
If significant increases in OPEC prices are coupled with further domestic decontrol of oil, the attractiveness would be greatly enhanced, and further shifts to hot raw LBG and even cold clean gas would be expected. For gas and other fuels, LBG is not currently competitive, as shown in Exhibit VII-5.

Although volatile market conditions may change that situation in the future, severe price increases like those of oil are not expected to occur in the near term. Because most companies interviewed stated that economics must support any decision to invest in alternate energy technologies, and because less than 15 percent of the firms would be willing to pay even a small price premium for LBG under conditions of supply risk, the market is limited to:

- Targer or more innovative companies who treat gasification as $R \& D$ or as a trial unit for testing effects of the gas on product quality.

- Companies currently dependent on \#2 fuel oil.

Interviewces' perceptions of LBG costs:.in the $\$ 4-\$ 5 / \mathrm{million}$ Btu range indicate that the economic data is available and believed by industry.

Retrofit. No data was found during the course of this study that categorized retrofit costs or engineering requirements with industrial processes. Nearly all of the interviewees perceived.retrofit of existing processes as being a significant factor limiting the use of coal gasification, but no hard evidence was available from them to support this perception. The removal of this barrier would allow full cost ecunumic arlalyses to be performed by companies considering gasitication, reducing the economic uncertainty.

Applications. Like retrofit data, little information was available on the technical limitations to LBG use in specific processes. Generalizations about flame characteristics 
and furnace design were frequently voiced but no rigid compilation of application-oriented data was found in industry or the literature. Information on this subject would remove some of the technical uncertainty about $L B G$ in modern processes.

Need for alternate fuels: Interviewees stated that with the government position toward increasing the industrial use of natural gas and the assurance of their gas suppliers of sufficient volumes to meet demand for the next few years, no sense of urgency was felt to switch to a more expensive alternate fuel. Dual fuel capabilities in most plants and the willingness of others to pay for propane as a back-up fuel further reduces supply security risk.

Availability of direct coal burning technologies. As direct burning of coal is developed for use in more processes, the potential market for LBG will shrink. Coal is already directly used in cement, brick, and some refractory kilns and some firms interviewed are investigating direct burning in other areas.

Uncertainty. The respondents felt uncertainty over federal policies on three major topics:

- Energy pricing, not knowing the long-term price policies on oil, gas, and coal.

- Fuel use, concerned over the ability to switch back to oil and gas once gasification had been installed and proven as well as uncertainty over being forced away from oil and gas.

- Environmental regulations, and the increasing cost of keeping plants and potential gasification installations within changing environmentall guidelines.

This section completes the identification of early LBG adopters and key LBG barriers. The next section addresses MBG. 
2. THE 1985 MARKET FOR SINGLE-USER MEDIUM-BTU GASIFICATION IS FORECAST TO CONSIST OF AT MOST TWO OR THREE PLANTS, MOST LIKELY IN THE CHEMICAL AND PRIMARY METALS INDUSTRIES

Analysis of the near-term market for MBG, single-user gasifiers resulted in an estimate of two to three gasifiers installed by 1985. The following section briefly describes screening criteria, after which each industry is assessed.

(1) The Expected Early Market for Single-User MBG Is Identified By Examining Ten Criteria Relating to Technical Feasibility, Basic Attractiveness, and Early Adoption Characteristics

The feasibility criteria for installing MBG include factors concerning technical applicability of the gas itself, and the ability of potential users to achieve adequate capacity utilization of the gasification system. These factors, examined in depth in Chapter. V, include:

- Criteria relating to the properties of MBG gas itself, including MBG gas flame characteristics, and chemical compositions of MBG gases

Criteria relating to plant capacity utilization, including minimum feasible plant capacity-generally about 10 billion Btu/ day--and high plant load factors.

The criteria of basic attractiveness are designed to assess the extent to which MBG offers a fit with the needs of potential users, including user requirements for a clean gaseous fuel, and that gasification provides protection against interruptions in natural gas supplies.

The criteria for early adoption define the charm acteristics of industrial customers most likely to be the first to install $\mathrm{MBG}$ in a single-user configuration. Although firms meeting these criteria cannot be designated as "certain" adopters of MBG, industrial interviews indicated that these factors are highly correlated to companies which will be the early adopters of the process. The criteria include: 
A high oil and gas cost, defined as a percent of total sales, indicating an industry's sensitivity to changes in energy. costs.

- Current coal usage, defined as coal's portion of total energy consumption in an industry, assessing the industry's experience in coal handling, usage, and waste disposal.

Captive coal supplies, measured in terms of the ownership of coal reserve properties of greater than 50 million tons, indicating access to and interest in potentiaily lowcost coal.

Familiarity with gasification technology, indicating industry's knowledge and current-or past--applications of coal gasification, and the similarity of MBG to their present energy-u'sing technologies.

- Energy innovation, defined in terms of the proportion of revenues spent for $R \& D$ and the industry's involvement with new energy supply or conservation projects, as indications of its likelihood to install a largely unproven technology.

- Locations in high potential areas, the nine states identified in the regional analysis as most likely to offer a match between the economicaliy attractive areas and locations with potential supply problems.

These ten criteria are arrayed against the selected industries as shown in summary Exhibit VII-6. The last column of the chart summarizes the analysis by identifying the most likely early-adopting industries. Detailed comments correlating to the summary chart are shown in Exhibit VII-7. The following sections present key . results. 
EXHIBIT VII-6

Industry Screening Summary

Medium-Btu Gasification: Sinçle-User Plants

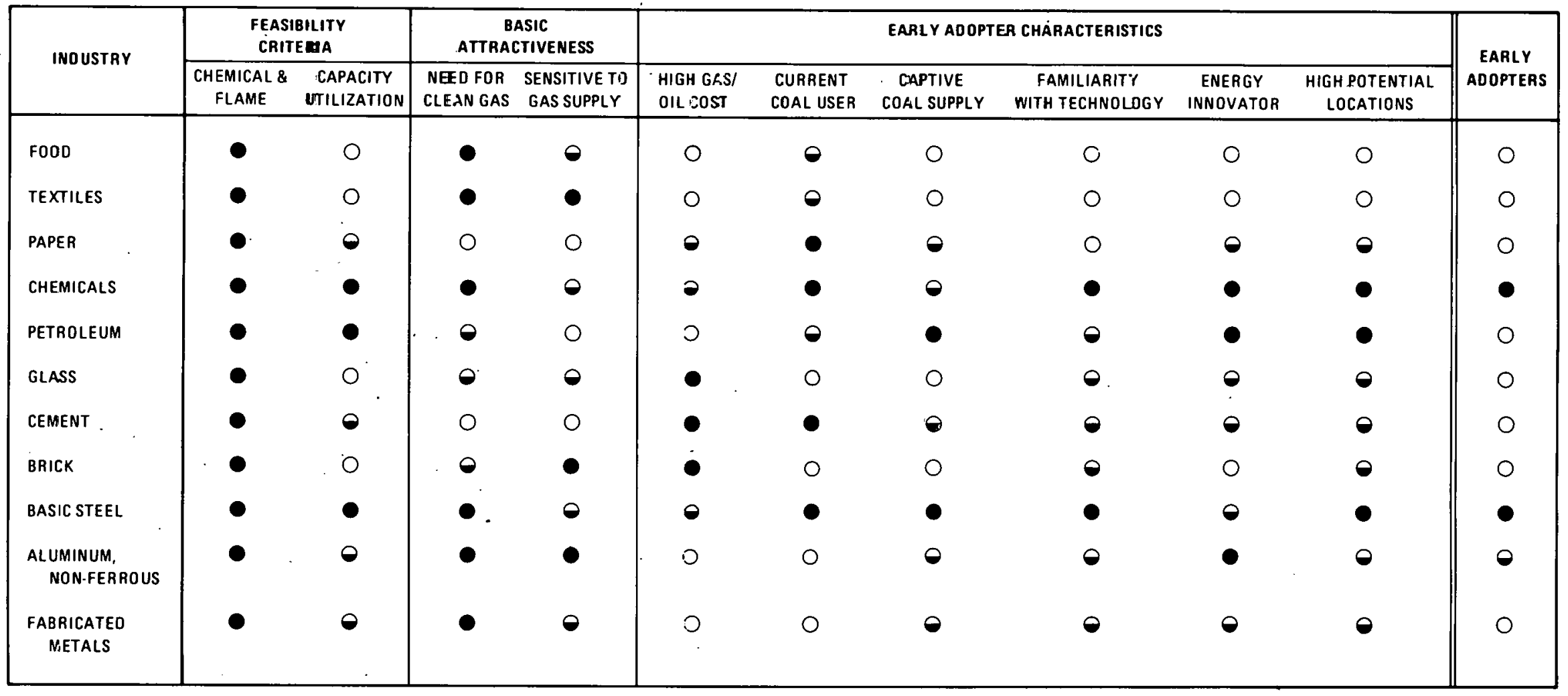

KEY: : INDUSTRY MEETS CRITERION

: INDUSTRY MEETS CRITERION IN PART

O: INDUSTRY DJES NOT MEET CF.TERION

SOURCE: BASED ON EXHIBIT VII-7 


\begin{tabular}{|c|c|c|c|c|c|c|c|c|}
\hline \multirow[b]{2}{*}{ INDUSTRY } & \multicolumn{4}{|c|}{ FEASIBILITY CRITERIA } & \multicolumn{4}{|c|}{ BASIC ATTRACTIVEIJESS CRITERIA } \\
\hline & & $\begin{array}{l}\text { GAS FLA:T. CHARACTERISTICS AND CHEMICAL } \\
\text { COMPOSITION } 1,2\end{array}$ & & CAPACITY UTILIZATION ${ }^{1}, 3$ & & NEED FOR CLEAN GASEOUS FUEL 1,2 & & SENSITIVE to Natural. Gas ŚUPplies ${ }^{1}$ \\
\hline FOOD & - & $\begin{array}{l}\text { MBG gas can be widely used to replace natural gas, } \\
\text { since gas combustion characteristics are similar }\end{array}$ & 0 & $\begin{array}{l}\text { MBG facilities generally infeasible: plant sizes are } \\
\text { too small; patterns of energy demands vary diurnally } \\
\text { and seasonally }\end{array}$ & - & $\begin{array}{l}\text { Clean gaseous fuel required for many processes, due } \\
\text { to food quality standards }\end{array}$ & 0 & $\begin{array}{l}\text { Availability of back-up propane reduces sensitivity } \\
\text { to natural gas supplies, although some concerns are } \\
\text { still apparent }\end{array}$ \\
\hline TEXXILLE & - & $\begin{array}{l}\text { MBG can replace natural gas: combustion } \\
\text { characteristics of gas are similar }\end{array}$ & 0 & $\begin{array}{l}\text { MBG plant feasibility is unlikely: largest } 20 \text { of } \\
\text { industry's sooo plants consume about } 8 \text { billion } \\
\text { Bdu/day, most are considerably smaler; energy } \\
\text { demands are generally continuous }\end{array}$ & - & $\begin{array}{l}\text { Textile manufacturing requires extremely clean fuel } \\
\text { in most operations }\end{array}$ & $\bullet$ & $\begin{array}{l}\text { Industry is generally concerned with gas supplies, } \\
\text { due to need for clean fuel, past history of curtail- } \\
\text { ments }\end{array}$ \\
\hline PAPER & • & $\begin{array}{l}\text { MBG gas can be used to replace other fuels, since } \\
\text { more than } 70 \text { percent--90 percent in large mills-of } \\
\text { energy use is for raising steam (Ex. V-7) }\end{array}$ & $\boldsymbol{0}$ & 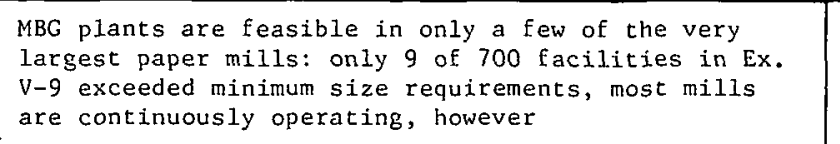 & 0 & $\begin{array}{l}\text { Need for clean gaseous fuels is low: boiler uses } \\
\text { account for great bulk of consumption; relies on } \\
\text { residual oill forest wastes, coal. Gas required } \\
\text { only in specialized coating dryers }\end{array}$ & 0 & $\begin{array}{l}\text { Industry is not concerned with natural gas supplies } \\
\text { in light of use and availatility of other, cheaper } \\
\text { fuels }\end{array}$ \\
\hline CHEMICALS & $\bullet$ & $\begin{array}{l}\text { IBRG can widely replace natural gas in boilers and } \\
\text { furnaces. MBG can also replace natural gas as as } \\
\text { feedstock in many applications, due to high } \mathrm{H}_{2} / \mathrm{cos} \\
\text { concentration, low methane and inert contents }\end{array}$ & $\bullet$ & $\begin{array}{l}\text { MBG plants are feasible; at least } 75 \text { major plants } \\
\text { exceed minimum size (Ex. V-9); plant load factors are } \\
\text { high (80-90\%), as a continuous process industry. }\end{array}$ & - & $\begin{array}{l}\text { Need for clean, gaseous fuels is high due to feed- } \\
\text { stock requirements. Need for clean fuels not that } \\
\text { important for process heat, boiler applications }\end{array}$ & 0 & $\begin{array}{l}\text { Evidence is mixed: some companies report strong } \\
\text { concern; one willing to pay premium for secure } \\
\text { supplies; other firms, less worried; 2 unwilling to } \\
\text { pay any premium }\end{array}$ \\
\hline PETROLEUM & $\bullet$ & $\begin{array}{l}\text { MBG gas can feasibly replace purchased natural gas } \\
\text { now fueling boilers and process hearers }\end{array}$ & - & $\begin{array}{l}\text { MBG gasification is feasible: more than } 50 \text { of } 250 \\
\text { refineries consumed more than } 15 \text { binilion Btuday of } \\
\text { natural gas (Ex. V-9); ; energy demands are continuous }\end{array}$ & $\mathbf{0}$ & $\begin{array}{l}\text { Need for clean, gaseous fuels is limited, boilers } \\
\text { are a major share of energy consumption, and process } \\
\text { furnaces show only moderate requirements for clean } \\
\text { gaseous fuels }\end{array}$ & 0 & $\begin{array}{l}\text { Little sensitivity to natural gas supplies: no } \\
\text { companies in interviews cited particiular concern over } \\
\text { gas supplies; many felt that, as energy companies, } \\
\text { they would be the last to suffer from supply short- } \\
\text { falls }\end{array}$ \\
\hline GLASS & - & $\begin{array}{l}\text { MBG can feasibly replace natural gas; combustion } \\
\text { characteristics of gases are similar; can be used } \\
\text { in melting, forming, scrapping }\end{array}$ & 0 & $\begin{array}{l}\text { Feasibility of MBG is limited: average plant size, } \\
\text { smaller than in past, ranges from } 2 \text { to } 4 \text { billion } \\
\text { Btulday, energy demands are generally continuous }\end{array}$ & 0 & $\begin{array}{l}\text { Need for clean, gaseous fuel is moderate: glass } \\
\text { melting, accounting for } 70 \% \text { of energy use, can use } \\
\text { oil for most part, if necessary; other processes, } \\
\text { including forming, cunting and annealing, require } \\
\text { gas }\end{array}$ & 0 & $\begin{array}{l}\text { Because of availability of back-up propane, many } \\
\text { companies not concerned with securityty-two would } \\
\text { pay no premium; however, two with curtailment } \\
\text { history willing to pay premium }\end{array}$ \\
\hline CEMENT & & $\begin{array}{l}\text { MBG can widely replace natural gas, coal, or other } \\
\text { fuels now used in the kiln. Some companies feel that } \\
\text { MGG would even be technicalily superior to coal, which } \\
\text { now supplies most requirements }\end{array}$ & 0 & $\begin{array}{l}\text { Feasibility of MBG plants limited: } 169 \text { of } 172 \\
\text { plants in one study used less than } 15 \text { billion Btu/day } \\
\text { (Ex. V-9), typical plant consumption of fossil fueis } \\
\text { from } 15-12 \text { billion Btu/day; energy demands yually } \\
\text { continuous }\end{array}$ & 0 & $\begin{array}{l}\text { Need limited: because combustion products mostly } \\
\text { absorbed in product, can use other fuels; industry } \\
\text { rapid1y moving to more than } 75 \% \text { coal dependence }\end{array}$ & 0 & $\begin{array}{l}\text { Because of primary, and growing, dependence on coal, } \\
\text { little sensitivity is apparent on natural gas } \\
\text { suppities; only one small cement producer has had any } \\
\text { major problems due to supply shortfalls } \\
\text { - }\end{array}$ \\
\hline BRICK & & $\begin{array}{l}\text { MBG gas can widely substitute for other fuels, } \\
\text { incr.luding natural gas }\end{array}$ & 0 & $\begin{array}{l}\text { - Feasible MBG applications are limited: typical plant } \\
\text { size ranges from scucral hundrcd million to } 2 \text { billion } \\
\text { Butday, below accepted size minimums; energy use is } \\
\text { mostly continuous }\end{array}$ & 0 & 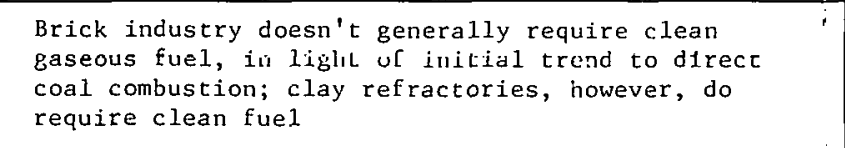 & - & $\begin{array}{l}\text { Most firms interviewed indicated a strong concern with } \\
\text { gas securicy, due either to past curtailments or, in } \\
\text { the case of refractorias, the critical need to } \\
\text { maintain production to supply the steel industry }\end{array}$ \\
\hline $\begin{array}{l}\text { BASIC } \\
\text { STEEL }\end{array}$ & • & $\begin{array}{l}\text { Due to similarity of combustion characteristics to } \\
\text { natural gas, MBG can be used in many applications: } \\
\text { sintering, coke ovens, steee furnaces, soaking pits, } \\
\text { reheating, heat treating and annealing, finishing, } \\
\text { boilers }\end{array}$ & - & $\begin{array}{l}\text { MBG plants are feasible: at least } 46 \text { facilities } \\
\text { consume more than } 15 \text { billion Bru/day in gas (Ex. V-9); } \\
\text { energy demands are usually continuous, with plant load } \\
\text { factors of about } 70 \% \text { in integrated mills }\end{array}$ & $\bullet$ & $\begin{array}{l}\text { A1though industry can technically use oil for more } \\
\text { than } 70 \% \text { of purchased fued requirements, clean gas } \\
\text { is essential for heat treating, annealing, some } \\
\text { reheating }\end{array}$ & 0 & $\begin{array}{l}\text { Data mixed on need for fuel security: most inter- } \\
\text { viewed companies clearly concerned, two will pay } \\
\text { premium; one will not pay premiun; need for secure } \\
\text { supplies higher in non-integrated than integrated } \\
\text { mills. }\end{array}$ \\
\hline $\begin{array}{l}\text { ALUMINUM \& } \\
\text { OTHER } \\
\text { NONFERROUS }\end{array}$ & & $\begin{array}{l}\text { IBG can replace current natural gas and other fossil } \\
\text { fuels in most processes: melting and holding fing } \\
\text { furnaces, heat treating and annealing, fabrication; } \\
\text { MBG can be used to displace current self-generator } \\
\text { fuels }\end{array}$ & 0 & $\begin{array}{l}\text { MBG plant feasibility is possible: 11 of } 31 \text { plants in } \\
\text { E. V V - } 9 \text { consumed more than } 15 \text { billion Btulday, in } \\
\text { excess of minimum size requirements; energy demands } \\
\text { are continuous }\end{array}$ & $\bullet$ & $\begin{array}{l}\text { Although electricity supplies about } 70 \% \text { of energy } \\
\text { requirements, clean gaseous fuel is required for } \\
\text { melting furnaces, heat treating \& annealing }\end{array}$ & - & $\begin{array}{l}\text { Companies' requirements for clean gas makes them } \\
\text { sensitive to security of natural gas supplies }\end{array}$ \\
\hline $\begin{array}{l}\text { FABRICATED } \\
\text { HETALS }\end{array}$ & & $\begin{array}{l}\text { MBC can be substituted for natural gas in all major } \\
\text { processes, due to similarity of combustion mat of } \\
\text { characteristsics to natural gas: melting, metal } \\
\text { recovery, forging, heat treating }\end{array}$ & 0 & 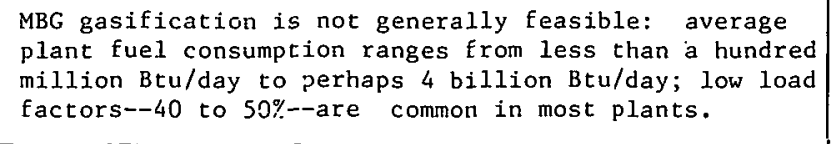 & [• & $\begin{array}{l}\text { Many processes require clean fuel: metal coating and } \\
\text { decorating needs premium ambient; many metal cans } \\
\text { need food-quality atmosphere; some heat treating } \\
\text { requires fuels free of sulfur and vanadium }\end{array}$ & 0 & $\begin{array}{l}\text { Evidence is mixed: some industries are concerned } \\
\text { with gas supplies, due to need for clean fuel; } \\
\text { others less sensitive are willing to rely on pro- } \\
\text { pane back-up for their clean fuel }\end{array}$ \\
\hline
\end{tabular}

KEY: - Industry generally meets criterion $\mathbf{Q}=$ Industry meets criterion in part $\mathbf{O}=$ Industry generally does not meet criterion

2. Analysis of Low and Medium-Btu Coal Casification Research and Development Program, of fice of Fossil Energy, Energy Research and Development Admin., 1975 


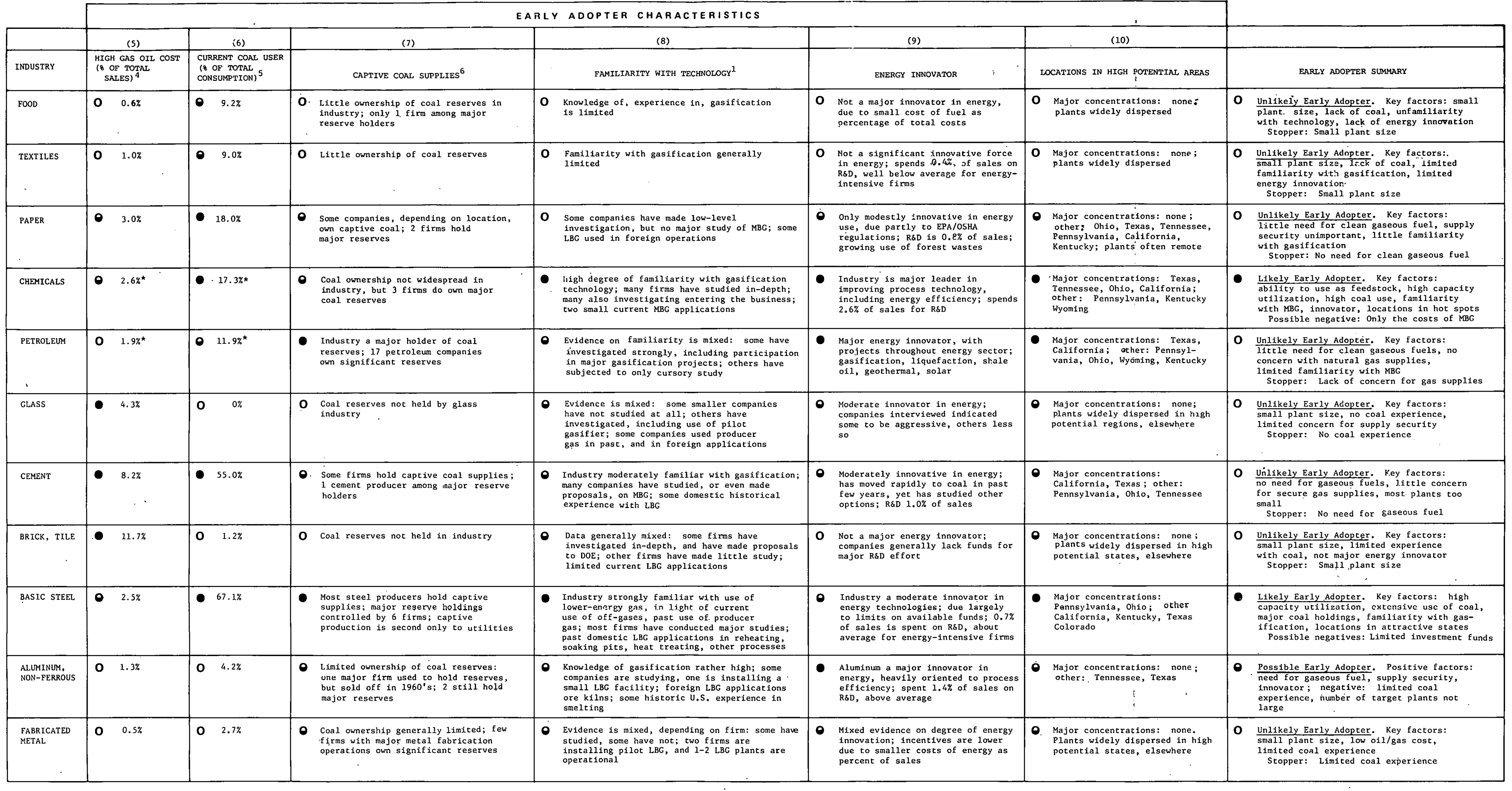

Source: Industry Interviews

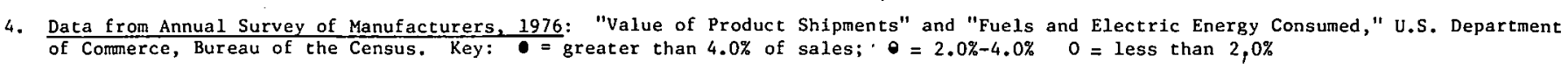

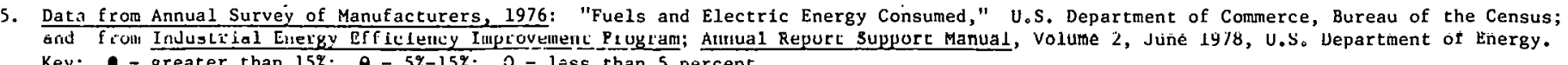

6. Reserve holdings of greater than 50 million tons, as reported in Keystone Coal Industry Manual, McGraw-Hill, 1978.

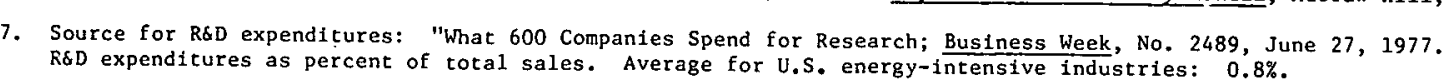

- Does not include feedstuck uses. 
(2) Although a Major Near-Term Market Is Not Expected For Single-User MBG, the Most Likely Early Adopters Are Expected to Be the Chemical, Steel and, Perhaps Aluminum Industries

1. The Chemical Industry Is the Most Likely Eariy Adopter for MBG

Several key factors point to chemicals as likely to adopt MBG before other industries, according to information gained from industry interviews :

The attractiveness of MBG gas'as feedstock", in that it eliminates the need for natural gas reforming, as well as fuel

Plant sizes and load factors are sufficient to support adequate gasifier utilization

The industry is increasingly using coal

Companies are familiar with gasification technology, or--at a minimum--expert with its chemical process nature

- The industry is regarded as highly innovative

- There are concentrations of the industry in attractive gasification locations, e.g., the Texas Gülf Coast.

MBG can be used widely throughout the chemical industry. The most attractive applications of MBG in the industry include:

Feedstock uses in commodity chemicals:

- Ammonia

- Methanol

- Acetic acid

- Fischer-Tropsch synthesis

- Ethylene glycol

- Thermal heat exchangers

- Process steam

- Power generation 
The most likely locations will be in the Texas Gulf Coast and several other states, as shown in Exhibit VII-8.

2. The Steel Industry Is Anticipated to Be Among the First to Use MBG

Several criteria indicate that steel will be among the early adopters of MBG, as shown previously in Exhibit VII-7.

- Plant sizc and load factor are aufficient to support high utilization of the gasifier

- Coal is already used extensively in sleel-ihakiny piviesses, ididiealiny llie availability of coal handling equipment

- The industry has major holdings of coal reserves and producing companies

- It is highly familiar with gasification, and plant use and distribution of lower'energy gas

- The industry is located in attractive potential gasification areas, including. Pennsylvania and ohio

- Certain processes; including heat treating and annealing; require gaseous fuels.

The most attractive applications of $M B G$ in the steel industry will include, as indicated in industry discussions:

- Coke oven firing

- Steel furnace firing

- Soaking pits

- Reheating

- Heat treating and annealing

- Boiler fuel.

The most likely locations of MBG in the steel industry are anticipated to be in Pennsylvania and ohio, with several other states also likely, as illustrated in Exhibit VII-8. 
EXHIBIT VII-8

Number of Industrial Plants

With Fosisil Fuel Consumption Above 7.4 Billion Btu/Day

Selected Industries, for.High Potential states

\begin{tabular}{|c|c|c|c|c|c|c|c|c|c|}
\hline & Paper & Chemicals & Petroleum & $\begin{array}{c}\text { G]ass } \\
\text { Containers }\end{array}$ & Cement & $\begin{array}{l}\text { Brick, } \\
\text { Clay Tile }\end{array}$ & Basic Steel & $\begin{array}{c}\text { Aluminum } \\
\text { Other } \\
\text {. Non-Ferrous }\end{array}$ & $\begin{array}{l}\text { Fabricated } \\
\text { Metal }\end{array}$ \\
\hline California & 2. & 5 & 10 & - & 8 & - & 1 & - &.- \\
\hline Colorado & - & - & - & - & - & - & 1 & - & - \\
\hline Kentucky & 1 & 2 & 1 & - & - & - & 1 & - & - \\
\hline North Dakota & - & $\because \quad-$ & 1 & - & $-\cdot$ & - & - & - & - \\
\hline Ohio & 4 & $\therefore 6$ & 3 & - & 2 & - & 11 & - & - \\
\hline Pennsylvania & 3 & . 3 & 3 & - & 2 & - & 17 & - & 1 \\
\hline Tennessee. & 2 & 9 & - & - & 2 & - & T & 1 & - \\
\hline Texas & 4. & 35 & 19 & - & 8 & - & 2 & 2 & - \\
\hline Wyoming & - & 3 & 4 & - & - & - & - & - & - \\
\hline Total & 16 & 63 & 41 & 0 & 22 & 0 & 30 & 3 & 1 \\
\hline
\end{tabular}

Source: Low-Btu Gas Industrial Applications Analysis, Work Papers, Systems Consultants, Inc., November 1978. 
3. The Aluminum Industry Is a Possible Early Adopter of MBG

Three factors indicate that the aluminum industry is a potential target for single-user medium-Btu gasification:

The industry's need for clean gaseous fuels in several non-electrolytic applications, e.g., heat treating and arnealing

- Aluminum's sensitivity to gas supply interruptions

- Its reputation as a major innovator in the use of energy.

Two factors, however, raise doubts about the industry's. likelihood to move ahead early on gasification:

- The industry's experience in coal handling and end-use is not extensive, although some companies do own coal reserves

- The number of plants with fossil fuel consumption large enough to support a feasibly sized gasifier is not large.

The most likely locations of MBG facilities in the industry would be in Texas and Ténnessee, as seen previously in Exhibit VII-8.

Major applications of medium-Btu gas:in the aluminum sector would include:

Melting

Heat treating and annealing

Power generation, to replace fuels now used for self-generation. 
4. Industries and Equipment Suppliers Also Identify the Chemicals and Primary Metals Industries As Most Likely to Adopt MBG

Industry executives and representatives of manufacturing and architect/engineering firms have reached conclusions that the chemicals and primary metal industries are the most likely early adopters. The chemical and primary metals industries were cited by interviewees more frequently than all other firms combined.

5. Other Major Energy-Consuming Industries Are Not Likely to Be Early Adopters of MBG in the Single-User Mode Due to Four Key Factors

The level of plant fuel consumption precludes practical applications of $M B G$ in three industries. Economic operation of a minimally sized MBG facility suggests that plant fossil fuel demands exceed at least 10 billion Btu/day, a level not generally met in the following industries:

- Food

- Textiles

- Brick and tile.

The lack of need for a clean gaseous fuel rules out most practical applications of MBG in two major industries. These industries, which consequently show little current interest in gasification, include:

- Cement, now heavily reliant on direct coal combustion

Paper, the nation's largest user of residual oil, a major coal user, and strongly dependent on forest wastes.

The lack of experience with coal is the key factor limiting gasification in two industries, glass and fabricated metal products:

Glass uses. little, if any, coal; often lacks any space for storage and handling facilities on plant sites 
Fabricated metals uses modest amounts of coal, has little ownership of coal properties.

A limited concern for fuel supply security is the majur factor reducing the petroleum industry's interest in gasification. Some oil firms view themselves as least likely to suffer from fuel supply interruptions, given the nature of their business.

(3) The Expected 1985 Market for Single-User MBG Is Not Anticlpated to Exceed Two or Three Newly Operating plants

The anticipated costs of $M B G$, relative to other fuels, now dissuades potential industrial users, including likely early adopters, from going ahead, on MBG gasification. The relative differences in costs are estimated to be, as follows:

- Industrial users typically anticipate MBG gas costs of $\$ 4.00$ to more than $\$ 7.00$ per million Btu, as. shown in Exhibit VII-9.

. The cost of MBG gas from a 20 billion Btu/day facility will generally fall in the $\$ 6.00$ to $\$ 6.50$ per milition Btu range, but may exceed $\$ 9.00$, as shown in Chapter III, Exhibit III15.

- Current delivered natural gas prices, as shown previousiy in Exhibit VII-5, range from $\$ 1.12$ to $\$ 3.32$, and fuel oil from $\$ 2.60$ to $\$ 3.95$.

Industrial users, including those in the chemical and steel industries, will not install medium-Btu gasiieation on other than strict economic grounds. Based un interview findings, most industrial enatnmera wil.1 continue to make fuel choices on a direct comparison of dollars per million Btu, given the near-term outlook for adequatè fuel supplies.

In the chemical and primary metals industries, less than 20 percent of those interviewed indicated any willingness to pay a premium for secure supplies. 
EXHIBIT VII-9

Quoted Fuel Costs and. Perceived Gasification Costs

( $\$$ per MMBtu)

\begin{tabular}{|c|c|c|c|c|}
\hline & \multicolumn{4}{|c|}{ Potential Industrial Users } \\
\hline Industry & Natural Gas & $\begin{array}{l}\text { Fuel } 0 i 1 \\
\text { or Other. }\end{array}$ & $\begin{array}{l}\text { Low-Btu } \\
\text { Gas }\end{array}$ & $\begin{array}{c}\text { Medium-Btu } \\
\text { Gas }\end{array}$ \\
\hline Chemicals & $1.50-.2 .25$ & $2.00-2.25$ & 4.35 & $3.50-4.00$ \\
\hline Petroleum & $2.00-2.25$ & - & $5.00-10.00$ & $4.00-10.00$ \\
\hline Cement & 2.25 & $0.84-1.36^{*}$ & 3.00 & - \\
\hline $\begin{array}{l}\text { Brick \& } \\
\text { Refractories }\end{array}$ & $2.05-2.80$ & - & $3.00-3.40^{\prime}$ & - \\
\hline Glass & 2.40 & - & - & 5.00 \\
\hline $\begin{array}{l}\text { Primary } \\
\text { Metals }\end{array}$ & $2.00-2.20$ & $1.90-1.95$ & $2.50-3.00$ & $4.00-12.00$ \\
\hline $\begin{array}{l}\text { Metal Fab. } \\
\text { \& Autos }\end{array}$ & 2.00 & - & $2.50-6.50$ & $4.00-6.00$ \\
\hline Other & $1.75-2.60$ & $2.00-2.60$ & 3.50 & - \\
\hline
\end{tabular}

* Coal.

Source: Industry Interviews, Based on Early 1979 and 1978 Data. 
The chemical, steel, and possibly aluminum industries are, according to the industry-specific early adoption criteria shown in Exhibit VII-6, the most likely candidates for near-term adoption of MBG. Within these industries, the expected candidates for early adoption can be further narrowed by an additional set of company-specific criteria. The expected MBG target firms within these industries must be characterized by each of the following:

- Available capital for gasifier and oxygen plant

- A reliable long-term source of coal supplies

- Coal handling facilities at plant target sites

- Available site space for gasifier, clean-up train, and oxygen plant

- An environmentally acceptable location.

Other company-specific characteristics that are likely to be associated with, although not necessary to, a decision to adopt MBG include:

Prior experience with gasification

Captive coal supplies

Adequate water resources.

The firms most likely to begin installation of a single-user MBG facility by 1985 will also be characterized by a highly unique, and still further limiting, set of circumstances, such as one of the following situations :

A company with an available source of oxygen, eliminating the major capital costs of constructing an oxygen plant. The source can, perhaps, be an existing plant of an over-thefence supplier with uncommitted oxygen production.

- A large company anticipating major energy supply problems, and interested in installing an initial plant, to gain operating experience, or because of a particularly attractive financial arrangement. 
Discussions with equipment suppliers, A\&E firms, and potential industrial users showed little "hard" interest in installing $\mathrm{MBG}$ :

- No significant MBG plants operational

- No pilot applications underway

- Only two' current, extremely specialized MBG feedstock applications, using available oxygen and coke, with outputs of only about 0.7 billion Btu/day

- No MBG facilities under construction

- No MBG single-user plants known to be in the engineering and design phase

- No MBG construction plans submitted to senior managements or boards for approval.

The preceding analysis indicates that even in industries for which early adoption is most attractive, single-user $M B G$ is at best marginally economic. The 1985 market is forecast, as shown in Exhibit VII-10, to include a small number of innovators in unusually attractive situations:

- 2 or 3 MBG plants total

- Most likely in the chemical, steel, or possibly aluminum industries

- Probably located in the ohio River Valley or in the Gulf Coast area.

(4) There Are Five Major Barriers to Near-Term Market Penetration By Single-User MBG, But the Most Important Is That Its Costs Are Unfavorable

Several key concerns are inhibiting industrial acceptance of MBG gasification. Illustrative comments of industrial energy users are shown in Exhibit VII-11, and analyzed in the following sections. 
EXHIBIT. VII-10

Expected Near-Term Market

For Single-User MBG

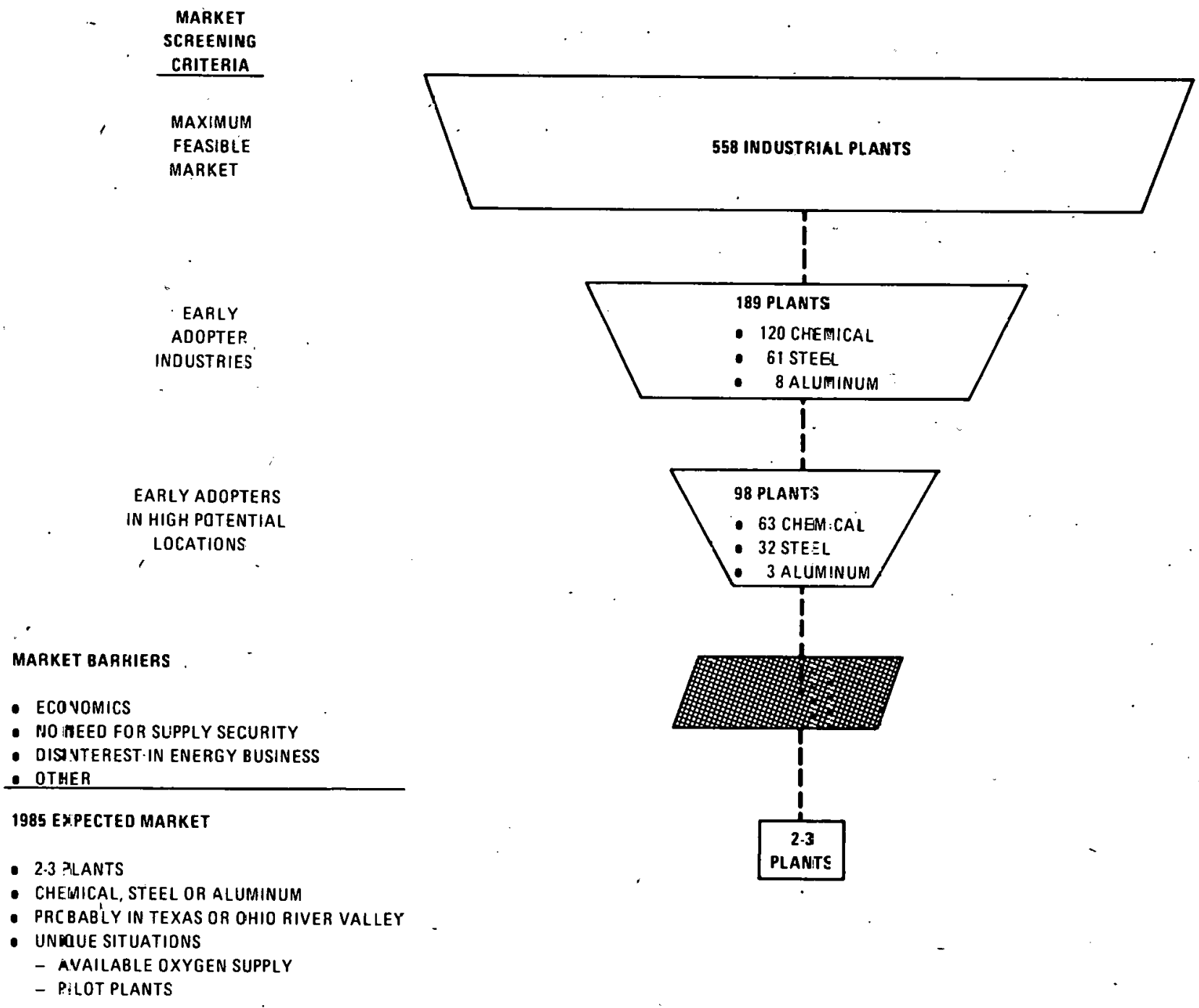




\section{EXHIBIT VII-II \\ Industry Comments on Market Barriers To Gasification}

\begin{tabular}{|c|c|c|c|c|}
\hline & Price Non-Competitive & $\begin{array}{c}\text { Not Concerned With Supply } \\
\text { Security }\end{array}$ & $\begin{array}{c}\text { Disinterest in Utility } \\
\text { Business }\end{array}$ & Otherı \\
\hline $\begin{array}{c}\because \\
\text { Low-8tu }\end{array}$ & $\begin{array}{l}\text {. Metal fabricatiitg company } \\
\text { is highly interested in } \\
\text { gasification but sees LBG } \\
\text { as too costly vs. alterna- } \\
\text { tive natural gas. Company } \\
\text { indicated situation would } \\
\text { still hold in } 1980 \text { s. } \\
\text {. Brick company, with inajor } \\
\text { supply problems would } \\
\text { prefer LBG for technical } \\
\text { quality but will likely } \\
\text { move to direct coal com- } \\
\text { bustion because of much } \\
\text { cheaper costs. }\end{array}$ & $\begin{array}{l}\text { Petroleum company sees self } \\
\text { as "last company to suffer" } \\
\text { from a supply shortfall. } \\
\text { due to its energy holdings } \\
\text { and the nature of its } \\
\text { business. } \\
\text {. Company recently installing } \\
\text { LBG due to supply problems } \\
\text { now sees no prob! ems until } \\
\text { the 1990s. Would now want } \\
\text { project to "stand on its } \\
\text { own two feet" economically. }\end{array}$ & $\begin{array}{l}\text { Glass producer does not } \\
\text { envision itself in the } \\
\text { energy business and does } \\
\text { not have related technical } \\
\text { expertise. Would prefer } \\
\text { an over-the-fence supplier } \\
\text { to handle all the details. } \\
\text {. Paper company would be } \\
\text { attracted to LBG if price } \\
\text { were colipetitive, but it } \\
\text { has no desire to spend } \\
\text { investment funds in a busi- } \\
\text { ness outside of its own } \\
\text { line. }\end{array}$ & $\begin{array}{l}\text { Cement company would con- } \\
\text { sider LBG only if it happened } \\
\text { to be sitting on top of a pile } \\
\text { of high-sulfur coal difficult } \\
\text { to clean. Company also sees } \\
\text { lack of cement-proven technol- } \\
\text { ogy as an impediment. } \\
\text {.Metal fabricating company sees } \\
\text { major problems with cleanliness } \\
\text { of LBG, corrosion, and retrofit } \\
\text { requirements. it also calls } \\
\text { solid waste disposal poten- } \\
\text { tially a "nightmare." }\end{array}$ \\
\hline $\begin{array}{l}\text { Medium-Btu, } \\
\text { Single User }\end{array}$ & $\begin{array}{l}\text {.Large steel company made } \\
\text { study of HBG for major } \\
\text { plant, found costs far in } \\
\text { excess of al ternatives, } \\
\text { about S5 per million Btu's. } \\
\text {. Chemical company has } \\
\text { studied MBG in depth, but } \\
\text { believes that the "econom- } \\
\text { ics of MBG are still many } \\
\text { years from being in the } \\
\text { ball park," and has no } \\
\text { plans at this time. }\end{array}$ & $\begin{array}{l}\text { - Large chemical company } \\
\text { "will pay next to, nothing" } \\
\text { for supply security. Be- } \\
\text { lieves that if one supply } \\
\text { source dries up, can easily } \\
\text { turn elsewhere. } \\
\text {. Major steel company has } \\
\text { made plant-specific studies } \\
\text { of MGB, but does not be- } \\
\text { lieve that high fuel supply } \\
\text { security is needed. Com- } \\
\text { pany believes. it can always } \\
\text { buy oil, and if it can't, } \\
\text { then its customers can't } \\
\text { either--in which case it } \\
\text { won't need oil anyway. }\end{array}$ & $\begin{array}{l}\text { Major steel company sees } \\
\text { potential for MBG appli- } \\
\text { cations, but is not in- } \\
\text { terested in operating its } \\
\text { own facility. It would } \\
\text { rather avoid the "hassles" } \\
\text { of the business, and put } \\
\text { the risk on the supplier's } \\
\text { back. } \\
\text { Chemical company has eval- } \\
\text { uated use of MBG in one } \\
\text { of its facilities, but } \\
\text { doubts that it will operate } \\
\text { a gasifier before 19g0. } \\
\text { But, it would much rather } \\
\text { purchase its supplies from } \\
\text { a utility tran produce its. } \\
\text { own gas. }\end{array}$ & $\begin{array}{l}\text { Steel company has studied ail } \\
\text { major processes, and finds } \\
\text { none ideally suitable. It } \\
\text { believes a lack of demonstrated } \\
\text { reliability is a major obstacle } \\
\text { - Large petroleum company would } \\
\text { choose gasification as the } \\
\text { last energy alternative in its } \\
\text { operations, due largely to the } \\
\text { availability of by-product } \\
\text { fuels. They would also even } \\
\text { prefer direct coal combustion } \\
\text { and possibly electricity, on } \\
\text { economic grounds. }\end{array}$ \\
\hline $\begin{array}{l}\text { Mediun-Btu, } \\
\text { Multiple Users }\end{array}$ & $\begin{array}{l}\text {.Large chemical company has } \\
\text { investigated MBG exten- } \\
\text { sively, including multiple- } \\
\text { user facility, but finds } \\
\text { that costs are still not } \\
\text { competitive with oil and } \\
\text { gas. } \\
\text { Major steel company has } \\
\text { concluded that energy from } \\
\text { gasification is consider- } \\
\text { ably more expensive than } \\
\text { that currently available } \\
\text { from internally produced } \\
\text { sources, from direct burn- } \\
\text { ing of coal, and from oil } \\
\text { and gas. }\end{array}$ & $\begin{array}{l}\text { - Hetal fabricating company } \\
\text { "would prefer multi-user } \\
\text { facility, but cannot see } \\
\text { any way it could consider } \\
\text { it before the early l990s, } \\
\text { particularly with its gas } \\
\text { utility delivering all the } \\
\text { gas they can utilize, even } \\
\text { during previous shutdown } \\
\text { period. } \\
\text { Glass company was potential } \\
\text { participant in multiple- } \\
\text { user facility, but has had } \\
\text { no major curtailment prob- } \\
\text { lems in past few years, and } \\
\text { is entirely willing to } \\
\text { de, send on current gas } \\
\text { suppliers. }\end{array}$ & $\begin{array}{l}\text { Glass company has investi- } \\
\text { gated the possiblity of } \\
\text { joint ventures with utili- } \\
\text { ties, but has made the } \\
\text { decision not to go into } \\
\text { the energy business as part } \\
\text { of its ongoing operations. } \\
\text {. Chemical company is highly } \\
\text { interested in feedstock } \\
\text { use of MBG and believes } \\
\text { that multi-user configura- } \\
\text { tion is most likely, but } \\
\text { is held back by preference } \\
\text { to avoid entry into utility. } \\
\text { or energy business. }\end{array}$ & $\begin{array}{l}\text { Petroleum company with large } \\
\text { interests in multiple-user } \\
\text { concept believes that what } \\
\text { is needed now more than any- } \\
\text { thing else "is a good operating } \\
\text { facility complete from coal } \\
\text { production to delivery to } \\
\text { cus tomer use," so problems can } \\
\text { be worked out of the overall } \\
\text { operation. } \\
\text { Metal fabricating company } \\
\text { interested in multi-user MBG } \\
\text { believes that federal energy } \\
\text { price regulations, and.con- } \\
\text { flicting policy signals, are } \\
\text { a major market deterrent. }\end{array}$ \\
\hline
\end{tabular}


1. High Costs of Single-User MBG

According to estimates developed in previous sections, the cost of gas from a 20 billion Btu/ day plant ranges from about $\$ 4.30$ to $\$ 9.30$ per million Btu. Discussions with potential users generally corroborated these estimates, with most anticipating costs per million Btu of $\$ 5.00$ to $\$ 6.00$, exclusive of retrofit costs, as shown previously in Exhibit VII-9.

The prices of natural gas, however, were generally quoted in interviews to lie in the $\$ 2.00$ to $\$ 2.25$ range early this year, rising to perhaps $\S 3-\xi 4$ per million Btu by the middle 1980's (1979 dollars). Number 2 fuel oil is currently priced in the $\$ 3.60$ to $\$ 3.95$ range, as shown in Exhibit VII-5; future prices are highly uncertain. Based on present fuel prices, $M B G$ single-user gas is anywhere from 10 percent to over 100 percent more expensive.

Less than 15 percent of companies interviewed would be willing to pay any premium above the cost of competitive fuels to ensure secure energy supplies. Even these firms' willingness to pay a premium would largely depend on confidence in the gasifier's reliability, business conditions, and other factors. Industry participants suggested a premium of 5 to 10 percent as typical.

\section{Lack of Concern Over Energy Supplies}

Many industrial have installed--in the wake Qf natural gas curtailments and the OPEC oil embargo-duel fuel capabilities that make them less vulnerable to supply interruptions.

Qther companies are willing to pay the added costs of propane, or other back-up fuel, on a temporary basis. However, most companies interviewed" do not envision major shortfalls in gas supplies in the near future. It should be noted,. however, that the current instability in world energy markets makes this perception highly subject to change. 
3. Disinterest in Producing Captive Energy:

Industry discussions revealed a significant disinterest in the difficulties involved in owning/operating an MBG gasifier and indicated.strong preference for an over-the-fence supplier. This general pattern was due both to company strategic planning considerations, and to competing demands for funds from production investments.

\section{Risk of Unproven Technology}

Although there is substantial foreign experience with gasification, and historic and limited contemporary experience domestically, little detailed information is currently available on actual industrial applications. The risk of a technology that is largely untested and unknown in major U.S. Industrial applications is a key deterrent cited in a large number of interviews.

The lack of U.S. experience in medium-Btu applications precludes many industries from enjoying a high degree of confidence in either the reliability of gasification or the use of MBG in specific industrial processes.

\section{Effects of Federal Regulations}

Numerous companies cited the unpredictable or often contradictory nature of federal energy and environmental regulations as being major barriers to MBG penetration, due to the increased risk in new energy investments, and reduced incentive to shift to new technologies if energy prices are controlled.

Another regulatory issue cited in some interviews as requiring further exploration was the disposal of ash and slag wastes. 
3. IT IS UNLIKELY THAT ANY MULTIPLE-USER MEDIUM-BTU GAS IFICATION FACILITIES WILL BE OPERATIONAL OR UNDER CONSTRUCTION BY 19:85:

The early adoption criteria developed above for the single-user MBG market can; for the most part, apply to potential multiple-user MBG applications; and the industryby-industry assessment of likely single-user markets can, therefore, be referenced for the multiple-user configuration. However, major differences in the two markets are evident:

- Because customers of a multiple-user facility are not constrained by any minimum size requirement, the number of potential end-users is' greater than for single-user plants.

- The larger scale of multiple-user plants raises an additional set of issues clouding the prospects for MBG plants, including:

- Necessary project lead times
- Expected MBG costs
- Need for an MBG "patron."

(1) The Lead Time Required for Bringing On Line a Major MBG Facility Rules Out Any Installations By 1985 .

Examination of the lead time rcquircd to conetruat similar-scaled energy facilities indicate that the necessary lead time. for project arrangement and construction of a major MBG facility (greater than 100 billion Btu/day) would realistically place initial operation into at least the late $1980^{\prime} \mathrm{s}$, if started in 1979. As shown in Exhibit VII-12, typical timeframes run from 2 to more than 12 years for other major eneryy facilities.

Discugsions with industrial users also indicated that necessary lead time requirements would in all likelihood place MBG into at least. the latter 1980's, especially in light of the time needed to arrange an MBG consortium. Interviewees generally suggested a minimum of 5 or 6 years as the likely lead time for even a smaller, single-user facility. 
EXHIBIT VII-12

Typical Lead-Time Requirements

For Major Energy Fácilities

\section{PROJECT}

1. ELECTRIC POWER PLANTS

NUCLEAR

COAL

BASE LOAD. OIL

GAS TURBINE

2. OIL REFINERY

3. COAL LIQUEFACTION

$$
\Delta
$$
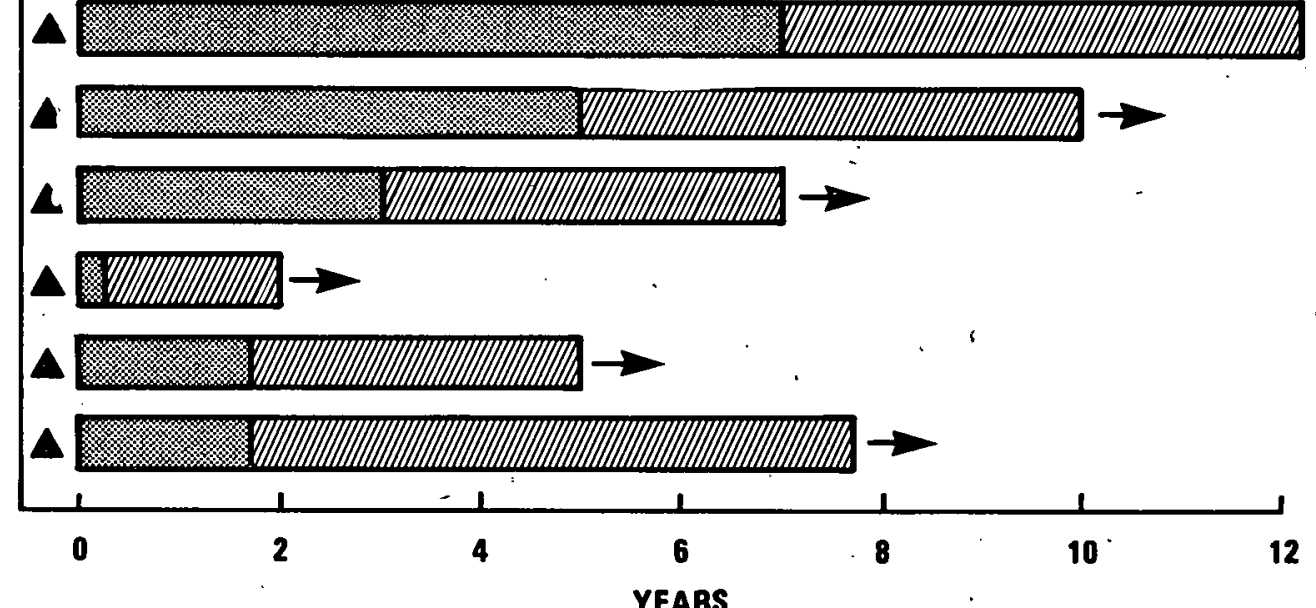

KEY:

- COMPANY PROJECT AUthorization

APPROVALS, PERMITTING AND PRE-ENGINEERING

CONSTRUCTION

CÓMMERCIAL OPERATION 
The East Texas Project, a 300 billion Btu/day MBG facility proposed by Carter oil Company, now underway for more than 4 years, does not expect to produce any gas until the early 1990's. The first of two construction modules of the centralized lignite-fed plant is now anticipated to begin in 1985 or 1986.

\section{'. (2) The Cost of Gas Supplied From a Multiple-User MBG Plant Is Expected to Be competitive only Under the Most Favorable of Circumstances}

The costs of medium-Btu gas, exclusive of retrofit, from a major gasification facility are estimated (Chapter III, Exhibit III-13) at a minimum of $\$ 3.00$ per million Btu, assuming utility-type financing and low coal costs. More likely (Base Case) estimates place the gas costs at $\$ 3.96$, which is above the costs of competing fuels.

Under industrial-type financing, gas costs are, under the most favorable assumptions, estimated at $\$ 3.59$, exclusive of retrofit. The most likely estimates are $\$ 5.08$ per million Btu and less favorable assumptions place gas costs at $\$ 6.68$ per million Btu.

Estimates of potential industrial users themselves generally fall in the $\$ 4$ to $\$ 7$ range, although several cited figures well above that range, as shown previously in Exhibit VII-9. Rapidly escalating fuel prices of recent months, however, make price comparisons subject to significant uncertainty. If the price trends of recent months continue much into the future, multipleuser MBG plants coulä become fully competitive with alternative fuels on a dollar per million Btu basis.

The Lack of a. "Patron" Among the Four Kinds of Potential Owners of MBG Significantly Hinders the Development of the Multiple-User Market

Four kinds of companies, or groups of companies, are potential owners of a multiple-user MBG facility, each with a somewhat different interest in investing in such a facility. The four kinds, of owners include:

Coal or natural resource producer, interested in expanding markets for its coal 
- Gas utility, either a pipeline or distribution company, interested in supplementing its existing gas supplies

- Independent financial venture, organized to take advantage of a potentialiy attractive investment opportunity

- Joint venture of potential industrial users, interested in ensuring secure fuel supplies.

An examination of the strategic factors surrounding investment in an MBG facility, as shown in Exhibit VII-13, indicates that no clear winner emerges from among the potential owners of a multiple-user plant. As a result, $M B$ in the multiple-user mode lacks a real patron, a critical success factor in the market penetration of emerging technologies.

The near-term outlook for investment in multipleuser MBG facilities is clouded in particular by three factors:

- Uncertainty in the prices of alternative energy sources, due to unpredictable oil cartel pricing actions and to unclear federal energy policies. Because of the difficulty in forecasting competitive fuel prices, the risk of investment in MBG facilities increases substantially. This factor is critical for all four potential market entrants.

- Potential exposure to the regulated utility environment is a major deterrent to investment in MBG facilities for all but gas utility entrants, which are already regulated. Industrial companies interviewed repeatedly cited disinterest in the regulated utility business as an important consideration in their decision not to: pursue a joint venture arrangement.

- Lack of related expertise poses a further barrier to investment in multiple-user MBG. Successful operation of such a facility requires expertise in coal handling, energy conversion $\%$ and end-use delivery, a combination of characteristics possessed by none of the four potential owner groups. 


\begin{tabular}{|c|c|c|c|c|}
\hline $\begin{array}{l}\text { POTENTIAL OWNER } \\
\text { OR INVESTOR }\end{array}$ & INVESTMENT RATIONALE & ADVANTAGES & DISADVANTAGES & OUTLOOK \\
\hline $\begin{array}{l}\text { COAL PRODUCER OR } \\
\text { NATURAL RESOURCE COMPANY }\end{array}$ & $\begin{array}{l}\text { Expand existing markets } \\
\text { for coal }\end{array}$ & $\begin{array}{l}\text { - Opens up markets for industrial users of } \\
\text { other fuels, feedstocks, to coal } \\
\text { - Diversifies energy-related interests, thus } \\
\text { reducing vulnerability to shifts in coal } \\
\text { market } \\
\text { - Capitalizes on coal handling experience } \\
\text { - Offers opportunity to integrate forward in } \\
\text { energy industry }\end{array}$ & $\begin{array}{l}\text { - Requires high investment cost for MBG facility } \\
\text { - Brings company into area of major state } \\
\text { utility regulation } \\
\text { - Must add expertise in unfamiliar fuel delivery } \\
\text { systems } \\
\text { - Exposes company to uncertainties of demand } \\
\text { for, and price of, gas }\end{array}$ & $\begin{array}{l}\text { - Near-term investment most likely of four } \\
\text { Owner alternatives, but still cloudy } \\
\text { - Carter Oil's East Texas Project nearing } \\
\text { decision stage, but may be under } \\
\text { construction by } 1985 \\
\text { - Key Factors: Regulatory environment, } \\
\text { uncertain energy prices }\end{array}$ \\
\hline $\begin{array}{l}\text { GAS UTILITY } \\
\text { (Pipeline or } \\
\text { Distribution } \\
\text { Company) } \\
\end{array}$ & $\begin{array}{l}\text { Supplement present } \\
\text { natural gas supplies }\end{array}$ & \begin{tabular}{|l} 
- Offers natural fit with major business of \\
delivering gaseous fuel \\
- Permits maintaining current industrial users, \\
while freeing up natural gas for home heating \\
market \\
- Offers potentially most attractive financial \\
arrangement \\
- Poses fewest regulatory problems, since \\
companies now regulated
\end{tabular} & $\begin{array}{l}\text { - Must add expertise in coal handling } \\
\text { - Requires major capital investment } \\
\text { - May cannibalize some natural gas sales; make } \\
\text { company more dependent on seasonal home } \\
\text { heating market } \\
\text { - Financing terms heavily dependent on } \\
\text { regulatory environment }\end{array}$ & $\begin{array}{l}\text { - Near-term MBG plant unlikely in near-term } \\
\text { - Implementation of Natural Gas Policy Act } \\
\text { poses major uncertainties, reduces } \\
\text { likelihood of investment } \\
\text { - Key Factors: Lack of expertise in coal } \\
\text { area, state and Federal energy regulations }\end{array}$ \\
\hline $\begin{array}{l}\text { INDEPENDENT FINANCIAL } \\
\text { VENTURE } \\
\text { (Over-the-Fence Supplier) }\end{array}$ & $\begin{array}{l}\text { Offers potentially } \\
\text { attractive return on } \\
\text { investment }\end{array}$ & $\begin{array}{l}\text { - Utilizes venture's access to capital markets } \\
\text { - offers ground-floor opportunity in emerging } \\
\text { energy technology }\end{array}$ & $\begin{array}{l}\text { - Exposes investors to high-risk venture } \\
\text { - Requires acquisition of coal handling, energy } \\
\text { conversion experience } \\
\text { - Requires energy supply and delivery expertise } \\
\text { - Exposes venture to state utility regulation }\end{array}$ & $\begin{array}{l}\text { - MBG investment is least likely of four } \\
\text { - N1ternatives } \\
\text { consajor projects now under significant } \\
\text { - Key Factors: Lack of related expertise, } \\
\text { high-risk exposure }\end{array}$ \\
\hline $\begin{array}{l}\text { JOINT VENTURE OF } \\
\text { INDUSTRIAL USERS }\end{array}$ & $\begin{array}{l}\text { - Enhances fuel supply } \\
\text { security }\end{array}$ & $\begin{array}{l}\text { - Offers self-protection against șupply } \\
\text { interruption } \\
\text { - Permits individual users to reap advantage } \\
\text { of large plant scale economies } \\
\text { - Offers benefits of gasification, but without } \\
\text { problems of. coal handling, plant space, and } \\
\text { cleanup }\end{array}$ & $\begin{array}{l}\text { - Involves high financing costs, due to } \\
\text { potential risk } \\
\text { - Requires addition of expertise in coal- } \\
\text { handling, fuel delivery } \\
\text { - Introduces companies into regulated business } \\
\text { - Competes for available funds with production } \\
\text { investments }\end{array}$ & $\begin{array}{l}\text { - MBG facility unlikely in near-term } \\
\text { - No user appears, willing to take the lead on } \\
\text { a facility, although many are willing to } \\
\text { come on board afterwards } \\
\text { - Key Factors: High costs, exposure to } \\
\text { utility regulation }\end{array}$ \\
\hline
\end{tabular}


This chapter has analyzed the expected near-term industrial market for 10 - and medium-Btu gasification, and has examined the major barriers to further penetration of this market. The next chapter addresses the government's role in accelerating the penetration of LBG and MBG in the industrial sector. 
VIII. GOVERNMENT ROLE IN ACCELERATING INDUSTRIAL MARKETS FOR

LOW- AND MEDIUM-BTU GASIFICATION 


\section{GOVERNMENT ROLE IN ACCELERATING INDUSTRIAL MARKETS FOR LOW-: AND MEDIUM-BTU GASIFICATION}

Preceding chapters have addressed the status of technology and economics, current market activities, market potential and the expected market for 1985. This chapter takes account of these findings and considers how government can effectively accelerate industry's acceptance of IBG and MBG. The assessment is presented in four parts:

- Overview of present federal initiatives

- Estimated impact of present federal. initiatives onindustrial markets

- Definition of problems to be overcome

- Recommendations from the industrial marketplace on additional federal initiatives.

1. CURRENT FEDERAL INITIATIVES WHICH WILL IMPACT LBG/MBG MARKETS INCLUDE' DOE PROGRAMS, ECONOMIC INCENTIVES AND A VARIETY OF REGULATIONS

DOE initiated a program in mid-1976 to demonstrate the atilization of low-Btu gas in industrial applications. A total of six projects were undertaken. with partial government funding... At the time of this report, one project is operating, one project has been cancelled and the remaining four projects are in various stages of engineering, construction, and start-up (see chapter IV).

In 1978, DOE selected LBG/MBG as one of 20 technologies for commercialization. Subsequently, a Program Interest Notice (PIN) was released to industry. At the time of this report, responses are being reviewed for potential program action.

In addition to.-DOE activity, legislation has been enacted since 1978 which will enhance. the market growth opportunity for low- and medium-Btu gasification: Key legislation is as follows: 
- Direct incentive: The Energy Tax Act of 1978 provides for a 10 percent investment tax credit, over and above the standard 10 percent industrial investment tax credit, for alternative energy property, including coal gasifier equipment and nonboiler burners for alternate fuels

- Fuel use regulation: The "Powerplant and Industrial Fuel Use Act of 1978" prohibits the use of oil or natural gas in new industrial boilers with. a fuel heat input of 100 million Btu's per hour or greater; and may extend prohibition on using natural gas in existing MFI boilers after 1990

- Fuel price deregulation: The "Natural Gas Policy Act of 1978" provides for deregulation of certain natural gas leading to complete deregulation by January 1, 1985. In addition, the Act provides for incremental pricing to industrial users as a means of protecting residential and other users from cost impacts. Natural gas prices to industry are anticipated to increase before 1985 to just marginally less than fuel oil prices. Further oil price deregulation between now and the early 1980's as presently anticipated will impact industrial fuel use trends.

2. IMPACT OF EXISTING FEDERAL INITIATIVES IS INADEQUATE TO STIMULATE A SUBSTANTIAL INDUSTRIAL MARKET FOR LBG/ MBG BY 1985

our findings from industry interviews indicate that the 1976 "Gasifiers in Industry" Program was highly regarded by industry, considered an excellent idea, and now considered of little value due to delays and complexities of the government program. The remaining federal initiatives are not anticipated to have impact on the 1985 market for a variety of reasons as discussed in the following sections.

(1) Thipdist of the Prebent DOE Program to Date Is Negligible

Based on findings from interviews conducted for the study, industry considers previous federal programs to have been a deterrent, rather than enhancer, of LBG/MBG market growth, for several reasons: 


\section{Verification from studies that LBG and MBG are not economically viable, while providing no initiatives to correct the cost problems \\ : Confirmation of the "red tape" delays to undertake a gasifier, project with government involvement \\ - Perceived lack of action to resolve environ- mental uncertainties and conflicts between DOE and EPA policy.}

(2). Impact of the Powerplant and Industrial Fuel Use Act of 1978. Will Be Fuel Switching to Other Conventional Fuels

Fuel use regulations are targeted to new, largescale boilers, which do not generally require a clean or gaseous fuel (see chapter V). For this reason, LBG/MBG is not the fuel of first choice. Where environmental regulations restrain direct coal firing, LBG/MBG plants compete with the cost of flue gas desulfurization and other clean-up. The comparison is not economically attractive for LBG/MBG, since in such a situation, gasification would also include gas cleanup equipment.

(3) : Impact of Fuel Price Deregulation Is Anticipated to Be Significant After 1985

As discussed in Chapter II, future fuel price increases are anticipated. However, the extent and rate of increase for each fuel price is exceedingly uncertain. More important, the relative price movements between fuels is difficult to predict, including:

The extent to which coal prices follow oil prices, or break away to be based on supply/. demand relationships

- The extent of incremental natural gas pricing to industry, and the rate of fuel oil price increases which represent approximate ceiling levels for natural gás prices. 
There is, however, universal attention in industry that IBG, MBG and other technology alternatives will be increasingly attractive. Economic viability might be achieved in the 1980 's. At that point, industry will move toward LBG/MBG resulting in operating plants in the 1990 timeframe.

(4) Taken Together, Current Federal Initiatives Are Anticipated to Enhance Longer-Term Prospects for LBG/MBG. However, They Are Inadequate to Stimulate Near-Term Action by Industry to Have Gastiers Operating By 1985

Analysis in r.hapter II sonsluded that industry is in a "wait and see" mode at the time of this report. With six years experience in building capabilities to deal with the energy situation, industry is holding major long-term investment for three factors:

- Regulation of fuel price trends

- Federal energy vs. environmental policy trends

- Improved operating data on gasifiers.

In addition to deferral of major energy investments, there are a number of specific barriers to LBG/ MBG market penetration, as discussed in the following section.

3. INDUSTRY IS WELL INFORMED ON COAL GASIFICATION AND HAS CONCLUDED THAT IT IS NOT ECONOMIC, THAT IT DOES NOT SOLVE AN URGENT PROBLEM, AND THAT THERE IS INADEQUATE SUPPORTING DATA TO BUILD CONFIDENCE IN POSSIBLE OPPORTUNITIES

Tlit luost oumpelling indication of induotry's vicwpoint on LBG and MBG is a sample of actual findings from interviews with: knowledgeable'individuals. Appendix C presents company comments on:

- Expected action with regard to LBG/MBG

- Reasons underlying present decisions. 
Major conclusions from these findings are as follows:

- Nearly all large corporations which are potential users have studied LBG/ MBG and are knowledgeable on technical and economic characteristics

- The vast majority have reached firm conclusions that LBG/MBG is not economic at this time (one company represented LBG/MBG as "proven beyond a shadow of a doubt" by DOE to be uneconomic)

- Industry does not view LBG/MBG as a solution to urgent present problems of cost or supply security

- Industry does not have persuasive or compelling data to support DOE or equipment supplier claims of potential opportunities

- While conventional fuel supplies are not entirely secure, industry has greater confidence in its ability to deal with fuel problems than technology problems :

- Fuel suppliers and utilities have performance track records. Poor future performance is a risk

- More significant, gasification technology has a limited worldwide track record, and an extremely limited U.S. track record. Equipment performance is more than a risk; it represents to industry an uncertainty

- The period of anticipated attractiveness for LBG and MBG has slipped another five years, to the late 1980's and beyond, due to economics and natural gas availability (studies in the early/ mid-1970's predicted attractiveness in the early $1980^{\prime}$ s).

4. A BASIC PROGRAM OF INCENTIVES, OPERATIONAL DEMONSTRATIONS, AND APPIICATION STUDIES WILI BE RESPONSIVE TO MARKET NEEDS AND SHOULD ACCELERATE THE LBE/MBG MARKET SIGNIF ICANTLY

The industrial market for LBG and MBG is being stopped by several basic and fundamental barriers, which can to varying degrees be overcome directly by government initiatives. 
There presently exists a wide range of federal involvement in the areas of industrial energy supply and utilization, as shown in Exhibit VIII-l. Based on the marketplace view of barriers to be overcome, there are four key recommendations from potential ụsers (see Exhibit VIII-2 for company recommendations):

- Economic incentives to early adopters

- Demonstration program

- Special studies of retrofit requirements

- Resolution of environmental uncertainties.

Each area of potential federal initiative is discussed in the following sections.

(1) LBG and MBG Are Economically Comparable to the Cost of Other Marginal Fuel Supplies. Financial Incentives Would Be Most Effective If Offered As a Portfolio of options to Meet Different situations

Industry is adamant that little or no investment action will take place without clear economic rationale. As stated by an industrial marketing expert, there are four specific components of the rationale:

- Current economic advantage

- Demonstration if an overriding set nf favorable long-term esonomios (on tho ordor of ton years, including 3 to 5 years. for planning, engineering and construction, plus 3 to 5 years to achieve payback)

- Minimal or manaqeable risk

- Urgency: reason to act now.

Results of the interviews and economic analysis (Chapter III) show clearly that IBG/MBG gasification does not provide àn attractive opportunity when compared to no action (status quo).

There exists a reasonable public policy justification for government incentives. Both LBG and MBG are economically comparable to the cost of other marginal energy sources, as shown in Exhibit VIII-3, on a $\$ / M M B t u$ basis. 
EXHIBIT VIII-1

Several Levels of Government Involvement Are Available To Achieve the Commercialization of Coal Gasification

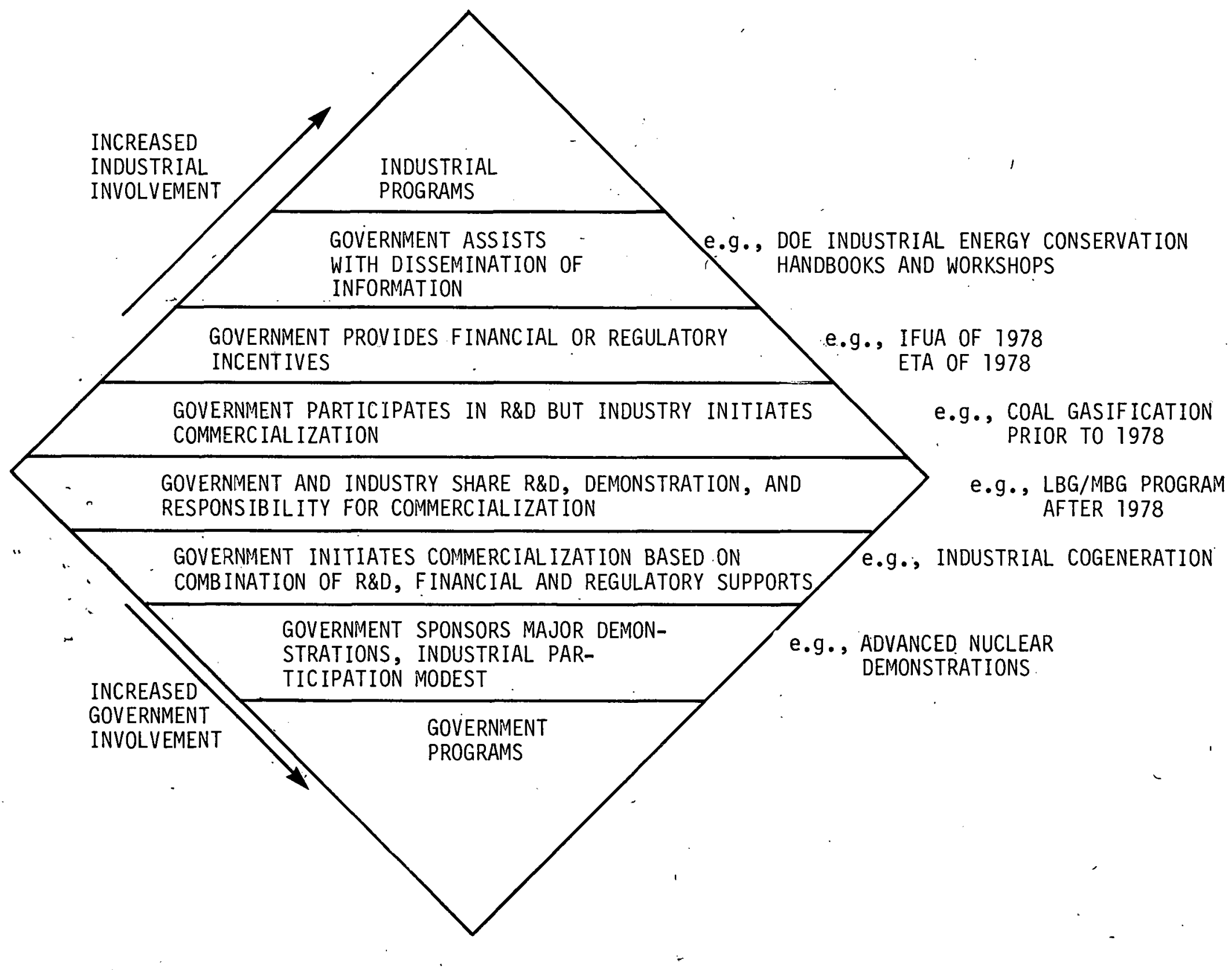


EXHIBIT VIII-2

Industry Recommendations for Federal Government Actions to Spur MBG/LBG

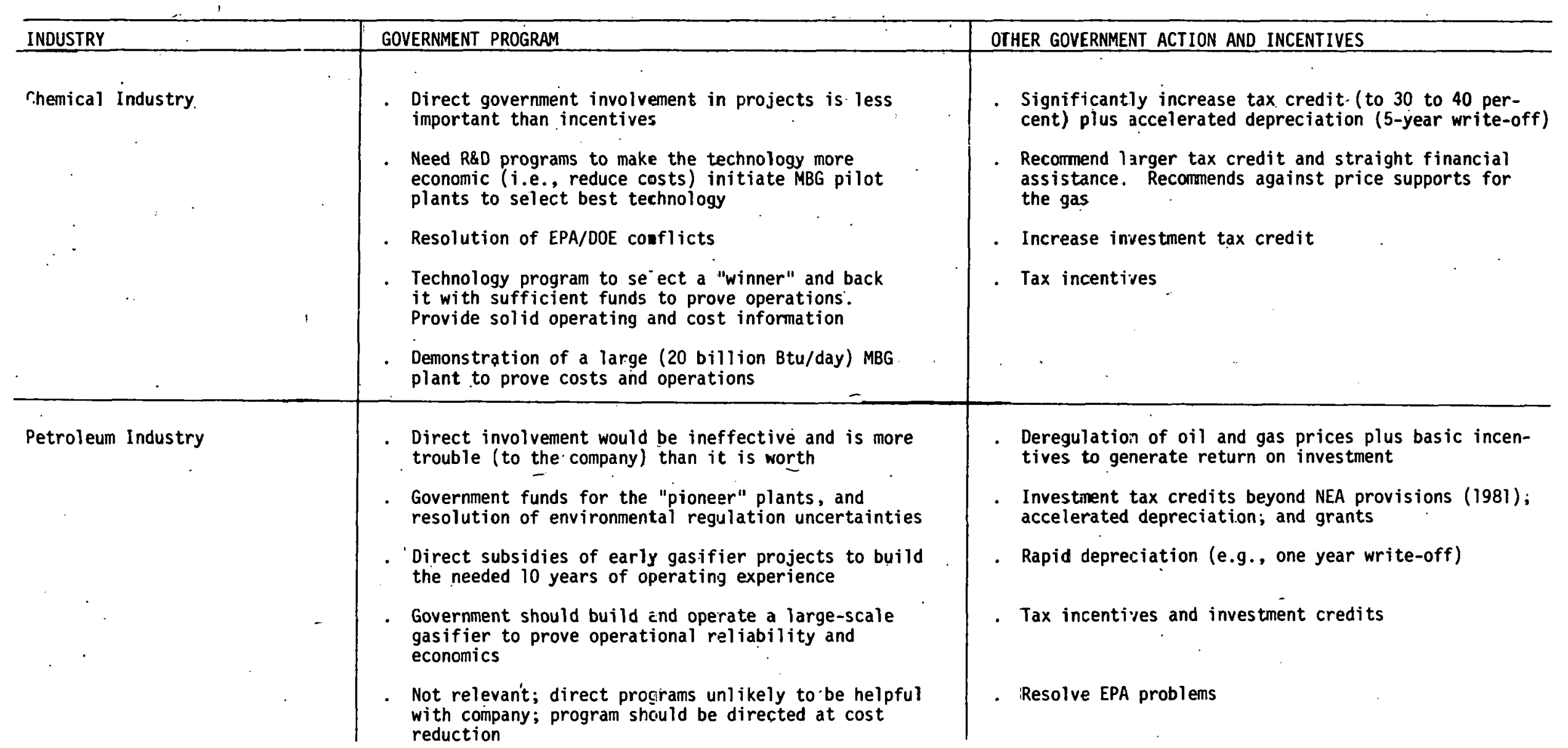




\section{EXHIBIT VIII-2 \\ (Cont nued)}

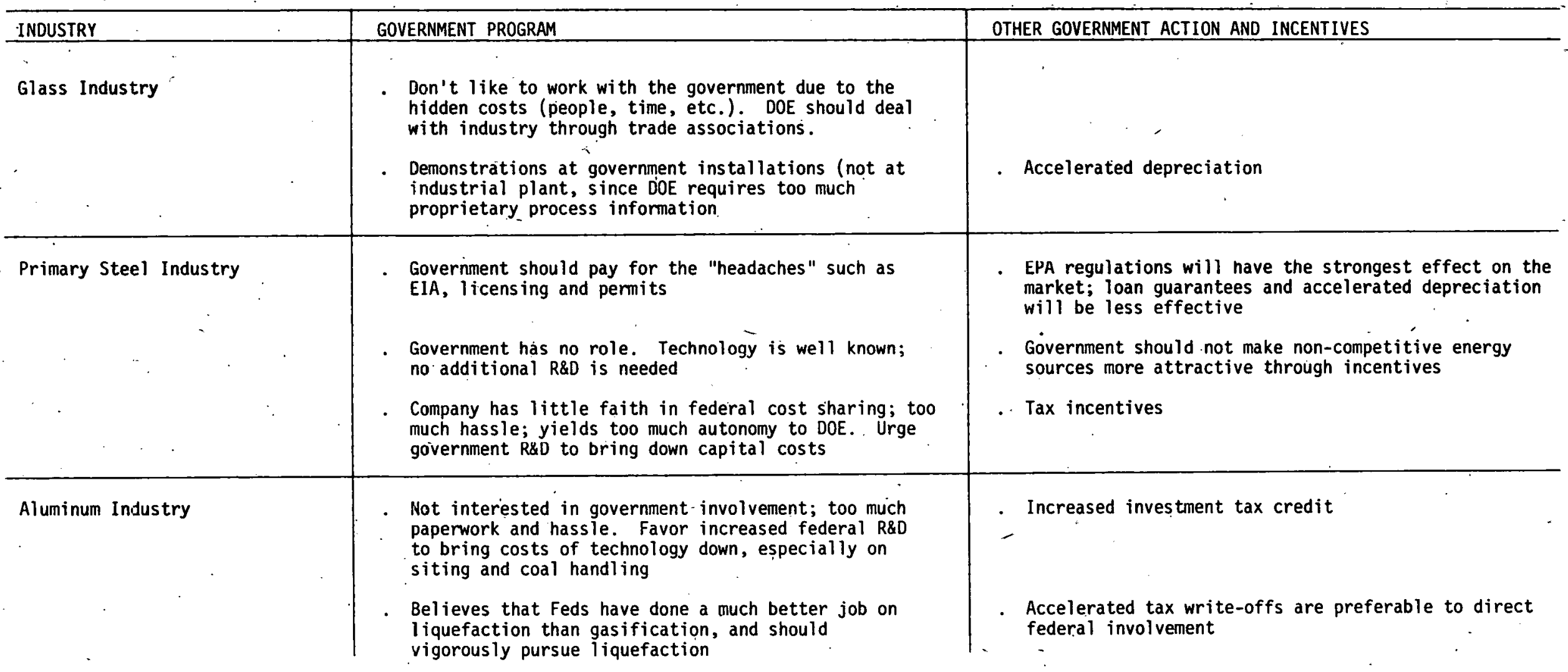




\section{EXHIBIT VIII-2}

(Continued)

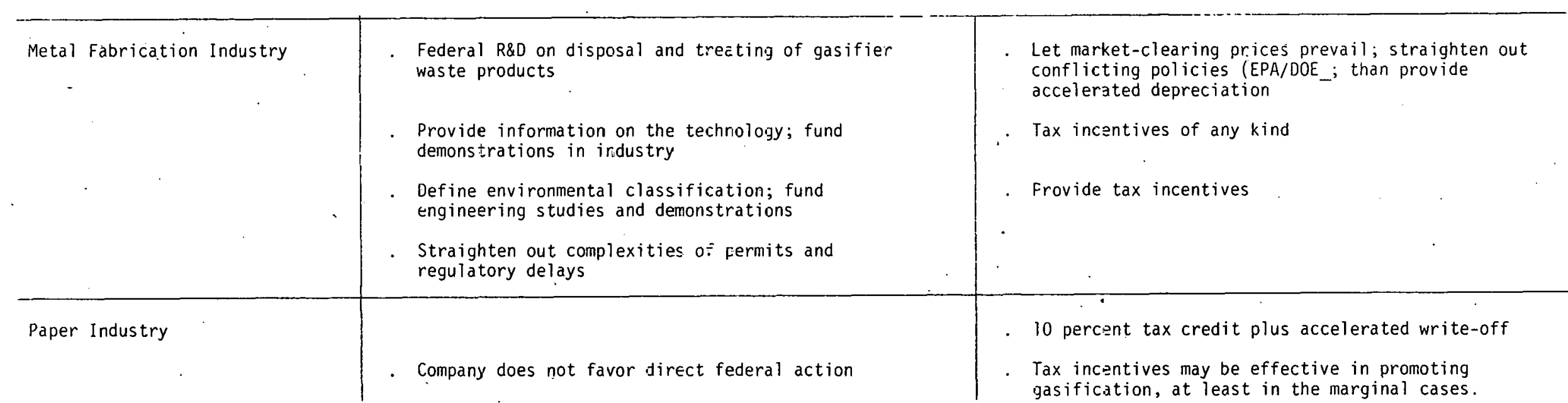

\begin{tabular}{l|l|l}
\hline Cement Industry & $\begin{array}{l}\text { Fear "time and trouble" loss by dealing with } \\
\text { federal government } \\
\text { Federal assistance is unl ikely to help }\end{array}$ & $\begin{array}{l}\text { Tax incentives } \\
30 \text { percent tax credit plus accelerated depreciation } \\
\text { (3-year write-off) }\end{array}$ \\
\hline Brick Industry & $\begin{array}{l}\text { Direct participation with the federal government } \\
\text { is not worth the trouble to the company. Govern- } \\
\text { ment funds should go into proving the technology. }\end{array}$ & $\vdots$
\end{tabular}


EXHIBIT VIII-3

Single Source Comparison of Cost Estimates for Selected Energy Supply Technologies

Liquid Fuels

- Enhanced Oil Recovery (EOR)

$2.07-3.94$

- Coal Liquefaction (1990 costs)

$3.60-4.60$

- Oil Shale

$2.50-5.00$

Gaseous Fuels

. Enhanced Gas Recovery (EGR)

$1.50-3.00$

3.83

- Liquefied. Natural Gas (LNG)

$2.80-3.90$

Medium-Btu Gasification (MBG)

$$
4.60
$$

- High-Btu Gasification (HBG)

$4.00-4.30$

Other

- Urban Waste

- Solar, Agriculture/Industry

- Solar Hot Water

Source: Overview of Technology Commercialization Assessment, U.S.. Department of Energy, November 1978. 
Identifying the most effective incentive is less a problem of economic theory than one of providing incentives to which the industrial marketplace will actually respond. Determining likely response depends upon the degree to which all of industry is surveyed, since each industry and company operates in a unique business, financial, tax, and regulatory situation.

Companies interviewed for the study showed preference for least-red tape incentives:

. Tax credits--equipment or production

- Rapid tax write-off.

However, depending upon unique situations, com- . panies might be just as likely to respond to other incentives. The fundamenlal valiatiuns 1 n companyspecific situations argues for a multi-incentive approach which includes tax benefits and other options from which early adopters can select. Other options include:

- Low cost capital

\section{- Loan guarantees \\ - Direct loans}

- Direct subsidies (percent cost sharing)

- Performance insurance for early adopters

- Regulatory exemptions.

It is beyond the scope of the study to analyze incentive approaches in detail: However, the basic message is clear--from direct investigation of industry activity--that little market results will be achieved without strong economic rationale.

(2) Demonstrations Are Needed to Build Experience in U.S. Operating Environments and to Build the Confidence of Decisionmakers on Government Treatment

The need for demónstrations cannot be proven empirically.: However; the consistency of industry concern for lack of operating experience in the U.S. environment is a strong indication that demonstrations will precede'substantial commercial plant decisions. 
A major finding from the interviews is that government decisionmakers sometimes fail to understand the need for demonstrations. There are two reasons for LBG/MBG demonstrations expressed by industry:

- To develop operating and cost data from credible sources (to a large segment of industry; credible source is synonymous with U.S. sources).

- To determine how various government agencies-federal and state--will. treat the technology in terms of environmental control, health, safety, etc.

(3) Plant-Specific Studies Are Needed to Define Retrofit Requirements and Costs

The question of industrial plant retrofit requirements and costs can be traced back to reports into the early 1970's. However, industry's view is that the questions stand, without factual answers. Extensive data search for this study resulted in no factual retrofit data. Findings from interviews indicate three compelling reasons for DOE funding of plant-specific engineering studies :

- Lack of factual data is deferring decisions-which follow from confidence that decisions are correct

- Engineering studies are costly: Industry will not fund studies unless the basic LBG/MBG technology appears economically attractive

- While retrofit is plant-specific, a substantial degree of informational benefit will accrue to all companies within each industry.

(4) Environmental Regulation Uncertainties Need to Be Resolved

EPA has not defined new source performance standards for LBG/MBG gasifiers. Further, the extent of. enforcement--or, conversely, revision--of the clean Air Act on direct coal burning is uncertain. 
Based on interviews conducted for the study, industry is "gun shy" to adopt a new energy technology until government regulatory policies are clear.

(5) Based on our Best Judgment and Findings From Interviews, a Package Program of Incentives, Demonstrations, Retrofit Studies and EPA/DOE Policy Resolution Should Substantially Accelerate the LBG/MBG Market

The study was not:based on modeling or other nathematical simulation of industry investment action. For this reason, it is not possible to theorize on the "probable". market"size given federal action.

On a more practical level, analysis of interview findings indicates strongly that the market will respond to economic rationality and low risk.

The basic, underlying potential for LBG/MBG is large (Chapter $\mathrm{V}$ ). Given federal action to address specific practical problems (previous sections), we anticipate LBG/MBG investment levels to accelerate.

- At this time, a substantial market- that is, beyond "early adopters"--is not considered lijkely until at least the late 1980's or early $1990^{\prime} \mathrm{s}$

- With incentives and program action, the basic market movement might be accelerated by several years.

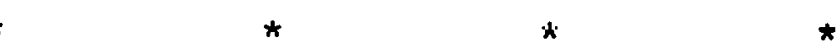

This chapter has presented assessment of current federal initiatives affecting $L B G$ and $M B G$, concluded that they will have little impact on the expected 1985 market, assessed the key barriers to market penetration, and communicated four recommendations from industry on the need for federal action. 


\section{APPENDIX A}

PARTICIPANTS IN INTERVIEWS 


\section{APPENDIX A \\ PARTICIPANTS IN INTERVIEWS}

1. CURRENT AND PROSPECTIVE USERS

(1) Brick and Refractories

General Refractories Co.

H. L. Becker

50 Monument Road

Bala Cynwyd, PA 19004

Glen Gery Corp.

227 North Fifth Street

Reading, PA 19601

Hazleton Brick Co.

Hazleton, PA $18201^{\prime}$

R. W. Dammann

P. Morone

(2) Cement

National Lime \& stone Co.

James withrow

P.O. Box 120

Findlày, OH 45850

(3) Chemicals

Chemical Exchange Co.

3813 Buffalo Speedway

J. Eggert

:Houston, TX 77098

Dow Chemical Co.

C.C. Armstrong,

2030 Dow Center

Midland, MI 48640

Gulf \& Western Titanium

(New Jersey Zinc Division)

2426 Middle Road

Ashtabula, OH 44004

olin chemical corp.

Middle Road

Ashtabula, OH 44004

Robert Suttman 
(4) Metal Fabrication And Automobiles

General Motors Corp.

General Motors Technical Center

Warren, MI 48090

Holston Defense Corp.

Holston Army Ammunition Plant

Kingsport, TN 37662

(5) Primary Metals

Howmet Aluminum

(Subsidiary of Pechiney

Ugine Kuhlmann)

475 Steamboat Road

Greenwich, CT 06830

(6) Other

Land O'Lakes, Inc.

614 Mckinley Place

Minneapolis, MN 55413

Pikeville Coal Gasification Project

Pikeville, KY 41501

U.S. Bureau of Mines

Minneapolis, MN 55413

University of Minnesota

319 15th Avenue, S.E.

Minneapolis, MN 55413
Richard Teno

Paul Shaffer

Johnny Potts
Dave A.' Boyles

Bernard A. Gaffney

G. Eckert

John Nigro

.

J. Roback

W. Soderberg'

2. POTENTIAL INDUSTRIAL USERS

(1) Brick and Refractories

Acme Brick Co.

2821 West 7 th street

Lavid Brack

Ft. Worth, TX 76101

Brick Institute of America

1750 old Meadow Road

McLean, VA 22101

Richard Thomas 
Exolon Co.

1000 E. Niagara Street

Tonawanda, NY

General Shale Products Corp.

P.O. BOx 3547 , CRS

Johnson City, TN 37601

A.P. Green Refractories Co. (Subsidiary of US Gypsium Co.)

Green Boulevard

Mexico, MO 65265

Metropolitan Industries, Inc.

2185 Boliver Road, S.W.

Canton, OH 44706

National Gypsum Co.

4100 First Int'l Bldg.

Dallas, TX 75270

Redford Brick Co.

.12th \& Maury Street

Richmond, VA 23224

Sioux City Brick \& Tile Co.

222 Commerce Bldg.

Sioux City; IA 51102

(2) Cement

Ideal Basic Industries

950 17th Street

Denver, CO 80201

Martin-Marietta

6801 Rocklege Drive

Bethesda, MD 20034

(3) Chemicals

Aix Products \& Chemicals

P.O. Box 538

Allentown, PA 18105

Del Laboratories, Inc.

565 Broadhollow Road

Farmingdale, NY 11735
Arthur Gerbec

Joseph Edwards

F.M. Maupin

Peter McCallin

E.J. Sommerfelt

William Edwards

John Hill

Parnell H. Mahoney

Fred Bauer

Norman Maycock

William Amos

David Marcus 


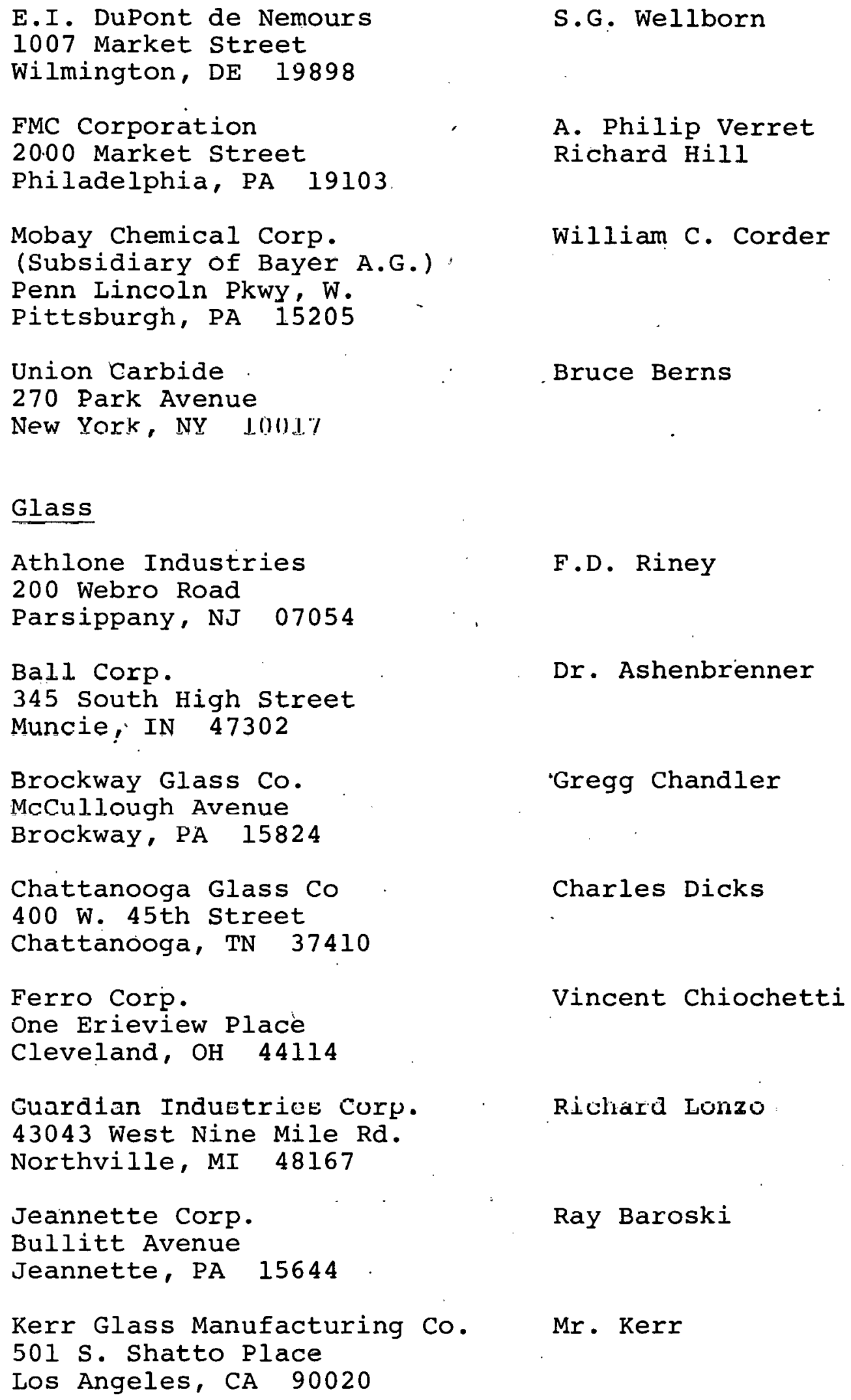

Athlone Industries

200 Webro Road

Parsippany, NJ 07054

Ball Corp.

345 South High street

Muncie; IN 47302

Brockway Glass Co.

McCullough Avenue

Brockway, PA 15824

Chattanooga Glass Co

400 W. 45 th street

Chattanooga, TN 37410

Ferro Corp.

One Erieview Place

Cleveland, OH 44114

Guardian Induetries Curp.

43043 West Nine Mile Rd.

Northville, MI 48167

Jeannette Corp.

Bullitt Avenue

Jeannette, PA 15644

Kerr Glass Manufacturing Co. Mr. Kerr

501 S. Shatto Place

Los Angeles, CA 90020

F.D. Riney

Dr. Ashenbrenner

‘Gregg Chandler

Charles Dicks

Vincent Chiochetti

Richard Lonzo

Ray Baroski

(4) Glass 
Midland Glass Co., Inc. Cliffwood Avenue

Cliffwood, NJ 07721

Owens-Illinois, Inc.

405 Madison Avenue

Toledo, $\mathrm{OH} 43666$

PPG Industries, Inc.

One Gateway Center

Pittsburgh, PA 15222

Susquehanna Corp.

$3600 \mathrm{~S}$. Yosemite street

Denver; CO 80237

(5) Metal Fabrication

American Can Co.

American Lane

Greenwich, CT 06830

American Seating Co.

901 Broadway, N.W.

Grand Rapids, MI 49504

Cameron Iron Works

P.O. Box 1212

Houston, TX 77001

Haussy Metals

Lettsdale, PA

Ingalls Iron \& Steel

Sheffield, AL

Mansfield Carbon Products

Nashville, TN 37204

Midrex

(Subsidiary of Korf Industries)

One NCNB Place

Charloote, NC 28280

Pascoe Steel

(Subsidiary of Amcord Industries)

1301 E. Lexington Avenue

Pomona, CA 91766
M. Burchmore

Herman Kummerle

Robert H. Steder

J.T. Worko
Ronald Shavalier

Jack Kiefer

Maurice Steel

Frank Murray

Robert scott

Ronald Enzweiler 
(6) Petroleum

Ashland Oil

P.O. Box 391

Claude $\mathrm{H}$. Messinger

Ashland, KY 41101

Carter Oil Co.

(Subsidiary of Exxon)

P.O. Box 2180

Houston, TX 77001

John Racz

A.B. Grady

H.R. Irvine

Shell oil Co.

R.B. Breckenfeld

One Shell Place

Houston, TX 77001

Standasd Oil co. or Indiana

200 E. Randolph Street

-

Chicago, IL 60601

Tennessee Gas Pipeline Co.

(Subsidiary of Tenneco)

1100 Milam Building

Houston, TX 77001

Union oil co.

Union Oil Center

Los Angeles, CA 90017

Al Eliskalns

Jack Rafuse

(7) Primary Metals

Armco, Inc.

703 Curtis street

Middletown, OH 45043

Roy Miller

George White

Inland steel corp.

$30 \mathrm{~W}$. Monroe Street,

Henry Miller

Jerry Curtis

Chicago, IL 60603

Robert wilsun

Kaiser Aluminum \& Chemical Co. . 300 Lakeside Drive

Oakland, CA 94643

Edward Boobyer

Kaiser steel Co.

300 Lakeside Drive

Richard :Póol

Oakland, CA 94643

William Smith

Lukens Steel Co.

Jeff Smith

50 S. First Avenue

Coatesville, PA 19320 
U.S. Steel Corp.

125 Jamison Lane

Monroeville, PA 15146

(8)

Other

Johnson \& Johnson

501 George St.

New Brunswick, NJ 08903

Mead Paper Co.

Courthouse Place, N.E.

Dayton, $\mathrm{OH} 45463$

St. Regis Paper Co.

150 E. 42nd Street

New York, NY 10017
W.W. Campbell

James R. Guseman

Marshall Molloy

Ralph Bernstein

James Starkweather

3. MANUFACTURERS AND ARCHITECTS/ENGINEEERS

American Lurgi Corp.

377 Route 17

Hasbrouck Heights, NJ 07604

Applied Technology Corp.

P.O. Box 27125

Houston, TX 77027

Combustion Engineering

1000 Prospect Hill Road

Windsor, CT 06095

Davy Powergas, Inc.

6161 Savoy Drive

Houston, TX 77036

Gas Generation Associates

510 Park Road North

Wyomissing, PA 19610

Gilbert Associates, Inc.

P.O. Box 1498

Reading, PA 19603

Koppers Company, Inc:

Koppers Bldg.

Pittsburgh, PA 15219
Ted Pollaert

G.E. Brewer

James E. Byers

Fred E. Dorst

Robert Patterson

Edgar E. Bailey

Rolf Maurer

James T. Stewart

James Bumbaugh

John Kamody 
Texaco Development Corp. 2000 Westchester Avenue

White Plains, NY 10650

Wilputte Corp.

152 Floral Avenue

Murray Hill, NJ 07974
E.T. Child

George R. Cooper 
APPENDIX B

THE GASIFIER EQUIPMENT INDUSTRY 


\section{APPENDIX B}

THE COAL GASIFIER INDUSTRY IS IN AN EMERGING STATE, AND THUS BUSINESS PRACTICES ARE HIGHLY FLUID

Five of the twelve commercial processes were developed in, the U.S.:

- Three (Wellman-Galusha, Wilputte and Riley-Morgan) are small capacity fixed bed gasifiers, derived from the old producer gas plants

- Two are new large entrained flow gasifiers (Texaco and Combustion Engineering) nearing commercialization.

The remaining seven processes were either developed in England, South Africa or Germany. All seven processes are available from U.S. licensees.

Coal gasification is for practical purposes an emerging industry in the U.S. Little is left from the producer gas systems of the $1920^{\prime} \mathrm{s}$ but design know-how and operations of small, fixed bed, single stage gasifiers.' In large scale gasification, whether by fixed bed, fluid bed or entrained flow, there is no historical U.S. experience. This results in a lack of real knowledge on several key aspects of large scale gasification, namely,

- The impact of U.S. coals, particularly eastern coals, on first generation gasifier performance

- Overall system reliability

- Maintenance requirements and costs

- The economic performance in the wide variety of applications and configurations.

In small-scale low-Btu coal gasification systems--where there is some experience on reliable processes--there is limited knowledge on the wide range of costs associated with retrofitting existing equipment.

A brief introduction to the gasification industry should begin with its actual and potential constitution. Stakeholders in this new industry consist of:

- Process developers,

- U.S. licensees of foreign processes 
- A/E firms willing to engineer and construct gasification plants

- Coal operators and brokers

- Equipment manufacturers, and

- Potentially, gas utilities.

Only the first three categories have so far committed resources to coal gasification. The services being presently offered by process developers, U.S. Licensees and A/L firms to the potential users of commercial coal gasification processes fall into several categories:

. Frocess developcra or liccncce provides one of the following

- Process design, leaving engineering and construction to other companies

- Turnkey installation based on this process

- Turnkey installation on any process, if acceptable to the other process developer or licensee.

- Architectural/Engineering firm provides one of

- Turnkey instal1ation on any process

- Turnkey installation on any process, but specializes in one

- Turnkey installation on any process and in addition operates, maintains and sells the gas at an agreed price to the user.

Exhibit B-I identifies U.S. process developers and licensees of other processes. 
EXHIBIT $B+1$

Commercial Gasifiers: Suppliers and Service Provided to the U.S. Market

\begin{tabular}{|c|c|c|}
\hline $\begin{array}{l}\text { Gasifier } \\
\text { Lurgi }\end{array}$ & Developer & $\begin{array}{l}\quad \frac{\text { U.S. License }}{\text { American Lurgi Corporation }} \\
377 \text { Route } 17 \\
\text { Hasbrouck Heights, NJ } 07604\end{array}$ \\
\hline Wellman-Galusha & $\begin{array}{l}\text { McDowell-Wellman Co. } \\
113 \text { St. Calir. Avenue, NW } \\
\text { Cleveland, OH } 44114\end{array}$ & $\begin{array}{l}\text { Dravo Corporation } \\
\text { One Oliver Plaza } \\
\text { Pittsburgh, PA } 15222\end{array}$ \\
\hline Wilputte & $\begin{array}{l}\text { Wilputte Corporation } \\
152 \text { Floral Avenue. } \\
\text { Murray Hill, NJ } 07974\end{array}$ & . \\
\hline Wel 1man-Incandescent & & $\begin{array}{l}\text { Applied Technology Corporation } \\
4242 \text { Southwest Freeway } \\
\text { Houston, TX } 77027\end{array}$ \\
\hline Riley-Morgan & $\begin{array}{l}\text { Riley Stoker Corporation } \\
\text { Worcester, MA }\end{array}$ & \\
\hline Stoic & & $\begin{array}{l}\text { Foster-Wheeler Energy Corporation } \\
110 \text { South Orange Avenue } \\
\text { Livingston, NJ } 07039\end{array}$ \\
\hline Wooda l1-Duckam/GI & & $\begin{array}{l}\text { Babcock Contractoirs, Inc. } \\
200 \text { Manor Oak Avenue } \\
\text { Pittsburgh, PA } 15220\end{array}$ \\
\hline Pullman-Swindell/IFE & & $\begin{array}{l}\text { Pullman-Swindell } \\
441 \text { Smithfield Street } \\
\text { Pittsburgh, PA } 15222\end{array}$ \\
\hline Winkler & & $\begin{array}{l}\text { Davy-Powergas, Inc. } \\
\text { P.0. Box } 36444 \\
\text { Houston, TX } 77036\end{array}$ \\
\hline $\begin{array}{l}\text { Koppers-Totzek } \\
\text { Koppers-Kerpely }\end{array}$ & & $\begin{array}{l}\text { Koppers Company, Inc. } \\
\text { Koppers Building } \\
\text { Pittsburgh, PA } 15219\end{array}$ \\
\hline Texaco & $\begin{array}{l}\text { Texaco Development Corp. } \\
2000 \text { West Chester Avenue } \\
\text { White Plans, NY } 10650\end{array}$ & \\
\hline Combustion Engineering & $\begin{array}{l}\text { Combustion Engineering } \\
1000 \text { Prospect Hil1 Road } \\
\text { Windsor, CT } 06035\end{array}$ & \\
\hline
\end{tabular}


APPENDIX C

FUEL SUPPLY HISTORIES BY STATE 
APPENDIX C

This appendix contains the fact sheets prepared for the analysis of the impacted areas of natural gas curtailments and a list of the data sources used to prepare them.

The five dot points in each cell of the fact sheets contain the following information where available:

- Percent and/or volume of industrial curtailments and ranking, if in top 20 states affected

- Percent and/or volume of alternate fuel shortfall and ranking, if. in the top 10 states affected

- Employment impact of gas shortages and affected industries

- Curtailed pipelines serving the state, percent curtailed, and ranking, if in the top 20 pipelines affected

- Special problems (e.g., fuel distribution problem, colder than normal weather). 


\section{Data Sources}

"1976-1977 Heating Season Projected Natural Gas Curtailments and Potential Needs for Additional. Alternate Fuels," November 1976, Federal Energy Administration

"1977-1978 Heating Season Projected Natural Gas Curtailments and Potential Needs for Additional Alternate Fuels," November 1977, U.S. Department of Energy, Energy Information

Administration.

"The Economic Impact of Gas Shortages," January 1978, Booz, Allen \& Hamilton Inc.

"Natural Gas Deliveries, Curtailment, and Alternate Fuel Offsets of Curtailment, April 1974 Through March 1977 Actual and April 1977 Through March 1978 Projected," May 1978, Federal Energy Regulatory Commission, Office of Pipeline and Producer Regulation.

"Impact of 1978-1978 Winter Curtailment för Twenty-Nine Pipeline Companies," September 1978, Federal Energy Regulatory Administration.

"Natural Gas Deliveries and Curtailments to Find-Use Customers and Potential Needs for Additional Alternate Fuels 1978-1979 Heating Season (November-March)," December 1978, U.S. Department of Energy, tnergy information Administration. 


\section{STATE NATURAL GAS AND ALTERNATE}

FUEL AVAILABILITY PROBLEMS

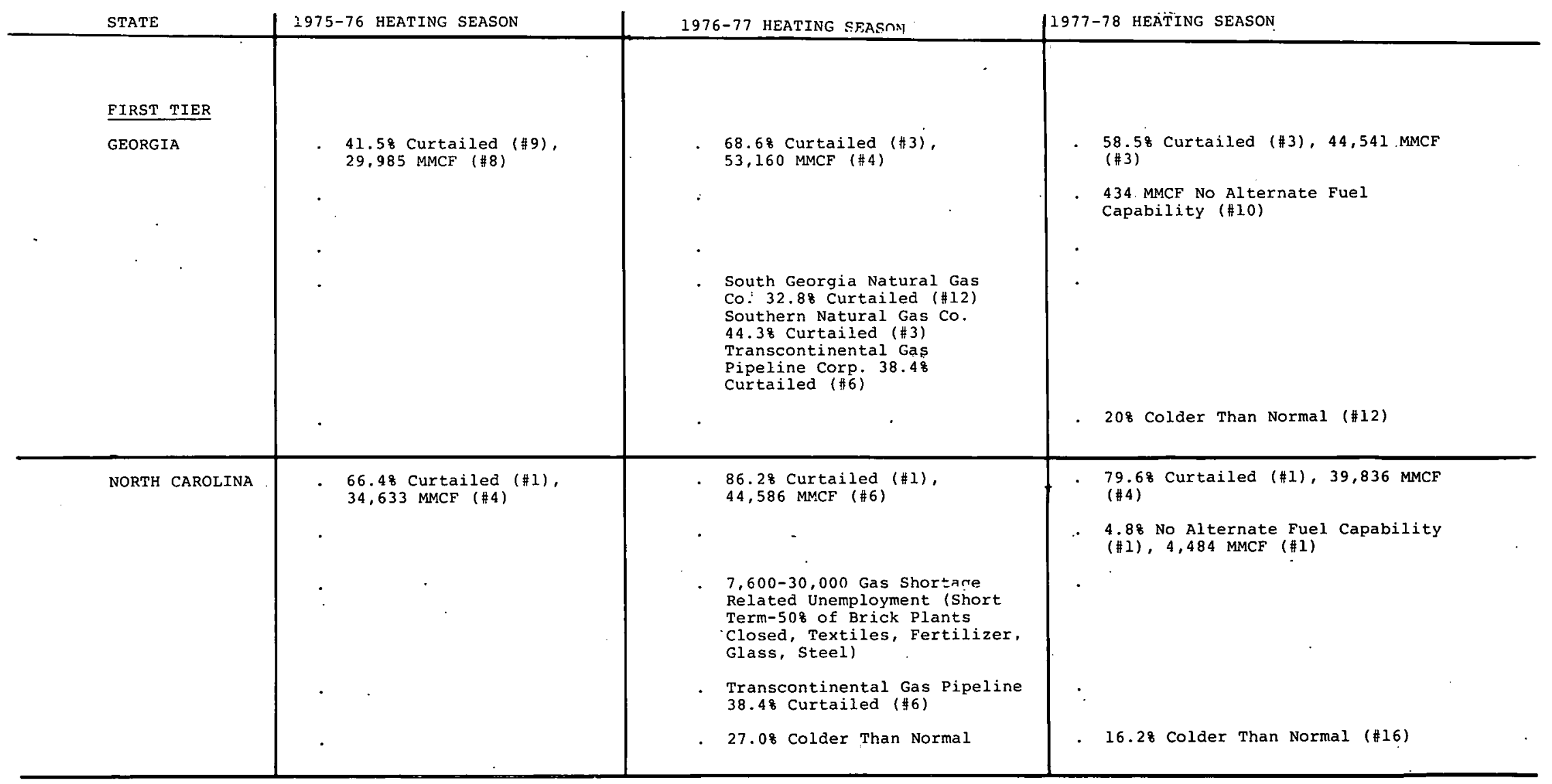




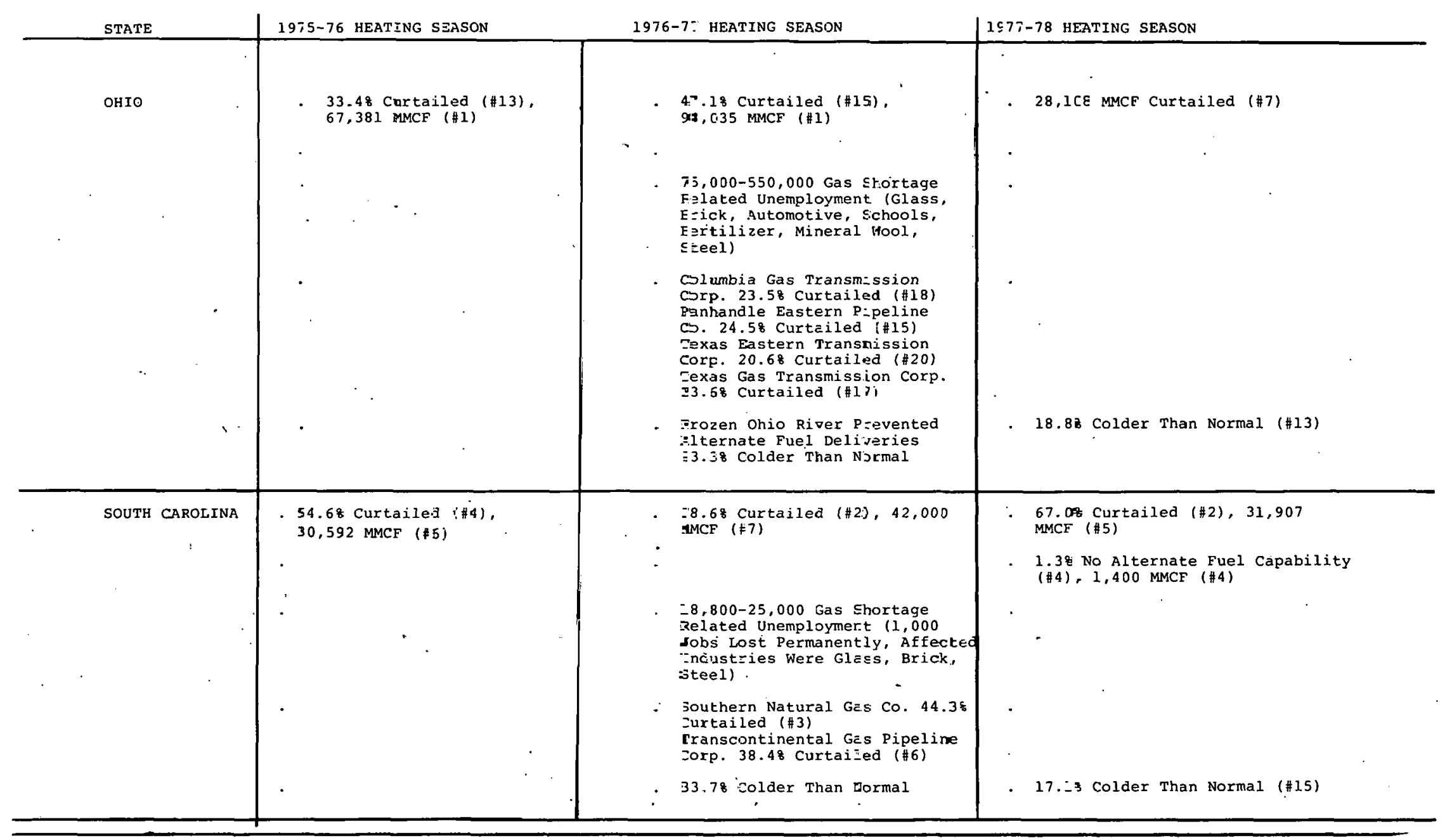




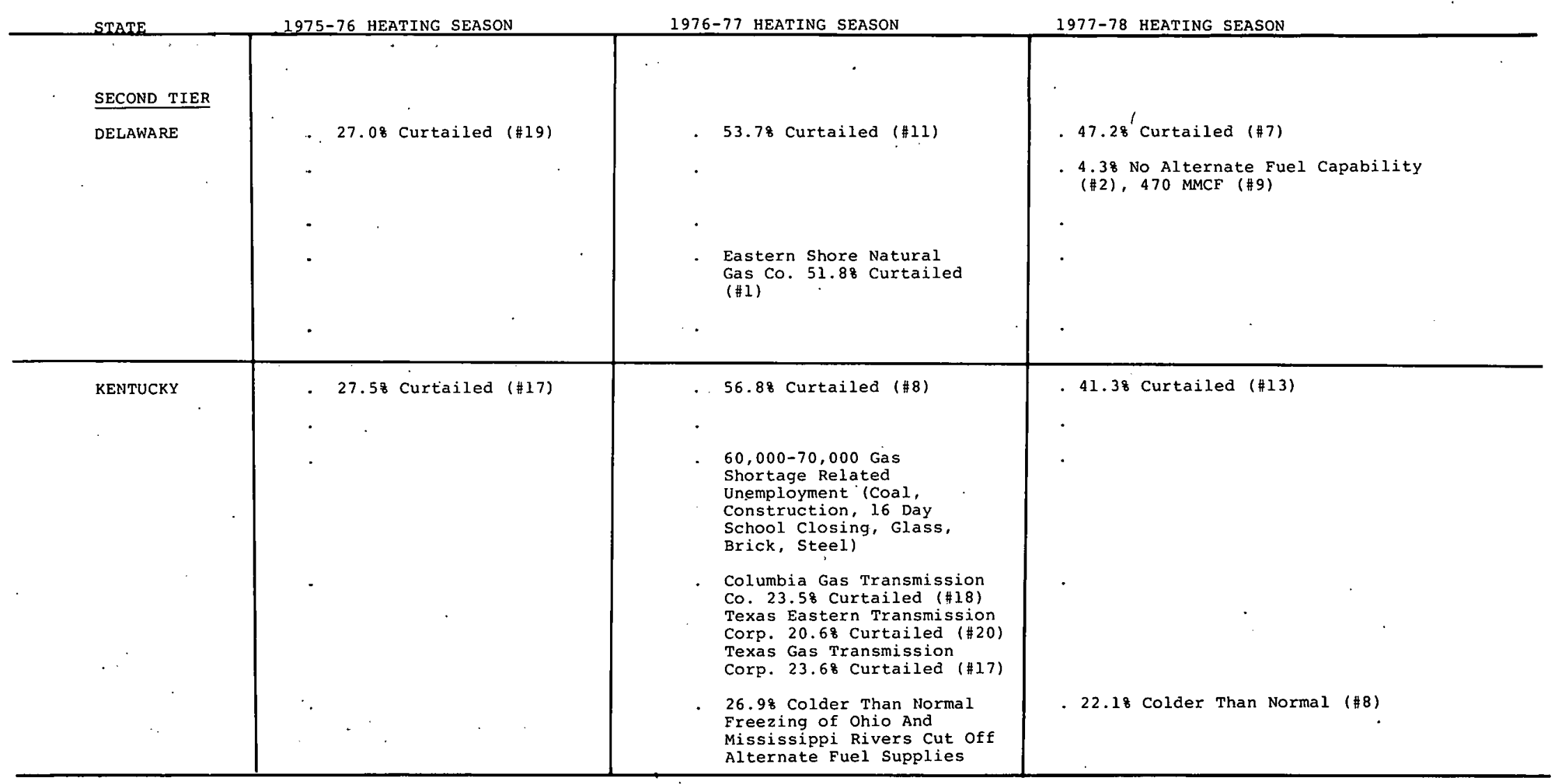




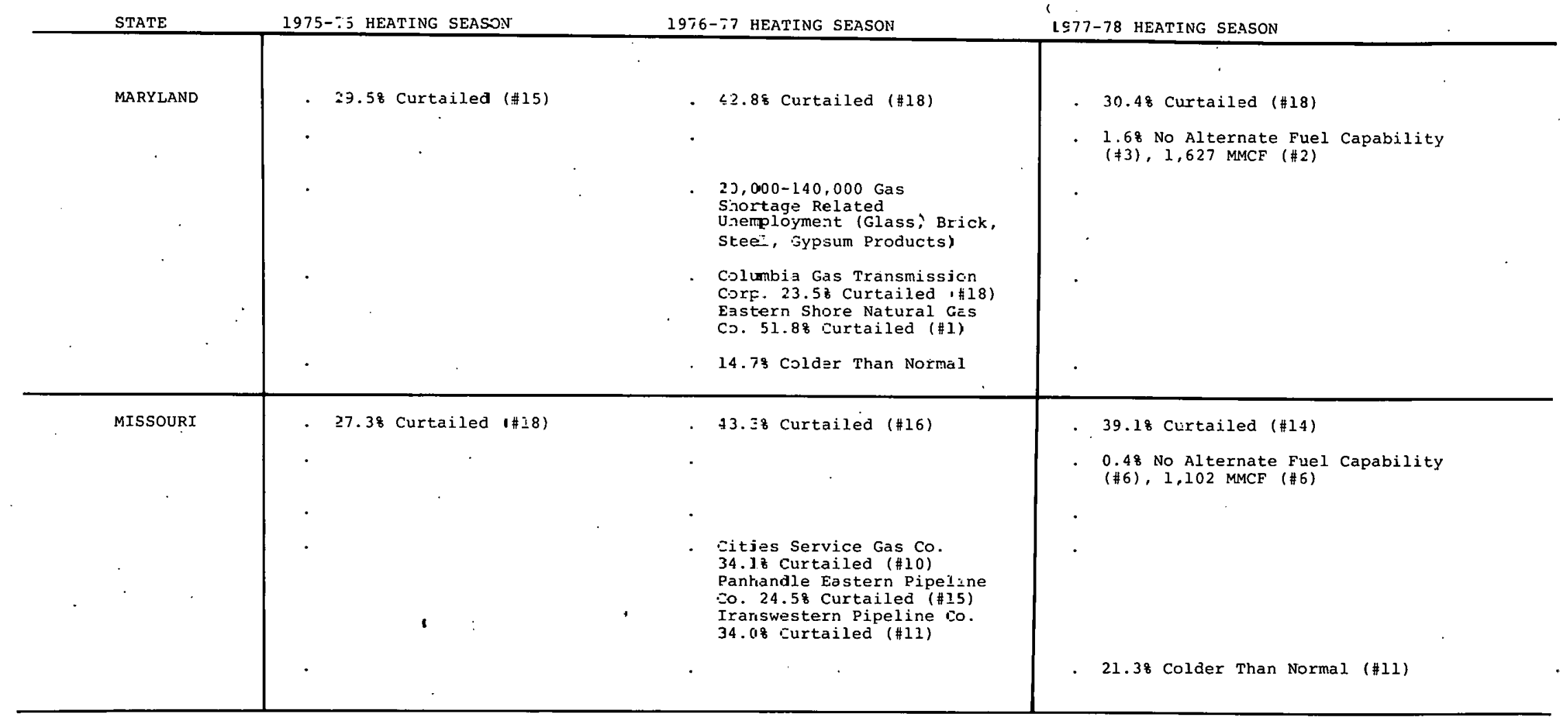


STATE

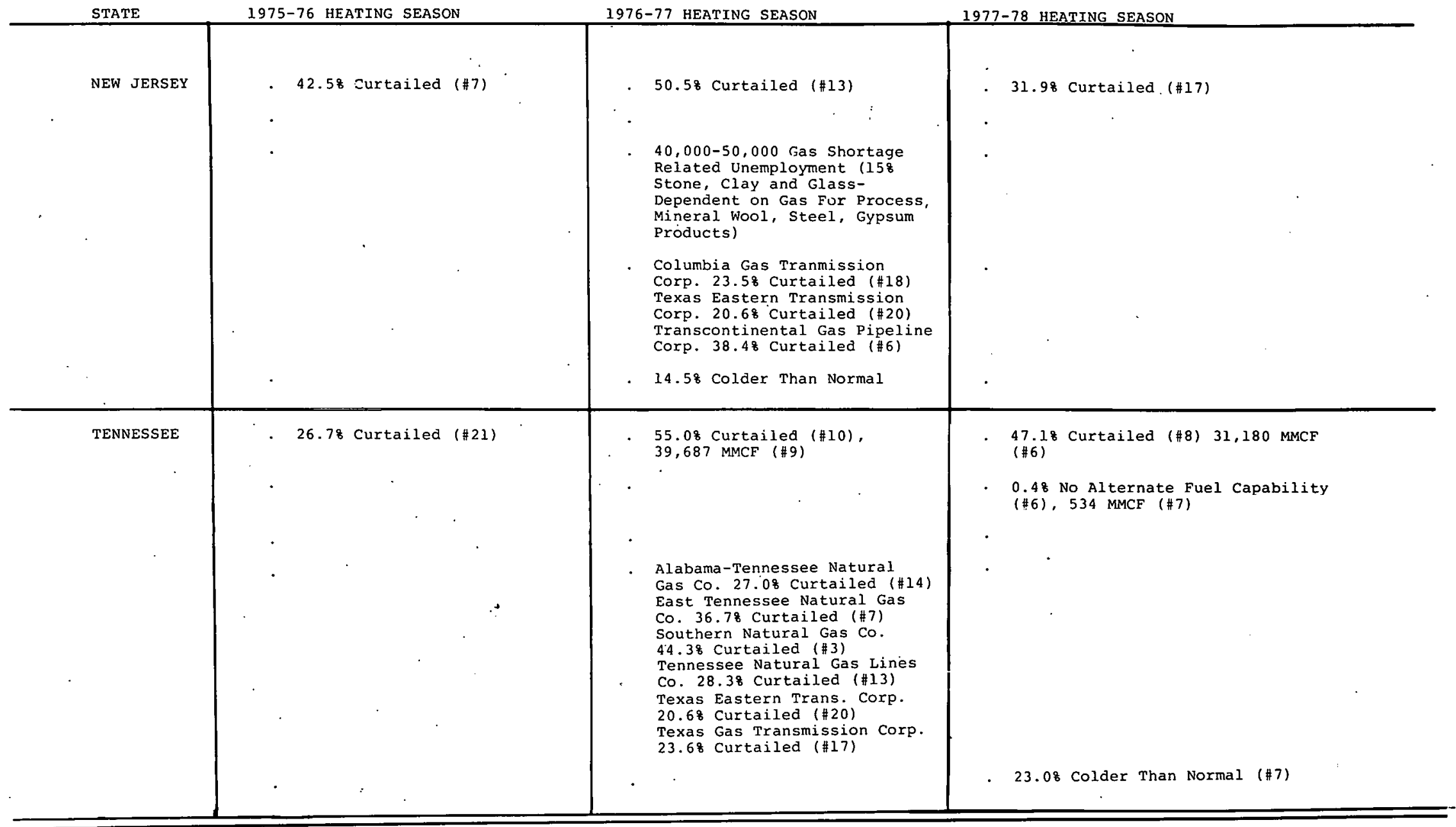




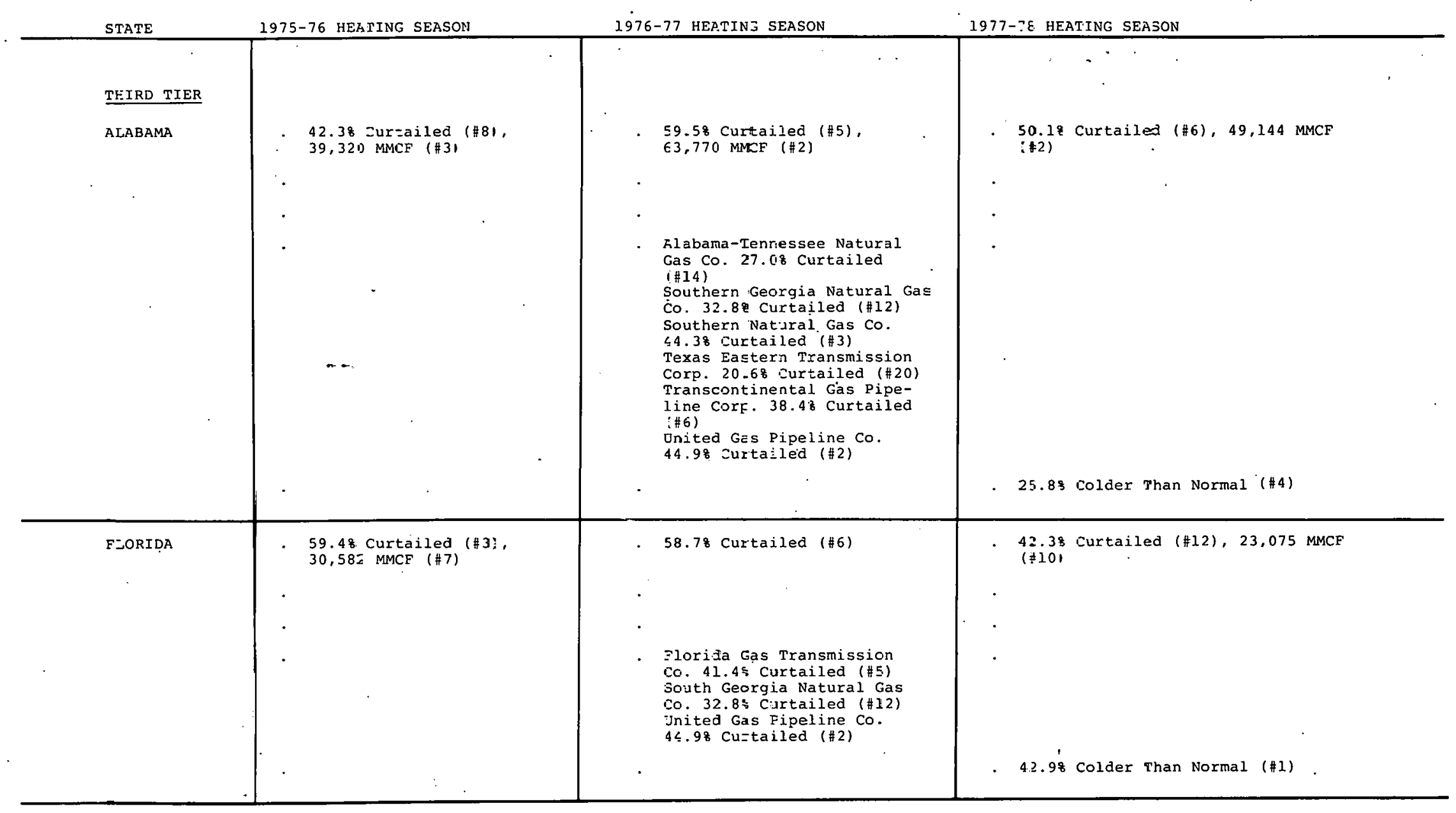




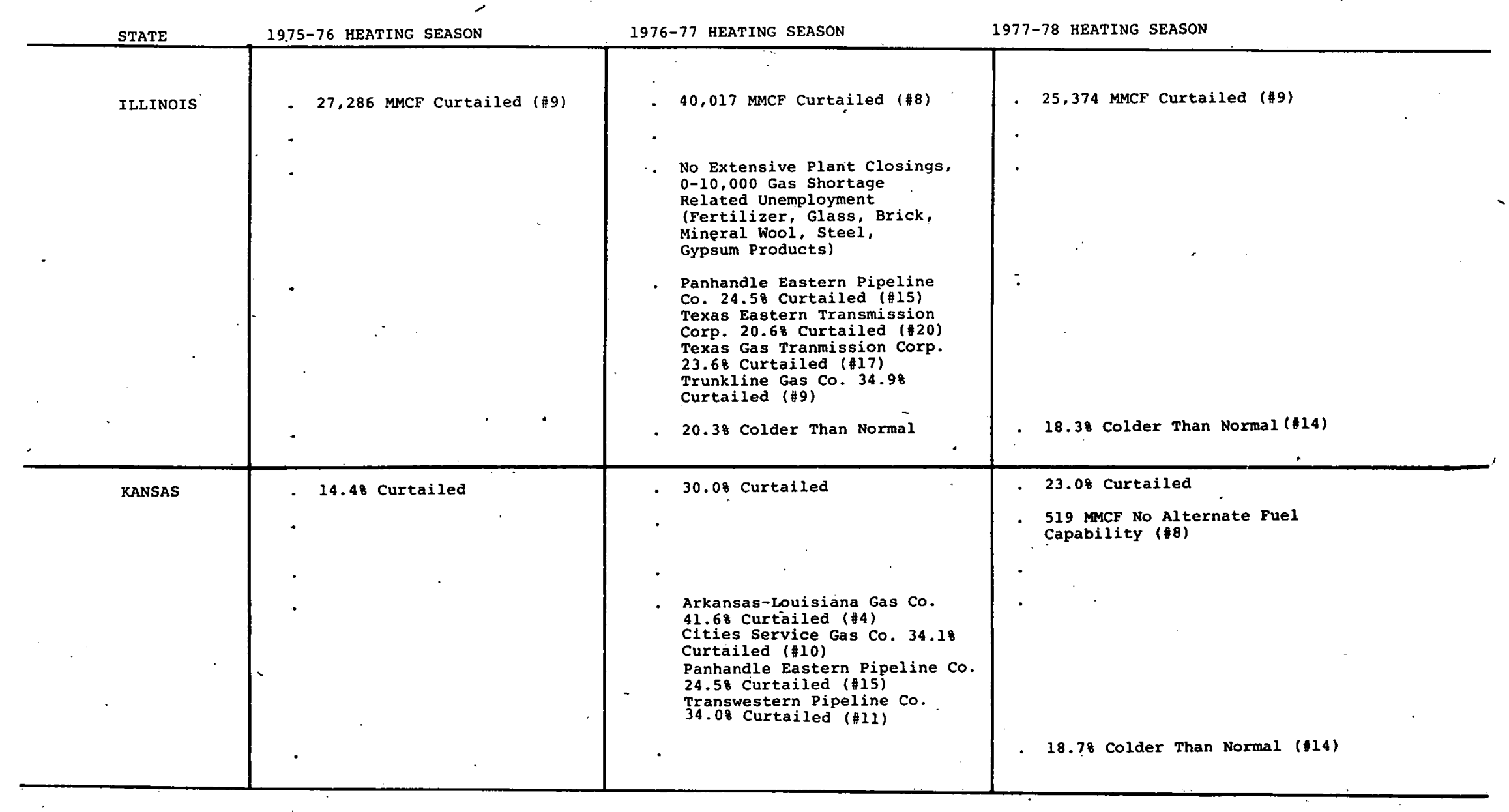




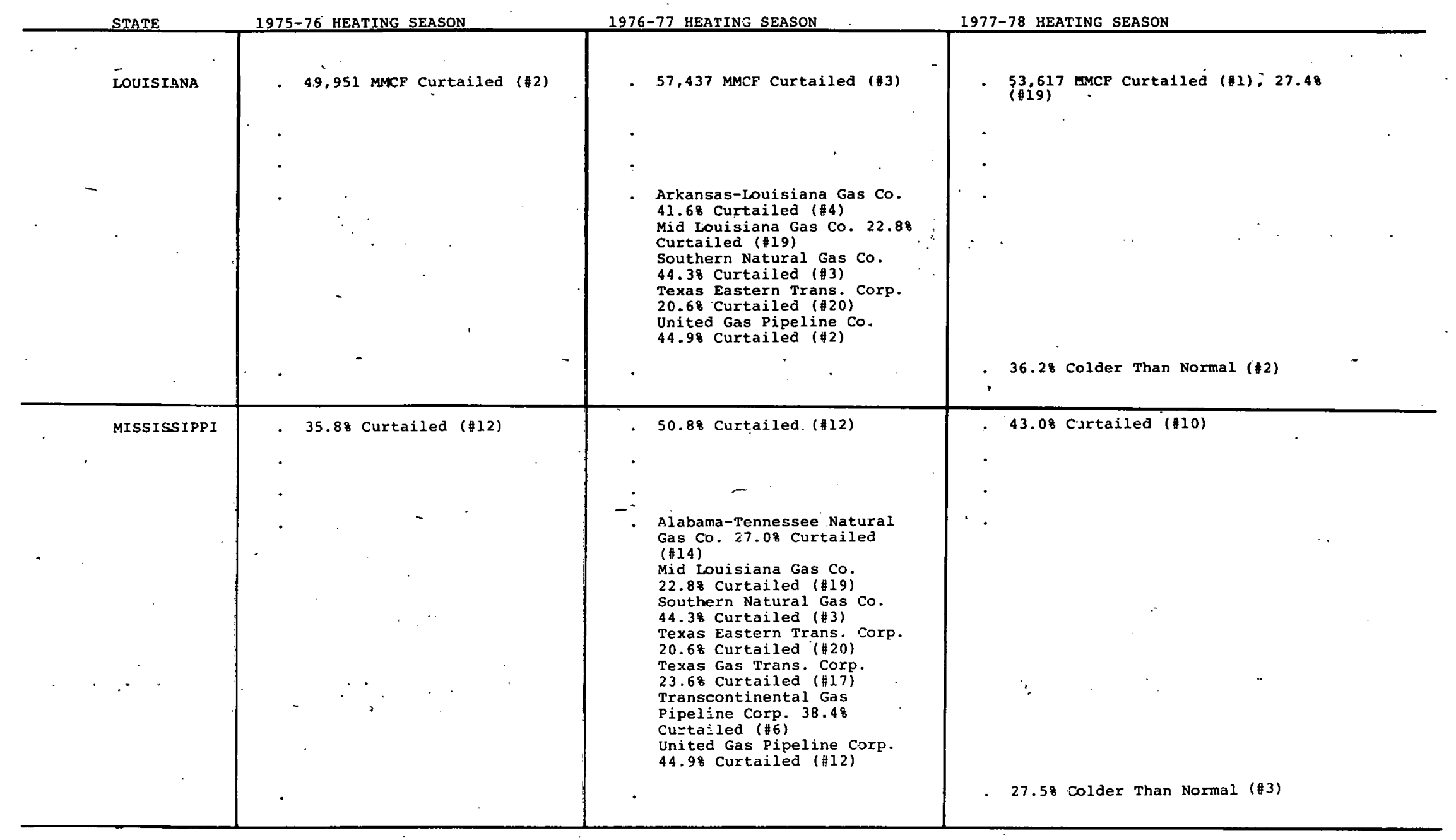




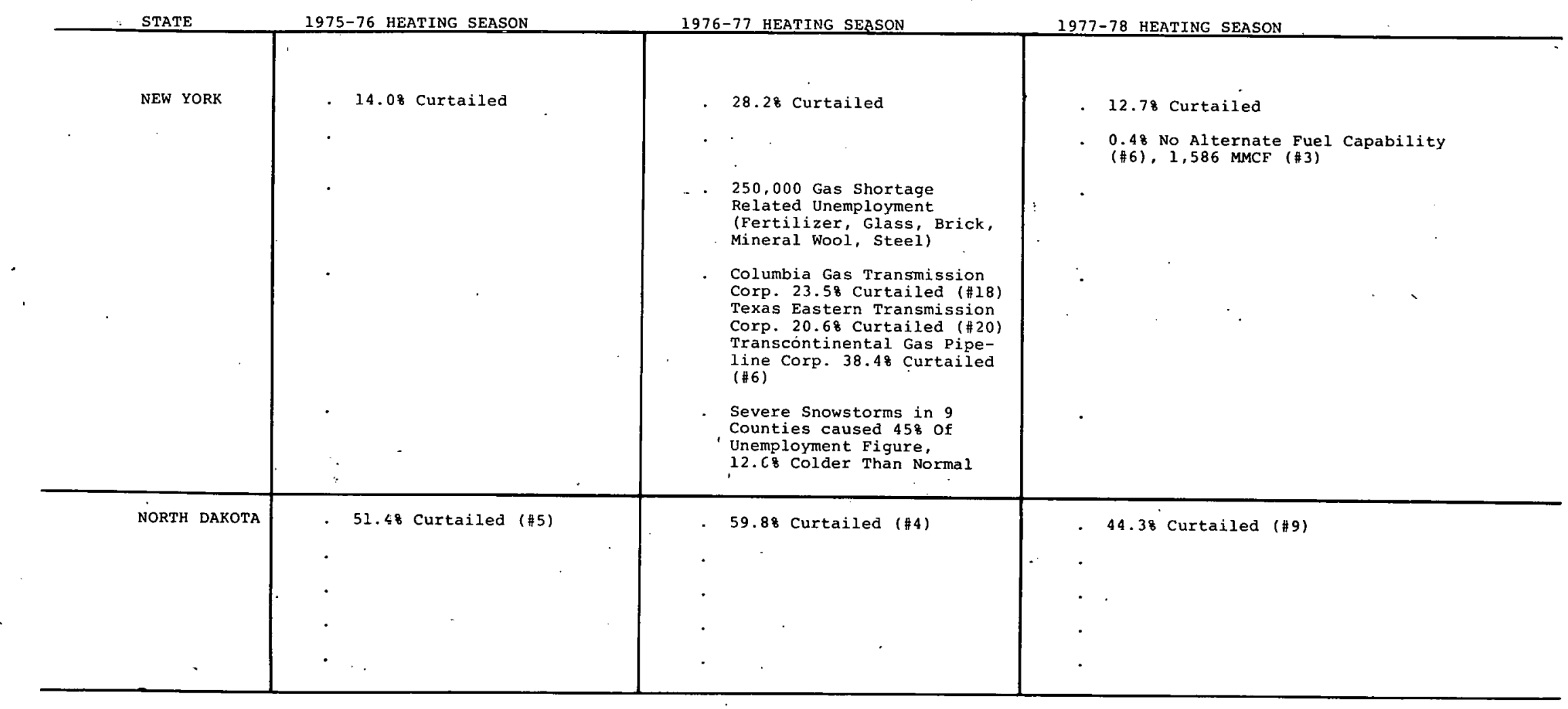




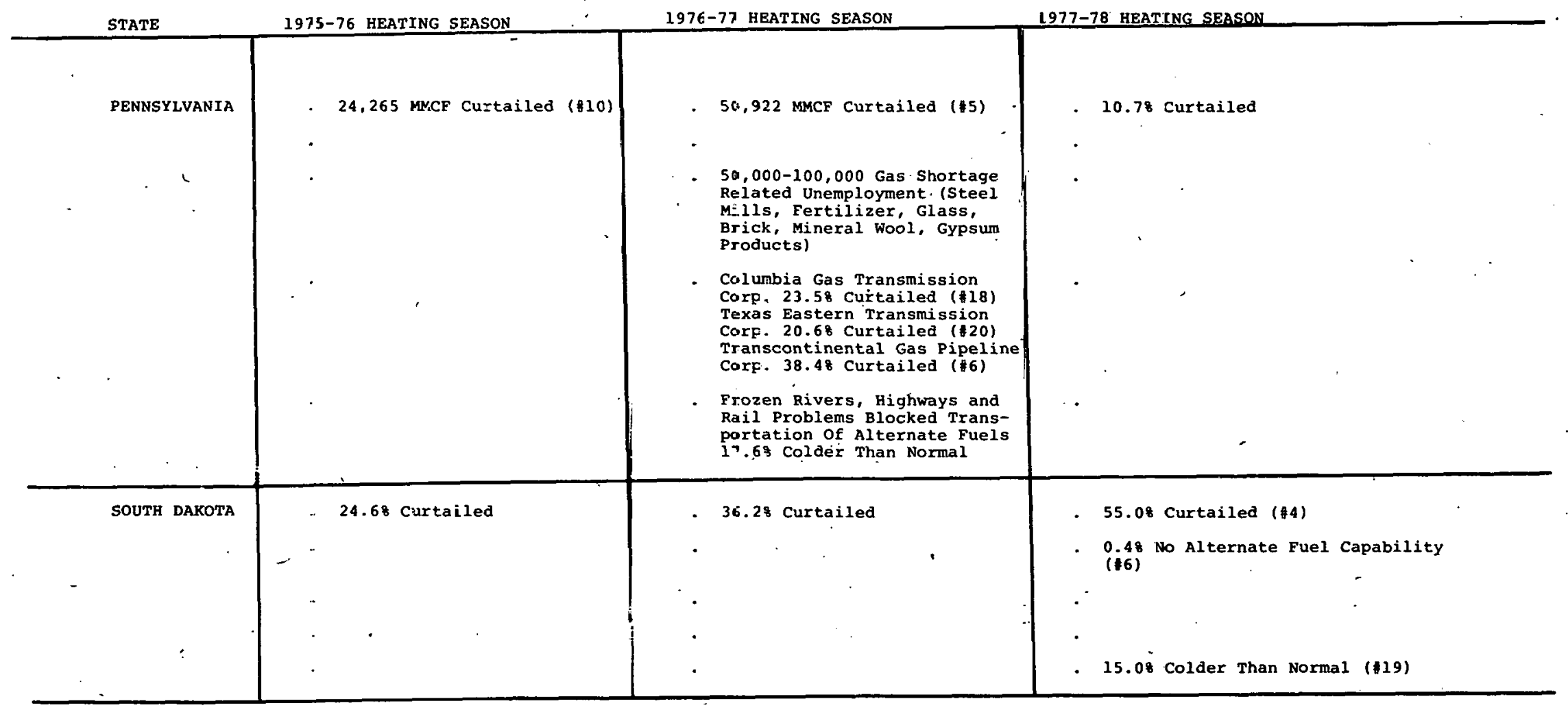




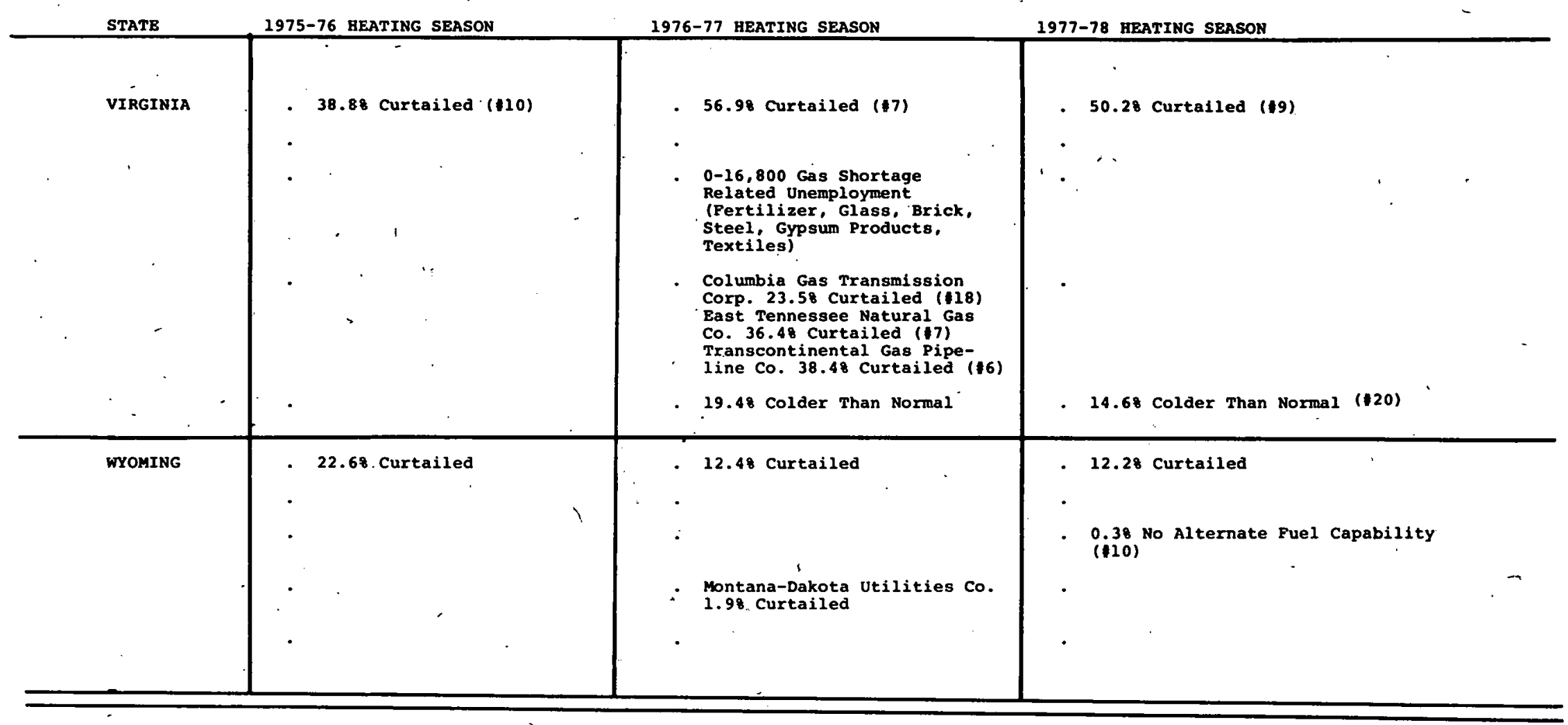




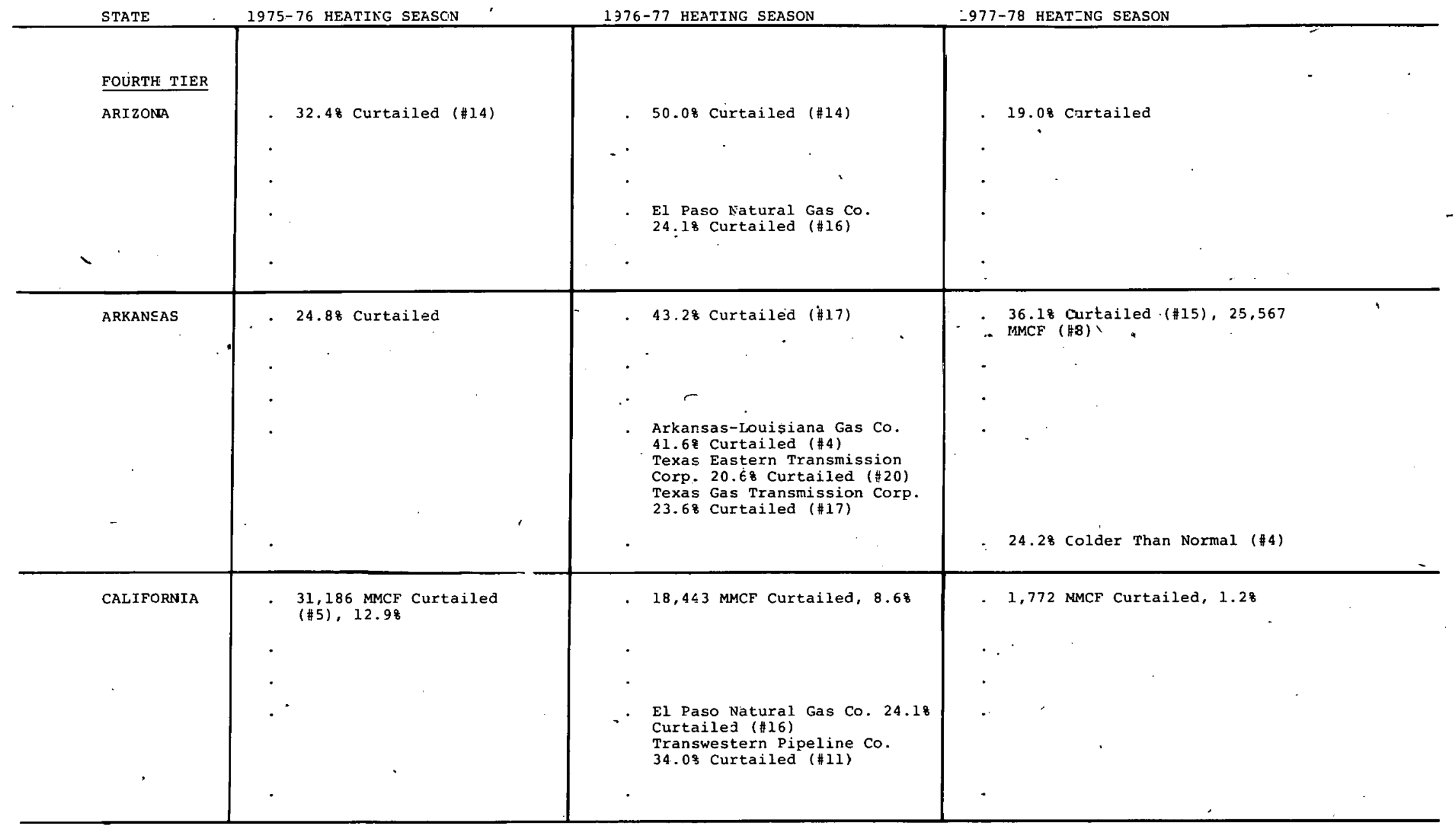




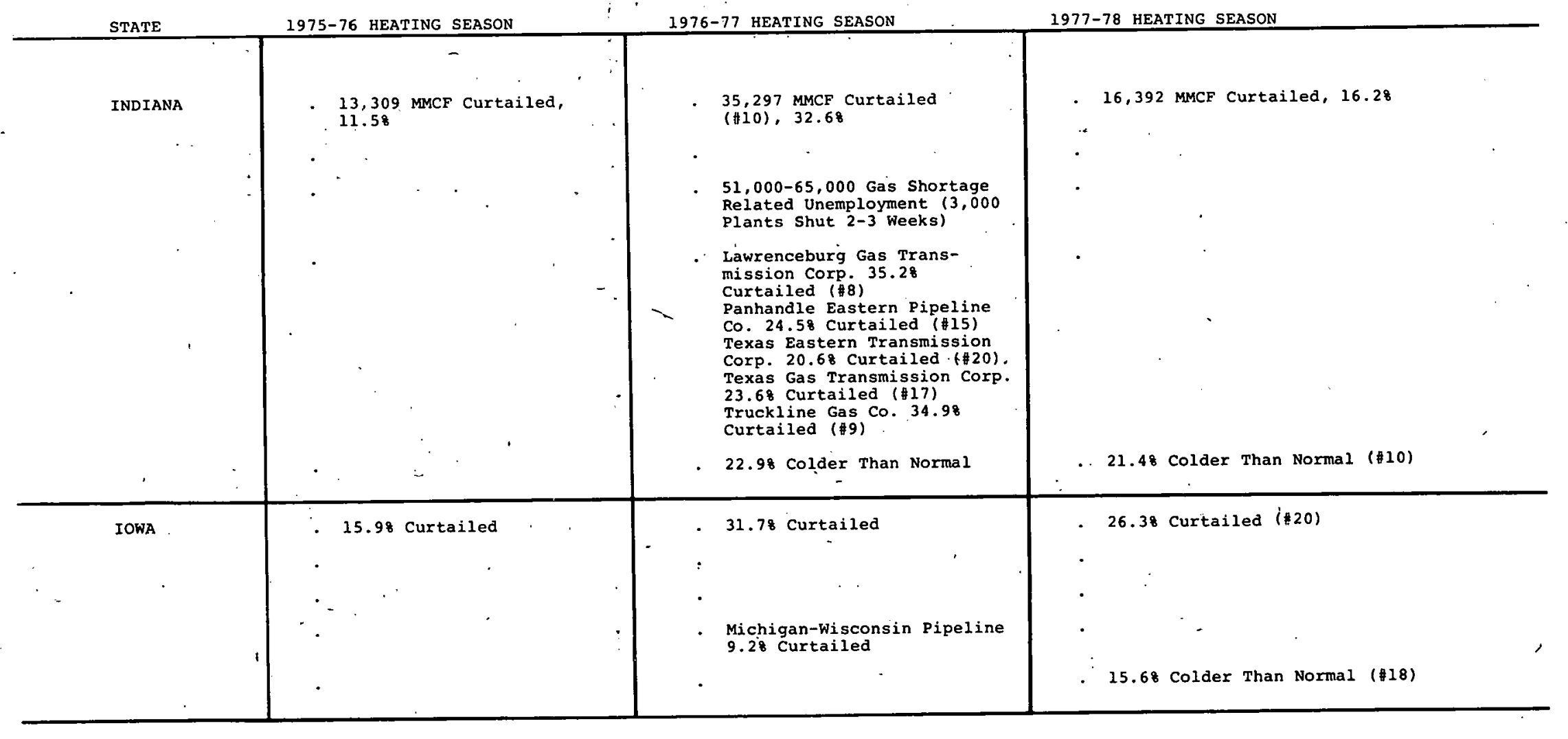




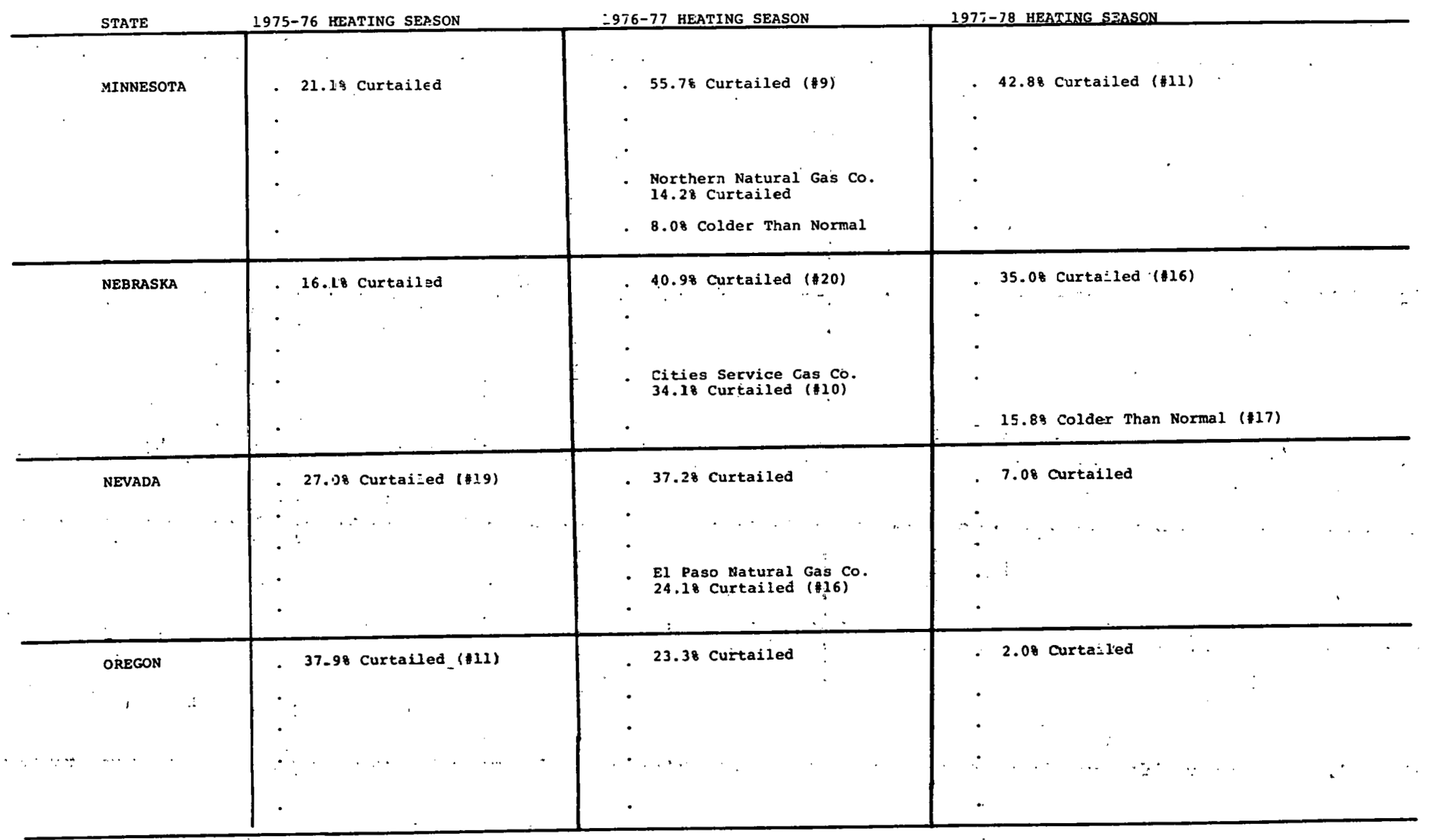




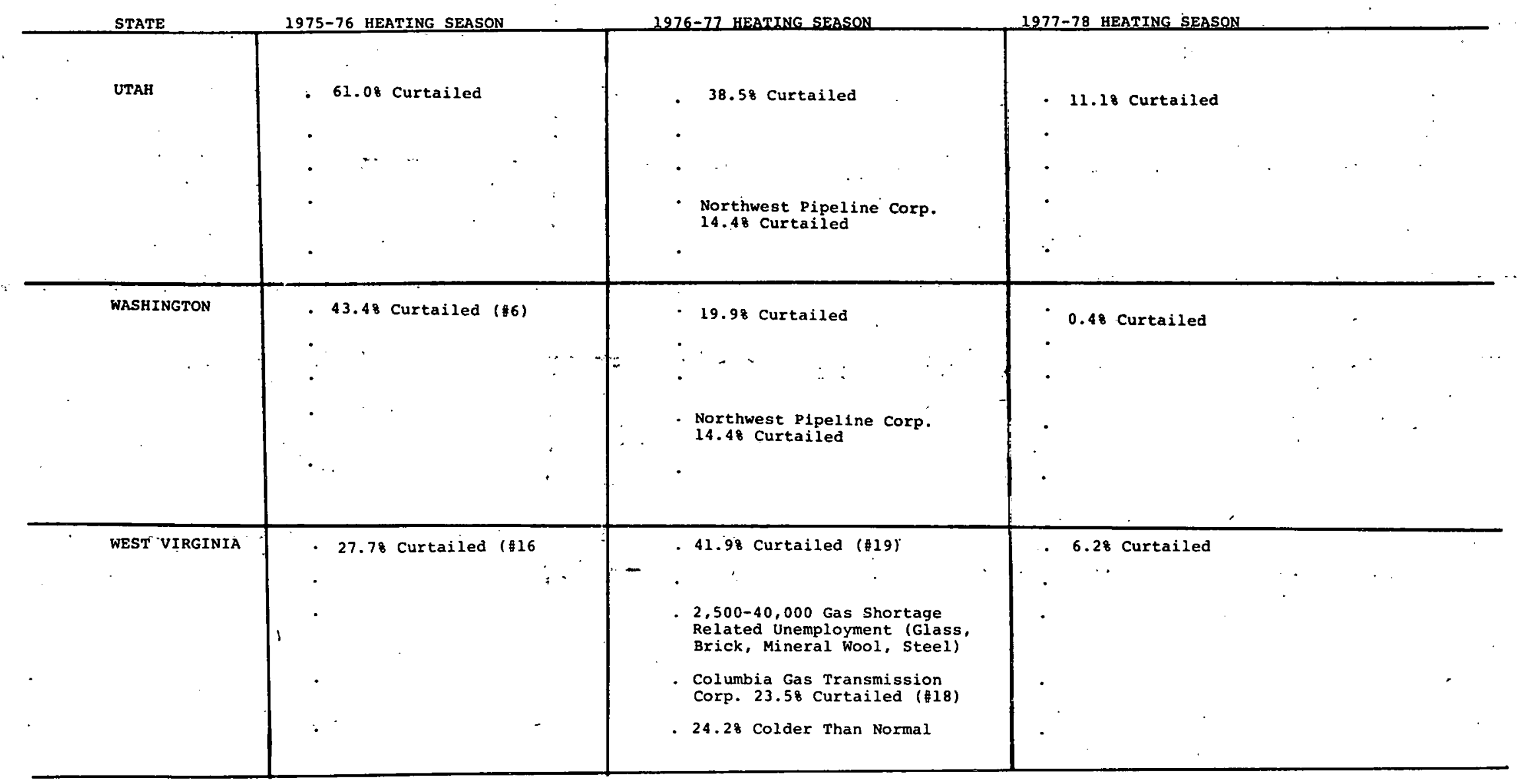


APPENDIX D

INDUSTRIAL PLANT ENERGY

CONSUMPTION DATA 
EXHIBIT D-I

Number of Industrial Plants, By State, With Fossil Fuel Consumption Above 7.4. Billion Btu/Day Selected Industries

\begin{tabular}{|c|c|c|c|c|c|c|c|c|c|}
\hline 1 & Chemicals & Basic Steel & Paper & Petroleum & Cement & $\begin{array}{l}\text { Fabricated } \\
\text { Metal }\end{array}$ & $\begin{array}{c}\text { Glass } \\
\text { Containers }\end{array}$ & $\begin{array}{l}\text { Brick, } \\
\text { clay tile }\end{array}$ & $\begin{array}{l}\text { Aluminum, } \\
\text { Other } \\
\text { Non-Ferrous }\end{array}$ \\
\hline Al abama & 5 & 2 & 8 & - & 3 & - & - & - & 1 \\
\hline Alaska & 1 & - & - & - & - & $=$ & - & - & - \\
\hline Arizona &. & 1 & - & $\cdot$ & - & - & - & - & 4 \\
\hline Arkansas & 4 & - & 2 & 1 & 1 & $-\quad-$ & $\cdots:$ & - & - \\
\hline California & 5 & 1 & 2 & 10 & 8 & - & - & - & - \\
\hline Colorado & - & 1 & - & - & - & - & - & - & - \\
\hline Connecticut & 1 & - & - & $?$ & - & - & - & - & - \\
\hline Delaware & 3 & 1. & - & 1 & - & - & - & - & - \\
\hline District of Columbia & - & - & - & - & - & - & - & - & - \\
\hline Florida & 4 & - & 8 & - & 3 & - & - & - & - \\
\hline Georg 1a & 5 & - & 10 & - & 2 & - & - & - & - \\
\hline Hawa11 & - & - & 1. & - & - & - & - & - & - \\
\hline Idaho & 2 & - & 1 & - & - & - & - & - & - \\
\hline Illinots & 6 & 8 & 1 & 7 & - & - & 2 & - & - \\
\hline Indiana & - & 6 & - & 2 & - & - & - & - & 1 \\
\hline IOWa & 4 & - & - & - & 1 & - & - & - & - \\
\hline Kanses & 2 & - & - & 5 & , & - & : & - & - \\
\hline Kentucky & 2 & 1 & 1 & 1 & - & - & - & - . . & - \\
\hline Loutsiana & 30 & - & 9 & 11 & - & - & - & - & 2 \\
\hline Maine & - & - . & 10 & - & - & - & - & - & - \\
\hline Maryland & 1 & 1 & 1 & - & - & - & - & - & - \\
\hline Massachusetts & - & - & 1. & $\because$ & - & - & - & - & - \\
\hline Michigan & - & 2 & 4 & - & 2 & - & - & - & $\because$ \\
\hline Minnesota & - & 1 & 3 & - & $=$ & - & - & - & - \\
\hline Mississippi & 2 & $\therefore=$ & 4 & 1 & - & - & - & - & - \\
\hline Missouri & $\cdot 2$ & - & $\because$ & 1 & 2 & - &,- & - & - \\
\hline Montana & - & - & - & - & - & - & - & - & 1 \\
\hline Nebraska & 3 & - & - & - & - & - & - & - & - \\
\hline Nevada & $i$ & - & - & - & - & - & - & - & 1 \\
\hline New Hampshire & - & - & 1. & - & $\therefore$ & - & - & - & - \\
\hline New Jersey & 7 & - & 4 & 6 & - & - & - & - & - \\
\hline New Mexico & - & - & - & - & 1 & - & - & - & - \\
\hline New York & 4 & 1 & 3 & 1 & 1 & - & - & - & - \\
\hline North Carol ina & 5 & - & 5 & - & - & - & -1 & - & $\cdot$ \\
\hline North Dakota & - & - & - & 1 & - & - & -1 & - & - \\
\hline Ohio & 6 & 11 & 4 & 3 & 2 & - & - & - & - \\
\hline Oklahoma & - & - & - & 3 & 1 & - & - & - & - \\
\hline Oregon & - & - & 2 & - & - & - & - & - & - \\
\hline Pennsylvania & 3 & 17 & 3 & $\dot{3}$ & 2 & 1 & - & - & - \\
\hline Rhode Island & $\cdot \quad-$ & - & - & $=$ & - & - & - & - & . - \\
\hline South Carol ina & 2 & 2 & -3 & - & 2 & - & - & - & $\sim$ \\
\hline South Dakota & - & $=$ & - & - & 1 & - & - & - & $\cdot$ \\
\hline Tennessee & 9 & - & 2 & - & 2 & - & - & - & 1 \\
\hline Texas & 35 & 2 & 4 & 19 & 8 & - & - & - & 2 \\
\hline Utah & 1 & 1 & - & - & - & - & - & - & 1 \\
\hline Vermiont & - & - & - & - & - & - & - & - & - \\
\hline Virginta & 8 & - & 5 & 1 & 1 & - & . - & - & - \\
\hline Washington. & - & 1 & 7 & 1 & 1 & - & - & - & 1 \\
\hline West Virginia & 10 & 1 & - & 1 & - & - & - & - & - \\
\hline Wisconsin & - & - & 7 & - & - & - & - & - & - \\
\hline Wyoming & 3 & - & - & 4 & $\cdot$ & - & - & - & $\because$ \\
\hline U.S. Total & 176 & 61 & 115 & 83 & 44 & 1. & 2 & 0 & 17 \\
\hline
\end{tabular}

Source: Low-Btu Gas Induatilal Applications AnalyBis, Work Papars, Systems Consultants, Inc., November 1978. 
APPENDIX E

SUMMARY COMMENTS FROM TNDUSTRY INTERVIEWS

ON ANTICIPATED GASTFTFR INVESTMENTS

$i^{\prime}$ 
Gasifier Investment Plans Large Potential Users

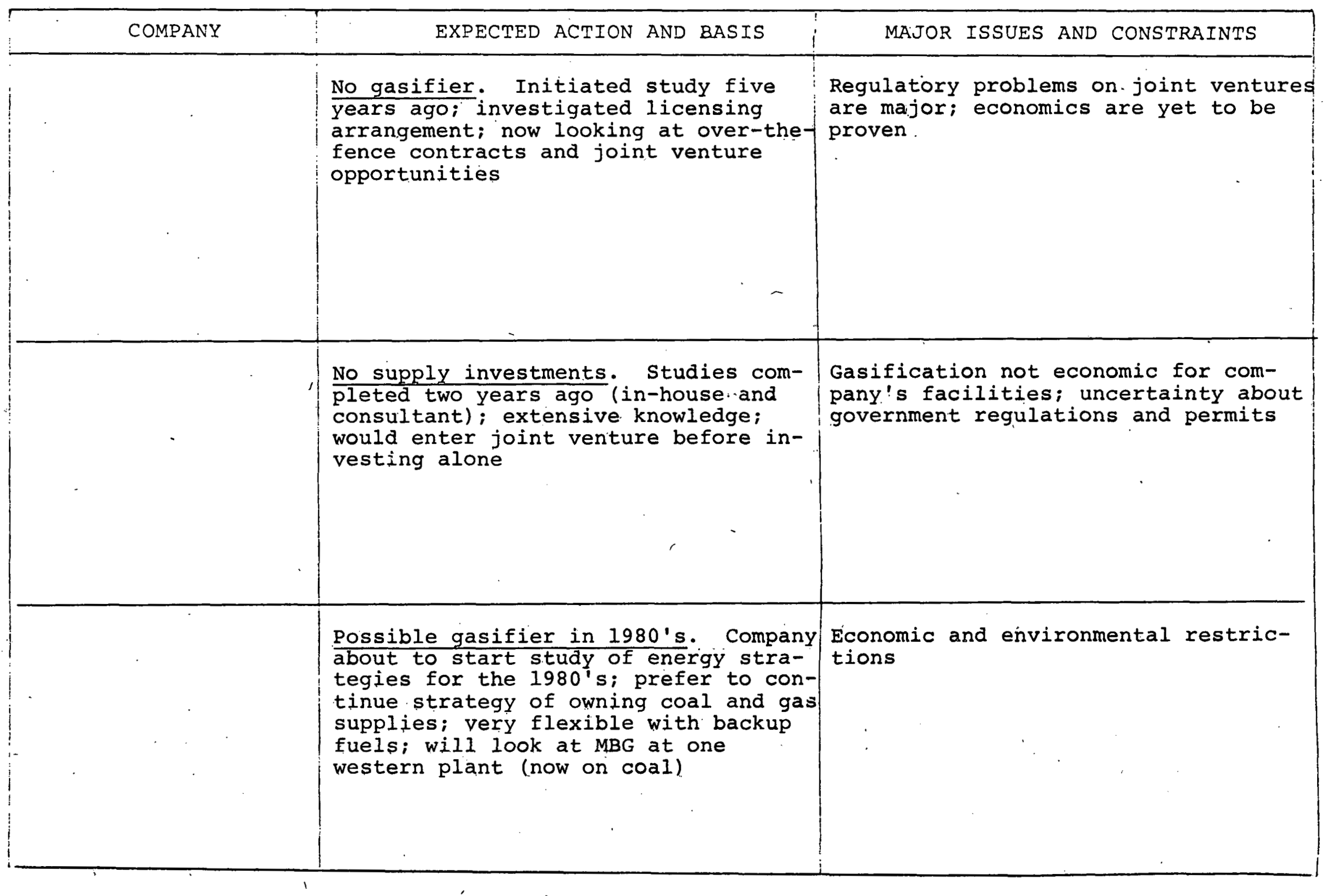




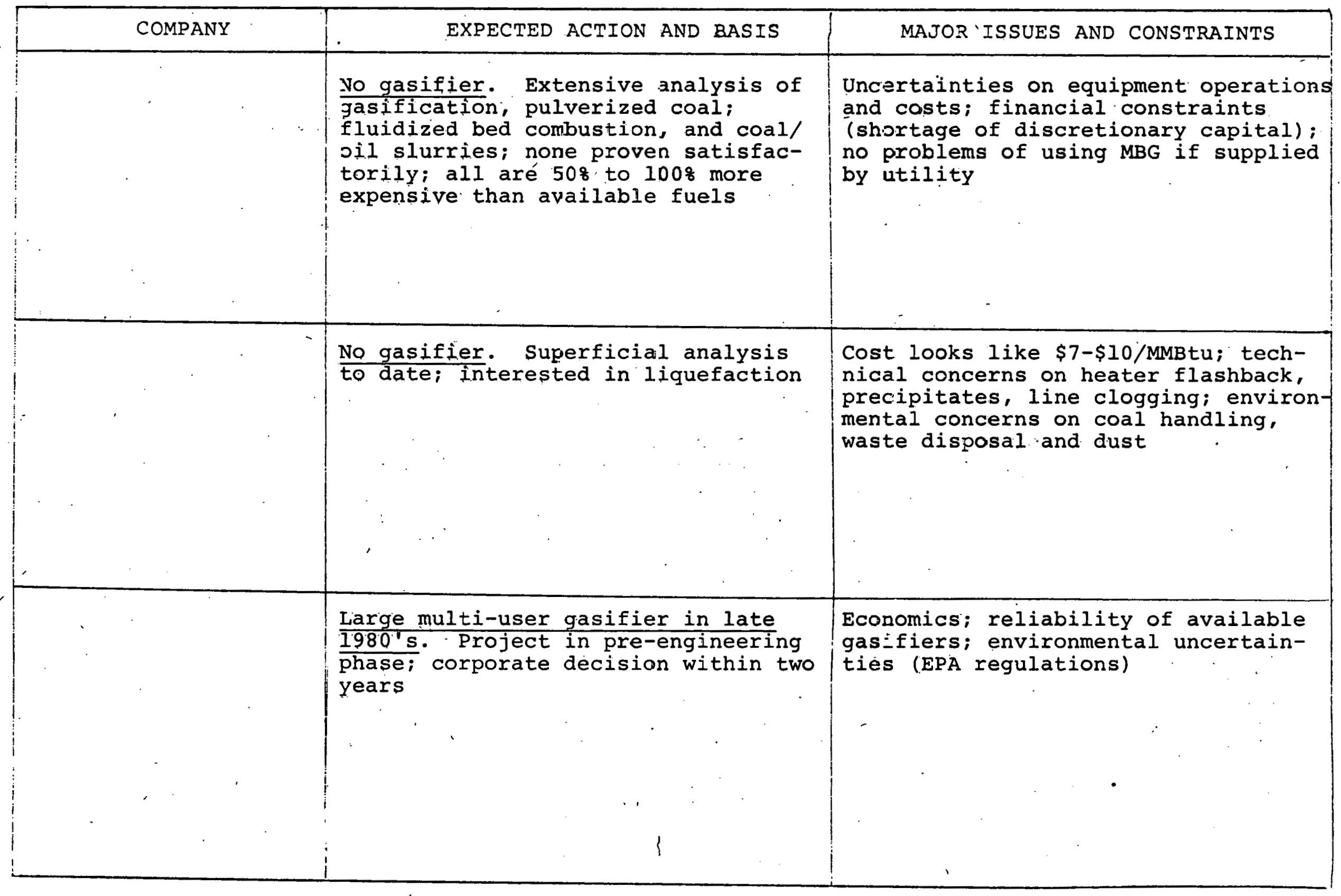




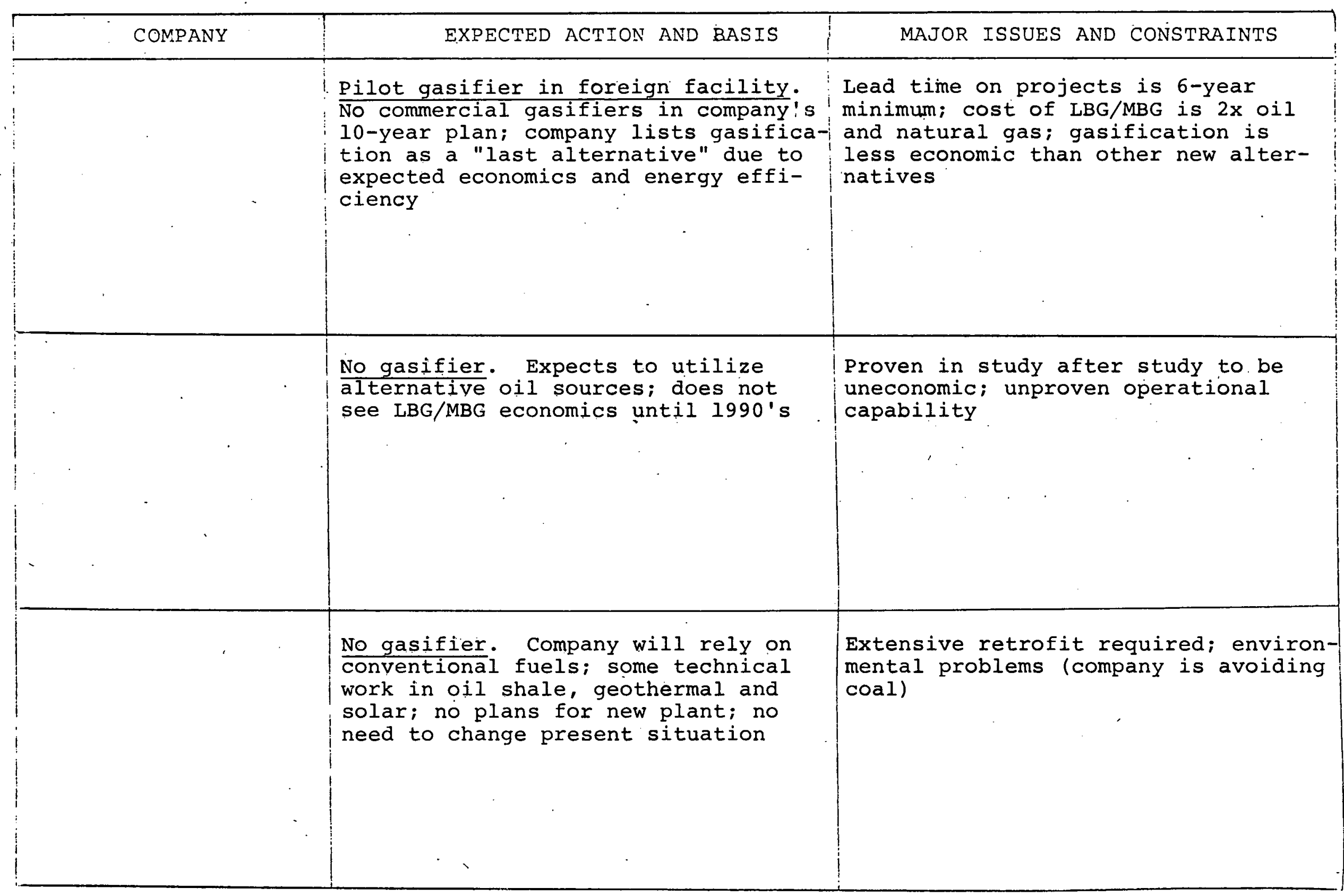




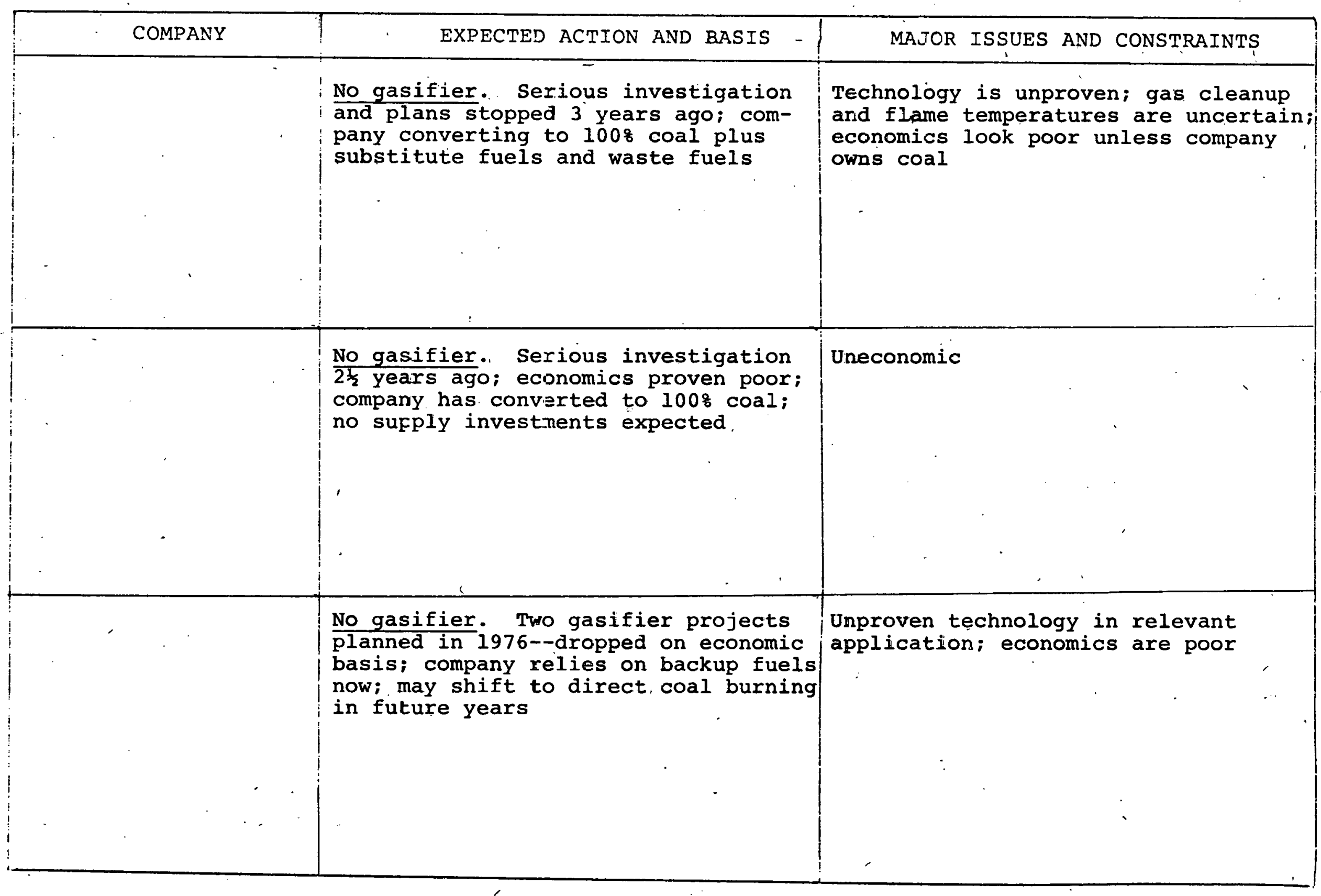




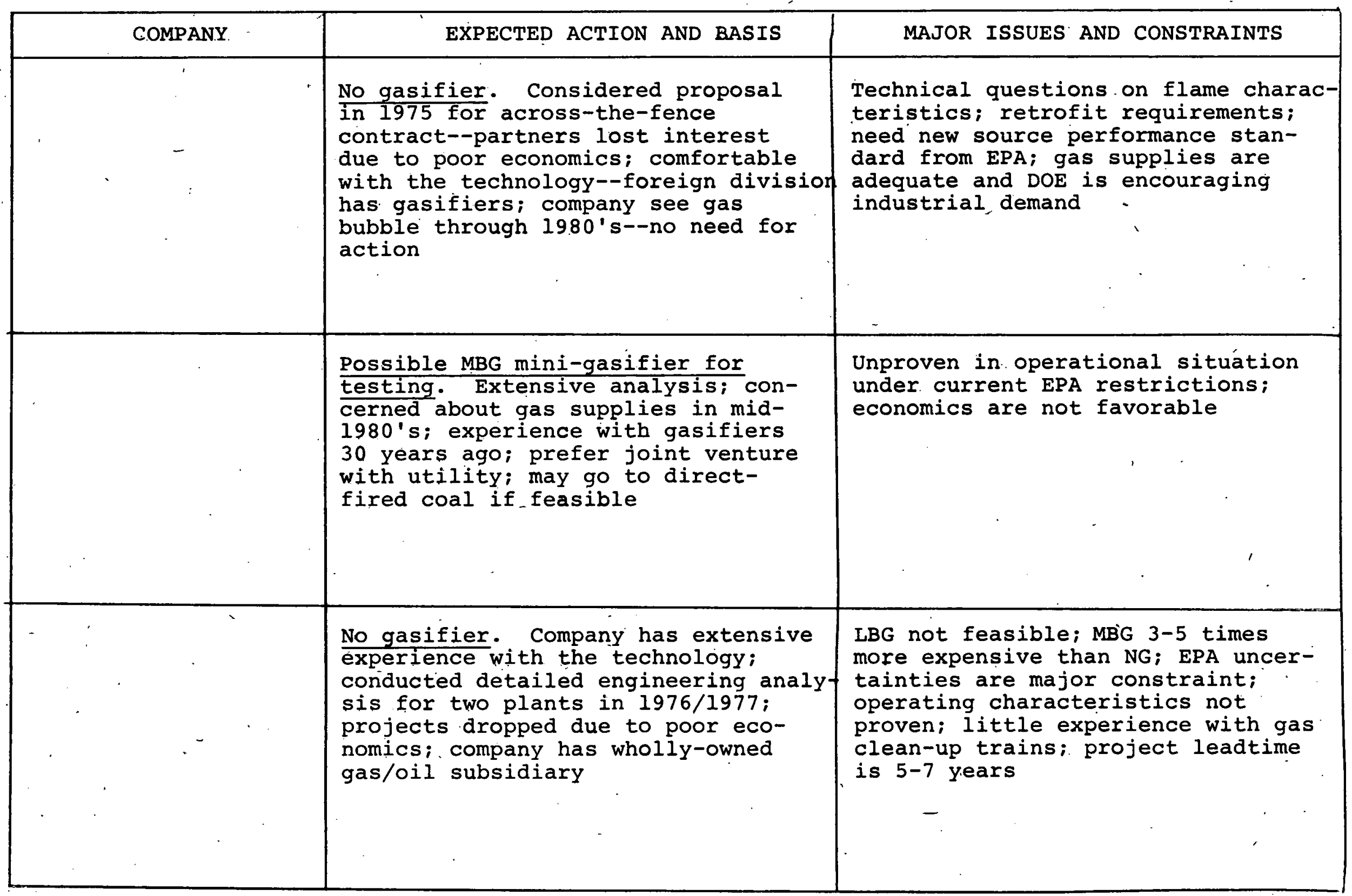




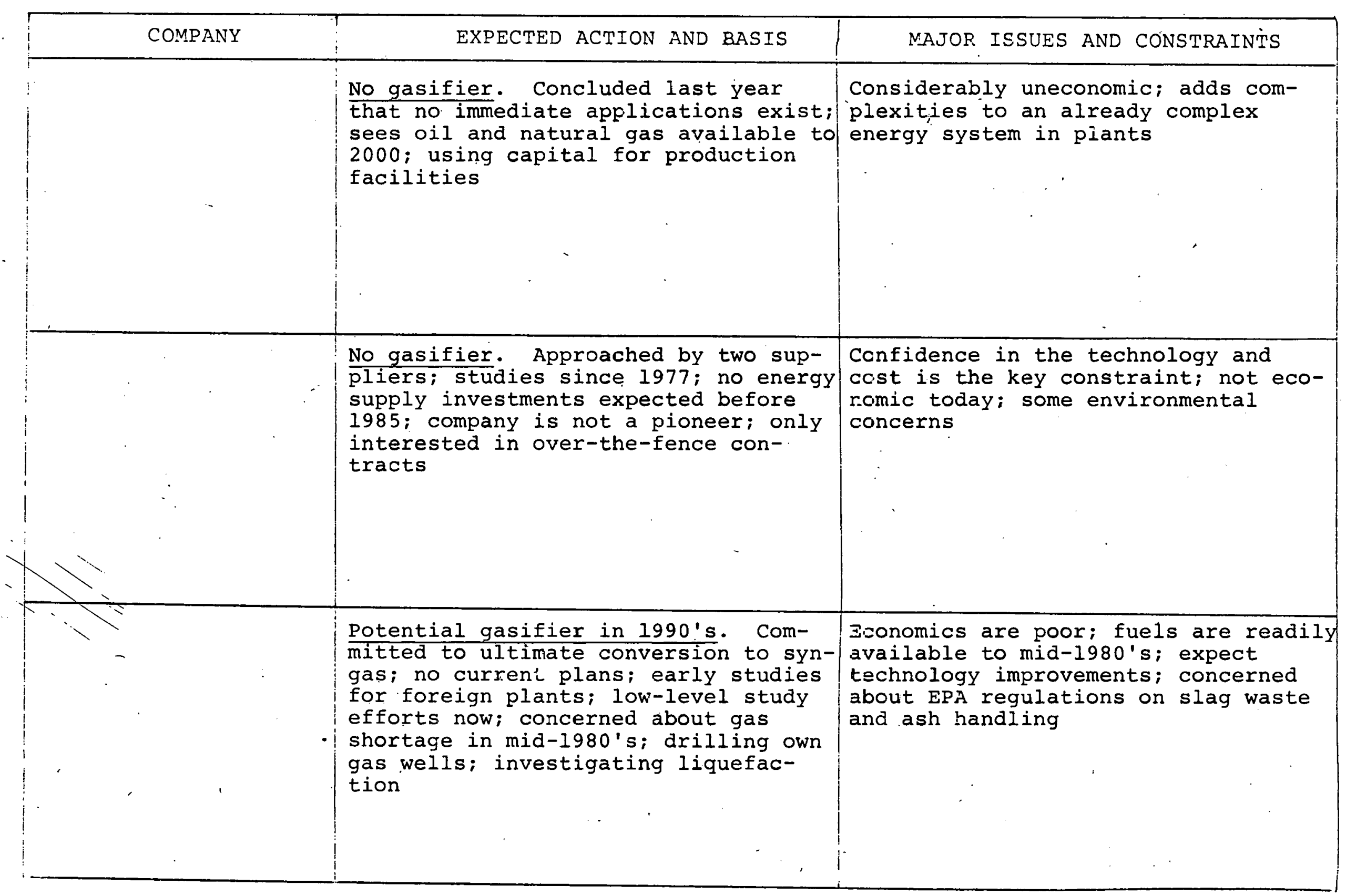


Page 7 of 8

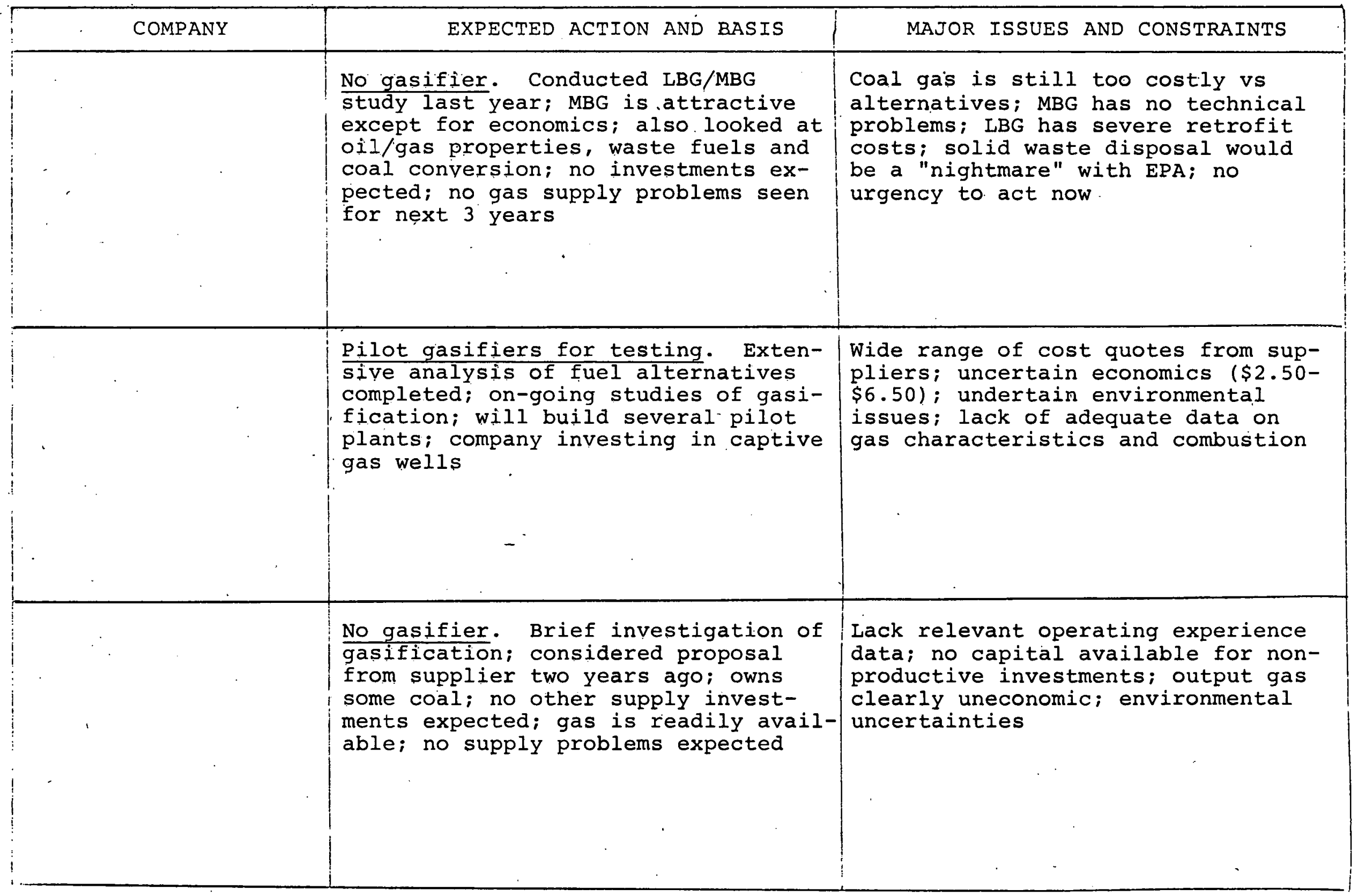




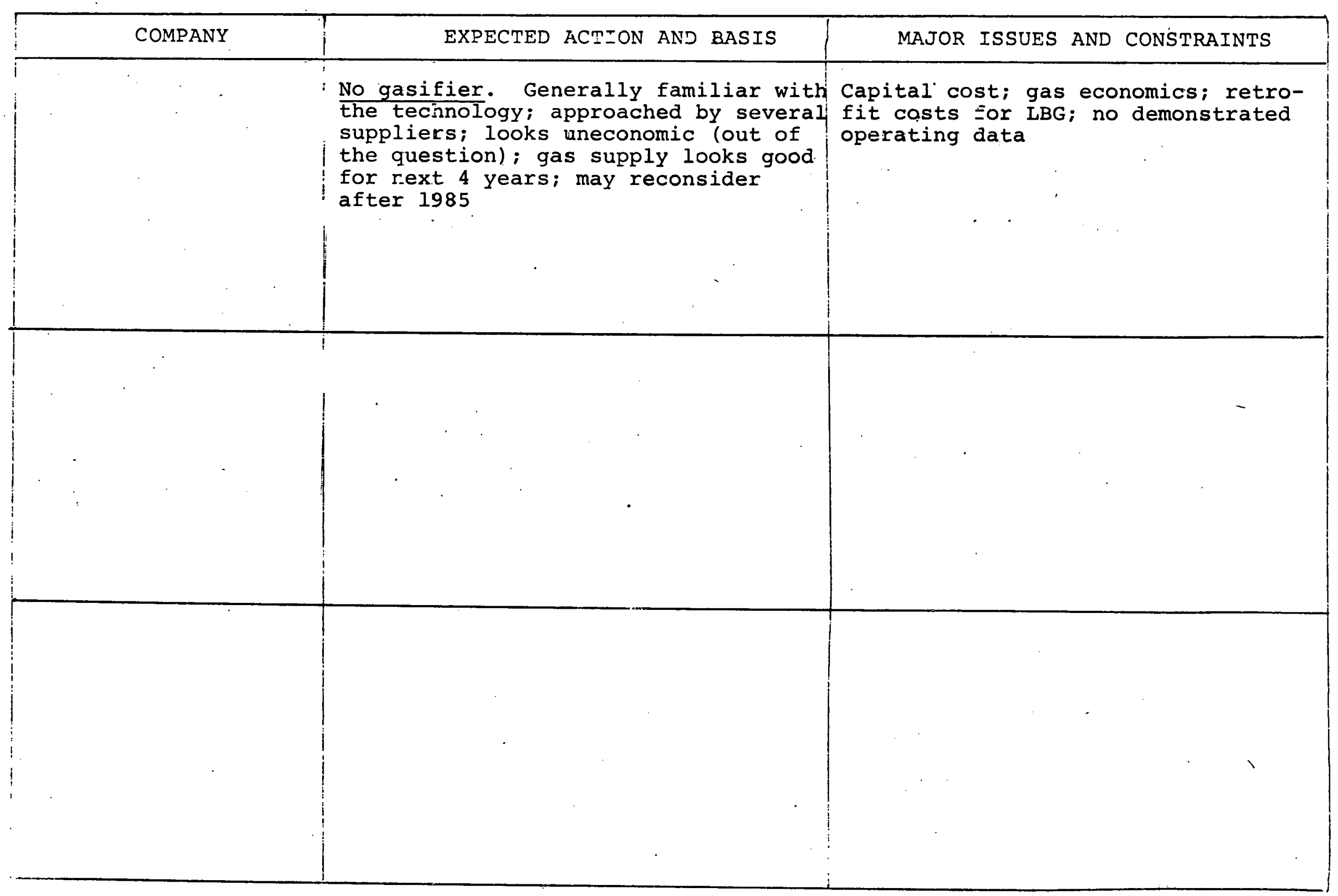


Gasifier Investment Plans Medium and Small Potential Users

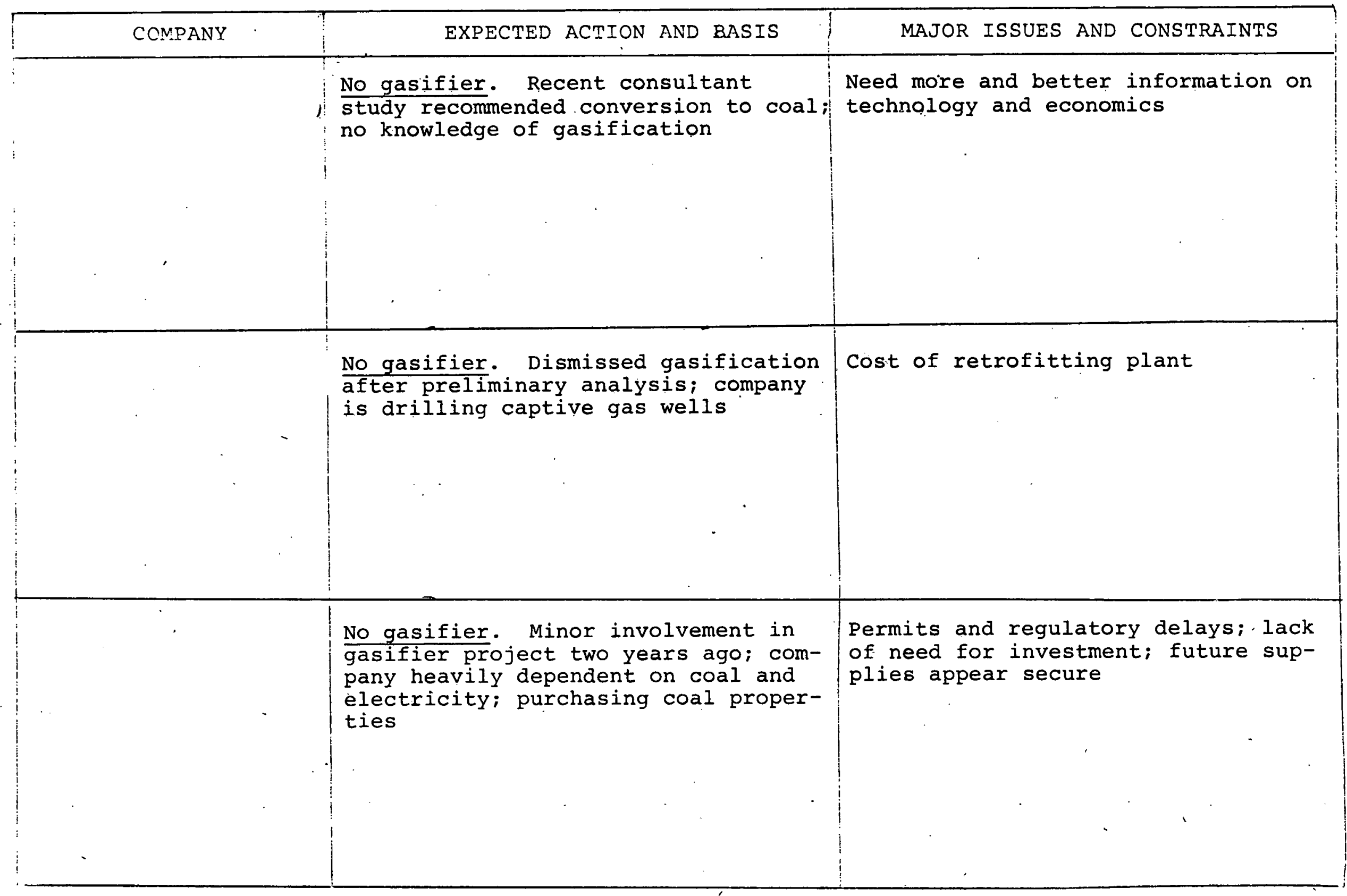




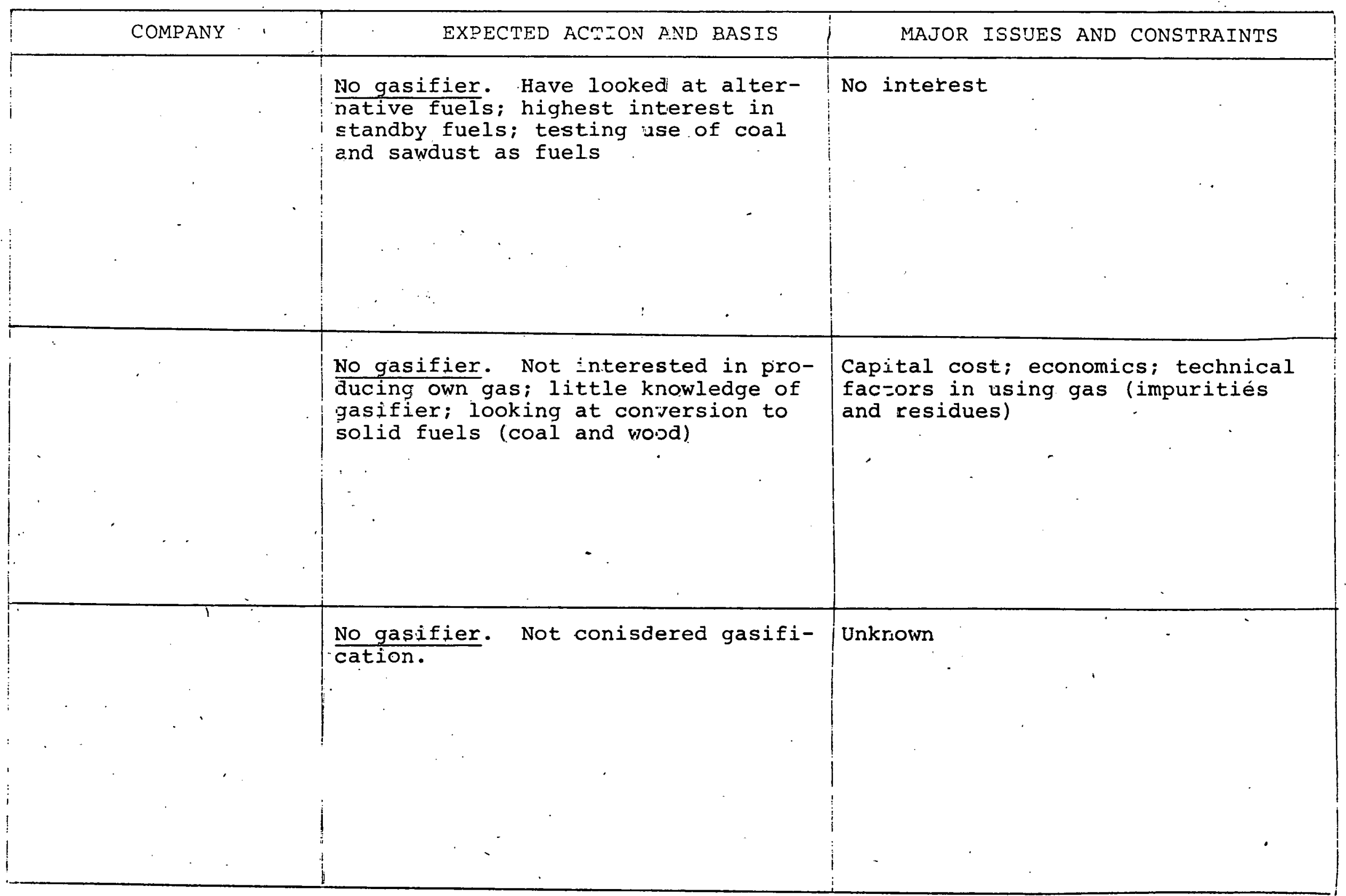


Page $\underline{3}$ of $\underline{7}$

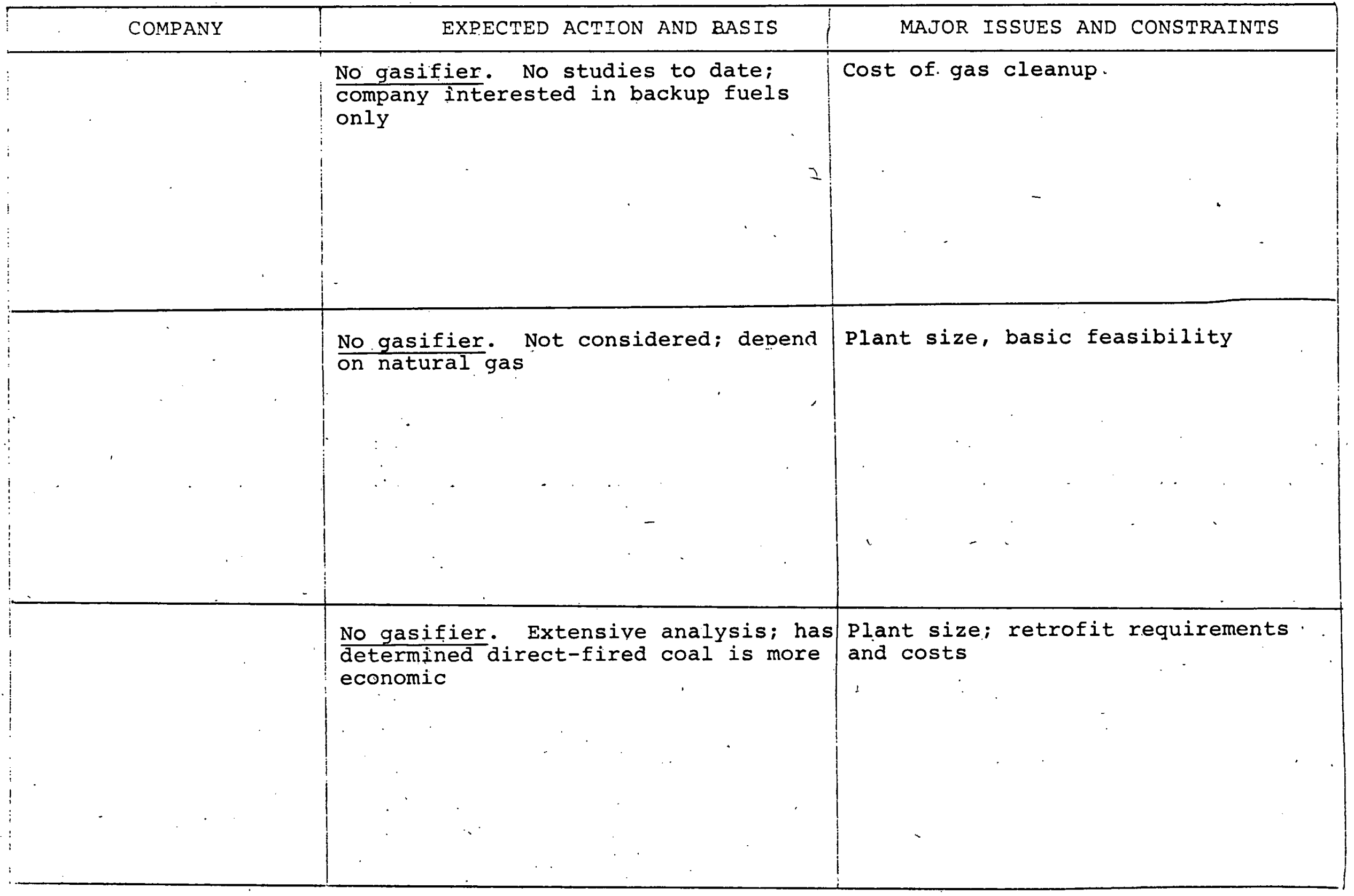


Page $\underline{4}$ of $\underline{7}$

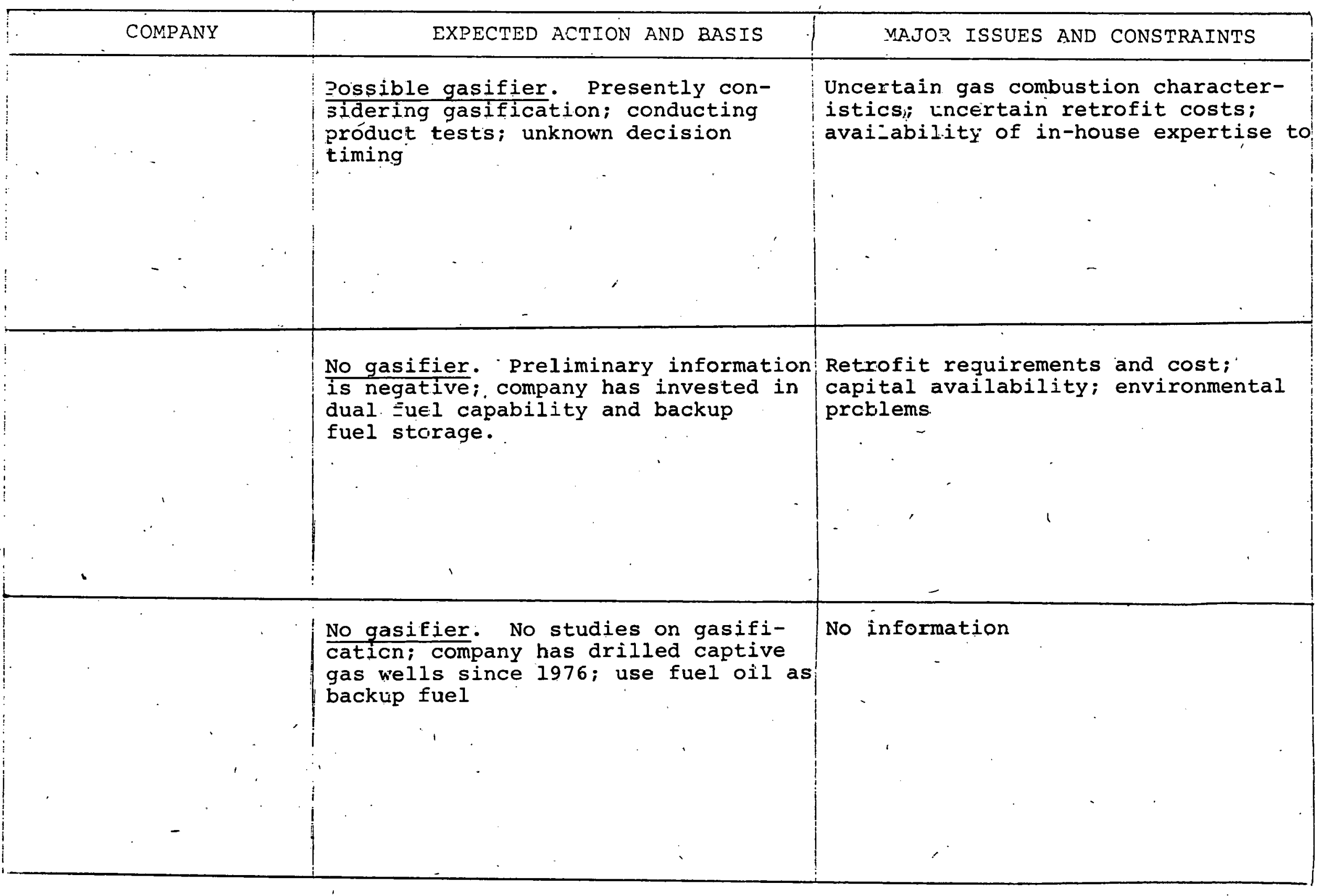




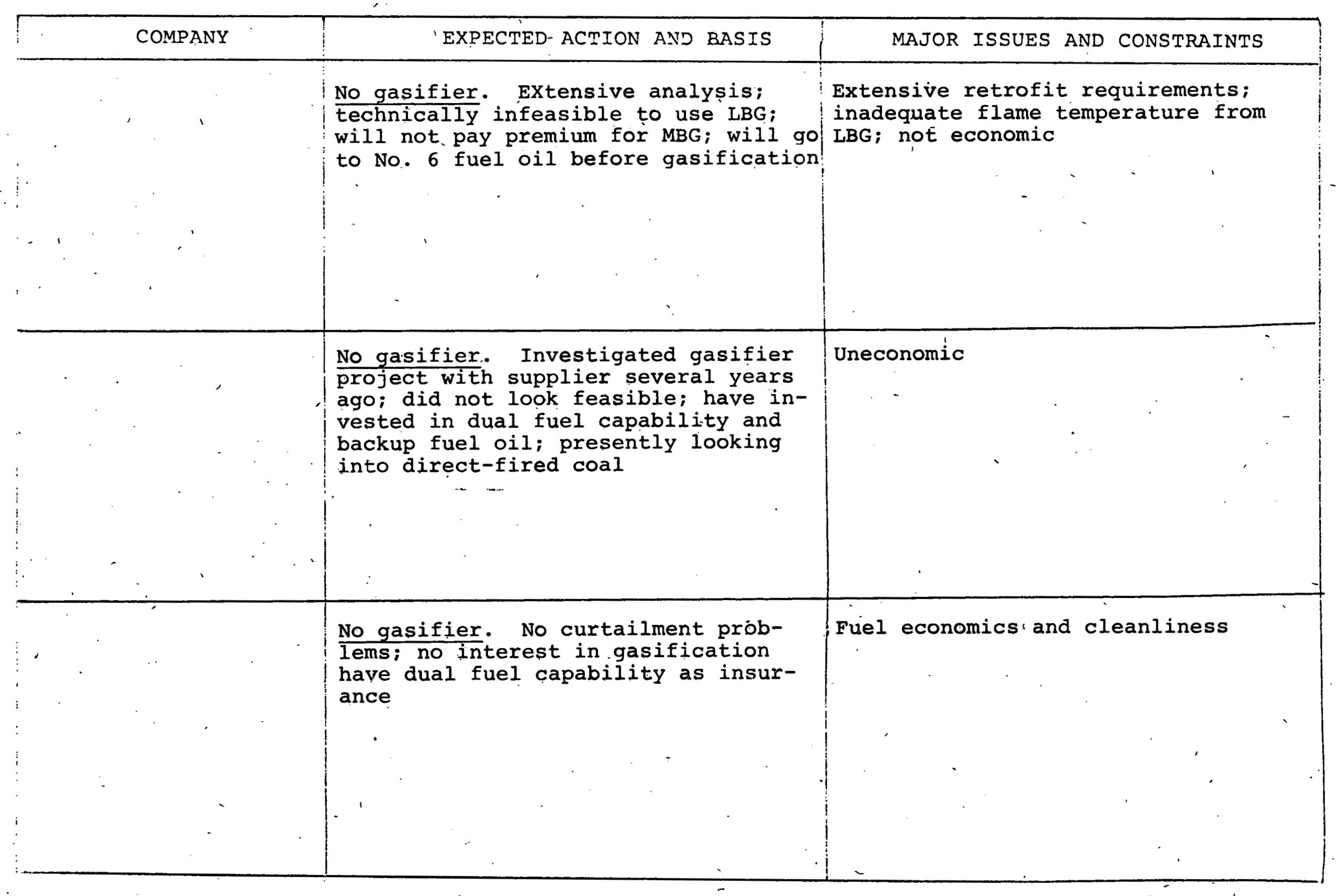




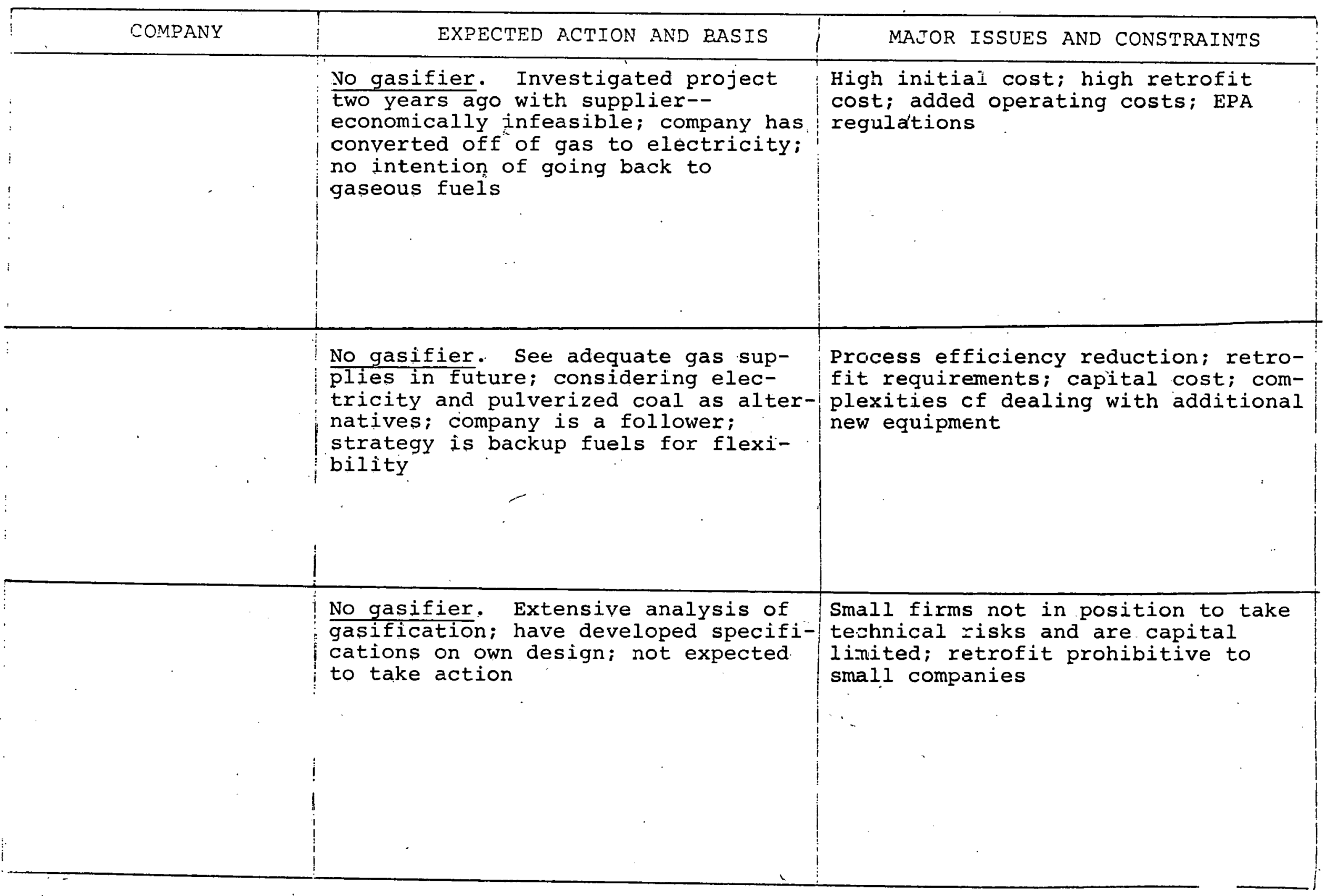




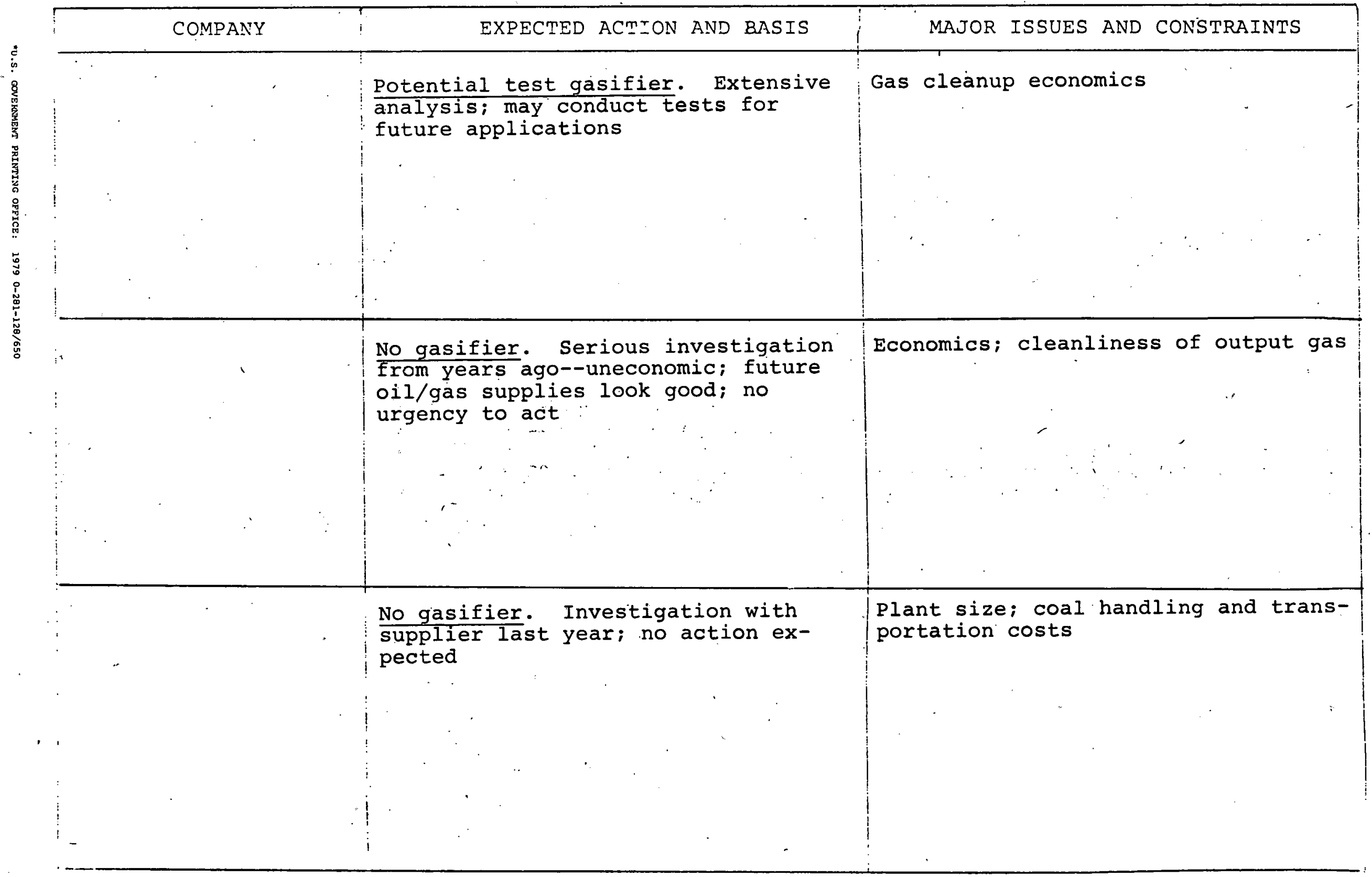

